\title{
The role of antibody in renal allograft rejection
}

Citation for published version (APA):

Majoor, G. D. (1981). The role of antibody in renal allograft rejection. [Doctoral Thesis, Maastricht University]. Rijksuniversiteit Limburg. https://doi.org/10.26481/dis.19810410gm

Document status and date:

Published: 01/01/1981

DOI:

10.26481/dis.19810410gm

Document Version:

Publisher's PDF, also known as Version of record

\section{Please check the document version of this publication:}

- A submitted manuscript is the version of the article upon submission and before peer-review. There can be important differences between the submitted version and the official published version of record.

People interested in the research are advised to contact the author for the final version of the publication, or visit the DOI to the publisher's website.

- The final author version and the galley proof are versions of the publication after peer review.

- The final published version features the final layout of the paper including the volume, issue and page numbers.

Link to publication

\footnotetext{
General rights rights.

- You may freely distribute the URL identifying the publication in the public portal. please follow below link for the End User Agreement:

www.umlib.nl/taverne-license

Take down policy

If you believe that this document breaches copyright please contact us at:

repository@maastrichtuniversity.nl

providing details and we will investigate your claim.
}

Copyright and moral rights for the publications made accessible in the public portal are retained by the authors and/or other copyright owners and it is a condition of accessing publications that users recognise and abide by the legal requirements associated with these

- Users may download and print one copy of any publication from the public portal for the purpose of private study or research.

- You may not further distribute the material or use it for any profit-making activity or commercial gain

If the publication is distributed under the terms of Article $25 \mathrm{fa}$ of the Dutch Copyright Act, indicated by the "Taverne" license above, 


\title{
THE ROLE OF ANTIBODY IN RENAL ALLOGRAFT REJECTION
}

\author{
P R OEFS CHR IFT
}

TER VERKRIJGING VAN DE GRAAD VAN DOCTOR IN DE GENEESKUNDE AAN DE RIJKSUNIVERSITEIT LIMBURG TE MAASTRICHT, OP GEZAG VAN DE RECTOR MAGNIFICUS PROF. DR. W. H. F. W. WIJNEN, HOOGLERAAR IN DE FAKULTEIT DER GENEESKUNDE, VOLGENS HET BESLUIT VAN HET COLLEGE VAN DEKANEN IN HET OPENBAAR TE VERDEDIGEN IN DE AULA VAN DE UNIVERSITEIT OP VRIJDAG 10 APRIL 1981 OM 16.00 UUR

door

GERARDUS DANIËL MAJOOR geboren te Voorburg (Z.H.) in 1947

MICHIELS - TONGEREN - BELGIË - 1981 
PROMOTOR: PROF. DR. P. J. C. VAN BREDA VRIESMAN

REFERENTEN: PROF. DR. C. P. A. VAN BOVEN

PROF. DR. P. J. HOEDEMAEKER

PROF. DR. I. J. VAN ROOD 
Aan mijn ouders

Voor Annewies, Daan en Ineke 


\section{Ahbreviations}

Names of rat strains have been abbreviated according to Festing, M., and Staats, J. : Standardized nomenclature for inbred strains of rats. Transplantation $16: 221,1973$.

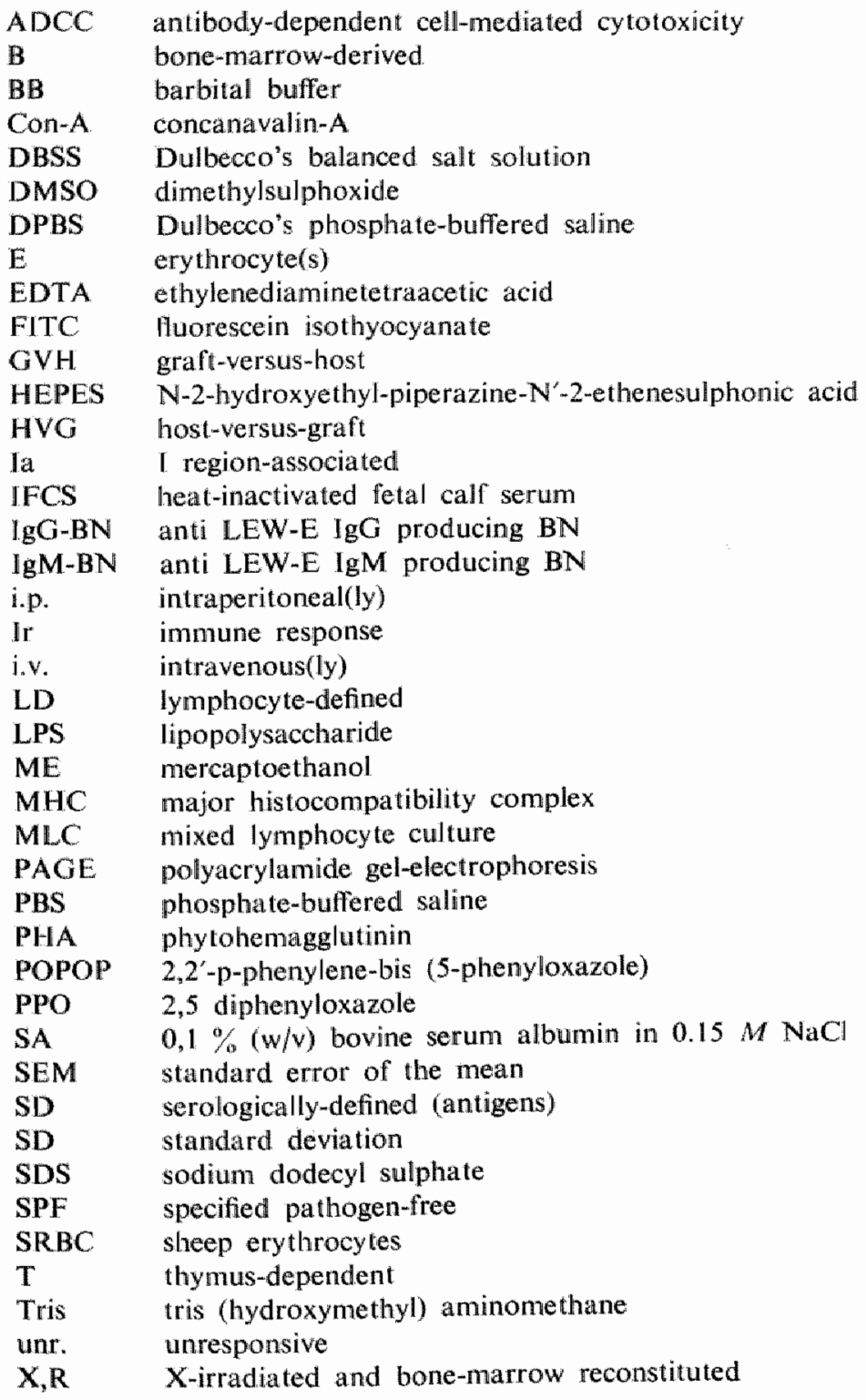


This study was performed as a joined effort of the Departments of Pathology and Immunology of the University of Limburg; all of the work was performed under supervision of Prof. Dr. P. J. C. van Breda Vriesman.

The majority of the laboratory experiments were performed with the expert technical assistance of Ms. M.-J. W. H. van de Gaar. Her skillfull thand can also be recognized in the figures presented in this thesis.

Ms. L. F. M. Vlek introduced the author to the practice of immunochemistry and prepared many of the immunological reagents used, often in cooperation with Ms. M. E. R. Henfling. Histological sections were prepared by Mrs. P. F. A. M. Palm-Storms and H. van Rie. Photographs were prepared with devotion by A. C. van der Gugten.

Renal transplantations were performed by Ms. L. van Grieken, Ms. M. J. Bisscheroux and $\mathbf{J}$. J. van Dongen. Skin transplantations and thoracic duct cannulations were executed by E. van Dam. Fine care for the experimental animals was taken by the staff of the Department for Experimental Animal Services. We are indebted to Dr. E. Günther (Max Planck Institut für Immunbiologie, Freiburg, F.R.G.) for his help with some of the immunogenetical studies.

As a consequence of his advices some statistical calculations had to be performed by A. Muytjens. The manuscript was typed by Mrs. I. van Wunnik and Mrs. M. G. P. Peters-Vanderschuren.

Financial support for the costs of printing was received from the Nier Stichting Nederland. 


\section{CONTENTS}

I. INTRODUCTION

1 General introduction . . . . . . . . 13

2 Design of the study . . . . . . . . . 15

References. . . . . . . . . 18

II. THE HISTOCOMPATIBILITY SYSTEMS OF THE RAT

1 Introduction . . . . . . . . . . 23

2 The major histocompatibility system of the rat . . 27

3 Tissue distribution of major and minor alloantigenic systems . . . . . . . . . . . 28

3.1 Erythrocyte-associated alloantigens . . . . 28

3.2 Lymphocyte-associated alloantigens. . . . 29

3.3 Organ-specific alloantigenic systems . . . . 30

4 Summary . . . . . . . . . . . . . 32

References . . . . . . . . . . 33

III. MATERIALS AND METHODS

1 Rats. . . . . . . . . . . . 40

2 Renal transplantation . . . . . . . . 40

3 Thoracic duct cannulation . . . . . . . 41

4 Media . . . . . . . . . . . 41

5 X-irradiation . . . . . . . . . . 42

6 Isotope labelling . . . . . . . . . . 42

6.1 Cells . . . . . . . . . . . . . . 42

6.2 Immunoglobulins . . . . . . . . 43

7 Cell suspensions . . . . . . . . . . . . 43

7.1 Erythrocytes . . . . . . . . . 43

7.2 Lymphoid cells . . . . . . . . . 46

7.2.1 T lymphocyte purification. . . . . . 47

7.3 Elimination of erythrocytes . . . . . . 48 
8 Lymphoblasts . . . . . . . . 48

8.1 Lectin-stimulation of lymphocytes . . . . 48

8.2 Purification of lymphoblasts . . . . . . . 49

9 Mixed lymphocyte culture (MLC) . . . . . 50

10 Cell-mediated cytotoxicity . . . . . . . 50

11 Antibody-dependent complement-mediated cytotoxicity 51

12 Hemagglutination. . . . . . . . . . . . . 52

12.1 Alloantisera . . . . . . . . . . > 52

12.2 Xenoantisera. . . . . . . . . 54

13 Xenoantibodies. . . . . . . . . 55

13.1 Antibodies for immunohistochemistry . . . 55

13.2 Antisera for erythrocyte purification . . . 57

13.3 Antibodies for indirect hemagglutination assays . 57

14 Rat IgG . . . . . . . . . . . 58

15 Histology and immunofluorescence . . . . . 58

16 Statistics . . . . . . . . . 59

References . . . . . . . . . . 60

IV. HUMORAL RESPONSIVENESS TO

ALLOGENEIC ERYTHROCYTES

I Introduction . . . . . . . . . . 63

2 On the immunogenicity of LEW-E for BN rats . . 63

2.1 The effect of age of the recipient and of antigen dose administered . . . . . . . 63

2.2 The kinetics of alloantibody responses . . . 66

2.3 Specificity of BN anti LEW-E antibodies . . . 68

3 Restricted immunogenicity of allogeneic erythrocytes . 70

4 Restricted responsiveness to allogeneic erythrocytes . 72

5 Discussion . . . . . . . . . 72

6 Summary . . . . . . . . . . . . . 78

References . . . . . . . . . . 79

V. ON THE MECHANISM OF MAINTENANCE OF UNRESPONSIVENESS BY HIGH DOSES OF LEW-E

1 Introduction . . . . . . . . . . . 82 
2 Specificity of unresponsiveness . . . . . . 85

3 The presence or absence of antigen-antibody complexes 87

4 The presence or absence of humoral suppressor factors $\quad 89$

5 Nature of the unresponsiveness . . . . . 90

6 Discussion . . . . . . . . . . . 96

7 Summary . . . . . . . . . . . . . 98

References . . . . . . . . . . . 99

VI. THE EFFECT OF AN ESTABLISHED ANTI LEW-E IgM ANTIBODY RESPONSE ON THE REJECTION OF LEW RENAL

GRAFTS BY BN RATS

1 Introduction . . . . . . . . . . 103

2 Experimental protocol. . . . . . . . 104

3 Survival of LEW renal grafts in IgM-BN hosts . . . 105

4 Immunopathology of LEW kidneys rejected by IgM-BN hosts . . . . . . . . . 106

5 Cytotoxic $\mathrm{T}$ cell response of IgM-BN rats to LEW renal grafts . . . . . . . . 112

6 Alloantibody response of IgM-BN rats to LEW renal grafts... . . . . . 114

7 Binding of BN anti LEW-E IgM antibodies to LEW renal grafts. . . . . . . 117

8 Effect of BN anti LEW-E IgM antibodies on the recirculation of LEW lymphocytes . . . . . . . 118

9 Discussion . . . . . . . . . 120

10 Summary . . . . . . . . . . 123

References . . . . . . . . . . 124

VII. THE EFFECT OF AN ESTABLISHED ANTI LEW-E IgG ANTIBODY RESPONSE ON THE REIECTION OF LEW RENAL

GRAFTS BY BN RATS

1 Introduction . . . . . . . . . . 129

2 Experimental protocol . . . . . . . . 129

3 Survival of LEW renal grafts in IgG-BN hosts . . 129 
4 Immunopathology of LEW kidneys rejected by IgG-BN hosts

5 Cytotoxic $\mathrm{T}$ cell response of IgG-BN rats to LEW renal grafts

6 Binding of BN anti LEW-E IgG antibodies to LEW renal grafts

7 Alloantibody response of IgG-BN rats to LEW renal grafts

8 Discussion

9 Summary References

VIII. THE EFFECT OF HUMORAL UNRESPONSIVENESS TO LEW-E ON THE REIECTION OF LEW RENAL GRAFTS BY BN RATS

1 Introduction . . . . . . . . . . 155

2 Experimental protocoi . . . . . . . . 155

3 Anti LEW immune responses in LEW-E unr. BN rats. 155

4 Survival of LEW and WISTOR renal allografts in LEW-E unr. BN hosts . . . . . . . . . 157

5 Alloantibody responses of LEW-E unr. BN rats to LEW renal grafts . . . . . . . . . . 157

6 Cellular immune responses of LEW-E unr. BN rats to LEW renal grafts . . . . . . . . . 162

7 Induction of acute rejection of a LEW kidney residing in a LEW-E unr. BN rat . . . . . . . 164

8 Discussion . . . . . . . . . 164

9 Summary . . . . . . . . . . . 168

References . . . . . . . . . . 169

SUMMARY . . . . . . . . . . . 171

SAMENVATTING . . . . . . . . . . . . . 175 


\section{INTRODUCTION}

\section{General introduction}

Exchange of skin and vascularized allografts from one mammal to another within one species will almost invariably lead to rejection of the transplanted tissue. Rejection of vascularized grafts can be defined as termination of graft function and viability secondary to vascular damage of the graft causing destruction of its architecture. Graft destruction is mediated by specific immune effector mechanisms of the host against donor antigens which in turn activate aspecific inflammatory reactions. The specific immunological component of the host-versus-graft (HVG) reaction consists of two main effector arches : cellular and humoral defense mechanisms.

The cellular immune response is usually considered to be mediated by cytotoxic $\mathrm{T}$ lymphocytes which can be shown in vitro to kill target cells of donor origin specifically $(10,18)$. In vivo, cytotoxic $\mathrm{T}$ cells are generated in regional lymph nodes after peripheral sensitization of the host (e.g. by a skin allograft (13)) and are demonstrable in the central lymphoid organs after transplantation of a vasculary anastomosed (vascularized) organ transplant $(5,21)$. Immune responses elicited in central lymphoid organs by vascularized allografts may be amplified by a graft-versus-host (GVH) reaction brought about by recirculating and mobile "passenger" leukocytes that come out of a grafted organ (46). Activation of cytotoxic $\mathrm{T}$ lymphocytes may be promoted by the activation of helper $\mathrm{T}$ lymphocytes $(9,40,41)$ and counteracted by the generation of suppressor $T$ lymphocytes $(51,54)$. Suppressor $T$ cells have been shown to control the magnitude of $\mathrm{HVG}$ cellular immune responses (22). Participation of cytotoxic T lymphocytes in skin allograft rejection has been demonstrated in vivo since passive transfer of specifically sensitized $\mathrm{T}$ lymphocytes caused accelerated rejection of skin allografts in mice (12). Whether acceleration of rejection is brought about by a direct cytotoxic 
effect of these 'killer' $T$ lymphocytes or mediated by lymphokines released secondary to the interaction between sensitized $T$ lymphocytes and target cells is not known $(17,23)$. Lymphokines may injure the graft directly $(23,33,44)$ or by means of activating host-derived macrophages locally (37). Although specifically sensitized $T$ lymphocytes of host origin are present in rejecting rat organ allografts $(50,52)$ this does not mean that first set rejection of vascularized allografts is therefore mediated by these T lymphocytes. T cell depletion of rats by means of thymectomy, irradiation and bone marrow reconstitution prevented the rejection of subsequently inserted cardiac allografts (30). Obviously, this experiment did not prove involvement of cytotoxic $T$ lymphocytes in cardiac allograft rejection since helper $T$ lymphocytes may participate in establishing anti donor humoral immune responses.

Although allografts elicit antibodies in the recipient the role of these antibodies in first set allograft rejection is not clear $(6,16)$. Antibodies elicited by grafted tissue have been operationally defined as being directed against donor Class I, Class II, and organ specific antigens (See Chapter II); additional categories will undoubtedly be found in the near future $(32,38)$. Conceptually, host antibodies bound to graft alloantigens may protect the graft against the action of cytotoxic $T$ cells, e.g. by blocking antigenic bindings sites for these cells $(14,15,28)$ or alternatively may protect the graft by 'capping' antigens present on the surface of the donor cells which may subsequently be shed into the 'milieu interieur' $(3,36,48)$. On the other hand, antibodies may injure the graft by binding and activating non-specific inflammatory effector systems like complement and antibody-dependent cytotoxic cells including leukocytes and macrophages (ADCC) (55). Adherence of phagocytes to target cells is greatly facilitated by, and recognition by leukocytes effective in ADCC is completely dependent on opsonization of the target antigens by antibody. As indicated above for the cellular immune response, activation of these aspecific effector mechanisms may be accompanied by the release of inflammatory mediators which may add to or cause target cell injury $(4,55)$. Whether alloantibody bound to a target cell will protect against injury or damage the target cell is determined by a number of factors including the antigen density on the target cell surface $(6,25,29,34)$, the immunoglobulin class in which the 
antibodies reside $(31,45,47)$ and the affinity of the antibody for the target antigen $(6)$.

The humoral and the cellular arch of the HVG response are not acting independently from each other. For example, in the afferent. arch of the immune response a regulatory balance has been suggested to exist favoring the development of either humoral or cellular immunity (7), which has been suggested to be controlled by suppressor $T$ cells $(42,43)$. In the efferent phase of the HVG response both humoral and cellular immunity may act additively in the rejection of allografts if each system focusses on different donor antigens $(11,16)$. Synergism between both effector arches of immunity has been suggested by the finding that killing of donor target cells by specific cytotoxic $T$ cells was enhanced by opsonization of the target cells with antibody (18).

To study the interaction of immunological mechanisms effective in graft rejection we have selected an allo-transplantation model that permitted us to interfere with one circumscribed part of the HVG response elicited by vascularized grafts. The rationale for the model used and the selection of the part of HVG response to. be manipulated will be outlined below.

\section{Design of the study}

The aim of this thesis was to elucidate the role of host sensitization to Class I alloantigens in the rejection of vascularized allografts. This question derived from clinical observations which suggested that matching of the recipient of a renal allograft for HLA-A and $\mathrm{B}$ (Class $\mathrm{I}$ ) antigens enhanced renal allograft survival $(\ell, 8$, $24,35)$ with the restriction added subsequently that this observation was valid only when Class II histocompatibility was present als well $(39,53)$. These observations suggested that an immune response to HLA-A and B antigens was deleterious to renal allografts, but these clinical observations in immuno-suppressed patients did not indicate how reduced survival was brought about. This may conceptually be explained in two fashions provided recipients sensitized prior to transplantation to Class 1 alloantigens of the donor are left out of consideration :

1. HLA-A and B alloantigens residing in the graft serve both as immunogens and as targets to the host immune response. 
2. HLA-A and B alloantigens of the graft serve as target antigens only. This hypothesis derives from in vitro work which indicates that sensitization of the host to Class I antigens depends on the presence of Class II alloantigens but that the cytotoxic response elicited is directed against Class I alloantigens only (2).

In order to rule out a contribution of Class II alloantigens on the afferent immune response of the host, recipients of vascularized allografts had to be sensitized a priori with Class I alloantigens in order to study the effect of an anti Class I immune response on the rejection of vascularized allografts.

To study the effect of recipient sensitization to Class I alloantigens on vaseularized allograft rejection the model of kidney transplantation in the rat was choosen for several reasons. First, the kidney is a useful target organ in studying allograft rejection since graft function can be conveniently monitored by measuring the serum urea or creatinine concentration. Second, the rat is an opportune animal to work with since the technique of kidney transplantation is standardized (26) and because inbred strains are available. In this study the LEW to BN combination was used since LEW kidneys lack a tubular basement membrane alloantigenic system which in the BN to LEW combination contributes to rejection $(20,27)$. In addition congenic strains of LEW rats have recently been developed $(19,49)$ allowing a more precise analysis of the histocompatibility barrier crossed. In Chapter II the alloantigenic systems known in the rat and relevant to this study have been reviewed in the context of the current knowledge of the immunogenetics of this species; these data have been compared to those of man and mice. The third reason why rats were worked with resides in the fact that rodent erythrocytes express Class I alloantigens on their surface but are void of Class II antigens (56). Therefore, procedures were developed to obtain highly purified rat erythrocytes (See Chapter III); next allogeneic hosts were sensitized with these erythrocytes varying both the number of the erythrocytes and the age of the recipients in order to elicit both responsiveness and unresponsiveness to donor erythrocytes. These studies are described in Chapter IV and show that both responsiveness in terms of IgM and IgG alloantibody as well as non-responsiveness can be reproducibly elicited. The mechanism(s) that might be operative in the maintenance of unresponsiveness are discussed and subjected 
to experimental analysis in Chapter V. Finally the effect of sensitization of recipients of renal allografts with donor strain erythrocytes on graft survival was studied. For this purpose sensitization protocols were selected yielding IgM antibody (Chapter VI), IgG antibody (Chapter VII) or non-responsiveness (Chapter VIII) to donor erythrocytes. Subsequently donor kidneys were inserted into these sensitized recipients; the renal allograft survival was measured and attempts were made to elucidate the mechanisms of rejection or: alternatively the failure of rejection operative in each experimental group. 


\section{References}

1 Ascher, N. L.s Simmons, R. L., Fryd, D., Noreen, H., and NAJarian, J. S. : Effects of HLA-A and B matching on success of cadaver grafts at a single center. Transplantation $28: 172,1979$.

2 BACH, F. H., BACH, M. L., and SONDEL, P. M. : Differential function of major histocompatibility complex antigens in T-lymphocyte activation. Nature 259: 273, 1973.

3 BALINT, J. Ir., and FeLDMAN, I. D.: Circulating immune complexes in rats grafted with allogeneic tissues. Transplantation $27: 437,1979$.

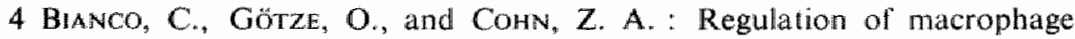
migration by products of the complement system. Proc. Natl. Acad. Sci. USA 76: 888, 1979.

5 BuEsecker, J. L. : Cellular and humoral immunity after allogeneic transplantation in the rat. I. Cellular and humoral immunity as measured by a ${ }^{\text {s }} \mathrm{Cr}$ cytoloxicity assay after allogeneic tumor and renal transplantation. Transplantation 15:298, 1973.

6 BRlda VRiesman, P. J. C. VAm, SWANen-Sierag, L., and Vlek, L. F. M. : Cytotoxic and enhancing properties of early $\gamma \mathrm{M}$ alloantibodies elicited by first set renall allografts. Transplantation $20: 385,1975$.

7 Bretcher, P. A. : Hypothesis on the control between cell-mediated, IgM and IgG immunity. Cell. Immmol, 13: 171, 1974.

8 Broyer, M., Gagnadoux, M. F., Beurton, D., Pascal, B., Busson, M., and Hors, J. : Importance of HLA-A, B matching in kidney transplantation in children. Transplantation 30:310, 1980.

9 Cantor, H., and Boyse, E. A. : Functional subclasses of T lymphocytes bearing different Ly antigens. II. Cooperation between subclasses of Ly cells in the generation of killer activity. J. Exp. Med. 141: 1390, 1975.

10 Cerottin, J.-C., Nordin, A. A., and Brunner, K. T. : Cellular and humoral response to transplantation antigens. J. Exp. Med. 134:553, 1971.

11 Dennert, G., and HYMAN, R.: The importance of the serologically detectable histocompatibility antigens in the induction and effector step of cell-mediated lysis. Eur. J. Immunol. $7: 251,1977$.

12. Eichwald, E. J., Craven, C. M., Spellman, C., and Dolbero, M. L. : The cell type mediating hyperacute rejection of allogeneic mouse skin grafts. Cell. Immunol. $33: 219,1979$.

13 Emam, M., Barstad, R., and Eichwald, E. J. : Transfer of cell-mediated hyperacute rejection reaction. The role of active sensitization. Cell. Immunol. $49: 426,1980$.

14 Epstein, S. L., OzATO, K., and SACHS, D. H. : Blocking of allogeneic 
cell-mediated lympholysis by monoclonal antibodies to H-2 antigens. J. Immunol. I25: 129, 1980.

15 Feigherr, C. F,, and Stastny, P.: Cell-mediated cytotoxicity against HLA-D-region products expressed in monocytes and B-lymphocytes. 1. Blocking by unlabelled cells and inthibition by antisera. Immanogenetics $10: 31,1980$.

16 Gallico, G. G, and MAson, D. W. : Correlation between an abberant serological response to transplantation antigens and renal allograft enhancement in allogeneic recipients. Transplantation $26: 46,1978$.

17 Gately, M. K., Mayer, M. M., and Henney, C. S. : Effect of antilymphocytotoxin on cell-mediated immunity. Cell. Immunol. 27:82, 1976.

18 Govaerts, A. : Cellular antibodies in kidney homotransplantation. $J$. Inmunol. $85: 516,1960$.

19 Günther, E., STark, O., and KoCH, C. : Genetic definition of \| regiondetermined antigens of the rat major histocompatibility complex. Eur. J. Immunol, $8: 206,1978$.

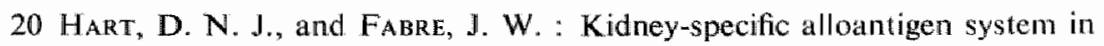
the rat. J. Exp. Med. 151: 651, 1980.

21 HÄYRY, P., VON WILlEbrand, E., and Soors, A. : In situ effector mechanisms in rat kidney allograft rejection. IIII. Kinetics of the inflammatory response and generation of donor-directed killer cells. Scand. J. $\mathrm{lm}$ mumol. $10: 95,1979$.

22 Hendry, W. S., Tilney, N. L., Baldwin, W. M. III, Graves, M. I., Milford, E., Strom, T. B., and Carpenter, C. B. : Transfer of specific unresponsiveness to organ allografts by thymocyltes. J. Exp. Med. 149: 1042, 1979.

23 Hiserodt, J. C., and Granger, G. A. : Inhibition of human lymphocylemediated mitogen-induced cytotoxicity of murine L- $929 \mathrm{cells}$ by heterologous anti-human lymphotoxin antisera in vitro. $\%$. Immmol. 119 : $374,1977$.

24 HoOFF, J. P. VAN, HOOFF-EIJKenhoOM, Y. E. A. VAN, KAlF, M. W., GRAEFF, J. de, and ROOD, J. J. VAN: Kidney graft survival, clinical course and HLA-A, B, and D matching in 208 patients transplanted in one center. Transplamt. Proc. H: 1291, 1979.

25 KeANer, M., MCPHAll, S, Jlodouin, C.-A., and Richter, M.: The antibody-dependent cell-mediated cytotoxic reaction. II. The effect of the concentration of anti-target cell antibodies on the identity of the human effector cells. Immunology $40: 205,1980$.

26 LEE, S. : An improved technique of renal transplantation in the rat. Surgery $61: 771,1967$. 
27 LehmaN, D. H., LeE, S., WILson, C. B.; and Dixon, F. J. : Induction of antitubular basement membrane antibodies in rats by renal transplantation. Transplantation $17: 429,1974$.

28 LINDAHL, K. F., and LEMKE, H. : Inhibition of killer-target cell interaction by monoclonal anti-H-2 antibodies. Eur. J. Immunol.9: 526, 1979.

29 Linscotr, W. D. : Effect of cell surface antigen density on immunological enhancement. Nature 270: 824, 1970.

30 MaclenNan, I.; Baldwin, W. M., and Tilney, N. L.: The effect of T-cell depletion on host responses to organ allografts. Transplant. Proc. 11: 1435, 1979.

31 Medgyesi, G. A., Füst, G., Gergely, J., and Bazin, H. : Classes and subclasses of rat immunoglobullins: interaction with the complement system and with staphylococcal protein A. Immunochemistry 15: $125,1978$.

32 Moraes, J. R., and Stastny, P. : A new antigen system expressed in human endothelial cells. $J$. Clin. Invest. $60: 449,1977$.

33 NAMBA, Y., and WAKSMAN, B. H. : Regulatory substances produced by lymphocytes. III. Evidence that lymphotoxin and proliferation inhibitory factor are identical and different from the inhibitor of DNA synthesis. J. Immunol. I16: 1140, 1976.

34 Northoff, H., KLuge, A., and Resch, K. : Antibody dependent cellular cytotoxicity (ADCC) against human erythrocytes, mediated by blood group alloantibodies: A model for the role of antigen density in target cell lysis. $Z$. Immun.-Forsch. $154: 15,1978$.

35 Oriol, R., Opelz, G., Chun, C., and Terasaki, P. I. : Combined effects of HLA matching and age in renal transplantation. Transplantation 29: 125, 1980.

36 Palosuo, T., Kano, K., Anthone, S., Gerbasi, J. R., and Milorom, F. : Circulating immune complexes after kidney transplantation. Transplantation $21: 312,1976$.

37 Pantalone, R., and Page, R. C. : Enzyme production and secretion by lymphokine-activated macrophages. I. Reticuloendorhel. Soc. 21 : 343 , 1977.

38 Paul, L. C., Stuffers-Heiman, M., Es, L. A. Van, and Graeff, J. DE: Antibodies directed against brush border antigens of proximal tubules in renal allograft recipients. Clim. Immunol. Immunopathol. $14: 238$, 1979.

39 Persinn, G. G., Lelluwen, A. A. van, Hoogeboom, J., Gabb, B. W., NAGTEGAal, A., and ROOD, J. J. VAN: Matching for HLA-antigens of A, B and DR loci in renal iransplantation by Eurotransplant. Lancet I: $1278,1978$. 
40 Pilarski, L. M. : A requirement for antigen specific helper $T$ cells in the generation of cytotoxic $T$ cells from thymocyte precursors. $J$. Exp. Med. 145: 709, 1977.

41 Peizenmaier, K., Delzeit, R., Röllinghoff, M., and Waginer, H: $\mathrm{T}-\mathrm{T}$ cell interactions during in vitro cytotoxic $\mathrm{T}$ lymphocyte responses. III. Antigen-specific $T$ helper cells release non-specific mediator(s) able to help induction of $\mathrm{H}-2$ restricted cy totoxic $\mathrm{T}$ lymphocyte responses across cell-impermeable menbranes. Eur. J. Immunol. 10:577, 1980.

42 Ramshaw, I. A., Bretscher, P. A., and Parish, C. R. : Regulation of the immune response. I. Suppression of delayed-type hypersensitivity by T-cells from mice expressing humoral immunity. Eur. J. Immunol. 6 : $674,1976$.

43 Ramshaw, I. A., Woodsworth, M., Wright, K., and McKenzie, I. F. C. : Induction of suppressor $T$ cells of antibody formation under conditions that preferentially simulate DTH. J. Immunol. $125: 197,1980$.

44 Russell, S. W., Rosenau, W., Goldberg, M. L., and Kumtromi, G. : Purification of human lymphotoxin. J. Immunol. 109 : 784, 1972.

45 RuszKIEWICZ, M. : Complement-activating properties of some rat alloantibodies. Transplantation $20: 227,1975$.

46 Schilfgarde, R. Van, Hermans, P., Terpstra, J. L., and Breda VriesMAN, P. J. C. VAN : Role of mobile passenger lymphocytes in the rejection of renal and cardiac allografts in the rat. Tramsplantation 29 : $209,1980$.

47 Shaw, S., PiChler, W. J., and Nelsow, D. L. : Fe receptors on human $T$ lymphocytes. III. Characterization of subpopulations involved in cell-mediated lympholysis and antibody-dependent cellular cytotoxicity. J. Immunol. $122: 599,1979$.

48 Smith, M. D., Verroust, P. J., Griffin, P. J. A., and Salaman, J. R. : The detection of circulating immune complexes in renal transplant patients. Clim. Exp. Inmunol. 39 : 141, 1980.

49 Stark, O., Günther, E., Kohoutová, M., and Vojcik, L. : Genetic recombination in the major histocompatibility complex (H-1, Ag-B) of the rat. Immunogenetics 5: $\mathbb{1 8 3 , 1 9 7 7 .}$

50 Strom, T. B., Tulney, N. Lu, Paradysz, J. M., Bancewllcz, J., and Carpenter, C. B. : Cellular components of allograft rejection: identity, specificity and cytotoxic function of cells infiltrating acutely rejecting allografts. J. Immunol. 118: 2020, 1977.

51 TAGart, V. B., Thomas, W. R., and Asherson, G. L. : Suppressor T cells which block the induction of cytotoxic T cells in vivo. Jmmunology 34 : $1109,1978$. 
52 TILney, N. L., Strom, T. B., MacPherson, S. G., and Carpenter, C. B. : Surface properties and functional characteristics of infltrating cells harvested from acutely rejecting cardiac allografts in inbred rats. Transplanfotion $20: 323,1975$.

53 TiNG, A., and Morris, P. J. : Matching for B-cell antigens of the HLA-DR series in cadaver renal transplantation. Lancet $I: 575,1978$.

54 Wagner, H., Starzinski-Powitz, A., Phizenmaier, K., and RöllingMOFF, M. : Regulation of $T$ cell-mediated cytotoxic allograft responses. I. Evidence for antigen-specific suppressor T cells. Eur. J. Immunol. 6 : $873,1976$.

55 WAKSMAN, B. H.: Immunoglobulins and lymphokines as mediators of inflammatory cell mobilization and target cell killing. Cell. Inmumol. 27 : $309,1976$.

56 Wellsh, K. I., Burgos, H., and BATCHELOR, J. R. : The immune response to allogeneic rat platelets; $\mathrm{Ag} \cdot \mathrm{B}$ antigen in matrix form lacking Ia. Eur. J. Immunol. $7: 267,1977$. 


\section{THE HISTOCOMPATIBILITY SYSTEMS \\ OF THE RAT}

\section{1 introduction}

Molecules found in a living being are synthesized according to instructions given by the bearers of that creature's hereditary properties : the genes. Many molecules of one kind e.g. albumin molecules are largely identical within one species, indicating that in most individuals of that species albumin molecules are synthesized according to information delivered by identical genes. Alternatively, two or more different forms of a gene exist (alleles) that may give rise to the existance of phenotypically different molecules among individuals of one species. The presence of two or more alleles at one locus is called genetic polymorphism. The more allelic forms of a certain gene exist, the larger the variability in the phenotypic forms of the molecule encoded by that gene will be. This situation applies particularly to a number of glycoproteins present on the surface of somatic cells, whose polymorphism is illustrated by exchanging skin grafts e.g. between two wild rats : almost certainly each recipient will reject its graft due to the recognition of foreign glycoproteins on the surface of donor cells (transplantation antigens) by the recipient's immune system. The term 'transplantation antigens' has been used here as an operational definition of the alloantigenic disparity between the recipient and the graft leading to graft rejection: all alloantigenic incompatibilities including those that do not lead to graft rejection have been referred to as histocompatibility antigens: By continued mating of brothers and sisters for 20 or more generations the histocompatibility genotype of the animals can be stabilized. Individuals from the inbred rat strain established in this fashion will be mutually histocompatible as can be demonstrated by indefinite acceptance of skin grafts exchanged between members of this inbred strain.

Although probably all eukaryotic somatic cells of one individual contain all genes available to that individual, every cell does not 
synthesize all molecules. How this restriction of gene expression is brought about is unknown but this mechanism accounts for the occurrance of differentiation antigens : antigens expressed only on some cell- or tissue types. Expression of differentiation antigens may even vary among representatives of different inbred strains and can than be defined as histocompatibility antigens as well.

Using mice derived from two histoincompatible inbred strains it was noticed a few decades ago that the strong histocompatibility barrier causing vigorous rejection of allogeneic tumour grafts was possibly represented by one alloantigenic system (Histocompatibility antigen 2 or $\mathrm{H}-2$ ) (27). The gene (or genes) coding for this system could be mapped to the IXth gene linkage group of mouse (28). Later it became apparent that more genes were involved in the determination of a strong histocompatibility barrier, and because these genes were linked to the gene coding for $\mathrm{H}-2$ this chromosomal region was termed the $\mathrm{H}-2$ complex. The IXth gene linkage group the $\mathrm{H}-2$ complex was associated with was subsequently assigned to chromosome number 17 of mouse (56).

The genetic analysis of the H-2 complex has been greatly facilitated by the development of congenic inbred mouse strains (78). Animals from congenic strains are genotypically identical with the exception of only one well-defined part of the genome, e.g. (a part of) the H-2 complex. Using congenic mouse strains skin grafts could be exchanged between mice being identical for the $\mathrm{H}-2$ complex but different for one non-H-2 locus coding for surface determinants. In these combinations skin grafts were often rejected albeit in a delayed fashion when compared to skin graft rejection over a $\mathrm{H}-2$ incompatibility barrier (9). Thus, it was concluded that the $\mathrm{H}-2$ complex played a major role in graft rejection (and could be designated major histocompatibility complex") whereas non-H-2 loci only played a minor role in this process (and could be referred to as 'minor histocompatibility loci') (9). Apart from this functional dissociation a number of other differences between 'major' and 'minor' histocompatibility systems emerged, including: 1) the extreme genetic polymorphism and the complex genetic structure of the $\mathrm{MHC}$ versus the relative simplicity of minor systems (often having two alleles only); 2) the strong effect of MHC disparity on MLR and GHV reactions versus the weak effect or absence of any effect of minor systems 
on these cellular reactions; and 3) the difficulty to tolerize a host for $\mathrm{MHC}$ antigens or to suppress its immune response to MHC antigens as compared to the relative ease to achieve tolerization or immunosuppression to minor alloantigens (45).

Major histocompatibility systems have been identified in all avian and mammalian species thus far examined. In lower animals indications for the existance of an $\mathrm{MHC}$ analogue have been found in Xenopus laevis (Amphibia) (8). Since most knowledge has accumulated on the structure and function of the $\mathrm{H}-2$ complex of mouse it will be described in more detail below although only as far as relevant to allow comparison to the MHC of man (called HLA system) and rat (denoted as RT1 complex).

The HLA system was mapped to human chromosome number $6(20)$ and the $\mathrm{H}-2$ complex to chromosome number 17 of mouse (56). The RTI complex forms linkage group VIII of rat (65); the respective chromosome has not yet been identified. Within the MHC of all three species a number of regions has been recognized by separating them by crossing-over; each region harbors at least one locus. In mouse 10 (sub-)regions have been identified; their sequence on chromosome 17 is probably $\mathbb{K}$, I-A, I-B, I-J, I-E/C, S, D/L, T. Four loci have been described in man (A, B, C, and DR) and three regions in rat (A, B, and C) (Fig. II. I).

\begin{tabular}{lcccc}
\hline Species & $\begin{array}{c}\text { MHC } \\
\text { nomenclature }\end{array}$ & $\begin{array}{c}\text { Linkage } \\
\text { group }\end{array}$ & $\begin{array}{c}\text { Chromosome } \\
\text { number }\end{array}$ & Regions \& Subregions \\
Rat & RT 1 & VIII & $?$ \\
Manse & H-2 & $\mathbb{I X}$ & 17
\end{tabular}

FIG. II.1. The MHC of rat, mouse and man ${ }^{2}$ ).

1) MHC (sub-) regions are presented in actual sequence but at arbitrary distances. Functional analogy is indicated by identical symbols.

- : Region harbors loci coding for Class 1 antigens.

口 : Region harbors loci coding for Class II antigens. 
Functionally analogous regions have been determined within the MHC of all three species. The classical histocompatibility antigens proved to be highly immunogenic in terms of eliciting antibody in allogeneic recipients and were therefore referred to as serologically defined (SD) antigens. We prefer the arbitrary but neutral designation Class I antigens (46). Class I antigens are coded for by the $\mathrm{MHC}$ regions $\mathrm{K}$ and $\mathrm{D}$ of mouse, $\mathrm{A}, \mathrm{B}$, and $\mathrm{C}$ in man and $A$ in rat. Apart from the histocompatibility antigens primarily known for their capacity to elicit alloantibodies another set of MHC-encoded histocompatibility antigens was found to be primarily involved in cellular immune reactions. Because these antigens were detected by means of mixed lymphocyte cultures they were called lymphocyte-defined (LD) antigens. However, since these antigens may also elicit alloantibodies this term is quite misleading; the use of the neutral denotation Class II antigens is more appropriate. Because these antigens were first discovered in the mouse, provisionally mapped to the I region and consequently called I region-associated (fa) antigens, they were also referred to in other species as la-like antigens. Most likely their analogues in man are encoded by the HLA-D region (DR) and in rat by the RTI. B region. In the mouse 5 subregions of the $\mathrm{H}-\mathrm{I}$ region have been distinguished but in $\operatorname{man}(71,86,88)$ and rat $(29,73,79)$ indications for the existance of only two Class II gene products were found thus far. Probably additional Class II gene products will be detected for reactivity of mammalian alloantibodies against MHC products with MHC products of other species suggests that $\mathrm{MHC}$ genes are well conserved during mammalian phylogeny $(2,4,5,25,67,77)$. Possibly, the structure of the MHC of man and rat may prove to be as complex as that of the mouse. This assumption is supported by the finding that the biochemical structure of histocompatibility antigens appears to be very similar among different mammalian species. Class I antigens are glycoproteins with a molecular weight of about $45.000-52.000$ including $\beta_{2}$-microglobulin with which it is found in association $(4,49,72,79)$. Class II antigens are built up by two glycoprotein chains called $\alpha$ and $\beta$; the molecular weight of the entire Class II molecule is about 25.000-35.000 $(4,72,79)$.

In this Chapter the histocompatibility antigens of the rat will be discussed in relation to what is known of the genes coding for 
these antigens. Emphasis has been put on histocompatibility alloantigens present on rat kidney, erythrocytes and lymphocytes since these are pertinent to our model of manipulation of renal allograft rejection. Consequently, antigens detectable by xenogeneic antibodies and autoantigens have been mentioned briefly or not at all. It should be emphasized that the knowledge of histocompatibility antigens and immunogenetics of the rat lags behind that of mice and man so that the picture given below can only be considered to be a temporary one.

\section{The major histocompatibility system of the rat}

In the rat 17 different MHC haplotypes have been described so far (24). Although intra-MHC crossing-over appears to be a rare event a few intra-MHC recombinants are available $(6,81,82)$. These recombinant haplotypes have revealed the existance of three separable regions within the $\mathrm{RT} \mathbb{1}$ complex that were denoted $\mathrm{A}, \mathrm{B}$, and $\mathrm{C}$ respectively $(35,82)$.

The RTI.A region comprises at least one locus coding for Class I major histocompatibility antigens $(6,35,81)$. Biochemical and immunological studies of Class I histocompatibility antigens have shown that two distinguishable Class I molecules exist within an inbred rat suggesting the presence of two loci coding for them $(4,60,80)$. As stated in the introduction Class I major histocompatibility antigens are probably present on the surface of all nucleated somatic cells. It is relevant to mention here that in contrast to other mammals like man, monkey, and dog Class I antigens are easily demonstrable in rodents on the surface of erythrocytes $(6,81)$; since HLA antigens have also been demonstrated on reticulocytes but not on mature erythrocytes $(66)$ the age of an erythrocyte may determine the presence or absence of Class I antigens on the erythrocyte surface in a given species. Apart from the immunogenic properties of these antigens presented on grafted tissues in terms of eliciting antibody responses in allogeneic recipients these Class I antigens have been shown in mouse to be the major target antigens for allo-sensitized cytotoxic $\mathrm{T}$ lymphocytes $(1,13,16)$.

The RTI.B region harbours at least one locus determining strong reactivity in MLC $(6,33)$. Strong reactivity may be mediated by 
recognition of RT1.B-encoded cell surface histocompatibility antigens on the stimulator cells and/or be controlled by genes linked to the RT1.B region (74). Apart from the possibility that genes controlling MLC reactivity map to the RTI.B region genes controlling humoral immune responsiveness (Ir genes $(23,26,32)$ ) to synthetic antigens have been shown to be linked to the RT1.B region $(3 l, 74)$. On the other hand, Ir genes that map outside the RTI complex have been discovered as well (39).

Analogous to the situation described for Class I antigens, Class II antigens from one inbred rat were shown to be separable in two biochemically different products $(79,80)$. Only one of these Class II molecules has been shown to be encoded by a gene mapping to the RTI.B region (33). In addition an alloantiserum has been raised detecting an RT1-associated Class II alloantigenic system using the RT1.A and RT1.B-compatible LEW and F344 rat strains (7). Identity of these serologically detected alloantigens and one of the two biochemically defined Class II products has not yet been demonstrated. Class II antigens have a restricted tissue distribution (34). Most relevant to our studies is their expression on B lymphocytes $(35,55)$ that may migrate out of a grafted kidney to the host's lymphoid organs and on renal endothelial cells (64). Next to their prominent function in the induction of immune responses against allogeneic histocompatibility antigens $(10,43)$ la-like antigens have been demonstrated in mouse (59, $85,90)$ and in man $(18,19,42)$ to be potential target antigens for cytotoxic T lymphocytes.

The RT1.C region has been defined recently $(47,82,83)$. As far as is known it harbours one or more loci coding for major histocompatibility antigens that induce weak allogeneic immune reactions. RTI.C-encoded alloantigens expressed on the surface of lymphocytes were demonstrable using both alloantibodies or cytotoxic T lymphocytes (30).

3 Tissue distribution of major and minor alloantigenic systems

\subsection{Erythrocyte-associated alloantigens}

Class I major histocompatibility antigens encoded by the RTI.A region are expressed on the surface of erythrocytes although 
RTI antigen density on the erythrocyte surface may vary from strain to strain (38). Next to these RTl alloantigens two erythrocyteassociated minor alloantigenic systems have been described in inbred rat strains : RT2 (formerly designated AgC or H-3) and RT3 (previously known as $\mathrm{AgD})(48,62,87)$. The RT2 locus has at least two alleles: $a$ and $b$; of the RT3 locus only one allele (a) has been found thus far. The other allele may be genetically 'empty' and not code for an erythrocyte-associated surface antigen (48). Another alloantigen has been described (AgS) the presence of which appears to be restricted to only few of the common inbred rat strains (48); the distribution of again a different alloantigenic system $(\mathrm{H}-2)$ has not been assessed in most of the commonly available rat strains (2l). These alloantigenic systems were not included in a survey of alloantigenic systems represented by the rat strains used in this study (Table II.1).

\subsection{Lymphocyte-associated alloantigens}

Class I major histocompatibility antigens encoded by the A region of the RTI complex are expressed on all (sub)sets of lymphocytes. Class Il antigens coded for by the RTI.B region are present on $B$ lymphocytes and may be present in a much lower antigendensity on (subsets of) $\mathrm{T}$ lymphocytes $(22,55,58)$. Both $\mathrm{B}$ and $\mathrm{T}$ lymphocytes may express RT1.C region-encoded antigens ( 30 ).

The RT2 and RT3-determined alloantigens described in Section 3.1 have been reported to be expressed on lymphoid cells as well $(6 /)$ but the tissue distribution of these minor alloantigenic systems has not been investigated in detail. Furthermore, antigens coded for or controlled by genes located on the male $Y$ chromosome (H-Y antigen(s)) have been suggested to be present on the surface of lymphocytes (76).

Seven minor lymphocyte-associated alloantigenic systems have been described using appropriately absorbed alloantisera raised by interstrain immunization with lymphoid cells in complementdependent cytotoxicity assays : e.g. $\mathrm{AgF}, \mathrm{AgG}, \mathrm{AgI}, \mathrm{AgJ}$, and $\mathrm{AgK}(14,15)$. Most interestingly expression of $\mathrm{AgF}$ was shown to be restricted to $T$ lymphocytes and was later assumed to be identical with the $\mathrm{T}$ cell-associated antigenic systems Pta (40), ART-2 (5l), and RT-Ly $2^{\mathrm{a}}(91)(70)$. Two alleles have been descri- 
bed for this locus. These antigens are expressed on a subset of peripheral $T$ lymphocytes but absent from thymocytes, B lymphocytes or bone marrow cells.

A second $\mathrm{T}$ lymphocyte alloantigenic system has been designated Ly-1 (17), RT-Lyl (9l) or ART-1 (70). Two alleles have been described for this system (called 1 and 2 for the RT-Lyll system and $a$ and $b$ for ART-1). Expression of these antigens is restricted to a subset of peripheral $\mathrm{T}$ cells and thymocytes.

Next to the alloantigenic systems defined by serological methods alloantigens may also be discriminated by killing of target cells by allosensitized cytotoxic $T$ cells $(52,53,75)$. Close association or identity of minor alloantigenic systems detected by different methodology may exist but awaits future analysis.

\subsection{Organ-specific alloantigenic systems}

The presence of major histocompatibility antigens on the surface of somatic cells of several organs has been demonstrated by the use of anti RTI alloantisera or monoclonal antibodies. As far as the kidney is concerned RTI.A-determined major transplantation antigens have been shown to be present with the highest antigen density on the surface of 'passenger' lymphoid cells and erythrocytes. Further, their presence on vascular endothelial, tubular and glomerular cells has been suggested (89). RT1. B-encoded antigens may have a similar distribution on kidney somatic cells $(12,36)$ although studies using monoclonal antibodies indicated restriction in the expression of these antigens to capillary endothelial cells (64).

Next to MHC-determined antigens minor alloantigenic systems as described in Sections 3.1 and 3.2 may be expressed on the surface of somatic cells of an organ, although no data on this subject have been reported thus far. Xenogeneic antisera can be raised against tissue or cell homogenates that are specific for one certain rat tissue but these xenoantisera are not likely to detect tissuespecific alloantigenic systems $(11,41,57)$. Only for the kidney an organ-specific alloantigenic system has been defined residing in the tubular basement membrane; this antigen was demonstrated to be present in animals of certain rat strains but to be absent from others $(37,50,84)$ (Table 11.1). Further, the capacity of kidney cells (54) (but also liver (68) and heart (44) cells) to stimulate 
TABLE II.1. Histocompatibility systems of the rat strains used in this study.

\begin{tabular}{|c|c|c|c|c|c|c|}
\hline \multirow{2}{*}{ Strain } & \multirow{2}{*}{$\begin{array}{c}\text { Designa- } \\
\text { lion }\end{array}$} & \multirow{2}{*}{ Source ${ }^{1}$ ) } & \multicolumn{4}{|c|}{$\begin{array}{l}\text { Histocompatibility } \\
\text { haplotype/allele }\end{array}$} \\
\hline & & & RT1 & RT2 & RT3 & $\begin{array}{l}\text { kidney } \\
\text { TBM Ag }\end{array}$ \\
\hline BD VII & BD VII & MPI & $\mathrm{e}$ & b & a & \\
\hline Brown Norway & $\mathrm{BN}$ & AZL/RL & $\mathrm{n}$ & $\left.a^{2}\right)$ & 0 & th \\
\hline Buffallo & BUF & MPI & $b$ & $a$ & 0 & + \\
\hline Fischer 344 & F344 & MRC & 1 & $\mathrm{a}$ & 0 & $t$ \\
\hline \multicolumn{7}{|l|}{ Hooded Oxford } \\
\hline \multirow[t]{2}{*}{$(=\mathrm{PVG} / \mathrm{c})$} & $\mathrm{HO}$ & MPI & $c$ & $b$ & a & \\
\hline & KHW & MPl & h & a & a & \\
\hline \multirow[t]{5}{*}{ Lewis } & LEW & AZL/RL & 1 & a & $a$ & $\ldots$ \\
\hline & LEW.IA & $\mathrm{MPI}$ & a & & & \\
\hline & LEW.ID & MPI & $d$ & & & \\
\hline & LEW.1F & MPI & $\mathrm{f}$ & & & \\
\hline & LEW.\|W & MPI & u. & & & \\
\hline Maudsley non-reactive & MNR & MPI & $\mathrm{m}$ & a & a & \\
\hline Sprague-Dawley & $\begin{array}{c}\text { Sprague- } \\
\text { Dawley }\end{array}$ & CPB & b & b & 0 & 1 \\
\hline Tokyo & TO & MPI & $\mathrm{t}$ & $a$ & a & \\
\hline Wistar & Wistar & $\mathrm{CPB}$ & u & b & $\mathrm{a}$ & + \\
\hline
\end{tabular}

1) Source: MPI, Max Planck Institut für Immunbiologie, F.R.G.; AZL. Academic Hospital Leiden; RL, Biomedical Center, University of Limm burg; MRC, Medical Research Council, Carshelton, England; CPB, Centraal Proefdierenbedrijf TNO, Zeist.

a) Data concerning RT 1, RT 2 and RT 3 were compiled from listings of inbred rat strains presented in references 23 and 48 ; data referring to the kidney TBM antigen from references 37,50 , and 84 .

3) As typed for the AZL/RL BN rats. 
MHC-compatible lymphocytes of rats from strains incompatible for non-MHC antigens suggested the presence of minor alloantigens on the surface of the stimulator cells. Obviously organ specificity was not established by these experiments.

An intriguing observation was made using a model of renal transplantation using AS donors ( $\mathrm{RT}^{1}$ ) and $\mathrm{AS} 2\left(\mathrm{RTI}^{\mathrm{I}}\right)$ recipients. In spite of the MHC incompatibility of donor and recipient more than $60 \%$ of renal grafts survived spontaneously for more than 100 days $(69)$. Using strains having the same RT1 disparity but with either different or no non-RTl incompatibilities both increased and decreased survival of renal grafts was observed; skin and heart allografts were always acutely rejected $(3,63)$. These findings suggested a kidney-specific effect of non-MHC genes on kidney allograft rejection possibly due to suppression or amplification of the HVG immune response. Whether antigenic differences or immune regulatory functions encoded outside the MHC effected such modifications of kidney allograft rejection has not been elucidated.

A survey of a number of alloantigenic systems relevant to our studies and their representation by the rat strains used in this study is presented in Table II.I.

\section{Summary}

Rejection or acceptation of allogeneic skin or vascularized organ grafts by unmodified recipients depends largely on the degree of compatibility of transplantation antigens of donor and recipient. Variation of the major histocompatibility antigens among the individuals of one species is due to the high degree of polymorphism found in the genetic loci coding for these antigens. Within one individual, expression of histocompatibility antigens varies among different cell types (differentiation antigens); the mechanism that accounts for this restriction of expression is unknown.

Functionally analogous regions present in the $\mathrm{MHC}$ of man. mouse, and rat are compared in this Chapter. The MHC of rat is described in detail and in addition minor histocompatibility systems relevant to our studies are reviewed. 


\section{References}

1 Alter, B. J., Schendel, D. J., BaCh, M. L., BaCh, F. H., Klein, J., and STMMPfliNG, J. H. : Cell-mediated lympholysis. Importance of serollogically defined $\mathrm{H}-2$ regions. J. Exp. Med. 137: 1303, 1973.

2 Begovitch, A. B., Winter, B. A., and Gasser, D. L. : Monoclonal antibody studies on the evolutionary relationships of la antigens. Transplant. Proc., in press.

3. Bishop, C. E., Paris, A. M. I., Festenstein, H., and Gunther, E.: The immunogenetic influence of non-MHS systems on rat renal allograft survival. Transplant. Proc. 1I: 1351, 1979.

4 Blankenhorn, E. P., Cecka, J. M., and Gömze, D. : Partial N-terminal amino acid sequence of rat transplantation antigens. Nature 274: $90,1978$.

5 Boyd, H., ZMIJEwski, C., and MCKFARN, T. J. : Monoclonal rat anti MHC alloantibodies detect polymorphisms in mice and humans which are linked to H-2 and HLA. Transplant. Proc., in press.

6. Butcher, G. W, and Howard, J. C.: A recombinant in the major histocompatibility complex of the rat. Nature $266: 362,1977$.

7 Carpenter, B. C., Terranova, C. M., Milford, E. L., lowry, R. P., Vitetta, E.; Paradrsz, J. M., Norman, O. J., and Morris, S." Evidence for a second Class II (Ia) antigenic system linked to RT1. Transplant. Proc. 11: 1582, 1979.

8 CoHEN, N., and Collins, N. H.: In: The Major Histocomparibility System in Man and Animals. D. Götze, (ed.), p. 313. Springer-Verlag. Berlin, 1977.

9 Counce, S., Smith, P., Barth, R., and Snell, G. D. : Strong and weak histocompatibility gene differences in mice and their role in the rejection of homografts of tumours and skin. Anm. Sing. 144: 198, 1956.

10. Cramer, D. V., Davis, B. K., Shonnard, J. W., and Gill, T. J. III : The graft versus host reactivity in Ag-B/MLR disparate strains of rats. Transplantation $23: 498,1977$.

11 Darnule, A. T., Parshley., M. S., Darnule, T. V., Likhite, V., Mande, I., and Turino, G. M. : Antiserum to surface antigens as a narker for cultured rat lung endothelial cells. Immunol. Comm. $7: 233,1978$.

12 DAviEs, H. fF. S., and BưrChER, G. W. : Kidney alloantigens determined by two regions of the rat major histocompatibility complex. Innmunogenetics $6: 171,1978$.

13 DENNERT, G., and HYMAN, R. : The importance of serologically detectable histocompatibility antigens in the induction and effector step of cellmediated lysis. Eur. J. Immunol. $7: 251,1977$. 
$\$ 4$ DE WrTt, C. W., and McCullough, M. : Ag-F : Serological and genetic identification of a new locus in the rat governing lymphocyte membrane antigens. Transplantation 19: 310, 1975.

15 De WrTt, C. W., and McCullovgh, M. : Lymphocyte membrane antigens in the rat: Two serologically determined loci at the MHC and three new minor histocompatibility loci. Transplont. Proc. 9:625, 1977.

16. EpsteIN, S. L., OzATO, K., and SACHS, D. H. : Blocking of allogeneic cell-mediated lympholysis by monoclonal antibodies to $\mathrm{H}-2$ antigens. J. Immwnol. 125: 129, 1980 .

17 Fabre, J. W., and MORris, P. J. : The definition of a lymphocyte-specific alloantigen system in the rat (Ly-1). Tissue Antigens 4:238, 1974.

18 Feighery, C., and Stastny, P. : HLA-D region-associated determinants serve as targets for human cell-mediated Jysis. J. Exp. Med. 149: $485,1979$.

19 Feighery, C., and Stastny, P. : Cell-mediated cytotoxicity against HLA$\mathrm{D}$ region products expressed in monocytes and B-lymphocytes. Immunogenetics 10: $31,1980$.

20 Francke, U., and Pellegrinio, M. E. : Assignment of the major histocompatibility complex to a region of the short arm of human chromosome 6. Proc. Nat. Acad. Sci. USA 74: 1147, 1977.

21 Frenzl, B., KREN, $V_{\text {, }}$, and STARK, O. : Attempts to determine blood groups in rats. Folia Biol. $6: 121,1960$.

22 Fu, S. M., Chlorazzi, N., Wang, C. Y., Montazeri, G., Kunkel, H. G., Ko, H. S., and Gortules, A. B. : Ia-bearing T lymphocytes in man. Their identification and role in the generation of allogeneic hellper activity. J. Exp. Med. $148: 1423,1978$.

23 Gasser, D. L. : Current status of rat ümmunogenetics. Adv. Immunol. 25 : 93, 1977.

24 Gasser, D. L. : Overwiew: The organization of immunogenetic loci in the Norway rat. Transplamt. Proc., in press.

25 Gasser, D. L., Winters, B. A., HaAs, J. B., MCKearn, T. J., and KENNETT, $\mathbb{R}$. H. : Monoclonal antïbody directed to a B-cell antigen present in rats, mice and humans. Proc. Nat. Acad. Sci. USA 76: $4636,1979$.

26 Gill, T. J. III, Cramer, D. V., and Kunz, H. W. : The major histocompatibility complex - comparison in the mouse, man and the rat. Am. J. Pathol. $90: 735,1978$.

27 Gorer, P. A. : The genetic and antigenic basis of tumour transplantation. J. Pathol. Bacteriol. 44: 691, 1937.

28 Gorer, P. A., Lyman, S., and Snell, G. D. : Studies on the genetic and 
antigenic basis of tumour transplantation; linkage between a histocompatibility gene and 'fused' in mice. Proc. Roy. Soc. (London) B $135: 499,1948$.

29 Götze, D. : An immunogenetic analysis of the MHC of the rat - AgB (RT1). I. Serologic data. Transplant. Proc. 11: 1337, 1979.

30 Günther, E. : Personal communication.

31 GüNTHER, E. : Close association between particular I region-determined cell surface antigens and Ir gene-controlled immune responsiveness to synthetic polypeptides in wild rats. Eur. J. Immunol. 9: 391, 1979.

32 Günther, E., and STARK, O. : In The Major Histocompatibility System in Man and Animals, D. Götze (ed.), p. 207, Springer-Verlag, Berlin, 1977.

33 Günther, E., and STARK, O.: At least two loci of the major histocompatibility complex can determine mixed lymphocyte stimulation in the rat. Tissue Antigens $11: 465,1978$.

34 Günther, E., and STARK, O. : The major histocompatibility system of the rat. Transplant. Proc. $11: 1550,1979$.

35 Günther, E., Stark, O., and KoCh, C. : Genetic definition of I regiondetermined antigens of the rat major histocompatibility complex. Eur. J. Immunol. 8 : 206, 1978.

36 HART, D. N. J., and FABrE, J. W. : Quantitative studies on the lissue distribution of Ia and SD antigens in the DA and Lewis rat strains. Transplantation $27: 110,1979$.

37 HART, D. N. J., and FABRE, J. W. : Kidney specific alloantigen system in the rat. Characterization and role in transplantation. J. Exp. Med. 15I: 651,1980 .

38 HART, D. N. J., and FABRE, J. W. : Substantial strain variations in the amount of RTI.A antigens expressed on erythrocytes : potential problems in the use of erythrocytes for typing studies. Trutsplanr. Proc., in press.

39 Heslop, B. F., and JoLLY, K. D. : Genetic control of hemagglutinin production against an $\mathrm{MHC}$ determined alloantigen in rats. Immunogenerics $8: 567,1979$.

40 HowARD, J. C , and SCOT, D. W. : The identification of sera dis linguishing marrow-derived and thymus-derived lymphocytes in the rat thoracic duct. Immunology $27: 903,1974$.

41 Jankovid, B. D.; Horvat, J.; Mitrovic, K., and Mostarica, M. : Rat brain-lymplocyte antigen: Characterization by rabbit antisera to rat brain tubulin and S-100 protein. Immunochem. 14: 75, 1977.

42 JOHNSEN, H. E. : Human B-blast specific target determinants in CMI. A methodological study. Tissue Antigens $15: 189,1980$. 
43 Kaldany, A., Carpenter, C. B., Shadur, C. A., George, K., Kundin, A. P., Suthanturan, M., and Strom, T. B. : Immunological properties of subcellular rat lymphocyte preparations. Primary allogeneic stimulation in vitro by fractions containing la (RT1-B) but not RTI-A antigens. J. Exp. Med. 151: 910, 1980.

44 Kashmwabara, H., Taha, M., SaKal, A., and Kountz, S. L. : Mixed heart cell--lymphocyte reactions and graft survival in Ag-B compatible rats. Transplantarion 23:53, 1977.

45 KLeIN, J. : Biology of the Mouse Histocompatibility-2 Complex, p. 163, Springer-Verlag, Berlin, 1975.

46 KLEIN, J. : In The Major Histocompatibitity System in Man and Animals. D. Götze (ed.), p. 339, Springer-Verlag, Berlin, 1977.

47 KohouTrova, M.; Günther, E., and Štark, O. : Genetic definition of a further gene region and identification of at least three different histocompatibility genes in the rat major histocompatibility system. Immunogenetics $11: 483,1980$.

48 KUNZ, H. W., and GILL, T. J. III : Red blood cell alloantigenic systems in the rat. J. Immunogenetics $5: 365,1978$.

49 Kvist, S., Eriksson, U., and Pererson, P. A. : Properties of purified papain-solubilized rat $\mathrm{AgB}$ antigens and reactivity of a xenoantiserum against the isolated antigens. Scand. $J$. Immunol. II : $63,1980$.

50 Lehman, D. H., LeE, S., Wilson, C. B., and Dixon, F. J. : Induction of antitubular basement membrane antibodies in rats by renal transplantation. Transplantation $17: 429,1974$.

51 LubarofF, D. M. : An alloantigenic marker on rat thymus and thymusderived cells. Transplant. Proc. 5: 115, 1973.

52 LYNCH, D. M., and DeWrTr, C. W. : Genetic identification of a locus linked to the rat MHC that codes for a membrane antigen detectable with cytotoxic T lymphocytes. J. Immunol. I2I: 2367, 1978.

53 Marshak, A., Doherty, P. C. and WILSON, D. B. : The control of specificity of cytotoxic $\mathrm{T}$ lymphocytes by the major histocompatibility complex $(\mathrm{Ag}-\mathrm{B})$ in rats and identification of a new alloantigen system showing no Ag-B restriction. J. Exp. Med. 146: 1773, 1977.

54 Mashimo, S., Sakal, A., Ochial, T., and Kountz, S. L. : The mixed kidney cell-lymphocyte reaction in rats. Tissue Antigens $7: 29 \|, 1976$.

55 Mason, D. W., and Gallico, G. G. : Tissue distribution and quantitation of Ia-like antigens in the rat. Eur. J. Immonol. $8: 741,1978$.

56 Miller, D. A., Kouri, R. E., Dev, V. G., Grewal, M. S. Hutton, J. J., and Miller, O. J. : Assignment of four linkage groups to chromosomes in Mus musculus and a cytogenetic method for locating their centromeric ends. Proc. Nat. Acad. Sci. USA 68: 2699, 1971. 
57 Morkis, R. J., and Whlimis, A. F. : Antigens on mouse and rat lymphocytes recognized by rabbit antiserum against rat brain : the quantitative analysis of a xemogeneic antiserum. Eur. J. Immonol. $5: 274,1975$.

58 Murphy, D. B., Herzenibrg, L. A., Okumura, K., Herzianberg, L. A., and MCDEvitr, H. O.: A new I sub-region (I-J) marked by a locus (Ia-4) controlling surface determinants on suppressor T cells. J. Exp. Med. 144: 699, \976.

59 Nabiol, M., Young, H., Rynbeek, A., Boccardo, R, David, C. S. Meo, T.; Miggiano, $\mathrm{V}$., and Schreffler, D. C. : I-region-associated deteminants : expression on mitogen-stimulated lymphocyles and deteciion by cytotoxic T cells. Eur. J. Immunol. 5 : 594, 1975.

60 Natolr, T, Ohhashi, T., Kotani, T., Katagiki, M., and Aizawa, M.: The molecullar identification of two serologically defined gene products of the rat major histocompatibility complex. $J$. Immunol. $122: 1911$, 1979.

61 Palm, J. : Current status of blood groups in rats. Am. N.Y. Acad. Sci. 97 : $57,1962$.

62 PALM, J., and BLACK, G. : Interrelationships of inbred rat strains with respect to $\mathrm{Ag}-\mathrm{B}$ and non-Ag-B antigens. Transplantation $/ 1: 184,1971$.

63 Paris, A. M. I., Bishop, C., Festenstein, H., and Günther, E. : Nonmajor histocompatibility system infuences in rat renal allograft survival. Transplantation 25:252, 1978.

64 Paul, L. C., Milford, E. L., Paradysz, J. M., and Carpenter, C. P. : Alloantigens on the endothelium of rat kidneys. Transplant. Proc., in press.

65 Robinson, R. : Linkage groups. Rat News Letter 4: 35, 1978.

66 RoOD, J. J. VAN, and LEEUWEN, A. WAN: In Textbook of Immunopathology, P. A. Miescher and H.-J. Miiller-Eberhard (cds), p. 663, Grune and Stratton, New York, 1976.

67 Sachs, D. H., Humprerey, G. W., and Lunney, J. K. : Sharing of la antigens between species. 1. Detection of la specificities shared by rats and mice. J. Exp. Med. $146: 381,1977$.

68 Sakal, A., Tanaka, S., and Kountz, S. L. : Liver and immune responses. IV. Characteristics of the liver cell-lymphocyte interaction. Transplanfation 25: 110, 1978.

69 Salaman, 3. R., Elves, M. W., and Festenstein, H. : Factors contributing to survival of rats transplanted with kidneys mismatched at major locus. Transplant. Proc. 3: 577, 1971.

70 SECOND international workshop on alloantigenic systems in the rat: Combined report on reference typing of anti-T-lymphocyte alloantisera. Transplant. Proc. II: 1648, 1979. 
71 SHAw, S., JOHNSON, A. M., and SHEARER, G. M. : Evidence for a new segregant series of $\mathbf{B}$ cell antigens that are encoded in the HLA-D region and that stimulate secondary allogeneic proliferative and cytoLoxic responses. J. Exp. Med. 152: $565,1980$.

72 Shinghara, N., Cullen, S. E., and SAChs, D. H. : Ag-B-linked analogue of lla antigens in the rat. J. Inmunol. 118: 2083, 1977.

73 SHINOHARA, N., LUNNE, J. K., and SACHS D. H. : Sharing of Ia antigens between species. II. Molecular localization of shared Ia determinants implies the existance of more than one I sublocus of the rat MHC. J. Jmmunol. $121: 637,1978$.

74 Shonnard, J. W., Davis, B. K., Cramer, D. V., Radka, S. F., and GiLt, T. J. III : The association of immune responsiveness, mixed lymphocyte responses and $\mathrm{I}$ a antigens in natural populations of Norway rats. J. Immonol. 123:778, 1979.

75 Sieck, T., Marshak-Rothstein, A., and WILSON, D. B. : Studies of the MHC-linked "CT" alloantigenic systems in rats. I. Neither and SD nor an LD gene product. Immunogenetics 9: 1.65, 1979.

76 Sulvers, W. K., Murphy, G., and Poole, T. W. : Studies on the H-Y antigens in rats. Immunogenerics 4: 85, 1977.

77 Smilrk, D. E., Boyd, H. C., Wilson, D. B., Smiewski, C. M., Fittch, F. W., and MCKEARN, T. J. : Monoclonal rat anti-major histocompatibility complex antibodies display specificity for rat, mouse and human target cells. J. Exp. Med. 15I: 1139, 1980.

78 Snell., G. D. : Methods for the study of histocompatibility genes. J. Genetics 49: 87, 1948.

79 Storer, R., Black, G., Rigiero, C. Manson, L., and Götze, D. : The major histocompatibility complex of the rat, RTI. II. Biochemical evidence for a complex genetic organization. Immunogenetics $7: 507$, 1978.

80 SPORER, R., MANSON, L. A., and Görze, D. : A biochemical analysis of the membrane-associated gene products of major histocompatibility complex of the rat. $J$. Immunol. 122: 2162, 1979.

81 Śtark, O., Günther, E., Kohoutrova, M., and Voscik, L. : Genetic recombination in the major histocompatibility complex $(\mathbf{H}-1, \mathbf{A g - B})$ of the rat. Immunogenetics $5: 183,1977$.

82 Śtark, O., GUnTher, E., Kohoutova, M., and Volcik, L. : Three recombinants in the major histocompatibility complex of the rat. Transplant. Proc, $11: 1340,1979$.

83 STOCK, W., and GÜNTHER, E. : Serologic analysis of two new alloantigenic systems of the rat major histocompatibility complex. Transplant. Proc. II: $1579,1979$. 
84 Sugisaki, T., Klassen, J, Milgrom, F., Andres, G. A., and MoClusker, R. T. : Immunopathologic study of an autoimmume tubular and interstitial renal disease in Brown Norway rats. Lab. Invest. $28: 658,1973$.

85 Teh, H.-S., Letarte, M., Philips, R. A., and Miller, R. G. : Characterization of the target cell antigen in 1 region-nediated lympholysis. Cell. Imm. 37: 397, 1978.

86 Termitelen, A., Boettcher, B., Bradley, B., d'Amaro, J. D., LeeuWEN, A., VAN and ROOD, J. J. VAN : DR typing in Australian aborigines. An indication for a second locus in the HLA-D region defined by serology. Tissue Antigens $16: 140,1980$.

87 THIRD international workshop on alloantigenic systems in the rat. Transplant Proc., in press.

88 Tosi, R., Tanigahi, N., Centis, D., Ferrara, B., and Pressman, D.: Immunological dissection of human la molecules. $J$. Exp. Med. 148: $159,1978$.

89 Willebrand, E. von, Parthenais, E., and Häyry, $P$. : Expression of the major AgB histocompatibility conplex antigens on different structural components of rat kidney and heart. Cell. Immunol. $52: 313,1980$.

90 WOLF, S. J., and EL.KINS, W. L. : Cell-mediated cytotoxicity engendered by IB-G-region determinants of the $\mathrm{H}-2$ complex. Absence of $\mathrm{H}-2 \mathrm{~K}$ and $D$ restriction. Immunogenetics $8: 171,1979$.

91 WonIGeiT, K. : Characterization of the RT-Ly-1 and RT-Ly-2 alloantigenic systems by congenic rat strains, Transplant. Proc. 1/: 1631, 1979. 
CHAPTER III

\section{MATERIALS AND METHODS}

\section{Rats}

Male rats from 15 different inbred rat strains were used. A survey of these strains including a number of relevant immunogenetical characteristics as well as their source of origin has been presented in Chapter II (Table II.1).

$B N$ and LEW rats were bred under conventional circumstances according to a full sib-mating protocol at the Dept. of Experimental Animal Services of the University of Limburg, Biomedical Center. Rats were supplied with normal tap water and rat chow (Hope Farms, Woerden, the Netherlands) ad libitum.

Compatibility for transplantation antigens within one rat strain was checked repeatedly by exchanging skin grafts between animals of that strain of the same sex and age. To ensure histocompatibility of the Maastricht rat strains with the same strains used elsewhere skin grafts were also exchanged between LEW and BN rats bred at Maastricht and at the Max Planck Institute for Immunobiology at Freiburg, F.R.G. Skin grafts were accepted for over two months without macroscopical signs of rejection.

\section{Renal transplantation}

Kidneys were transplanted according to the method of LiE (22) with the modifications of LAMEIJER et al. (21) for the urether-bladder anastomosis. Both recipient kidneys were removed during the operation when graft rejection time was to be determined.

Just prior to and every second day after grafting about $0.75 \mathrm{ml}$ of blood was taken from the graft recipient by retro-orbital puncture up to 14 days after transplantation. Thereafter, blood samples were collected weekly.

Serum urea concentrations were measured using urease according to protocol nr. 2412 of the Dutch Rijksinstituut voor de Volksgezondheid. Transplantations were considered technically successful when the serum urea concentration did not exceed $200 \mathrm{mg} / 100 \mathrm{ml}$ 
on the second day postoperatively and if severe hydronephrosis was absent at autopsy. Renal graft rejection was equated to a rise in serum urea concentration over $400 \mathrm{mg} / 100 \mathrm{ml}$. If necessary rejection time was determined by interpolating between two serum urea concentrations assuming a linear increase between both points measured. Recipients were sacrificed on the 50th day after transplantation if rejection had not occurred.

\section{Thoracic duct cannulation}

Cannulation of the thoracic duct was performed according to the technique of BolLman et al. (4). Rats were continuously infused via the jugular vein with DPBS at a rate of $2 \mathrm{ml} / \mathrm{hour}$. Cannulated. fluid was collected in DBSS in sterile bottles at $4{ }^{\circ} \mathrm{C}$.

\section{Media}

DBSS. The balanced salt solution used was a modification of Dubbecco's phosphate buffered saline. It contained the following components (concentration in $\mathrm{mg} / \mathrm{l}$ ) : $\mathrm{NaCl}(8140), \mathrm{KCl}(220)$, $\mathrm{MgSO}_{4} .7 \mathrm{H}_{2} \mathrm{O}(110), \mathrm{Na}_{2} \mathrm{HPO}_{4} \cdot 2 \mathrm{H}_{2} \mathrm{O}(1960), \mathrm{CaCl}_{2}$ (110), D-Glucose (1100), and phenolred (10). If necessary the $\mathrm{pH}$ of the final solution was adjusted to 7.4 and osmolarity to $283 \mathrm{mOsm}$.

Working medium. HEPES-buffered RPMI-1640 (Flow Laboratories, Irvine, Scotland) was used as working medium. It was supplemented with $50 \mathrm{U}$ penicillin and $50 \mu \mathrm{g}$ streptomycin $/ 100 \mathrm{ml}$. L-glutamine was added to reach a final concentration of $40 \mathrm{mM}$ and IFCS to $5 \%(\mathrm{v} / \mathrm{v})$.

Culture medium. $\mathrm{NaHCO}_{3}$-buffered RPMI-1640 (Flow Laboratories, Irvine, Scotland) was used for culturing of rat lymphoid cells. Antibiotics and L-glutamine were added as indicated for working medium. Depending on the experiment the medium was supplemented either with $10 \%(\mathrm{v} / \mathrm{v}) \| \mathrm{FCS}$ of with $15 \%(\mathrm{v} / \mathrm{v})$ heat-inactivated normal $\mathrm{BN}$ rat serum.

BB. $3 \mathrm{~m} M$ Barbital-buffered saline $\mathrm{pH} 7.4$ containing $0.5 \mathrm{~m} M \mathrm{Mg}^{2++}$ and $0.15 \mathrm{mM} \mathrm{Ca}{ }^{2+}$ was gassed with oxygen at $0{ }^{\circ} \mathrm{C}$ just prior to use and supplied with $10 \%(\mathrm{v} / \mathrm{v})$ IFCS. 


\section{X-irradiation}

X-rays were generated by a Philips-Müller MG 300 apparatus and additionally filtered through $1.0 \mathrm{~mm} \mathrm{Cu}$. The thickness of this filter was adapted to correct for field inhomogeneity. Subjects to be irradiated were placed on a layer of $11 \mathrm{~cm}$ hardboard to obtain maximal backscatter. X-ray dose was measured during irradiation using a $0.6 \mathrm{cc}$ ionization chamber connected to a digital dose/ doserate meter (Ionex 2500-3, Nuclear Enterprises, Beenham, England).

Cell suspensions were irradiated on ice at a source to target distance of $21 \mathrm{~cm}$. X-rays were generated at $250 \mathrm{kV}, 10 \mathrm{~mA}$ and administered to the suspensions at a dose-rate of $150 \mathrm{rad} / \mathrm{min}$.

Up to three rats were placed in a well-aerated round perspex box and irradiated at a source to subject distance of $42.5 \mathrm{~cm}$. $\mathrm{X}$-rays were generated at $250 \mathrm{kV}, 10 \mathrm{~mA}$ and administered to the rats at a dose-rate of $55 \mathrm{rad} / \mathrm{min}$. Lethally irradiated rats were reconstituted the same day with $5 \times 10^{7}$ syngeneic bone marrow cells i.v.

\section{Isotope labelling}

\section{$6.1 \mathrm{Cells}$}

${ }^{51} \mathrm{Cr}$. Labelling of cells with ${ }^{51} \mathrm{Cr}$ was achieved by addition of $\mathrm{Na}_{2}{ }^{51} \mathrm{CrO}_{4}$ (Radiochemical Centre, Amersham, England; specific activity $200-350 \mathrm{mCi} / \mathrm{mg} \mathrm{Cr}$ ) to cells resuspended in a small volume.

Lymph node cells were labeled at a concentration of $5 \times 10^{7} / \mathrm{ml}$ $\mathrm{BB}$ in a $1.0 \mathrm{ml}$ volume by addition of $50 \mu \mathrm{Ci}{ }^{51} \mathrm{Cr}$.

Thymocytes were labeled at a concentration of about $3 \times 10^{2} / \mathrm{ml}$ working medium in a $0.5 \mathrm{ml}$ volume by addition of $300{ }_{22} \mathrm{Ci}{ }^{51} \mathrm{Cr}$.

Lectin-stimulated lymphoblasts were labeled at a concentration of $5 \times 10^{6} / \mathrm{ml}$ working medium in a $0.5 \mathrm{ml}$ volume by addition. of $60 \mu \mathrm{Ci}{ }^{51} \mathrm{Cr}$. For any suspension labelling was allowed to proceed for $45 \mathrm{~min}$ at $37^{\circ} \mathrm{C}$. The labeled cells were washed twice in $40 \mathrm{ml}$ of labelling medium to remove free ${ }^{5 x} \mathrm{Cr}$.

${ }^{11} \mathrm{~m}$. Thoracic duct leukocytes were labeled with "11In-oxine according to the procedure of THAKuR et al. (28). 111n (BykMallinckrodt, Petten, the Netherlands; activity $1 \mathrm{mCi} / \mathrm{ml}$ ) was chelated with 8-hydroxyquinoline to form 111 In-oxine according 
to the instructions of the manufacturer. Leukocytes were labeled at a concentration of $5 \times 10^{7} / \mathrm{ml}$ PBS in a $1.0 \mathrm{ml}$ volume by addition of $60 \mu \mathrm{Ci}{ }^{11}$ In-oxine. Labelling was continued for $20 \mathrm{~min}$ at room temperature. Labeled cells were washed once in $40 \mathrm{ml}$ PBS and 4 times in DBSS.

\subsection{Immunoglobulins}

Purified BN IgG (1.5 mg in $1.0 \mathrm{ml}$ PBS) was iodinated with either $1.5 \mathrm{mCi}{ }^{131} \mathrm{I}$ or $5 \mathrm{mCi}{ }^{125}$ I (supplied as sodium iodide, Radiochemical Centre, Amersham, England; specific activities : ${ }^{131} \mathrm{l}, 7-26 \mathrm{mCi} / \mu \mathrm{g} \mathrm{I}$; $\left.{ }_{125} \mathrm{l}, 11-17 \mathrm{mCl} / \mu \mathrm{g} \mathrm{l}\right)$ by addition of $20 \mu \mathrm{g}$ chloramine- $\mathrm{T} / \mathrm{ml}(5)$. Iodination proceeded for $10 \mathrm{~min}$ at $0^{\circ} \mathrm{C}$ and was terminated by addition of sodium-disulfite. IgG was separated from free iodine by passage over a disposable $1 \times 25 \mathrm{~cm}$ G-75 Sephadex column. Fractions eluted containing over $90 \%$ trichloracetic acid-precipitable material were pooled and deaggregated by ultracentrifugation for $120 \mathrm{~min}, 40.000 \times \mathrm{g}$ at $4^{\circ} \mathrm{C}$ and by in vivo passage through a BN rat for 6 hours. Specific activity/ng IgG was determined from the supernatant after ultracentrifugation. From this standard, the amount of labeled IgG present in the serum of the BN rat used for in vivo deaggregation was calculated. For paired label binding studies, volumes of serum containing equal amounts of 131 [-labeled IgG and ${ }^{125}$ I-labeled IgG were mixed.

\section{Cell suspensions}

\subsection{Erythrocytes}

Rat blood was collected from the abdominal aorta and defibrinated by shaking for $10 \mathrm{~min}$ with glass beads. Blood was centrifuged for 10 min at $200 \times \mathrm{g}$, the buffy coat was removed, and the sediments were pooled and passed in PBS pH 7.3 over a cotton wool column (Dutch Red Cross Blood Transfusion Service; Amsterdam) (9). Next, the packed erythrocyte suspension was incubated with rat erythrocyte-absorbed rabbit anti rat thymocyte serum. The suspension was washed with PBS and incubated for an additional $15 \mathrm{~min}$ with fresh autologous serum at $37^{\circ} \mathrm{C}$. Cells were washed again and allowed to sediment in the presence of $1 \%$ gelatin at $37^{\circ} \mathrm{C}$ (Bacto Gelatin, Difco, Detroit). The sediment was washed 
twice in PBS, cells were counted on a Coulter Counter and the suspension was adjusted to $1 \times 10^{10}$ erythrocytes $/ \mathrm{ml}$.

Efficiency of the purification procedure was determined by adding syngeneic, radioactivity-labeled thoracic duct leukocytes to a partially purified erythrocyte suspension and measuring residual radioactivity in the final purified erythrocyte suspension. Leukocytes were freed from erythrocytes and labeled with ${ }^{11}$ Indiumoxine. "IIIndium-labeled leukocytes $(0.64 \mathrm{cpm} /$ leukocyte $)$ were added. to the erythrocyte suspension just prior to passage over a cotton wool column. On the basis of the residual radioactivity measured in $10 \mathrm{ml}$ of the final purified erythrocyte suspension 1543 leukocytes were callculated to be present per $1 \times 10^{10}$ erythrocytes. To decide whether this radioactivity was due to the presence of 11 Indiumlabeled leukocytes the erythrocytes were lysed by incubation for $10 \mathrm{~min}$ in a total volume of $400 \mathrm{ml}$ cold isotonic $0.15 \mathrm{M} \mathrm{NH} \mathrm{NH}_{4} \mathrm{Cl}$ solution. Forty $\mathrm{ml}$ aliquots of the lysate were spun for $10 \mathrm{~min}$ over $5 \mathrm{ml}$ of IFCS at $1000 \times \mathrm{g}$. Pellets were collected in $1.0 \mathrm{ml}$ and residual radioactivity was determined. Since radioactivity was reduced by $97 \%$ after lysis of the erythrocytes, most of the radioactivity in the purified erythrocyte suspension was thought to be due to uptake of "111 Indium by erythrocytes. As calculated from the residual radioactivity after erythrocyte lysis, the purified erythrocyte suspension contained one leukocyte per $2.7 \times 10^{8}$ erythrocytes (Table III.1).

In order to monitor leukocyte contamination of erythrocyte suspensions 200 samples were drawn from the final suspension and lysed by incubation for 10 min with $6 \mathrm{ml}$ cold $0.15 \mathrm{M} \mathrm{NH}_{4} \mathrm{Cl}$ solution. Leukocytes were recovered by centrifugation of the lysate for $20 \mathrm{~min}$ at $50 \times \mathrm{g}$ over $1 \mathrm{ml}$ of IFCS. The pellet was left in about $50 \mu \mathrm{l}$, resuspended and the whole volume transferred to a cytocentrifuge. The cytocentrifuge preparation was stained with May-Grunwald-Giemsa and the whole field of sedimentation screened under a microscope for the presence of residual leukocytes. From an experiment in which known amounts of leukocytes were added to $200 \mu \mathrm{l}$ samples of a purified erythrocyte suspension, efficiency of leukocyte recovery in cytocentrifuge preparations was determined to be $22 \%$ (Table III.2). Cytocentrifuge preparations derived from purified erythrocyte suspensions never contained more than 3 intact leukocytes per sedimentation field, indicating that less than one leukocyte was present per $1 \times 10^{8}$ erythrocytes. 


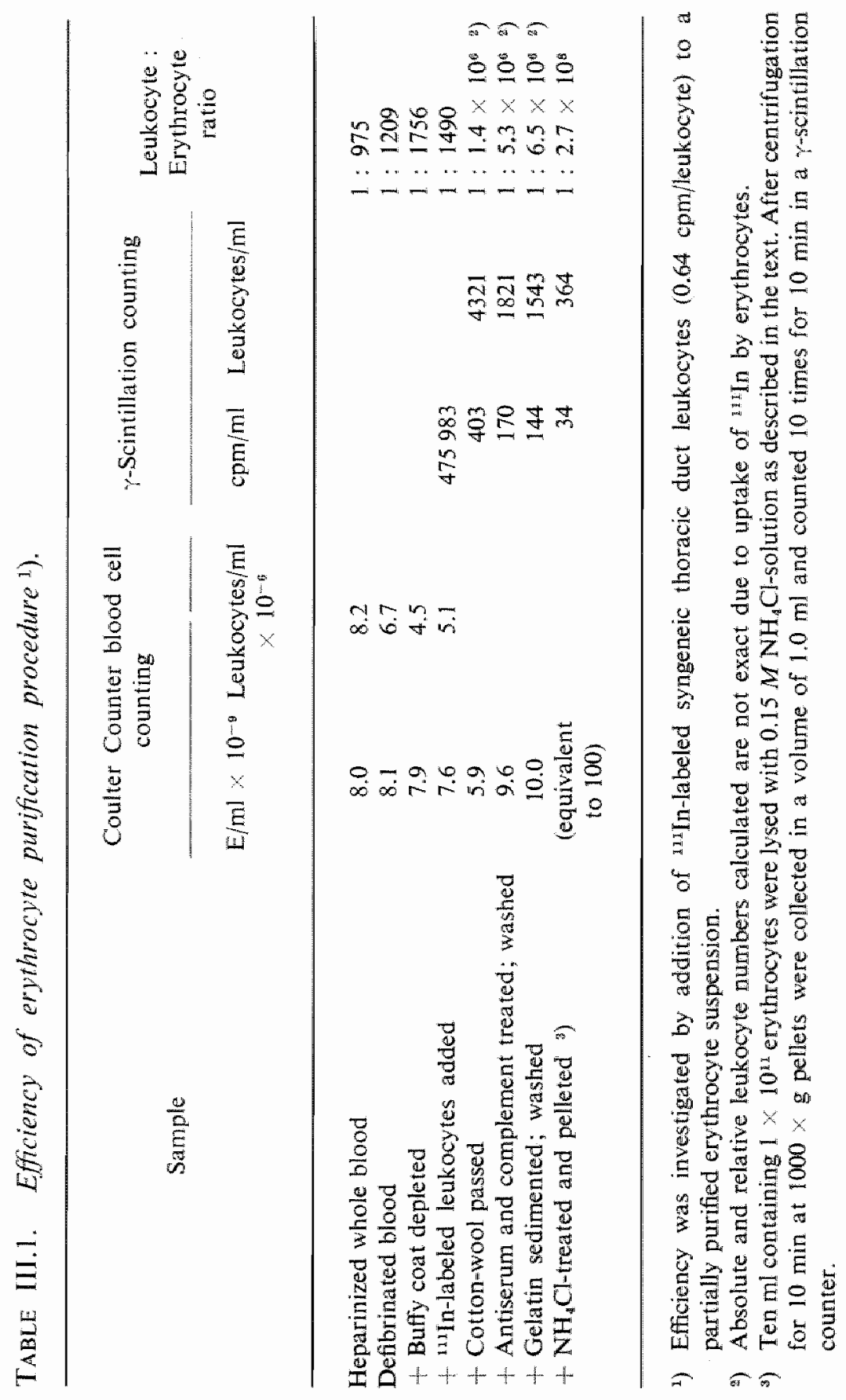


TABLE: III.2. Recovery of leukocytes in cytocentrifuge preparations from lysed samples of a purified erythrocyte suspension ${ }^{1}$ ).

\begin{tabular}{cccc}
\hline & \multicolumn{2}{c}{ Recovery (mean of duplo) } & \\
\cline { 2 - 3 } Leukocytes added & $\begin{array}{c}\text { Absolute } \\
\text { numbers }\end{array}$ & $\begin{array}{c}\text { Corrected for } \\
\text { background }\end{array}$ & \\
& & & \\
\hline & 0.5 & 0 & - \\
none & 3.5 & 3.0 & 30 \\
10 & 8.5 & 8.0 & 16 \\
50 & 20.5 & 20.0 & 20 \\
\hline 100 & & & \\
\hline
\end{tabular}

1) Leukocytes were added to $200 \mu 1$ samples of a purified erythrocyte suspension $\left(10^{10}\right.$ erythrocytes $/ \mathrm{ml}$ ) Samples were lysed by incubation for $10^{\prime}$ in $6 \mathrm{ml} 0.15 \mathrm{M} \mathrm{NH}_{4} \mathrm{Cl}$-solution and the leukocytes were recovered by centrifugation through a cushion of IFCS. Cytocentrifuge preparations were made of the pellets and next screened microscopically.

\subsection{Lymphoid cells}

Crude lymphoid cell suspensions were obtained from spleen, thymus or mesenteric and submandibular lymph nodes. The donor rat was exsanguinated under ether anaesthesia, killed, and the lymphoid organs or lymph nodes were removed. When thymocyte suspensions were to be prepared care was taken not to include the parathymic lymph nodes. Lymph nodes were freed of fat and capsule to avoid formation of aggregates in the final lymph node cell suspension. Next, the lymphoid organ or lymph nodes were cut with scissors on a Monodur PA $100 \mathrm{n}$ nylon gauze sieve (Stokvis, Haarlem, the Netherlands) under dropwise addition of cold DBSS or working medium. The resulting lymphoid cell suspension was washed once $\left(10^{\prime}, 250 \times \mathrm{g}\right.$ at $\left.4^{\circ} \mathrm{C}\right)$, resuspended in DBSS or working medium and counted at a 1:5 to I: 100 dilution in a Tris-buffered $2 \%(\mathrm{w} / \mathrm{v})$ solution of trypan blue. The percentage of trypan blue-positive cells was about 2 for thymocytes, 35 for splenocytes and 40 for lymph node cells. When desired contaminating dead cells and erythrocytes were removed by cen- 
trifugation in a two-phase gradient of Percoll prepared according to Kurnick (20). Briefly, Percoll (Pharmacia, Uppsala, Sweden) was made isotonic to rat cells by adding one part $10 \times$ concentrated PBS to 9 parts of Percoll; $\mathrm{pH}$ was adjusted to 7.4. Designating this solution as $100 \%$ Percoll, dilutions of $80 \%$ Percoll and $30 \%$ Percoll were prepared with PBS pH 7.4. The lymphoid cell suspension was transferred to $10 \mathrm{ml}$ cellulose-nitrate tubes, centrifuged for $10^{\prime}, 250 \times \mathrm{g}$ at $4^{\circ} \mathrm{C}$ and resuspended in $5 \mathrm{ml}$ Percoll $80 \%$. Five ml Percoll $30 \%$ was layered on top and the tubes were centrifuged for $10^{\prime}, 600 \times \mathrm{g}$ at room temperature. At the $30 \%-80 \%$ Percoll interphase $90 \%$ of the viable lymphocytes were recovered; dead cells concentrated on top of the fluid and erythrocytes sedimented at the bottom of the tube.

\subsubsection{T lymphocyte purification}

$\mathrm{T}$ lymphocytes were purified according to JuLIus et al. (17). Barrels of $10 \mathrm{ml}$ syringes were packed with $0.6 \mathrm{~g}$ dry weight of washed nylon wool (Leuko-pak, Fenwal! Laboratories, Deerfield, Mllinois) and preincubated with medium (DBSS or working medium) at $37^{\circ} \mathrm{C}$ prior to use. One $\mathrm{ml}$ of leukocyte suspension containing up to $1.5 \times 10^{8}$ cells was passed into the nylon wool with $1.5 \mathrm{ml}$ of medium warmed to $37^{\circ} \mathrm{C}$. After $45 \mathrm{~min}$ of incubation at $37^{\circ} \mathrm{C}$ nylon wool non-adherent cells were eluted with $10-15 \mathrm{ml}$ of warm medium. When desired, nylon wool adherent cells were recovered by three cycles of squeezing and rehydration of the nylon wool with medium using the piston of the syringe to exert pressure (15).

Purity of nylon wool eluted cells was determined both by differentiation of May-Grünwald-Giemsa-stained cytocentrifuge preparations and by enumeration of surface-Ig positive cells by immunofluorescence. For the latter technique, cells were incubated at $0^{\circ} \mathrm{C}$ with rabbit $\mathrm{F}(\mathrm{ab})_{2}$ anti rat $\mathrm{F}(\mathrm{ab})$, washed twice at $4^{\circ} \mathrm{C}$ and incubated next with goat $\operatorname{lgG}$ anti rabbit $\lg G$ conjugated at a $6.6: 1 \mathrm{FITC} /$ protein ratio with FITC. Cells were washed again and enclosed in Tris-glycerine $\mathrm{pH} \mathrm{8.0.} \mathrm{According} \mathrm{to} \mathrm{this} \mathrm{protocol} \mathrm{crude}$ spleen cell suspensions contained $30 \%$ surface-Ig positive cells; after passage through a nylon wool column this number was reduced to $6 \%$. Light microscopy of cytocentrifuge smears revealed the nylon wool non-adherent spleen cells to be void of monocytes. 
and macrophages but to be contaminated with $7 \%$ polymorphonuclear leukocytes.

\subsection{Elimination of erythrocytes}

As an alternative to the density centrifugation procedure described in Section 7.2 erythrocytes were removed from lymphoid cell suspensions by lysis with a $0.15 \mathrm{M} \mathrm{NH} \mathrm{NH}_{4} \mathrm{Cl}$-solution prepared according to Roos et al. (26). Pelleted cells were resuspended in cold ( $\left.4^{\circ} \mathrm{C}\right) \mathrm{NH}_{4} \mathrm{Cl}$-solution and left as such for $10 \mathrm{~min}$. Meanwhile a cushion of IFCS was slowly introduced at the bottom of the tube; undamaged cells were separated from lysed erythrocytes by centrifugation $\left(10-20 \mathrm{~min}, 50 \times \mathrm{g}\right.$ at $\left.4^{\circ} \mathrm{C}\right)$.

\section{Lymphoblasts}

\subsection{Lectim-stimulation of lymphocytes}

Con-A. Lymph node cells were harvested in working medium and freed from erythrocytes and dead cells by passage over a discontinuous Percoll gradient. Cells harvested from the gradient interphase were washed twice and resuspended to a concentration of $2 \times 10^{6} / \mathrm{ml}$ in culture medium containing $5 \times 10^{-5} \mathrm{M} 2$-mercaptoethanol (2-ME), $15 \%(\mathrm{v} / \mathrm{v})$ heat-inactivated $\mathrm{BN}$ rat serum and 25 ug Con-A (Pharmacia, Uppsala, Sweden)/ml (19). Two ml volumes of this suspension were seeded into the $16 \mathrm{~mm}$ diameter wells of tissue cluster plates (Costar \# 3524, Cambridge, Mass.) and incubated for 48 hours in a humidified atmosphere of $5 \% \mathrm{CO}$ in air at $37^{\circ} \mathrm{C}$.

PHA. Lymph node cells or nylon wool passed spleen cells were used to obtain PHA-stimulated lymphoblasts. Procedures were identical to those described for the generation of Con-A-stimulated lymphoblasts but Con-A was replaced by $12.5 \mu \mathrm{l}$ of PHA solution (Wellcome Reagents, Beckenham, England)/ml culture medium (19).

LPS. Cell suspensions were obtained as indicated for PHAstimulated lymphoblasts. Nylon wool adherent spleen cells were used for LPS-induced blastogenesis. The culture technique was the same as described for Con-A-stimulated lymphoblasts but Con-A was replaced by $200 \mu \mathrm{g}$ LPS (from E.coli 0111 B4; Difco, Detroit)/ ml culture medium (19). 


\subsection{Purification of lymphoblasts}

After two days of cuituring lymphoid cells in the presence of lectin, $0.5 \mathrm{ml}$ of a sterile carbonyl iron suspension (Technicon, Tarrytown, New Yersey) was added to each well of the tissue cluster plate. Incubation was continued for $45 \mathrm{~min}$ to allow engulfment of carbonyl iron particles by phagocytes (13). Cells were harvested from the wells by vigorous resuspending with a pasteur pipette, collected in $50 \mathrm{ml}$ centrifuge tubes (Falcon \#2070 F, Becton-Dickinson, Naarden, the Netherlands) and pelled by centrifugation for $10 \mathrm{~min}, 250 \times \mathrm{g}$ at $4^{\circ} \mathrm{C}$. Pellets were resuspended in a small volume of working medium and cell aggregates were dislodged by passing the cell suspension several times through the $0.65 \mathrm{~mm}$ lumen of a $28 \mathrm{~mm}$ long injection needle. Phagocytes containing carbonyl iron and free carbonyl iron were next concentrated using a strong permanent magnet and the iron-free cell suspension was aspirated. When desired, cells contained in this suspension were prepared for storage in liquid nitrogen according to the method of WeINER ( $3 I$ ). For this purpose cells were counted, washed, pelleted by centrifugation for $10 \mathrm{~min}, 250 \times \mathrm{g}$ at $4^{\circ} \mathrm{C}$ and resuspended in an aliquot of working medium containing $10 \%(\mathrm{v} / \mathrm{v})$ IFCS to reach a concentration of $2 \times 10^{7}$ cell $\mathrm{s} / \mathrm{ml}$. This suspension was slowly mixed with an equal volume of working medium supplemented with $10 \%(\mathrm{v} / \mathrm{v})$ IFCS and $20 \%(\mathrm{v} / \mathrm{v})$ dimethylsulphoxide (DMSO). One $\mathrm{ml}$ portions of the resulting suspension were distributed to $2.5 \mathrm{ml}$ pollycarbonate freezing ampoules and frozen with liquid nitrogen in freezing equipment (Cryoson, Midden-Beemster, the Netherlands) directed by an empirically developed program. Ampoules were stored in liquid nitrogen.

Non-stimulated lymphocytes and lymphoblasts contained in freshly harvested or frozen-stored and thawed suspensions were separated on two-phase Percoll gradients as follows. Cells were pelleted in cellulose-nitrate centrifuge tubes and subsequently resuspended in $5 \mathrm{ml}$ of a $60 \%$ Percoll dilution prepared as indicated in Section 7.2. Five $\mathrm{ml}$ of a $30 \%$ Percoll dilution was layered on top of the cell suspension and the tubes were centrifuged for $10 \mathrm{~min}, 600 \times \mathrm{g}$ at room temperature. Cells recovered from the interphase were usually $80-90 \%$ pure $l y m p h o b l a s t s$ but were 
sometimes contaminated with dead cells (especially with LPSstimulated lymphoblasts). In order to remove dead cells, cells were washed in working medium, resuspended in working medium and up to $5 \times 10^{7}$ cells in a $6 \mathrm{ml}$ volume were spun in $15 \mathrm{ml}$ plastic centrifuge tubes (Falcon \# 2095, Becton-Dickinson, Naarden, the Netherlands) over $3 \mathrm{ml}$ Lymphoprep (Nyegaard, Oslo, Norway; density $1.077 \mathrm{~g} / \mathrm{ml}$ at $20^{\circ} \mathrm{C}$ ). Centrifugation was carried out at room temperature for $12 \mathrm{~min}$ at $200 \times \mathrm{g}$. All fluid was aspirated and the cells washed twice in $40 \mathrm{ml}$ volumes of working medium. Only lymphoblast suspensions containing less than $15 \%$ dead cells were used as target cell suspensions in cytotoxicity assays.

\section{Mixed lymphocyte culture ( $M L C)$}

Unilateral MLC was performed as described by KRUISBEEK et al. (18). Briefly, $2.5 \times 10^{5}, 5 \times 10^{5}$ and $1 \times 10^{6}$ responder lymph node cells were cultured together with $5 \times 10^{5} 2500$ rad $X$-irradiated stimulator thymocytes. Cultures were set up in quintuplicate in $200 \mu \mathrm{l}$ volumes of culture medium supplemented with $15 \%$ heatinactivated $\mathrm{BN}$ serum and $5 \times 10^{-5} M 2-\mathrm{ME}$. Control cultures contained either responder or stimulator cells alone or syngeneic stimulator and responder cells. After 4 days of culture in $5 \% \mathrm{CO}_{2}$ in air at $37^{\circ} \mathrm{C} 0.15 \mu \mathrm{Ci}{ }^{14} \mathrm{C}$-thymidine (Radiochemical Centre, Amersham, England; specific activity reduced to $40 \mu \mathrm{Ci} / \mathrm{mmol})$ was added per well. Incubation was continued for 24 hours when the cells were harvested semi-automatically onto glassfiber filters. The filters were dried, immersed in $5 \mathrm{ml}$ toluene/PPO/POPOP (19) and the uptake of ${ }^{14} \mathrm{C}$-thymidine was determined in a liquid scintillation counter.

\section{Cell-mediated cytotoxicity}

Lymphocyte-mediated cytotoxicity assays were performed essentially as described by STROM et al. (27). Lymphoid effector $T$ cells were obtained from the spleen after elimination of contaminating erythrocytes with $\mathrm{NH}_{4} \mathrm{Cl}$-solution and passage over a nylon wool column. Ten to 200-fold excesses of effector cells were incubated with $2.5 \times 10^{4}{ }^{51} \mathrm{Cr}$-labeled target cells. Cultures were carried out in triplicate in plastic tubes (Falcon \# 3058, Bexton-Dickinson, 
Naarden, the Netherlands) in a $1.0 \mathrm{ml}$ volume of culture medium supplemented with $10 \%(v / v)$ IFCS. Effector and target cell mixtures were incubated for $30 \mathrm{~min}$ at $37^{\circ} \mathrm{C}$ and centrifuged for $5 \mathrm{~min}, 40 \times \mathrm{g}$ at room temperature. Incubation was continued for 5.5 hours in $5 \% \mathrm{CO}_{2}$ in air at $37^{\circ} \mathrm{C}$ on a rocking platform (Bellco, Vineland, New Yersey; 5 cycles/min). Control cultures contained target cells incubated with nylon wool purified spleen cells from unmodified $\mathrm{BN}$ donors. Spontaneous ${ }^{51} \mathrm{Cr}$ release was measured from cultures of target cells incubated alone; maximal isotope release was determined after two cycles of freezing and thawing of target cells. At the end of the incubation period tubes were centrifuged $10 \mathrm{~min}, 400 \times \mathrm{g}$ at $4^{\circ} \mathrm{C}$ and $0.75 \mathrm{ml}$ supernatant was removed to another tube for counting in a $\gamma$-counter. The percentage specific ${ }^{51} \mathrm{Cr}$ release from target cells was calculated from the following formula (after subtraction of spontaneous release value (cpm) from values obtained by incubations) :

Experimental incubation (cpm)-Control incubation (cpm) Freeze-thaw incubation (cpm)

\section{Antibody-dependent complement-mediated cytotoxicity}

Complement-dependent cytotoxic antibodies were determined according to a modified version ( 7 ) of the method of THOENIS (30). Twenty $u l$ volumes of a doubling dilution series of antiserum in BB were mixed with $5 \times 10^{5}{ }^{51} \mathrm{Cr}$-labeled target cells contained in $20 \mu \mathrm{BB}$ and $20 \mu \mathrm{l}$ of fresh rat serum or of a $1: 2$ dilution of agarose-absorbed guinea pig complement (8). The mixtures were incubated for one hour in $13 \times 75 \mathrm{~mm}$ plastic tubes (Thovadec \# 524, Nieuwkoop, the Netherlands) at $37^{\circ} \mathrm{C}$. Assays were performed in duplicate. Background $57 \mathrm{Cr}$-release was measured from tubes containing target cells incubated with complement only. Maximal ${ }^{51} \mathrm{Cr}$ release was determined from cultures in which test serum was substituted by rabbit anti rat lymphocyte serum and from tubes containing target cells with $2.04 \mathrm{ml}$ distilled water as well as from tubes containing target cells twice frozen and thawed; all maximal release values were averaged. Complement-mediated lysis was terminated by addition of $2 \mathrm{ml}$ of an $8 \mathrm{mM}$ EDTA solution in PBS at $4^{\circ} \mathrm{C}$. Cells and debris were pelleted for $10 \mathrm{~min}, 400 \times \mathrm{g}$ 
at $4^{\circ} \mathrm{C}$ and one $\mathrm{ml}$ of supernatant was subsequently removed for counting in a $\gamma$-counter. Alternatively, supernatant collection was performed according to the method of HirsCHBERG et al. (16). Here dilutions of testserum, target cells and complement were incubated in the wells of microtiter plates (Linbro \# MRC 96, Hamden, Connecticut). Maximal isotope release was determined from wells containing target cells plus $180 \mu \mathrm{ll} 5 \%$ Cetavlon (ICI, Alderly Park, Great Britain) in destilled water. After incubation for $60 \mathrm{~min}$ at $37^{\circ} \mathrm{C}$ the volume of each well was made up to $200 \mu \mathrm{l}$ with cold $8 \mathrm{~m} M$ EDTA in PBS. Microtiter plates were centrifuged $10 \mathrm{~min}, 400 \times \mathrm{g}$ at $4^{\circ} \mathrm{C}$ and 160 s supernatant of each well was absorbed by a cellulose acetate cartridge (Skatron, Lierbyen, Norway). Cartridges were removed to counting tubes and the amount of ${ }^{51} \mathrm{Cr}$ absorbed from the supernatant was determined in a $\gamma$-counter. The percentage specific ${ }^{51} \mathrm{Cr}$-release from target cells was calculated from the following formula :

Experimental incubation (cpm) - Background incubation (cpm)

Maximal release incubation (cpm) - Background incubation (cpm)

\section{Hemagglutination}

\subsection{Alloantisera}

Direct Assay. Alloantisera to be tested in the direct hemagglutination assay were heat-inactivated and doubling dilutions were prepared in $0.1 \%(\mathrm{w} / \mathrm{v})$ bovine serum albumin (Cohn fraction $\mathrm{V}$, Sigma, St. Louis) in saline pH 7.4 (SA). Erythrocytes were obtained from defibrinated blood after buffy coat depletion, washed $5 \times$ in SA and packed cells diluted to a $2 \%(v / v)$ suspension. Fifty $\mu \mathrm{l}$ erythrocyte suspension and $25 \mu \mathrm{l}$ diluted antiserum were incubated for $30 \mathrm{~min}$ at room temperature in round bottom $11 \times 55 \mathrm{~mm}$ glass tubes. Tubes were centrifuged for $10 \mathrm{~min}$ at $200 \times \mathrm{g}$ and the pellets were screened for aggregates using a microscope at low magnification.

The direct hemagglutination assay detected IgM hemagglutinins only. This was demonstrated by passing $3 \mathrm{ml}$ of a late $\mathrm{BN}$ anti LEW-E antiserum over a G-200 Sephadex column (5). This alloantiserum had a titer of 16 in the direct, and of 64 in the indirect 
hemagglutination assay. The G-200 column elution curve and fractions pooled are shown in Fig. III. 1. Fractions were concentrated by ultrafiltration and the protein content was determined by the Follin method using an IgG preparation as a reference. Alloantibodies detected by the direct assay appeared predominantly in the exclusion volume. Reduction of fraction I with 2-ME abolished the activity detected by the direct assay; the reduced fraction $I$ did not give a positive reaction in the indirect assay. Therefore, the direct assay was considered to detect $\operatorname{IgM}$ alloantibodies only.

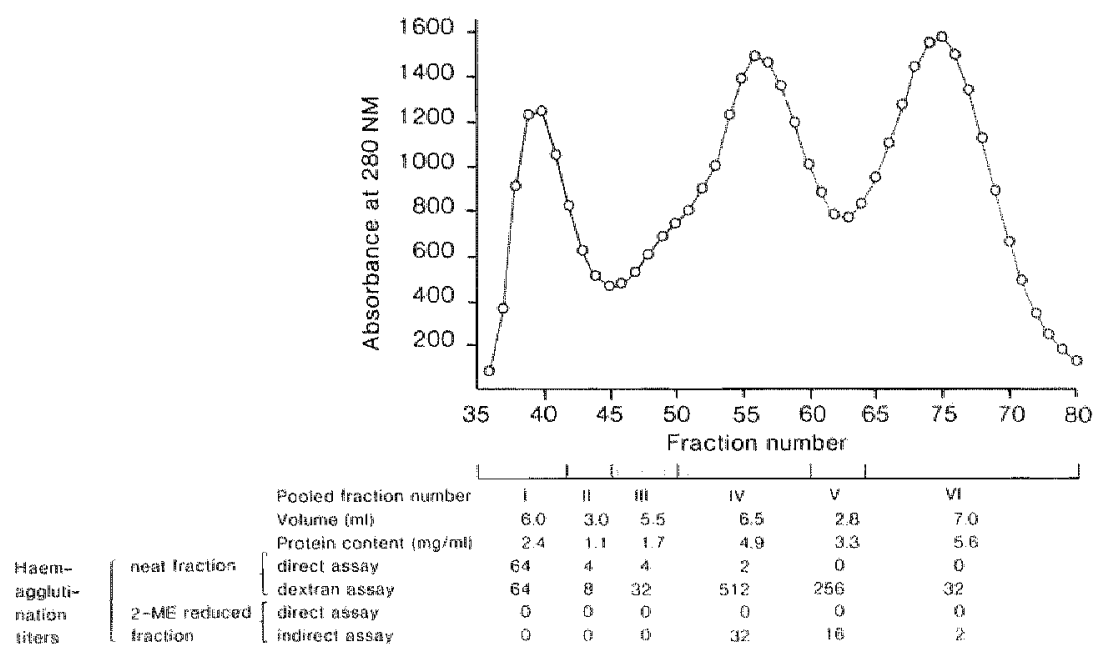

FIG. III.1. Elution curve of late BN anti LEW-E antiserum passed in the ascending way over a $G$-200 Sephadex column.

Fractions eluted from the column were pooled, concentrated, dialysed against PBS pH 7.3 and tested for hemagglutinins in the direct, indirect and dextran hemagglutination assays.

Indirect assay. Alloantisera to be used in the indirect hemagglutination assay were reduced with 2-ME. Equal volumes of serum and $0.1 M 2-\mathrm{ME}$ in PBS pH 7.3 were mixed and incubated for $60 \mathrm{~min}$ at $30^{\circ} \mathrm{C}$. Reformation of crosslinks was prevented by acetylation of sulphide residues with $5 \mu \mathrm{l} 1.2 \mathrm{M}$ iodoacetamide per $50 \mu 12-\mathrm{ME}$ solution. Doubling dilutions of reduced antiserum 
were incubated with erythrocytes in $11 \times 55 \mathrm{~mm}$ round bottom glass tubes. After incubation for 30 min erythrocytes were washed three times in $2.0 \mathrm{ml}$ of SA. Supernatants were removed and $25 \mu \mathrm{l}$ diluted rabbit IgG anti rat IgG (see Section 13.3) was added to the tubes followed by $25 \mu$ IFCS diluted $1: 4$ in SA. Rabbit IgG anti rat $\operatorname{IgG}$ had been titrated previously to ensure that anti rat lgG antibodies were present in excess. Pellets were resuspended and the erythrocytes allowed to sediment at room temperature. Hemagglutination was read macroscopically.

The indirect hemagglutination assay detected IgG hemagglutinins only. Pooled fractions IV and V obtained by G-200 separation of late BN anti LEW alloantisera as described under 'Direct assay' contained most of the antibodies detectable with the indirect assay. The use of rabbit IgG anti rat IgG-Fc in this assay yielded the same titers as obtained with rabbit IgG anti rat IgG. In addition, fraction IV showed hemagglutinin activity in the direct assay; since this activity was abolished by $2-\mathrm{ME}$ treatment it was ascribed to IgM alloantibodies contaminating this fraction. Thus the indirect assay was concluded to detect IgG alloantibodies only (Fig. III.1).

Dextran assay. Hemagglutination assays were performed in the presence of Dextran according to the method of GüNTHER et al. (14). Doubling dilutions of $100 \mu \mathrm{l}$ heat-inactivated allo-antiserum were prepared in a $2 \%(\mathrm{w} / \mathrm{v})$ solution of Dextran (Serva, Heidelberg, F.R.G.; MW 150.000-200.000). Erythrocytes were washed three times in PBS and a $0.5 \%(\mathrm{v} / \mathrm{v})$ suspension was prepared in PBS supplemented with $50 \%$ normal rat serum. Antiserum dilutions and $50 \mu \mathrm{l}$ of erythrocyte suspension were incubated in $11 \times 55$ round bottom glass tubes for two hours at $37^{\circ} \mathrm{C}$. Pellets were gently resuspended and screened for aggregates using a microscope at low magnification.

\subsection{Xenoantisera}

Prior to testing xenoantisera were heat-inactivated and when desired reduced with 2-ME as described in Section 12.1. Doubling dilutions of $25 \mu \mathrm{l}$ antiserum were prepared in PBS in opalescent white microtiter trays (Linbro \# 76-308-05, Hamden, Connecticut). Erythrocytes were washed three times in PBS and made up 
to a $2 \%(\mathrm{v} / \mathrm{v})$ solution in the same buffer. Antiserum dilutions were mixed with $25 \mu \mathrm{l}$ of erythrocyte suspension and incubated for one hour at $37^{\circ} \mathrm{C}$. Hemagglutination was read macroscopically and checked microscopically if absorbed xenoantisera were tested for the absence of hemagglutinins.

\section{Xenoantibodies}

\subsection{Antibodies for immunohistochemistry}

Rabbit $\lg G$ anti rat $\lg M$. Rat $\operatorname{IgM}$ and IgA immunoglobulin fractions were prepared as described elsewhere (5). They were administered to rabbits made previously unresponsive to rat $\operatorname{IgG}(25)$. The antisera harvested were specific for $\operatorname{lgM}$ and $\operatorname{lgA}$ immunoglobulins in Ochterlony double diffusion and in immuno-electrophoresis when developed with whole rat serum. The IgG fraction of this antiserum was obtained by affinity chromatography on DEAE A-50 Sephadex using PBS for elution (29). The IgG fraction was next passed over a glutaraldehyde-insolubilized (2) rat IgM myelona column; the rat myeloma IgM preparation was kindly donated by Dr. H. BAzIN (University of Louvain, Brussels, Belgium). The 'fall-through" peak contained specific rabbit IgG anti rat $\mathrm{IgA}$ and the acid eluate $(0.1 \mathrm{M} \mathrm{HCl}$-glycine $\mathrm{pH} 2.8)$ contained rabbit $\operatorname{IgG}$ anti rat $\operatorname{IgM}$ only.

Rabbit antibodies to rat $\operatorname{IgG}$, rat $\operatorname{IgG}-\mathrm{Fc}$ and rat Fab fragments. Rabbit antisera against rat $\mathbb{g g}$ were prepared by immunizing rabbits every month with $1 \mathrm{mg}$ of highly purified rat IgG in Freund complete adjuvans; rabbit anti rat $\mathrm{IgG}$ immunoglobulin antisera thus prepared yielded one precipitin band in immuno-electrophoresis against whole rat serum.

Fab and Fc fragments were prepared by first incubating $100 \mathrm{mg}$ highly purified rat $\operatorname{IgG}$ in $2.4 \mathrm{ml}$ of $0.15 M$ phosphate buffer pH 7.0 with cystein $(10 \mathrm{~m} M)$ and tetra-sodium EDTA $(2 \mathrm{mM})$ dissolved in $0.24 \mathrm{ml}$ of $0.15 \mathrm{M}$ phosphate buffer pH 7.0 for $60 \mathrm{~min}$ at $37^{\circ} \mathrm{C}$. After this reduction step papain $(2 \times$ crystallized; $26 \mathrm{U} / \mathrm{mg}$; Worthington, Freehold, New Jersey) was added at an $\operatorname{lgG}$ : papain ratio of $10: 1(\mathrm{w} / \mathrm{w})$. The mixture was incubated for another 6 hours at $37^{\circ} \mathrm{C}$ and immediately passed over a $100 \times 2.5 \mathrm{~cm}$ G-100 Sephadex column in order to separate papain 
and undigested $\operatorname{IgG}$ from the $\mathrm{Fab}$ and $\mathrm{Fc}$ fragments. When the rat IgG used was isolated as described in Section 14 about $90 \%$ of the IgG was digested using the conditions specified above. The $\mathrm{Fab} / \mathrm{Fc}$ fragments harvested from the inclusion volume of the G-100 Sephadex column were next applied to a small column containing $3 \mathrm{~g}$ (frozen and dried weight) of protein A-Sepharose CL-4B (Pharmacia, Uppsala, Sweden) swollen in $0.01 \mathrm{M}$ phosphatebuffered $0.15 M$ saline $\mathrm{pH}$ 8.0. The column was washed with $0.1 \mathrm{M}$ citrate buffer $\mathrm{pH} 3.0$ and next equilibrated with $0.14 \mathrm{M}$ phosphate buffer $\mathrm{pH}$ 8.0. Fab and $\mathrm{Fc}$ fragments eluted with the equilibration buffer. $\mathrm{Fc}$ fragments retained on the column were next eluted with $0.1 M$ citrate buffer $\mathrm{pH} 6.0$ (11); this yielded about $2 \mathrm{mg}$ of $\mathrm{Fc}$ fragments. The Fc fragments were emulsified in Freund complete adjuvans at a final concentration of $0.5 \mathrm{mg} / \mathrm{ml}$ and used for raising an antiserum in a rabbit. This antiserum yielded one line in Ochterlony double diffusion against whole rat serum and yielded a strong precipitin arch against IgG but not against purified Fab fragments.

Fab fragments were isolated by exclusion chromatography on DEAE-cellulose of the 'fall-through peak' of the protein A column (which contained both Fab and Fc fragments); the Fab fragments which eluted with the equilibration buffer of $5 \mathrm{~m} M$ phosphate $\mathrm{pH} 7.6$ were harvested (I). The highly purified Fab fragments were next applied to a CM-cellulose column equilibrated with $5 \mathrm{mM}$ sodium acetate buffer $\mathrm{pH} 5.2$, conductivity $0.4 \mathrm{mS}$; next the conductive strength of the elution buffer was increased in a linear fashion and the Fab fragments which eluted with a sharp peak between 2 and $3 \mathrm{mS}$ were harvested. At a concentration of $4.5 \mathrm{mg}$ protein/ $/ \mathrm{ml}$ of Fab fragments no $\mathrm{Fc}$ fragments were demonstrable with an anti Fc serum in Ochterlony double diffusion; when subjected to polyacrylamide gel-electrophoresis in the presence of sodiumdodecyl-sulphate (SDS-PAGE) at a protein concentration of $1 \mathrm{mg} / \mathrm{ml}$ a single band at about 45.000 daltons was observed. Rabbits were immunized with these Fab fragments emulsified in Freund complete adjuvans. The antisera thus elicited gave a strong precipitin band against rat $\operatorname{lgG}$ which crossed the precipitin arch of anti $F c$ antisera in Ochterlony double diffusion. The IgG immunoglobulin fraction of rabbit anti rat Fab serum was isolated by means of affinity chromatography on DEAE A-50 Sephadex 
using $0.01 M$ phosphate buffered $0.15 M$ saline $\mathrm{pH} 7.4$ for elution. The IgG immunoglobulin fraction was next digested with pepsin by adding $1 \%(w / w)$ of pepsin (Worthington, Freehold, New Jersey in $0.1 M$ sodium acetate buffer $\mathrm{pH} 4.5$ as described by EDELMAN et al. (10). After incubation for 20 hours at $37^{\circ} \mathrm{C}$ precipitates were removed by centrifugation; next the $\mathrm{pH}$ was raised to 8.0 and the $F(a b)_{2}$ fragments were separated from undigested $\mathrm{IgG}$ and smaller fragments by exclusion chromatography on G-200 Sephadex. When desired these fragments were conjugated with fluorescein isothyocyanate (FITC); after removal of free FITC by means of exclusion chromatography on G-50 Sephadex F(ab) fractions labeled with FITC at a FITC : protein ratio between 2.5 and 3.5 were isolated by affinity chromatography on DEAE A-50 Sephadex as described by THE et al. (29).

Goat IgG anti rabbit IgG. Goat IgG anti rabbit IgG preparations were manufactured as described elsewhere (25). Before conjugation with FITC the antibodies were passed over a glutaraldehyde-insolubilized rat serum column in order to remove antibodies crossreacting with rat immunoglobulins $(24)$; when desired $F(a b)$ : fragments were prepared as described above. Goat IgG (or F(ab)e) anti rabbit IgG preparations were conjugated with FITC and used at FITC : protein ratio's between 4 and 7 .

\subsection{Antisera for erythrocyte purification}

Rabbit anti rat thymocyte antiserum was raised in rabbits as described earlier (7). For opsonization of rat leukocytes in erythrocyte suspensions the antiserum was extensively absorbed with buffy coat-depleted rat erythrocytes until void of hemagglutinins. Cytotoxicity of the absorbed serum for rat lymphocytes was determined in a ${ }^{51} \mathrm{Cr}$ release assay as described in Section 11 using rat serum as a source of complement. Eighty-nine percent of rat lymph node cells were killed at a final dilution of $1: 24$.

\subsection{Antibodies for indirect hemagglutination assays}

Rabbit IgG anti rat IgG was obtained as described in Section 13.I. Alternatively an aliquot of whole antiserum was passed over a rat IgG-CN-Sepharose $5 \mathrm{~B}$ column and absorbed antibodies were recovered by acid elution as indicated in Section 13.1. 


\section{Rat $\lg G$}

Rat IgG was prepared by precipitation of the immunoglobulins from whole rat serum with $50 \%$ ammonium-sulfate. The $\gamma$-globulins were applied to a DEAE-cellulose column (Whatman DE 52) equilibrated with $5 \mathrm{~m} M$ phosphate buffer $\mathrm{pH}$ 7.6. The eluate which contains $\mathrm{IgG}_{2 \mathrm{~A}}$ and $\mathrm{IgG}_{2 \mathrm{~B}}$ fractions (3) yielded one line in immunoelectrophoresis with rabbit antibodies to rat serum proteins.

\section{Histology and immunofluorescence}

Light microscopy. Tissues were fixed in $0.1 M$ phosphate-buffered $10 \%(\mathrm{v} / \mathrm{v})$ formaldehyde at $4^{\circ} \mathrm{C}$ and embedded in paraffin. Slices of $2-4 \mu \mathrm{m}$ thickness were deparaffinated, dehydrated and stained with hematoxylin and eosin. Preparations were enclosed in malinol. The histological changes of rejected rat renal allografts were assesssed in a blind procedure. Marginating mononuclear cells within the peritubular and glomerular capillaries were considered as intravascular changes. Interstitially located lesions consisted of mononuclear cellular infiltrate located perivascularly, periglomerularly and interstitially. Each lesion was graded semi-quantitatively using a scale from + to $+t+$. The presence or absence of vasculonecrotic changes and renal cortical necrosis was assessed qualitatively. Vasculonecrotic changes included fibrinoid deposits in the interlobular arteries, afferent arterioles and glomerular capillaries. Immunofuorescence. Tissues were frozen in isopropane cooled to $-70^{\circ} \mathrm{C}$ or in liquid freon at $-90^{\circ} \mathrm{C}$ (12). Frozen sections of 2-3 $\mu \mathrm{m}$ thickness were cut in a cryostat microtome at $-20^{\circ} \mathrm{C}$. Sections were washed with PBS, incubated with the appropriate antibody preparation, washed and - if the indirect technique was to be applied - incubated next with a second antibody preparation. Sections were washed again and enclosed in Tris-buffered glycerine pH 8.0. Controls were performed as described elsewhere (25). Immunofluorescence was assessed using a Zeiss photomicroscope equipped with a Ploem illuminator (25).

Cell suspensions were screened for surface Ig-positive cells as described in Section 7.2.1. 


\section{Statistics}

Data obtained from $\mathrm{T}$ cell-mediated cytotoxicity assays were statistically analysed using Student's (two-tailed) $t$-test. Mean titers from hemagglutination assays were calculated on the basis of the $\log _{2}$ values of the individual titers; to demonstrate differences in mean hemagglutination titers and in mean allograft rejection times of two groups Wilcoxon's midrank-sum test was used (23). 


\section{References}

1 Arend, W. P., and Silverblatt, F. J. : Serum disappearance and catabolism of homologous immunoglobulin fragments in rats. Clim. Exp. Immunol. $22: 502,1975$.

2 AVRAMEAS, $S$, and TERNYNCK, T.: The cross-linking of proteins with glutaraldehyde and its use for the preparation of immunoadsorbens. Immunochemistry 6: 66, 1966.

3 BLoch, K. J., Morse, H. C. III, and Austen, K. F. : Biological properties of rat antibodies. I. Antigen binding by four classes of anti DNP antibodies. J. Inmunol. 101: 650, 1968.

4 Bollman, J. L., Cain, J. C., and Grindlay, J. H. : Techniques for the collection of lymph from the liver, small intestine, or thoracic duct from the rat. J. Lab. Clin. Med. 33: 1349, 1948.

5 Breda VRiesman, P. J. C. Van, and Feldman, J. D. : Rat $\gamma M$ immunoglobulin : Isolation and some biological characteristics. Immunochemistry 9: 525, 1972 .

6 BREda VRIesman, P. J. C. VAN, and FELdman, J. D. : $\gamma$ M alloantibody elicited by first set renal allgrafts: in vivo and in vitro studies. J. Immunol. $108: 1188,1972$.

7 Breda Vriesman, P. J. C. Van, Swanen-Sierag, L., and Vlek, L. F. M. : Cytotoxic and enhancing properties of early $\gamma \mathrm{M}$ alloantibodies elicited by first set renal allografts. Transplantation 20:385, 1975.

8 CoHen, A., and SCHLEsinger, M. : Absorption of guinea pig serum with agar. A method for elimination of its cytotoxicity for murine thymus cells. Transplantation 10: 130, 1976.

9 Diepenhorst, P., Sprokholt, R., and Perins, H. K. : Removai of lcukom cytes from whole blood and erythrocyte suspensions by filtration through cotton wool. Vox Sang. $23: 308,1972$.

10 Edelman, G. M., and Marchalonis, J. J. : Methods used in the studies of the structure of immunoglobulins. In Merhods in Immunology and Immunochemistry, Vol. I, C.A. Williams and M. W. Chase (eds.), p. 422, Academic Press, New York, 1967.

11 Ey, P. L., Prowse, S. J., and Jenkin, C. R. : Isolation of pure $\lg G_{1}$, $\mathrm{IgG}_{\mathrm{SR}}$ and $\mathrm{IgG}_{\mathrm{gh}}$ immunoglobulins from mouse serum using Protein A-Sepharose. Inwnunochemistry 15:429, 1978.

12 Frederik, P. M., and Busing, W. M. : Freezing of tissue-limits for the autoradiographic localization of diffusable substances. $J$. Histochem. Cytochem. $27: 1520,1979$.

13 Greenberg, A. M., Sheen, L., and Medley, G. : Characteristics of the effector cells mediating cytotoxicity against antibody-coated target cells. 
Phagocytic and non-phagocytic effector cell activity against erythrocyte and tumor target cells in a ${ }^{51} \mathrm{Cr}$ release cytotoxic assay and (125)-IUdR growth inhibition assay. Immunology 29: 719, 1975.

14 CünTher, E., and STARk, O.: In The Opganisation of the Major Histocompatibility Systems in Man and Animals, D. Götze (ed), p. 207, Springer-Verlag, Berllin, 1977.

15 Handwerger, B. S., and Schwartz, R. H. : Separation of murine lymphoid cells using nylon wool columns. Recovery of the B cell-enriched population. Transplantation $18: 544,1972$.

16 Hirschberg, H., Skare, H., and Thorsery, E. : Cell-mediated lympholysis: CML. A microplate technique requiring few target cells and employing a new method of supernatant collection. $J$. Immunol. Meth. 16: 131, 1977.

17 Jullus, M. H., Simpson, E, and HerzenizerG, L. A. : A rapid method for the isolation of funcional thymus-derived murine lymphocytes. Entr. $J$. Inmumol. 3: 645, 1973.

18 Kruisbeek, A. M., Astaldi, G. C. B., Blankwater, M.-J., Zulstra, J. J., LEVERT, L. A., and ASTALDI, A. : The in vitro effect of a thymic epithelial culture supernatant on mixed lymphocyte reactivity and intracellular CAMP levels of thymocytes and on antibody production to $\mathrm{SRBC}$ by $\mathrm{Nu} / \mathrm{Nu}$ spleen cells. Cell. Immunol. 35: 134, 1978.

19 Kruisbeek, A. M., Kröse, T. C. J. M., and Zulstra, J. J. : Inerease in $T$ cell mitogen responsiveness in rat thymocytes by thymic epithelial culture supernatant. Eur. J. Immunol. $7: 375,1977$.

20 Kurnick, J. T., Ostberg, L., Stegano, M., Kimura, A. K., Om, A., and SJöBERG, O. : A rapid method for the separation of functional lymphoid cell populations of human and animal origin on PVP-silica (Percoll) density gradients. Scand. J. Imnunol. 10:563, 1979.

21 Lamener, L. D. F., Smith , J., and Mowbray, J. F. : Effect of kidney perfusion on renal allograft survival in azothioprine treated rats. Br. J. Exp. Path. 53: 130, 1972.

22 LEE, S. : An improved technique of renal transplantation in the rat. Surgery 61: 771, 1967.

23 Lehman, E. L. : Nonmarametrics: Statistical Methods based on Ranks, Hold-Day, San Francisco, 1975.

24 NeOH, S. H., JahodA, D. M., Rowe, D. S, and Voller, A. : Immunoglobulin classes in mammalian species identified by cross-reactivity with antisera to human immunoglobulin. Immanochemistry 10:805, 1973.

25 Puttie, L. B. A. van de, Brutel de la Riviere, G., and Breda Vriesman, P. J. C. VAN : Recurrent or persistant hematuria. N. Engl. J. Med. 290: 1165,1974 
26 Roos, D., and Loos, J. A. : Changes in the carbohydrate metabolism of mitogenically stimulated human peripheral lymphocytes. I. Stimulation by phytohemagglutinin. Biochim. Biophys. Acra 222: 565, 1974.

27 Strom, T. B., Carpenter, C. B., Phillips, S. M., Garovoy, M. R., and MERRILL, J P. : Rejection and enhancement in an in vitro model of alloimmunity. Transplontarion $16: 103,1973$.

28 Thakur, M. L., Coleman, R. E., and Welch, M. J. : Indium-111-labeled leukocytes for the localization of abscesses: preparation, analysis, tissue distribution, and comparison with gallium-67 citrate in dogs. J. Lab. Clin. Med. 89: 217, 1977.

29 THE, T. H., and FELTKAmP, T. E. W. : Conjugation of fluorescein isothyocyanate to antibodies. II. A reproducible method. Immonology 18 : $875,1979$.

30 Thoenes, G. H., White, E, and HildemanN, W. H. : Alloantibodies induced by weaker histocompatibility antigens in rats. J. Immunol. 104 : 1447, 1970.

31 WEINER, R. S. : Cryopreservation of lymphocytes for use in in vitro assays of cellullar immunity, J. Immunol. Meth. $10: 49,1976$. 


\section{HUMORAL RESPONSIVENESS TO ALLOGENEIC ERYTHROCYTES}

\section{Introduction}

In spite of the fact that mouse and rat erythrocytes carry antigens encoded by the MHC or their surface it is a topic of debate whether or not these erythrocytes can elicit alloantibodies. In both mice and rats allogeneic erythrocytes have been reported to be nonimmunogenic $(15,22,25,31)$; on the other hand in certain rat strain combinations antibody responses to minor histocompatibility antigens could be elicited by allogeneic erythrocytes $(8,18)$.

The immunogenicity of an antigen for a defined recipient commonly depends in part on variables such as the age of the recipient $(6,20,24)$, the amount of antigen administered $(1,21,30)$, and the route and frequency of antigen administration $(11,19)$. The effect of some of these variables on the immunogenicity of LEW-E for BN rats was assessed taking into account the age of the $B N$ recipient and the number of $L E W-E$ infused by the i.v. route. The LEW to $\mathrm{BN}$ model was chosen since this rat strain combination represents a strong histocompatibility barrier (13) and for the availability of the inbred congenic LEW. IN rat strain possessing the $\mathrm{BN}$ MHC on the LEW strain genetic background which allows a more detailed analysis of immune responses eventually elicited.

\section{On the immunogenicity of $L E W-E$ for $B N$ rats}

2.1 The effect of age of the recipient and of the antigen dose administered

The effect of age of BN rats on their capacity to produce anti LEW-E antibodies was determined by $i . v$ infusion of $1 \times 10^{10} \mathrm{LEW}-\mathrm{E}$ in $1.0 \mathrm{ml}$ PBS into recipients that were one, three or 12 months of age. Infusions were repeated twice at two-week intervals; blood samples were collected weekly and tested for the presence of hemagglutinins in the direct and indirect hemagglutination assays. 
All three months old recipients produced hemagglutinins, but in striking contrast to this finding no alloantibodies could be detected in recipients that were one month of age at the time of administration of the first infusion. Four out of 6 one year old BN rats responded to three infusions of $1 \times 10^{10}$ LEW-E by either IgM or IgG hemagglutinin production or both. In two recipients from this group alloantibodies could not be detected. The experiments on the effect of age of the BN recipients on their humoral responsiveness to LEW-E are summarized in Table IV.1.

TABLE IV.1. Influence of age on the alloantibody response of $B N$ rats to $\left.L E W-E^{1}\right)$.

Hemagglutinating alloantibody response

\begin{tabular}{|c|c|c|c|c|c|}
\hline \multirow{2}{*}{$\begin{array}{l}\text { Number of } \\
\text { LEW-E/ } \\
\text { infusion }\end{array}$} & \multirow[t]{2}{*}{$\begin{array}{l}\text { Number of } \\
\text { recipients }\end{array}$} & \multirow[t]{2}{*}{$\begin{array}{l}\text { Age in } \\
\text { months }\end{array}$} & \multicolumn{2}{|c|}{ Present ${ }^{2}$ ) } & \multirow{2}{*}{ Absent } \\
\hline & & & $\lg M$ & $\mathrm{IgG}$ & \\
\hline $10^{4}$ & 3 & 1 & $2 / 3$ & $3 / 3$ & $0 / 3$ \\
\hline $10^{10}$ & 6 & 1 & $0 / 6$ & $0 / 6$ & $6 / 6$ \\
\hline $10^{10}$ & 8 & 3 & $8 / 8$ & $6 / 8$ & $0 / 8$ \\
\hline $10^{10}$ & 6 & 12 & $3 / 6$ & $3 / 6$ & $2 / 6$ \\
\hline
\end{tabular}

1) BN rats of different ages were immunized with $1 \times 10^{8}$ or $1 \times 10^{10} \mathrm{LEW}-\mathrm{E}$. limmunizations of the same dose of $\mathrm{LEW}$-E were repeated twice at twoweek intervals; sera of the recipients were assayed weekly for hemagglutinins.

3) Recipient sera were assayed for IgM hemagglutinins by the direct, and for IgG hemagglutinins by the indirect hemagglutination assay.

The effect of the dose of LEW-E on alloantibody responsiveness of $B N$ rats was assessed by infusing three months old $B N$ rats i.v. with graded doses of LEW-E. Doses from $1 \times 10^{6}$ to $1 \times 10^{10}$ LEW-E were given in $1.0 \mathrm{ml}$ PBS, a dose of $1 \times 10^{10}$ LEW-E per $100 \mathrm{~g}$ recipient body weight was given in a corresponding volume from a suspension containing $1 \times 10^{10}$ LEW-E per ml. Infusions 
of a dose equal to the first infusion were repeated twice at two-week intervals. Blood samples were obtained by retro-orbital puncture on the 6th and 13th day after each infusion and the sera were assayed for anti LEW IgM and IgG hemagglutinins.

All BN recipients of three consecutive infusions of $1 \times 10^{8}$, $1 \times 10^{9}$ or $1 \times 10^{10}$ LEW- $\mathbb{E}$ produced hemagglutinins. Doses of $1 \times 10^{6}$ or $1 \times 10^{7}$ LEW-E elicited alloantibodies in only about half of the $\mathrm{BN}$ recipients. Only one recipient of $1 \times 10^{10}$ LEW-E per $100 \mathrm{~g}$ body weight produced IgM hemagglutinins; the other 5 rats in this group were non-responsive to LEW-E (Table IV.2). Since the highest mean titer of both IgM and IgG hemagglutinins was reached in the group that received three infusions of $1 \times 10^{8}$ LEW-E this regimen was adopted as optimal to raise anti LEW-E antibodies in adult BN rats.

TABLE 1V.2. Effect of antigen dose on the alloantibody response of $B N$ rats to $L E W-E{ }^{1}$ ).

Hemagglutinating alloantibody response

\begin{tabular}{lcccc}
\multirow{2}{*}{$\begin{array}{c}\text { Number of } \\
\text { LEW-E/infusion }\end{array}$} & $\begin{array}{c}\text { Number of } \\
\text { récipients }\end{array}$ & Present ${ }^{2}$ ) & \\
\cline { 3 - 4 } & & IgM & IgG & \\
\hline & & & & \\
\hline $10^{8}$ & 8 & $3 / 8$ & $0 / 8$ & $5 / 8$ \\
$10^{7}$ & 8 & $4 / 8$ & $5 / 8$ & $3 / 8$ \\
$10^{8}$ & 8 & $8 / 8$ & $8 / 8$ & $0 / 8$ \\
$10^{9}$ & 8 & $8 / 8$ & $7 / 8$ & $0 / 8$ \\
$10^{10}$ & 8 & $8 / 8$ & $6 / 8$ & $0 / 8$ \\
$10^{10 / 100}$ g recipient & 6 & $1 / 6$ & $0 / 6$ & $5 / 6$ \\
body weight & & & & \\
\hline
\end{tabular}

1) Three month old $B N$ rats were infused with graded doses of LEW-E. Immunizations of the same antigen dose were repeated twice at two-week intervals; sera of the recipients were weekly assayed for hemagglutinins.

2) Recipient sera were assayed for $\operatorname{IgM}$ hemagglutinins by the direct, and for IgG hemagglutinins by the indirect hemagglutination assay. 


\subsection{The kinetics of alloantibody responses}

BN anti LEW-E antibody responses elicited by three infusions of $1 \times 10^{8}, 1 \times 10^{9}$ or $1 \times 10^{10} \mathrm{LEW}-\mathrm{E}$ spaced two weeks apart showed very similar kinetics (Fig. IV.1). At 6 days after the first infusion only $\operatorname{IgM}$ hemagglutinins were demonstrable. IgM hemagglutinin titers declined thereafter up to the third infusion but 6 days thereafter a second IgM hemagglutinin peak was observed.

Significant IgG antibody production could not be demonstrated until one week after the second infusion of LEW-E. Anti LEW-E IgG hemagglutinin titers remained constant until the third infusion was given when a further rise in IgG hemagglutinin titers was noted (Fig. IV.1).

$\mathrm{BN}$ rats responding to doses of $1 \times 10^{6}$ or $1 \times 10^{7} \mathrm{LEW}-\mathrm{E}$ showed delayed anti LEw hemagglutinin responses. Antibodies were not detected before the second infusion of LEW-E and even after the third infusion neither IgM nor IgG hemagglutinins reached the titers found in recipients of infusions of $1 \times 10^{8}$ or $1 \times 10^{9} \mathrm{LEW}-\mathrm{E}$.

The only $\mathrm{BN}$ rat that responded to three infusions of $1 \times 10^{10}$ LEW-E per $100 \mathrm{~g}$ body weight produced IgM hemagglutinins by a titer of 2 only at 6 days after the second infusion.

In summary anti LEW-E IgM hemagglutinins can be optimally elicited by one infusion of $1 \times 10^{8}$ LEW-E into BN rats three months of age and $\mathrm{IgG}$ hemagglutinins can be raised by one or two further infusions of $1 \times 10^{8}$ LEW-E. One week after the third infusion a second, usually transient IgM hemagglutinin response may be observed.

FIG. IV.1. Kinetics of antibody formation of BN rats against $L E W-E$.

Six groups of 8 adult BN rats received three infusions of LEW-E at two-week intervals $(\downarrow)$. IgM hemagglutinins $(O)$ were monitored by the direct, IgG hemagglutinins ( $)$ by the indirect assay. Doses of LEW-E administered per infusion : A, $\mathbb{1} \times 10^{8} ; \mathrm{B}, 1 \times 10^{7} ; \mathrm{C}, 1 \times 10^{8} ; \mathrm{D}, 1 \times 10^{8} ; \mathrm{E}, 1 \times 10^{10}$ and $\mathrm{F}: 1 \times 10^{10} / 100 \mathrm{~g}$ bodly weight. Vertical bars represent SEM. 


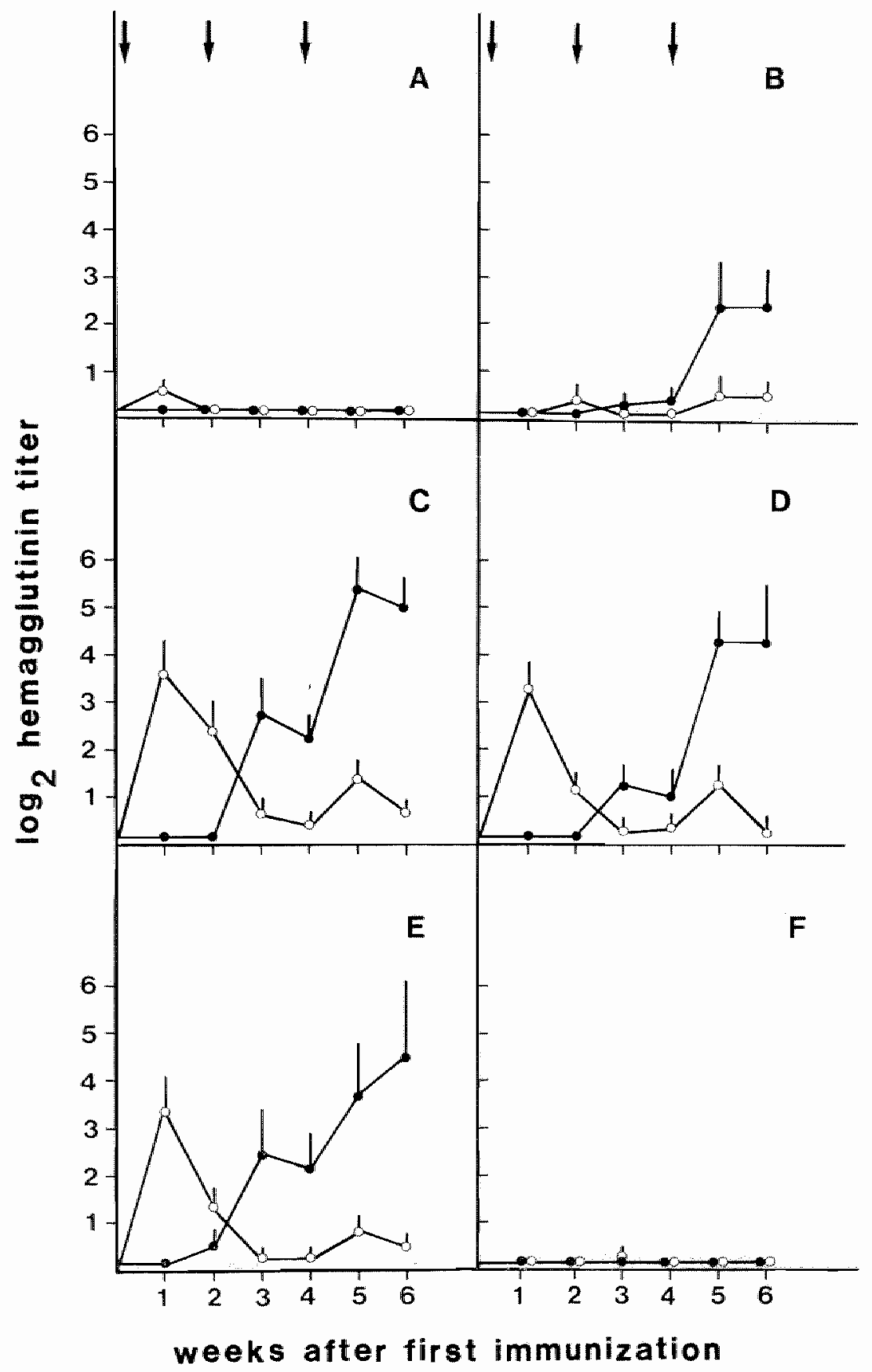




\subsection{Specificity of $B N$ anti $L E W-E$ antibodies}

In order to decide whether the BN anti LEw-E antibodies were directed against RT1. A or minor histocompatibility antigens their reactivity with erythrocytes from 13 inbred rat strains representing 12 different RTI haplotypes was measured. Both early and late alloantisera were tested. Early antisera were obtained at one week after the first, and late antisera at one week after the third infusion of $1 \times 10^{8}$ LEW-E. For comparison a RTI $^{\mathrm{In}}$ anti RTl' antiserum was tested concomitantly with the BN anti LEW-E sera. This reference serum was raised in LEW. $1 \mathrm{~N}$ rats by three i.p. injections of $2 \times 10^{7}$ LEW spleen cells administered at three-week intervals. Hemagglutinins were assayed by the dextran hemagglutination test.

Both late BN anti LEW-E antiserum and the reference serum agglutinated LEw-E by a titer of 4096. Erythrocytes from LEW.1A, LEW.1D, BD VII, LEW.1F, TO, and LEW. $1 \mathrm{~W}$ rats reacted strongly with late BN anti LEW-E serum and the reference antiserum; titers obtained ranged from 64-1024. With MNR-E a titer of 32 was obtained with late BN anti LEW-E serum and of 4 with the reference serum.

The reference serum and late BN anti LEW-E serum differed in terms of specificity. Erythrocytes from BUF, HO, KHW, and LEW.IN rats were not agglutinated by the reference serum but reacted with late $\mathrm{BN}$ anti LEW-E serum in titers ranging from 8-32. BN-E syngeneic to the antserum producers were not agglutinated (Table IV.3).

Early $B N$ anti LEW-E antiserum hemagglutinated erythrocytes of the 14 rat strains in a pattern identical to that observed using late antiserum. Titers obtained with the early antiserum were equal to or at most reduced by 3 titer units when compared to the titers obtained with late antiserum.

$B N$ anti LEW-E antibodies are therefore directed at least in part to RTI.A antigens for two reasons. First, the strong reactivity of the reference serum (directed to $\mathrm{RTI}^{\mathrm{l}}$ antigens only) with erythrocytes from 6 rat strains was also observed with BN anti LEW-E antiserum. Second, reactivity of BN anti LEW-E antiserum was strong with LEW.1A, LEW.1D, LEW.1F, and LEW.1W-E but weak with LEW.1N-E. Since these rat strains all carry the LEW genetic 
background strong reactivity must result from crossreactivity of BN anti LEW-E antibodies with various RTI antigens. On the other hand, the weak reaction of BN anti LEW-E antiserum with LEW. $1 \mathrm{~N}$ erythrocytes demonstrated that antibodies were also directed to LEW-E-associated antigens not coded for by the RT1 complex.

TABLE IV.3. Hemagglutinin acitivity of representative early and late $B N$ anti $L E W$-E sera and $L E W .1 N$ anti $L E W$ spleen cell serum with erythrocytes from different rat strains ${ }^{1}$ ).

\begin{tabular}{|c|c|c|c|c|c|}
\hline \multirow{3}{*}{$\begin{array}{l}\text { Rat } \\
\text { strain }\end{array}$} & \multirow{3}{*}{$\begin{array}{c}\text { RTII } \\
\text { haplotype }\end{array}$} & \multirow{3}{*}{$\begin{array}{c}\text { Genetic } \\
\text { background }\end{array}$} & \multicolumn{3}{|c|}{ Hemagglutination titer (degree) ${ }^{3}$ ) } \\
\hline & & & \multicolumn{2}{|c|}{ BN anti LEW-E } & \multirow{2}{*}{$\begin{array}{l}\text { LEW.IN } \\
\text { anti LEW } \\
\text { spleen cells }\end{array}$} \\
\hline & & & early & late & \\
\hline LEW.1A & a & LEW & $1024(t)$ & $1024(+)$ & $512(+)$ \\
\hline BUF & $\mathrm{b}$ & BUF & $16( \pm)$ & $32(+)$ & 0 \\
\hline $\mathrm{HO}$ & $\mathrm{c}$ & $\mathrm{HO}$ & $16( \pm)$ & $16(+)$ & 0 \\
\hline LEW.1 D & $d$ & LEW & $128(+)$ & $1024(+)$ & $512(+)$ \\
\hline BD VIII & $\mathrm{e}$ & BD VII & $64(+)$ & $128(+)$ & $64(+)$ \\
\hline LEW.1F & $f$ & LEW & $256(1)$ & $1024(+)$ & $512(-1-)$ \\
\hline $\mathrm{KHW}$ & h & KHW & $8(t)$ & $32(-1)$ & 0 \\
\hline LEW & 1 & LEW & $512(\%)$ & $4096(+)$ & $4096(+)$ \\
\hline MNR & $\mathrm{m}$ & MNR & $4( \pm)$ & $32(+)$ & $4(-5)$ \\
\hline $\mathbb{L E W} .1 \mathrm{~N}$ & $\mathrm{n}$ & LEW & $8( \pm)$ & $16( \pm)$ & 0 \\
\hline$B N$ & $\mathrm{n}$. & $\mathrm{BN}$ & 0 & 0 & 0 \\
\hline TO & $\mathrm{t}$ & TO & $128(+)$ & $64(+)$ & $256(+)$ \\
\hline LEW.IN & $\mathbf{u}$ & LEW & $64( \pm)$ & $64(+)$ & $64(+)$ \\
\hline
\end{tabular}

2) Early and late $B N$ anti LEW-E alloantisera were obtained from BN rits at one week after the first and third infusion of $1 \times 10^{8} \mathrm{LEW}-\mathrm{E}$ respectively administered at two-week intervals. LEW.IN anti LEW spleen cell serum was raised by three i.p. injections of $2.10^{7}$ spleen cells spaced 3 weeks apart.

3) Hemagglutinin activity was determined by the dextran hemagglutination assay. Degree: strongest hemagglutination obtained; $t$, strong; \pm , faint. 


\section{Restricted immunogenicity of allogeneic erythrocytes}

To determine whether BN anti LEW-E antibody responses were elicited because LEW-E were uniquely immunogenic to BN rats three months old BN rats were infused every 14 days with $1 \times 10^{8}$ erythrocytes obtained from LEW.IN, SPRAGUE-DAWLEY, WISTAR or F344 rats. The histocompatibility barriers for erythrocyte-associated antigens between $\mathrm{BN}$ rats and these donors are presented in Table II.I. Hemagglutinins were assayed by the direct and indirect hemagglutination assays unless indicated otherwise.

Of all 4 types of erythrocytes infused into $\mathrm{BN}$ rats only erythrocytes from SPRAGUE-DAWLEY rats elicited IgM and IgG hemagglutinin responses of similar magnitude as did LEW-E. However, in contrast to the kinetics of the response of $B N$ rats against LEW-E, IgM hemagglutinins were not detected until one week after the third immunization. IgG hemagglutinin production was detected first at 13 days after the second immunization.

F344-E elicited only very low-titered hemagglutinin responses in $\mathrm{BN}$ rats. Five out of $6 \mathrm{BN}$ recipients produced $\operatorname{IgM}$ and three out of 6 IgG hemagglutinins, but titers did not exceed 2 .

WISTAR-E elicited low-titered IgM hemagglutinin production in only two out of $6 \mathrm{BN}$ recipients. Surprizingly, $\operatorname{IgM}$ titers had risen in 5 out of 6 recipients at two weeks after the third infusion of WISTAR-E. Thus, all BN recipients of WISTAR-E were immunized once more with a dose of $1 \times 10^{8}$ WISTAR-E at 14 days after the third immunization. At 6 days after this last infusion hemagglutinins were demonstrable in all 6 recipients. At this time $\operatorname{lgM}$ hemagglutinin titers ranged from 4-32, IgG hemagglutinin titers from 0-16.

After immunization of BN rats with LEW.IN-E no antibody activity against LEW. IN-E was detected. However, using the dextran hemagglutination assay antibodies reactive with erythrocytes from strains with LEW, BUF, HO, BD VII, KHW, and MNR genetic background were found (Table IV.4).

This experiment showed that erythrocytes from other rat strains than LEW can elicit hemagglutinins in $\mathrm{BN}$ rats. The non-RTI alloantigenic system to which $\mathrm{BN}$ anti LEW-E antibodies were in part directed may be immunogenic by itself since LEW. $1 \mathrm{~N}-\mathrm{E}$ elicited antibodies in BN rats showing broad cross-reactivity to erythrocytes from other rat strains. 


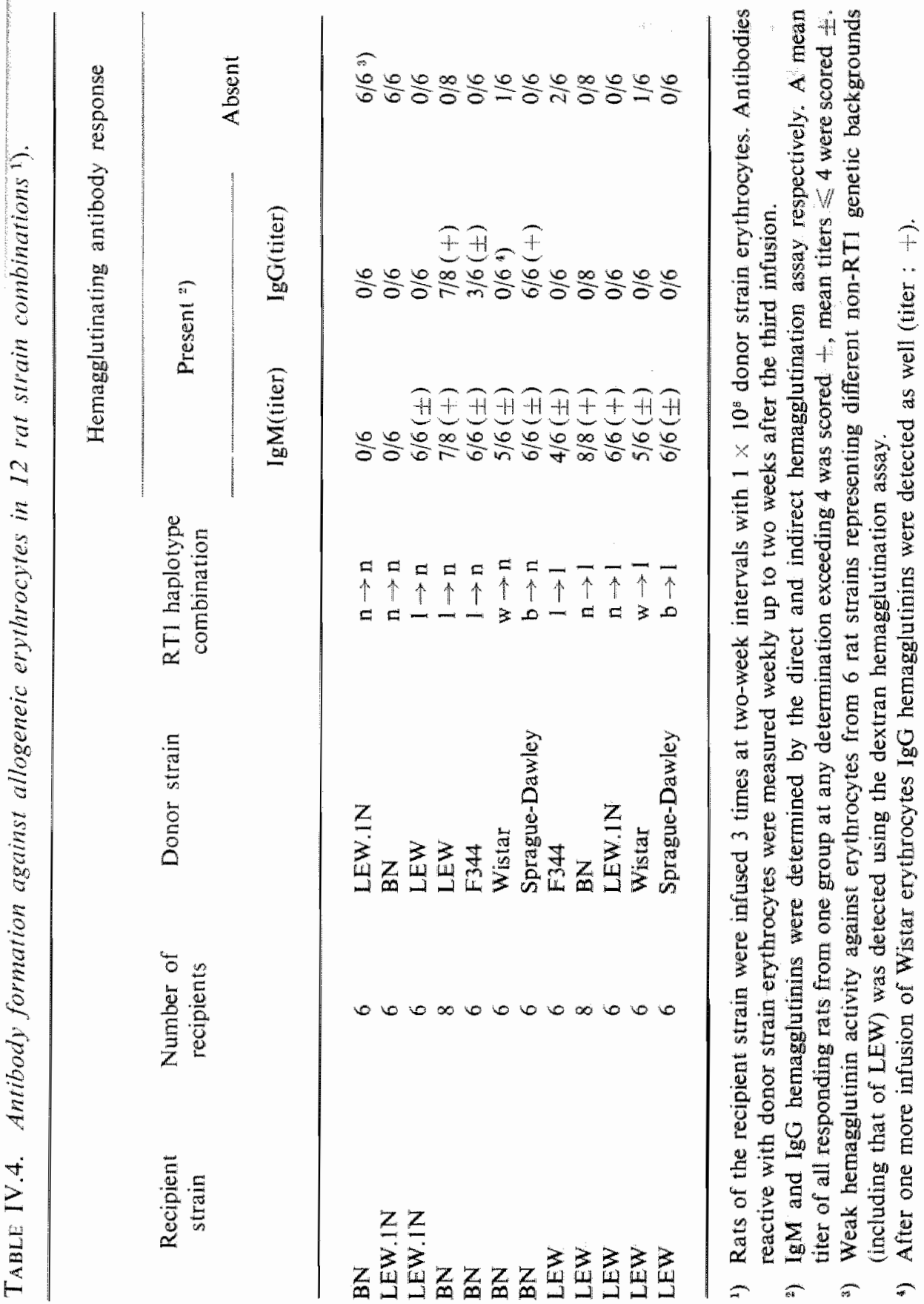




\section{Restricted responsiveness to allogeneic erythrocytes}

In order to rule out that the ability to manufacture antibodies to allogeneic erythrocytes was restricted to BN rats only LEW.IN and LEW rats were used as recipients of three doses of $1 \times 10^{8} \mathrm{BN}$, LEW.1N-, F344-, WISTAR- Or SPRAGUE-DAWLEY-E.

LEW.IN rats produced only trace $\operatorname{IgM}$ hemagglutinins in response to LEW-E. This finding is in marked contrast to the significant $\operatorname{IgM}$ and $\operatorname{IgG}$ hemagglutinin responses elicited by LEW-E in BN rats. BN-E did not elicit antibodies in LEW.IN rats.

For the LEW anti BN-E model the influence of the dose of $B N-E$ administered on their immunogenicity for LEW rats was studied. Three months old LEW rats were infused i.v. with $1 \times 10^{7}, 1 \times 10^{8}$, $1 \times 10^{9}$ or $1 \times 10^{10} \mathrm{BN}-\mathrm{E}$; infusions of the same dose of $\mathrm{BN}-\mathrm{E}$ were repeated twice spaced two weeks apart.

All LEw recipients of doses of $1 \times 10^{8}$ to $1 \times 10^{10} \mathrm{BN}-\mathrm{E}$ responded strongly by $\operatorname{IgM}$ hemagglutinin production at one week after the first infusion of BN-E but continued immunizations did not elicit IgG hemagglutinins. LEW recipients of doses of $1 \times 10^{9}$ or $1 \times 10^{10}$ LEW-E responded to the third, but only weakly or not to the second infusion of $\mathrm{BN}-\mathrm{E}$ by a second peak of IgM hemagglutinin production (Fig. IV.2). Specificity of the hemagglutinins elicited was assessed by the dextran hemagglutination assay to be restricted to RT1" antigens.

F344-, WISTAR-, and SPRAGUE-DAWLEY-E elicited only weak IgM hemagglutinin responses in LEW rats. IgG hemagglutinins were not demonstrable up to two weeks after the third infusion of allogeneic erythrocytes.

This second experiment demonstrated that allogeneic erythrocytes may elicit antibodies in rat strains different from the BN strain. However, in contrast to BN recipients, LEW.1N and LEW rats responded to allogeneic erythrocytes with $\operatorname{IgM}$ hemagglutinins only.

\section{Discussion}

In this study, antibody formation against RTI.A region-encoded antigens was reproducibly elicited by immunization of the recipient with allogeneic erythrocytes. Antibodies to minor histocompatibility antigens can be raised by repeated immunization of rats with allogeneic erythrocytes (18) but this antigen was purported not to 


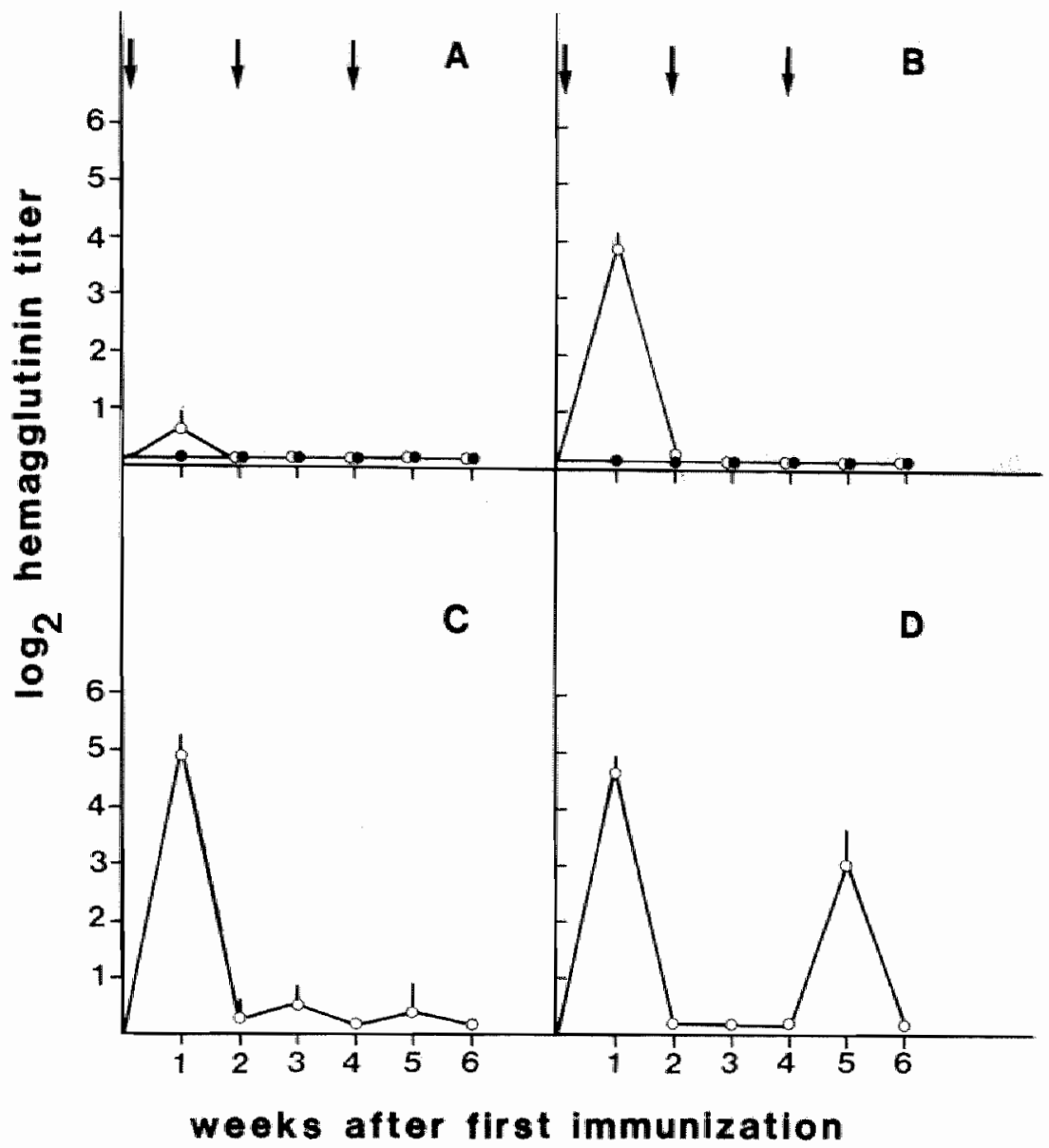

FIG. IV.2. Kinetics of antibody formation of LEW rats against $B N-E$.

Four groups of 8 adult LEW rats received 3 infusions of BN-E at wo-week intervals $(\downarrow)$. IgM hemagglutinins $(O)$ were monitored by the direct, IgG hemagglutinins ( by the indirect assay. Doses of BN-E administered per infusion: $\mathrm{A}, 1 \times 10^{7} ; \mathrm{B}, 1 \times 10^{8} ; \mathrm{C}, 1 \times 10^{9}$ and $\mathrm{D}, 1 \times 10^{10}$. Vertical bars represent SEM.

elicit antibody formation against RT1.A region-encoded antigens $(15,3 l)$, notwithstanding their presence on the erythrocyte membrane $(5,12)$.

Allogeneic leukocytes that may be present in purified erythrocyte suspensions could be argued to account for the hemagglutinating 
antibody responses detected in our studies. However, as pointed out in Chapter III, purified erythrocyte suspensions contained less than one leukocyte per $1 \times 10^{8}$ erythrocytes and this amount of erythrocytes sufficed to elicit alloantibody formation. Furthermore, residual leukocytes present in erythrocyte suspensions may be assumed to be opsonized by rabbit anti rat leukocyte antibodies and complement during the purification procedure. Opsonized leukocytes have been shown to be removed efficiently from the circulation by the reticuloendothelial system of the host (3).

Differences in the immunization protocols used by other investigators and us may explain the differing results obtained. The dose of erythrocytes used for immunization was about $2.5 \times 10^{8}$ in the study of WELSH et al. (3l) and $5 \times 10^{9}$ in the study of HEsLOP and HesLop (15). In our hands, a dose range of $1 \times 10^{8}-1 \times 10^{10}$ erythrocytes was immunogenic in both the BN anti LEW and the reciprocal combination. Therefore the failure to elicit alloantibody is not likely to depend on the antigen dose administered.

Both Wrash et al. and HesLop and Heslop immunized their recipients of allogeneic erythrocytes by the i.p. ronte whereas we infused our recipients intravenously. The route of immunization may greatly influence immune responsiveness of the recipient (II). However, BN anti LEW and LEW anti BN hemagglutinin responses were equally efficiently elicited by intraperitoneal administration of $1 \times 10^{8}$ allogeneic erythrocytes (Data not shown). Thus, different protocols applied are not likely to explain the failure of others to elicit antibody responses to allogeneic erythrocytes.

Consequently, the different strain combinations used in all three studies are most likely to account for the different responses observed. Indeed, the magnitude of the alloantibody response to RTI incompatible erythrocytes was markedly different depending on the strain combination used (Table IV.4). Apart from qualitative differences that will be discussed below, quantitative differences may be due to varying density of RTI.A antigens on the erythrocyte membrane among different rat strains (14).

Although strong hemagglutinin responses could be elicited by allogeneic erythrocytes depending on the dose and age of $\mathrm{BN}$ recipients, unresponsiveness to LEW-E could be induced as well. Unresponsiveness was frequently observed in $\mathrm{BN}$ rats infused with doses of $1 \times 10^{6}$ or $1 \times 10^{7}$ LEW-E. Possibly administration 
of the first dose of LEW-E induced a state of 'low-zone' tolerance, depressing responsiveness to subsequent immunizations in these recipients $(I, 7,2 I)$. Induction of 'low zone' tolerance to particulate antigens has been documented in mice (27).

Unresponsiveness of BN rats to LEW-E was also observed after infusion of $1 \times 10^{10} \mathrm{LEW}-\mathrm{E} / 100 \mathrm{~g}$ body weight of the recipient or after infusion of $1 \times 10^{10}$ LEW-E into $\mathrm{BN}$ rats one month of age. Non-responsiveness in the latter recipients was not due to immunoincompetence of these young rats since infusion of $1 \times 10^{8} \mathrm{LEW}-\mathrm{E}$ elicited both $\operatorname{lgM}$ and $\operatorname{lgG}$ hemagglutinins. Since $\mathrm{BN}$ rats weigh about $100 \mathrm{~g}$ by one month of age infusion of $1 \times 10^{10}$ LEW-E into these rats is comparable to the infusion of $1 \times 10^{10} \mathrm{LEW}-\mathrm{E} / 100 \mathrm{~g}$ body weight in adult rats. Therefore, the same mechanism is supposed to account for the unresponsiveness observed in young and adult rats; the nature of the mechanism involved has been studied in detail (See Chapter V).

$B N$ anti LEW-E antibody responses elicited by infusions of $1 \times 10^{8}$ LEW $-\mathbb{E}$ followed an almost classical pattern of antibody formation. The first infusion elicited exclusively $\operatorname{IgM}$ hemagglutinins; after the second infusion IgG hemagglutinins were detected as well. Surprizingly, a second raise in $\operatorname{IgM}$ hemagglutinin titers was noticed at one week after the third infusion of LEw-E. This secondary IgM response was not likely to be elicited by LEW-Eassociated antigens not recognized by the host in the first and second inoculum of LEW-E (18) since reactivity of early and late BN anti LEW-E antisera with erythrocytes from various rat strains exhibited identical specificity patterns. Secondary BN anti LEW IgM hemagglutinin responses might be explained as follows. Using lipopolysaccharide as an antigen, $\lg \mathrm{M}$ antibody responses have been demonstrated to be depressed by $\lg$ antibodies directed to this antigen (29). At the time of the second infusion of $1 \times 10^{8}$ LEW-E into BN rats IgM antibodies may have been present which becaluse of low avidity (29) did not bind to the antigen administered. Consequently, these antibodies remained available to suppress a secondary IgM response to the second inoculum of LEW-E. At the time of the third immunization with LEW-E IgM antibody titers were generally low; moreover, their avidity may have been increased. Thus, in contrast to the situation found at the time of the second infusion, IgM antibody may not have been available for the sup- 
pression of a secondary $\operatorname{IgM}$ response to the third infusion of LEW-E.

The magnitude of the hemagglutinin responses elicited by infusions of $1 \times 10^{8}$ LEW-E in BN rats varied considerably within one experiment. Immune responsiveness did not depend on the status of viral infection of $\mathrm{LEW}-\mathrm{E}$ donors and $\mathrm{BN}$ recpients (17) since $\mathrm{BN}$ anti $L E W-E$ antibody formation was reproducible using rats reared under SPF conditions (Data not shown). Although physical health of the recipient may influence the magnitude of its immune response to an antigen (10) the fact that inbred rats are homogeneous for transplantation antigens only suggests that genes outside the MHC also influence immune responsiveness.

BN anti LEW-E antibodies were directed to RTI.A antigens and to one or more minor alloantigenic systems. The RT2 minor alloantigenic system cannot be involved since the $\mathrm{BN}$ rat strain of Maastricht was typed to carry the RT2 allele (26) which is compatible with the RT2 allele of LEW rats. Involvement of the RT3 minor alloantigenic system is possible because LEW-E express antigens coded for by the RT3 ${ }^{\mathrm{a}}$ allele, which is absent from the BN strain. However, assuming reactivity of BN anti LEW-E antisera against erythrocytes from various rat strains that were not agglu-

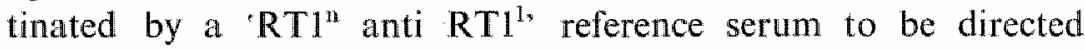
against one minor system only this alloantigenic system can be excluded to represent RT3 since both BUF (not RT3 ${ }^{\mathrm{a}}$ )- as well as $H O\left(R T 3^{n}\right)$-E were agglutinated. Hence, the minor alloantigenic system cletected is probably a newly discovered one, but needs further characterization and confirmation by other investigators before receiving designation in rat histocompatibility nomenclature (9).

Comparison of the hemagglutinin responses elicited by erythrocytes derived from various rat strains in $B N$ and LEW recipients revealed that F344-, WISTAR-, SPRAGUE-DAWLEY-, and LEW-E elicited both IgM and IgG hemagglutinins in BN rats, whereas WISTAR-, SPRAGUE-DAWLEY-, and BN-E elicited exclusively IgM hemagglutinins in LEW rats. Since the erythrocytes used for immunizations presented RTI.A-disparate histocompatibility antigens to both types of recipients, this finding reflects an advantage of the BN rat strain over the LEW strain in terms of the responsiveness to allogeneic erythrocytes. This property of the BN strain probably resided in 
genes located outside the RTI complex since LEW. IN rats responded to LEW-E with IgM hemagglutinins only. An Ir gene controlling hemagglutinin production to $\mathrm{RT}^{\text {« }}{ }^{4}$ antigens was detected in As2 rats and mapped at about $18 \mathrm{cM}$ from the $\mathrm{MHC}(16)$. However, no attempt was made in that study to differentiate between Ir gene control of IgM and IgG alloantibody responsiveness respectively.

Apart from the hypothesis that IgG antibody responsiveness of $B N$ rats to RT1 antigens presented by allogeneic erythrocytes is under Ir gene control (2), production of lgG hemagglutinins might also result from stimultaneous recognition of major and minor antigenic systems on allogeneic erythrocytes (28). Immunizations with erythrocytes using BN, LEW. IN and LEW rats either as donors or recipients revealed that the RTI.A as well as the minor alloantigenic systems present on LEW-E and LEW. $1 \mathrm{~N}$-E induced $\operatorname{IgM}$ alloantibody formation in $\mathrm{BN}$ or LEW. $1 \mathrm{~N}$ rats by themselves. Simultaneous recognition of both systems by the BN recipient might act synergistically in the activation of its immune system and induce an $\operatorname{IgM}$ to $\operatorname{IgG}$ switch in the alloantibody response (23). Since antibodies raised against the minor alloantigenic system by infusion of BN rats with LEW.1N-E cross-reacted with erythrocytes from rats having 6 different genetic backgrounds the minor alloantigenic system is probably also present on the surface of F344-, SPRAGUEDAWLEY-, and WISTAR-E. This would extend the validity of the hypothesis of 'synergistic antigenicity' to explain IgG hemagglutinin responses elicited by these types of erythrocytes in BN rats. Consequently, the failure to elicit IgG hemagglutinins in LEW rats could be due to compatibility for the minor alloantigenic system with WISTAR-, and SPRAGUE-DAWLEY-E and to the absence of a second allele of this system in the $\mathrm{BN}$ strain. An erythrocyte-associated alloantigenic system 'present on all albino strains but absent from brown rats' as described by BURHOE as early as in 1948 (4) would perfectly fit our present data. However, in contrast to the findings reported in that study we could never detect 'isohemagglutinins' in sera from unmodifed $\mathrm{BN}$ rats directed to erythrocytes derived from albino rat strains. 


\section{Summary}

Studies are presented demonstrating that allogeneic erythrocytes can elicit antibody formation against $\mathrm{RT}$.A region-encoded antigens. IgM hemagglutinins could be elicited in 11 out of 12 rat strain combinations tested including congenic strain combinations representing a RTI major histocompatibility barrier only. IgG hemagglutinins were only elicited using BN rats as recipients. Two hypotheses are presented to explain this phenomenon. In the first hypothesis, IgG responsiveness is supposed to be controlled by one or more Ir genes located outside the RT1 complex and in the second explanation by assuming that concomitant recognition of RT1 antigens and an unidentified minor alloantigenic system acted synergistically in eliciting IgG hemagglutinin responses in BN rats.

Depending on the dose of LEW-E administered to BN rats unresponsiveness to LEW-E-associated antigens could be induced as well; both 'low zone' and 'high-zone' tolerance were observed. 


\section{References}

1 BenJAmin, D. C. : Suppressor cells in tolerance to HGG : Kinetics and cross-suppression in high dose tolerance - absence in low dose tolerance. $J$. Immunol. $118: 2125,1977$.

2 Bleux, C., Ventura, M., and Liacopoulos, P. : $\lg M-\lg G$ switch-over among antibody-forming cells in the mouse. Nature 267:709, 1977.

3 Breda Vriesman, P. J. C. van, Swamen-Suerag, L., and Vlek, L. F. M. : Cytotoxic and enhancing properties of early $\gamma \mathbf{M}$ alloantibodies elicited by first set renal allografts. Transplantation $20: 385,1975$.

4 BurHoE, S. O. : Blood groups in the rat (Rattus norvegicus) and their inheritance. Proc. Nat. Acad. Sci. USA 33: 102, 1947.

5 BuTcher, G. W., and Howard, J. C. : A recombinant in the major histocompatibility complex of the rat. Nature $266: 362,1977$.

6 Callakd, R. E., Basten, A., and Blanden, R. V.: Loss of immune competence with age may be due to a qualitative abnormality in lymphocyte membranes. Nature $281: 218,1979$.

7 Fernandez, C., and Mölleir, G. : Specific antibodies are responsible for the low dose suppression of the immune response to thymusindependent antigens. Scand. J. Immunol. 7: 331, 1978.

8 Frenzl, B., Kren, $V_{\text {, }}$, and Strark, O. : Attempt to determine blood. groups in rats. Folla Biologica $6: 121,1960$.

9 GILE, T. J. III : Report on the first international workshop on alloantigenic systems in the rat. Transplant. Proc. 10:271, 1978.

10 Good, R. A., Jose, D., Cooper, W. C., Fernandes, G., Kramer, T, and YUNis, E. : Influence of nutrition on antibody production and cellular immune responses in man, rats, mice and guinea pigs. In Malmutrition and the Immune Response, R. M. Suskind (ed.), p. 169, Raven Press, New York, 1977.

11 GreEnE, M. I., and BACH, B. A. : The physiological regulation of immunity : differential regulatory contributions of peripheral and central lymphon compartments. Cell. Immunol. 45: 446, 1979.

12 GÜNTHER, E., Stark, O., and KOCH, C. : Genetic definition of 1 regiondetermined antigens of the rat major histocompatibility complex. Eur. J. Immunol, 8: 206, 1978.

13 Guttmann, R. D. : In vitro correlates of rejection. 1I. Rat mixed lymphocyte reactivity in vitro and cardiac allograft acute rejection, hyperacute or accelerated rejection, and prolongation by active immunization. Transplantation $23: 153,1977$.

14 H.ART, D. N. J., and FABRE, J. W. : Substantial strain variations in the amount of RT1-A antigens expressed on erythrocytes : potential 
problems in the use of erythrocytes for typing studies. Transplant. Proc, in press.

15 Heslop, B. F, and Heslop, H. E. : Allogenelic red blood cells fail to induce hemagglutinating antibodies or cellular alloimmunity in rats and are immunosuppressive. Transplantation $28: 144,1979$.

16 HEsLop, B. F., and JoLLY, K. D. : Genetic control of hemagglutinin production against a MHC determined alloantigen in rats. Immanogenetics $8: 567,1979$.

17 I Yanyi, P., Mourik, P. van, Breuning, M., and Melief, C. J. M. : Anti-H-2 antibodies induced by syngeneic immunization. Immanogenetics: $10: 319,1980$.

18 KuNZ, H. W., and Gill, T. J. IIII : Red blood cell alloantigenic systems in the rat. J. Immunogenetics $5: 365,1978$.

19 MATTINGLY, J. A., and WAKSMAN, B. H. : Immunologic suppression after oral administration of antigen. 1. Specific suppressor cells formed in rat Peyer's patches after oral administration of sheep erythrocytes and their systemic migration. J. Inmmonol. 121: 1878, 1979.

$20 \mathrm{McINTOSH}, \mathrm{K} . \mathbb{R}$, and SegRe, D. : B- and T-cell tolerance induction in young-adult and old mice. Cell. Immunol. 27: 230, 1976.

21 McIntosh, K. R., Segre, M., and Segre, D. : Role of suppressor T-cells in double-zone tolerance to deaggregated human gammaglobulin. Immunol Letters: I : 233, 1980.

22 Medawar, P. B. : Iso-antigens. In Biological Problems of Grafting, F. Albert and G. Lejeune-Ledant (eds.), p. 8, Blackwell, Oxford, 1959.

23 Mrtcheld, G. F. : In The lymphocyte: Structure and Funcrion. J. J. Marchalonis (ed.) p. 232. Dekker, New York, 1975.

24 NAKANO, K., and CINADER, B. : A strain survey of age-dependent changes in antigen elimination, antibody formation and tolerance. J. Immusogenetics $7: 183,1980$.

25 OweN, R. D. : In Biological Problems of Grafring, F. Albert and G. LejeuneLedant (eds.), p. 80, Blackwell, Oxford, 1959.

26 PALM, J., and BLACK, G. : Interrelationships of inbred rat strains with respect to Ag-B and non-Ag-B antigens. Transplantation 11 : $184,1971$.

27 Stumpr, R., Heuer, J, and Kölsch, E. : Suppressor T cells in low zone tolerance. I. Mode of action of suppressor cells. Eur. J. Immunol. 7 : $74,1974$.

28 SCHIERMAN, L. W., and MCBride, $\mathbb{R}$. A. : Adjuvant activity of erythrocyte isoantigens. Science 156: 658, 1967. 
29 UHR, J. W., and Möller, G. : Regulatory effect of antibody on the immune response. Adv. Immunol. $8: 81,1968$.

30 Weber, G., and KöLSCH, E. : Low zone tolerance : a possible defect in the switch from IgM to IgG production. Eur. J. Immunol. 2 : 191, 1972.

31 Welsh, K. I.; Burgos, H., and Batchelor, J. R. : The immune response to allogeneic rat platelets; $\mathrm{Ag}-\mathrm{B}$ antigens in matrix from lacking la. Eur. J. Immunol. $7: 267,1977$. 


\section{ON THE MECHANISM OF MAINTAINANCE OF UNRESPONSIVENESS BY HIGH DOSES OF LEW-E}

\section{] Introduction}

Induction of specific immunological responsiveness or unresponsiveness depends on the molecular weight and composition of the antigen particularly its state (e.g. aggregated or non-aggregated) and on the dose of antigen administered, but also depends on the age and genetic constitution of the recipient and the route by which the antigen is presented.

Depending on the combination of antigen-associated factors and recipient-dependent factors selected, different mechanisms may lead to one effect: immunological unresponsiveness to the antigen. Thus the unresponsiveness to LEW Class I alloantigens observed after infusing young $\mathrm{BN}$ rats with large numbers of LEw-E may be brought about by any of the following mechanisms.

Clonal deletion, -abortion or -inactivation. Administration of a relatively large dose of semi-allogeneic $F_{1}$ lymphocytes to a newborn or young, immunologically immature recipient induces life-long unresponsiveness to the transplantation alloantigens of the donor $(3,45)$. This unresponsiveness was thought to be mediated by elimination of clones of lymphoid cells with receptors for donor transplantation antigens because the number of specific antigenreactive $B$ cells was frequently observed to be decreased in adult animals "tolerized" according to the protocol outlined above (34). Elimination of the antigen-reactive cells prior to maturation into surface-immunoglobulin bearing $B$ cells is called clonal abortion, and elimination of antigen-reactive cells already differentiated into surface-immunoglobulin positive $B$ cells has been taken to represent clonal deletion (29). These mechanisms have been thought to be operational in the unresponsiveness of the immune system to self-determinants (45) and served as a basis for the clonal selection theory of the immune system as proposed by BURNET (5). 
According to the theory of clonal abortion or -deletion specific antigen-reactive $B$ cells should be eliminated from the bodly after encountering large amounts of antigen prior to. or just after maturation. However, recent studies indicate that in a number of models of tolerance antigen-reactive $B$ cells are not deleted but blocked in terms of manufacturing antibody due to saturation of their antigen-receptors $(I l, l 3)$. Blocking could be reversed by enzymatical dissociation of antigen-receptor complexes from the cell surface leaving - after regeneration of the cell receptors antigen-reactive $\mathrm{B}$ cells capable of responding to the antigen if presented in an immunogenic form. This mechanism has been termed 'clonal inactivation' rather than clonal deletion or -abortion.

Induction of suppressor cells. Apart from the participation of macrophages, $B$ and $T$ lymphocytes in the generation of an immune response each of these cell types has also been demonstrated to exert a negative feedback on immune reactivity. The role of macrophages in the control of immune responsiveness has mainly been studied in vitro $(8,36,47)$; the relevance of these observations to in vivo regulation of the immune response remains to be determined. Immunosuppressive activity of B lymphocytes is probably mediated by antigen-specific antibodies $(33,40)$; the role(s) of antibody in the suppression of immune responses will be outlined below.

Suppressor $\mathrm{T}$ lymphocytes represent a subset of $\mathrm{T}$ lymphocytes capable of specifically suppressing or terminating an immune response (43). This functional $T$ lymphocyte subset has been identified by cell-surface alloantigens in mouse ( $\mathrm{T}$ lymphocyte markers Ly I-, $\left.2^{+}, 3\right)(2,6)$ and by an immunoglobulin classspecific receptor $\left(T_{\gamma}\right)$ in man (3I). Although $\mathrm{T}$ cell-specific markers have been identified in the rat these have not yet been related definitively to functional $\mathrm{T}$ cell subsets $(4,39)$.

Suppressor $\mathrm{T}$ cells are probably activated as a physiological control circuit in the course of any immune response (17). Their activity may become most manifest under extreme circumstances i.e. if antigen is administered in quantities in excess of (15) or below (25) immunogenic amounts or if antigen enters the body by an unusual route $(27,44)$. Many investigators in this field assume a delicate balance to exist between 'helper' and 'suppressor' mecha- 
nisms in an immune response partially influenced by helper and suppressor T cells (17). There is good evidence that suppressor $T$ cells exert their regulatory effect on an immune response by soluble antigen-specific factors but the nature of these factors has not been completely elucidated (42).

Antibody-mediated immunosuppression. Immunological responsiveness of a host to an antigen may result in an antibody response. The antibody elicited by the antigen may subsequently exert a negative feedback on this humoral response $(14,15)$. Since this regulatory mechanism is not likely to establish longlasting immunological unresponsiveness to transplantation antigens it will not be dealt with here in detail.

Antigen-anibody complex-mediated immunosuppression. Early in the course of a humoral response to an antigen a phase may exist in which immune complexes are present in the host in the absence of detectable free circulating antigen-specific antibody. Hence, the recipient may appear to be unresponsive to the antigen. Apart from this pitfall antigen-antibody complexes have also been demonstrated to exert immunosuppressive effects $(32,35)$. An immune complex-mediated mechanism that may lead to deletion of antigenreactive cells has been suggested by HUTCHINSON and ZOLA (20). According to this hypothesis polyvalent antigens may be partially covered with antibodies but still possess binding sites for interacting with antigen-reactive cells. If such a double interaction would occur, the antigen-reactive cell would become indirectly opsonized and might be eliminated by mechanisms capable of lysing opsonized cells or sequestrating immune complexes. Thus, antigen-reactive cell opsonization could deplete the host of antigenreactive cells and thus establish antigen-specific tolerance. This hypothesis was put forward to explain the mechanism of immunological enhancement of tumour and organ graft survival (19).

Induction of anii-idiotypic antibodies. Recognition of a restricted number of immunogenic sites (epitopes) on an antigen may lead to expansion of a few clones of antigen-reactive cells. Cells from one clone will all possess identical antigen-receptors and produce antibodies with identical antigen-binding sites (idiotypes). Since 
these idiotypes were not encountered by the immune system of the host in such large quantities before an immune response against the idiotype(s) may develop resulting in the production of anti idiotypic antibodies $(I)$ or suppressor factors (4I). Like antigenantibody complexes, anti idiotypic antibodies may cause unresponsiveness in the host by blocking antigen-specific antibodies or induce tolerance by binding to the antigen receptors on antigenreactive cells, thus causing opsonization of these cells (19).

Blockade of the reticulo-endothelial system. Administration of large amounts of a particulate antigen may lead to overloading of the cells of the reticulo-endothelial system (38). This might aspecifically impair antigen-presentation by macrophages to immunocompetent lymphocytes. Furthermore, relevant to our studies was the finding that blockade of the reticulo-endothelial system by large amounts of erythrocytes may be caused by hemoglobin released within macrophages after degradation of phagocytized erythrocytes (24).

The specific immunoregulatory mechanisms described interact in a network of immunoregulatory reaction chains or circuits. Attempts are being made now to relate experimentally defined immunoregulatory processes to each other in order to reach a coherent model of the regulatory circuits involved in the control of immune responsiveness $(9,17,2 I)$.

The experiments described in this Chapter were carried out in order to decide which of the mechanisms outlined above was involved in the maintainance of unresponsiveness established in young BN rats to LEW-E-associated antigens by infusion of large amounts of LEW-E.

\section{Specificity of unresponsiveness}

To decide whether or not the unresponsiveness to LEW-E observed in $\mathrm{BN}$ rats after infusion of $1 \times 10^{10} \mathrm{LEW}-\mathrm{E}$ at one month of age was specific an immunogenic dose of $1 \times 10^{8}$ SRBC was administered two weeks later. Control BN rats were given $1 \times 10^{10}$ LLW-E at one month of age and were infused two weeks later with $1 \times 10^{8}$ LEW-E. Immunizations with $1 \times 10^{8}$ SRBC and $1 \times 10^{8}$ LEW-E respectively were repeated twice at two-week intervals. Hemagglu- 


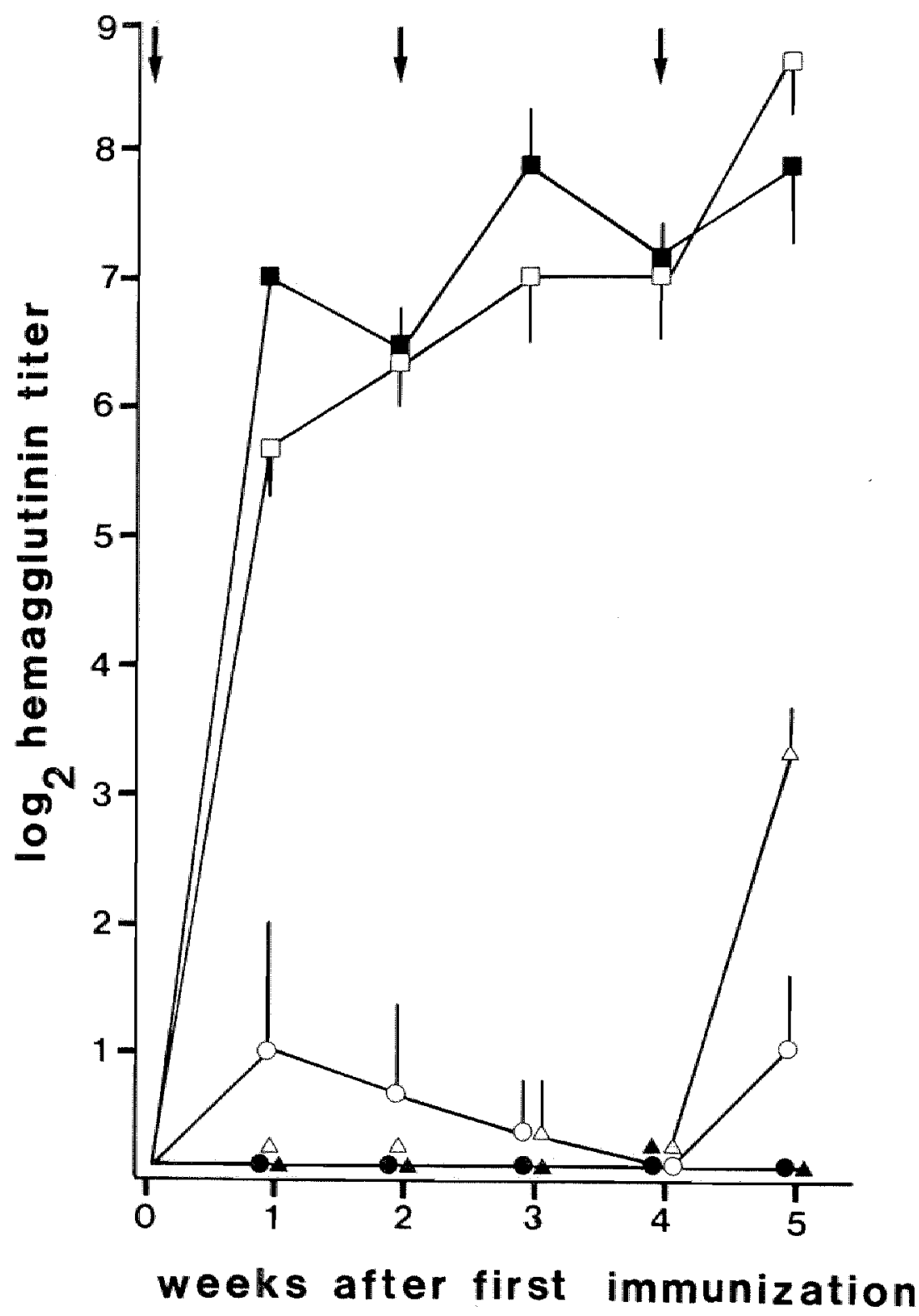


tinin responses in these recipients were compared to the responses elicited by three infusions of $1 \times 10^{8}$ SRBC or LEW-E in age-matched $\mathrm{BN}$ rats not infused with $1 \times 10^{10}$ LEW-E at one month of age. Each experimental group consisted of $6 \mathrm{BN}$ rats.

Unmodified $B N$ rats responded with hemagglutinins to infusions of $1 \times 10^{8} \mathrm{LEW}-\mathrm{E}$. This response was completely suppressed in BN rats previously infused with $1 \times 10^{10}$ LEW-E. In contrast, both in unmodified BN rats and in BN recipients of $1 \times 10^{10} \mathrm{LEW}-\mathrm{E}$ comparable hemagglutinin titers to $\mathrm{SRBC}$ were raised indicating that infusion of $1 \times 10^{10}$ LEW-E did not suppress humoral immune responsiveness aspecifically (Fig. V.1.).

\section{The presence or absence of antigen-antibody complexes}

Since antigen-antibody complexes are capable of suppressing immune responses specifically (35) and LEW-E opsonized with anti LEW-E antibody are most likely to constitute immune complexes possibly involved in our model the presence or absence of opsonized LEW-E in LEW-E unr. BN rats was assessed. In vivo opsonization of LEW-E was determined by comparing the sequestration of $1 \times 10^{10}$ $L E W-E$ and $B N-E$ in young or adult BN rats. Coating of allogeneic erythrocytes with antibody was expected to reduce the half-life of these cells (78). Hence, one and three months old BN rats were infused with either $1 \times 10^{10}{ }^{51} \mathrm{Cr}$-labelled allogeneic LEW-E or syngeneic BN-E. Each group comprised 5 or 6 BN rats. Radioactivity (in $\mathrm{cpm}$ ) per $\mathrm{ml}$ of blood as calculated from $0.5 \mathrm{ml}$ blood samples obtained one day after infusion of the labeled erythrocytes was taken to represent a state of equilibration of the infused erythrocytes in the recipients and was taken as $100 \%$. Radioactivity was measured in blood samples obtained every 4 th day thereafter and

FiG. V.1. Specificity of unresponsiveness in LEW-E unr. BN rats.

$B N$ rats one month of age were made unresponsive to LEW-E by one infusion of $1 \times 10^{\prime \prime}$ LEW-E. Two weeks later these LEW.E unr. rats and unmodified, age-matched controls were infused with three bi-weekly infusions of either $1 \times 10^{8} \mathrm{LEW}-\mathrm{E}$ or $\mathrm{I} \times 10^{6} \mathrm{SRBC}(1)$. Closed symbols, LEW-E unr. BN rats; open symbols, unmodified BN controls. $\square, \square$, anti-SRBC hemagglutinins $(\lg M+\operatorname{Ig} G) ; 0,0$, anti $\mathrm{LEW}-\mathrm{E}$ IgM hemagglutinins; $\triangle A$, anti LEW $\mathrm{E}$ IgG hemagglutinins. Vertical bars represent SEM. 
was corrected for body weight increase of the recipient and isotope decay. From the corrected radioactivity the percentage of infused erythrocytes present in the host was calculated.

Three month old $\mathrm{BN}$ rats eliminated $1 \times 10^{10}$ LEW-E more rapidly than $1 \times 10^{10}$ syngeneic BN-E (Fig. V.2A); the accelerated removal of $U_{\mathrm{N}} \mathrm{E}-\mathrm{E}$ from the circulation of these BN hosts coincided with the appearance of $\operatorname{IgM}$ hemagglutinins in the serum of these rats. In contrast, $\mathrm{LEW}-\mathrm{E}$ and $\mathrm{BN}-\mathrm{E}$ disappeared at the same rate from the circulation of one month old BN rats (Fig. V. 2B). Thus, allogeneic LEW-E infused in a dose of $1 \times 10^{10}$ into one month old BN rats had a half-life identical to that of syngeneic BN-E indicating that LIW-E were not opsonized.

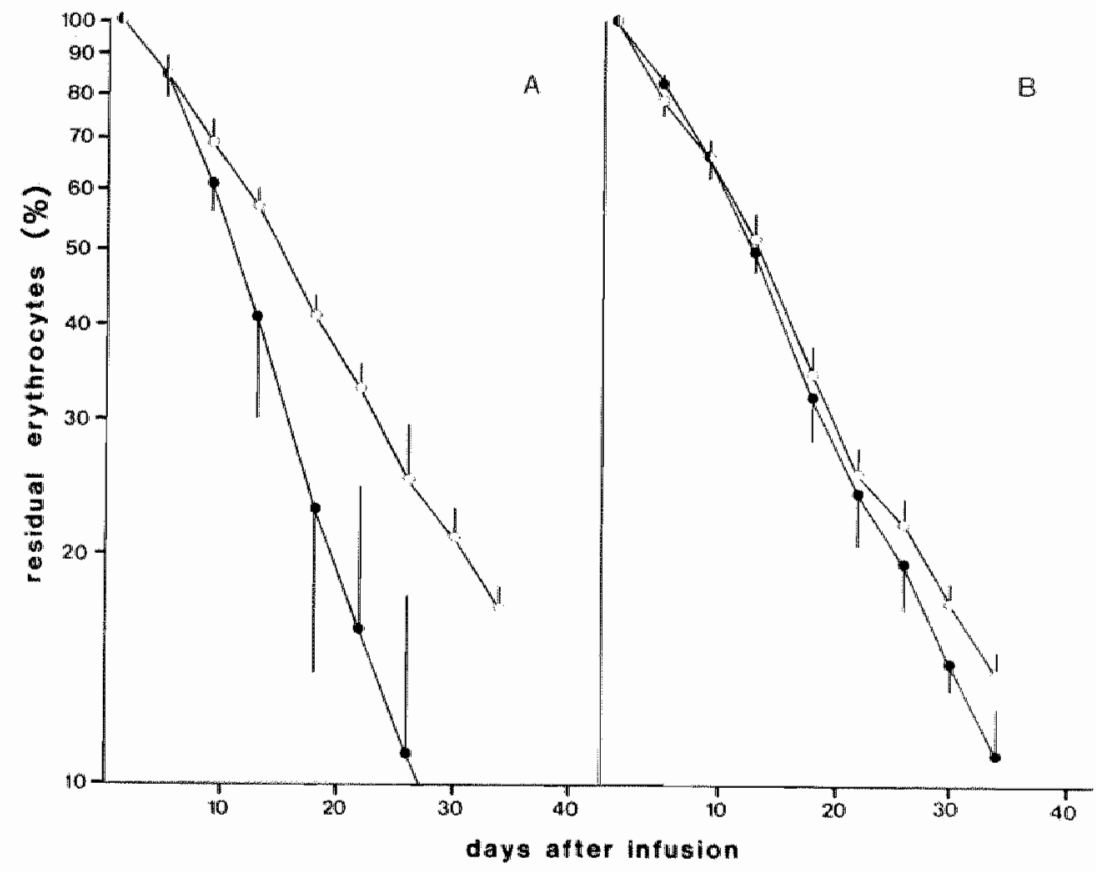

FiG. V.2. Disappearance of $1 \times 10^{10} \mathrm{LEW}-\mathrm{E}$ from the circulation of one month old and three months old BN rats.

Three months old (panel A) and one month old (panel B) BN rats were infused with $1 \times 10^{11}$ s: $\mathrm{Cr}$-labeled syngeneic or allogeneic erythrocytes. The percentage residual erythrocytes was calculated from blood samples taken at 4-day intervals. O, BN-E; - LEW-E. Vertical bars represent SD. 


\section{The presence or absence of humoral suppressor factors}

Blocking factors, presumably tolerogenic degradation products of antigen (7) or anti-idiotypic antibody (28) can mask a humoral immune response or give rise to immunological unresponsiveness. If involved in the maintainance of unresponsiveness to LEW-E in BN rats these factors may be expected to be present in the serum of these recipients. Therefore, 6 three months old $\mathrm{BN}$ rats were infused with $1.0 \mathrm{ml}$ of serum from LEW-E unr. BN rats 4 days and one day prior to an i.p. injection of $1 \times 10^{7} 2500$ rad X-irradiated LEW spleen cells. Infusions with serum from LEW-E unr, BN rats were given three times at one-week intervals. Each infusion was. followed one day later by an injection of $1 \times 10^{7} \mathrm{X}$-irradiated LEW spleen cells. Controls consisted of groups of 6 BN rats each which were either infused with serum from normal $\mathrm{BN}$ rats or received X-irradiated splenocytes only.

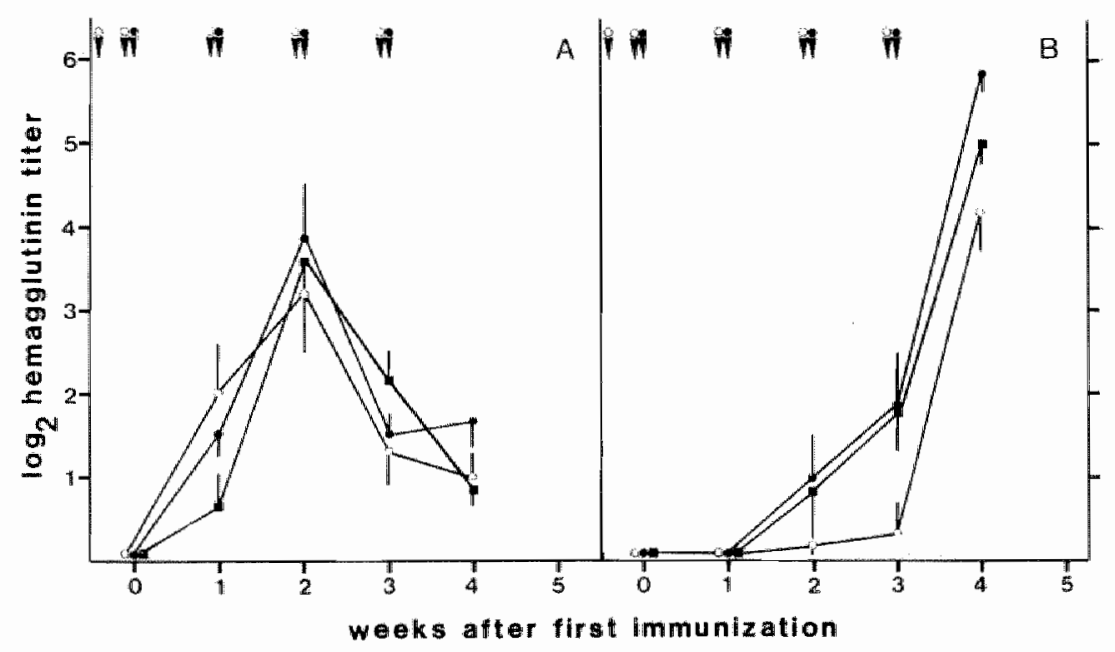

FiG. V.3. Effect of transfer of serum from $L E W-E$ unr. $B N$ rats on anti $L E W$ hemagghutinin production by unmodified $B N$ rats.

Groups of 6 adult BN rats each received $1.0 \mathrm{ml}$ infusions of serum from LEW-E unr or unmodified BN rats (i) or were left untreated. Rats were immunized with $1 \times 10^{*} 2500 \mathrm{rad}$ X-irradiated LEW splenocytes i.p. (1). Panel A, anti LEW IgM hemagglutinins; panel B, anti LEW IgG hemagglutinins. $O$, unmodified controls; - , recipients of serum from unmodified $B N$ donors; $\square$, recipients of serum from $\mathbb{L E W}-\mathrm{E}$ unr. $\mathrm{BN}$ donors. Vertical bars represent SEM. 
Infusion of BN serum from either source prior to immunization with LEW spleen cells did not alter anti LEW hemagglutinin responses in BN rats (Fig. V.3). Therefore, humoral factors as described above were not likely to play a major role in the maintainance of unresponsiveness to LEW-E-associated antigens in LEW-E unr. BN rats.

\section{Nature of the unresponsiveness}

The first set of experiments was designed to decide whether unresponsiveness of $B N$ rats to LEW-E was due to active suppression of immune reactivity or alternatively was due to non-reactivity or deletion of antigen-reactive $\mathrm{T}$ or $\mathrm{B}$ lymphocytes. If non-reactivity or deletion of antigen-reactive cells caused the unresponsiveness than transfer of normal $\mathrm{BN} B$ and $T$ lymphocytes might restore immune responsiveness to LEW Class I alloantigens. Therefore, LEW-E unr. BN rats were given $5 \times 10^{7}$ nylon wool non-adherent $\left(\mathrm{T}^{\prime}\right)$ or $5 \times 10^{7}$ nylon wool adherent $\left({ }^{\prime} \mathrm{B}^{\prime}\right)$ splenocytes from normal $\mathrm{BN}$ recipients i.v. and were next immunized i.p. with $1 \times 10^{7}$ $2500 \mathrm{rad} X$-irradiated LEW spleen cells. The finding that transfer of normal BN $T$ and $B$ lymphocytes failed to restore immune responsiveness (Table V.1) suggested that active suppression rather than inactivation or elimination of antigen-reactive $T$ or $B$ lymphocytes was responsible for the unresponsiveness to LEW-E-associated antigens in LEW-E unr. BN rats. Suggestive evidence that suppression of antigen-reactive $B$ cells caused the unresponsiveness to LEW Class I antigens in LEW-E unr. BN rats derived from the finding that LEW skin allografts grafted onto LEW-E unr. BN rats elicited hemagglutinating alloantibodies in 8 out of 8 instances. Also repeated i.p. injections of $I \times 10^{7} 2500 \mathrm{rad} X$-irradiated splenocytes into LEW-E unr. BN rats 'broke' the unresponsiveness to LEW-E-associated antigens in one out of three animals (Table V.1).

The second set of experiments was designed to elucidate the mechanism of suppression by means of adoptive transfer experiments. In these experiments the capacity of spleen cells obtained from LEW-E unr. BN rats to suppress humoral responses to LEW-Eassociated antigens in both unmodified and $\mathrm{X}$-irradiated $\mathrm{BN}$ rats reconstituted with $5 \times 10^{7}$ syngeneic bone marrow cells $(X, R$ $\mathrm{BN}$ rats) was determined. 


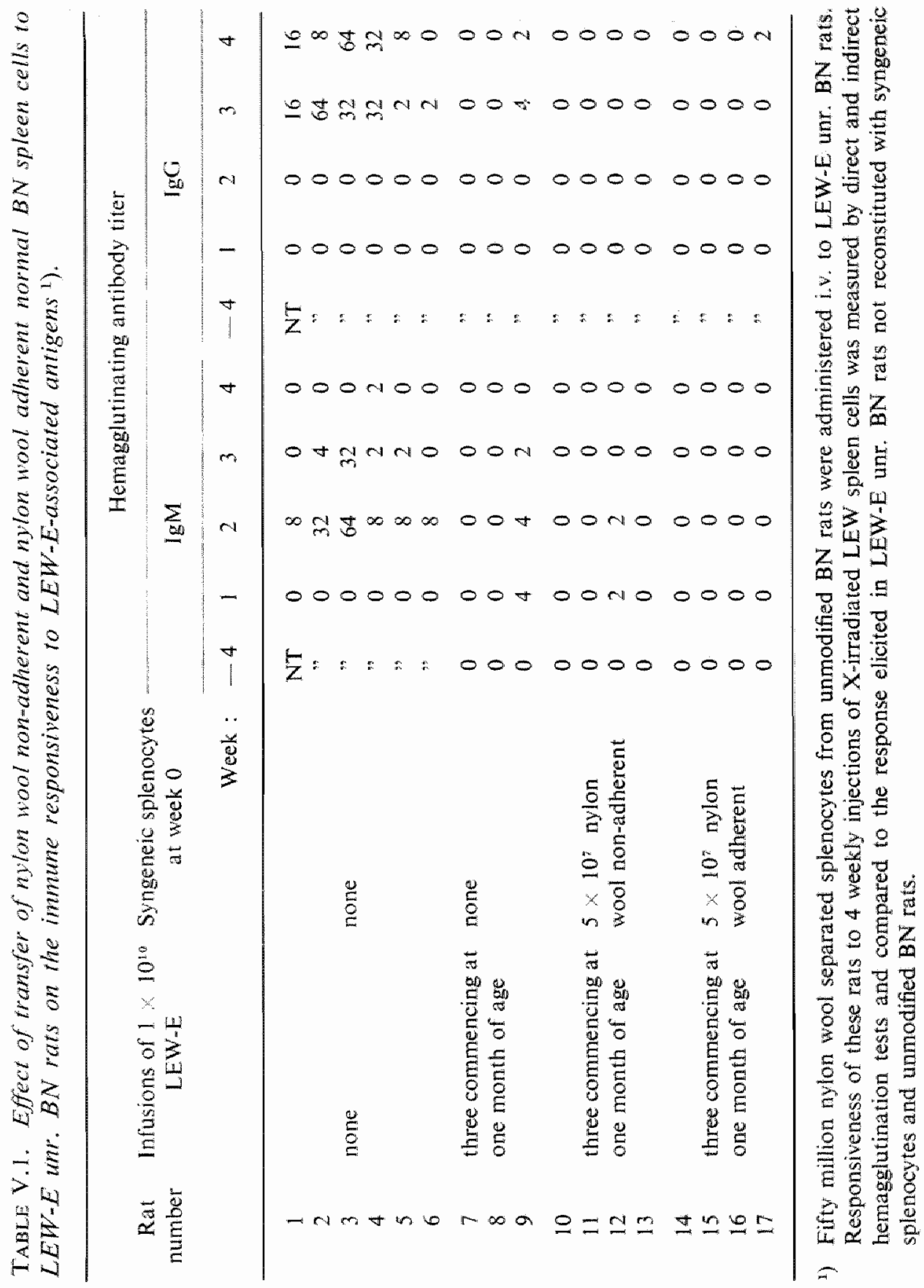


In the first experiment, three month old BN rats were $\mathrm{X}$-irradiated with $850 \mathrm{rad}$ and reconstituted 6 hours later with $5 \times 10^{7} \mathrm{BN}$ bone marrow cells together with splenocytes obtained from LEW-E unr. BN rats (splenocytes B, see below) or together with splenocytes from unmodified BN donors (splenocytes A). Twenty-four hours after X-irradiation $X, R$ BN rats were given $1 \times 10^{7} 2500 \mathrm{rad}$ $X$-irradiated LEW spleen cells i.p.; these immunizations were repeated weekly for 3 weeks. Blood samples were obtained before immunizations and one week after the last immunization and anti LEW IgM and IgG hemagglutinins measured. The protocol can be summarized as follows :

BN recipients three Infusion of $5 \times 10^{7}$ syn- Injection of $1 \times 10^{*}$ months of age, $850 \rightarrow$ geneic bone marrow cells $\rightarrow 2500$ rad $X$-irradiated rad $X$-irradiated whrs and spleen cells from un-2thr. LEW spleen cells i.p. modified BN rats (spleno- (repeated weekly, $x 3$ ) cytes A, see below) or from LEW-E unr. BN rats (splenocytes $B$, see below)

The groups examined for anti LEW-E antibody production were constituted as shown below:

Group ${ }^{1} \quad$ No. or recipients Syngeneic spleen cells transferred

\begin{tabular}{llc}
\hline 1 & 5 & $\left.1 \times 10^{8} \mathrm{~A}\right)$ \\
2 & 2 & $2 \times 10^{8} \mathrm{~A}$ \\
3 & 4 & $\left.1 \times 10^{8} \mathrm{~B}\right)$ \\
4 & 2 & $2 \times 10^{8} \mathrm{~B}$ \\
5 & 5 & $1 \times 10^{8} \mathrm{~A}+1 \times 10^{8} \mathrm{~B}$ \\
6 & 6 & none \\
\hline
\end{tabular}

1) Groups 1-5: X, R BN recipients; group 6: Unmodified BN recipients

2) A : Spleen cells from unmodified BN rats.

a) B : Spleen cells from LEW-E unr. BN rats.

This experiment showed that the number of splenocytes adoptively transferred did not influence the hemagglutinating antibody response to $1 \times 10^{7} 2500 \mathrm{rad} \mathrm{X}$-irradiated LEW splenocytes since 
the hemagglutinin titers of $\mathrm{BN}$ recipients of $1 \times 10^{8}$ normal syngeneic splenocytes did not differ from those receiving $2 \times 10^{8}$ syngeneic splenocytes (groups 1 and 2 ); also the hemagglutinin titers of $\mathrm{X}, \mathrm{R}$ BN rats receiving $1 \times 10^{8}$ and $2 \times 10^{8}$ splenocytes from LEW-E unr. BN rats (groups 3 and 4 ) did not differ. Therefore, the results of groups 1 and 2 on the one hand and groups 3 and 4 on the other hand have been taken together in presenting the results (Fig. V.4). Results show that compared to unmodified BN

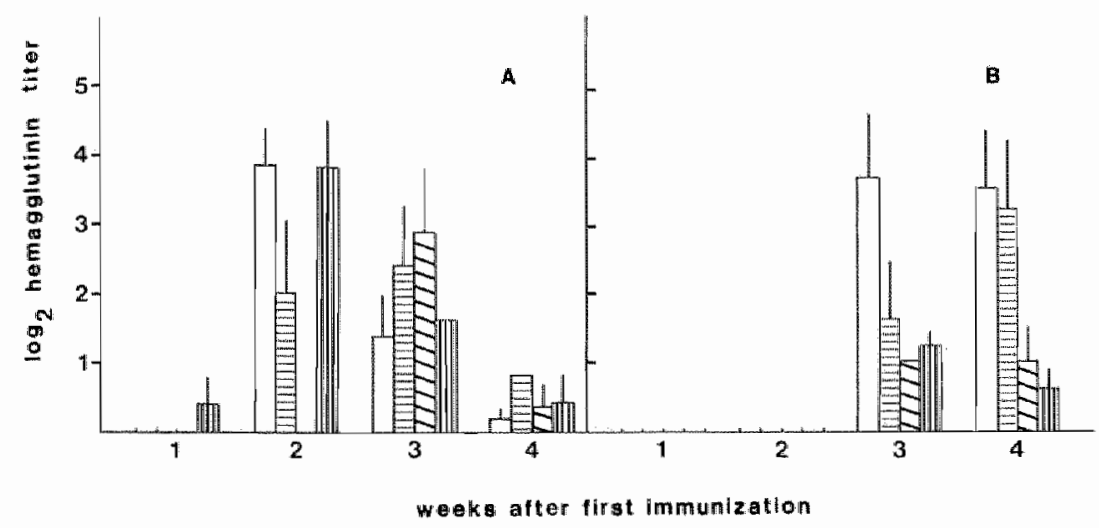

FIG. V.4. Effect of adoptive transfer of spleen cells from $L E W-E$ unr. $B N$ rats on anti $L E W$ hemagg/utinin production by $X, R$ $B N$ rats.

$X, R$ BN rats received $1-2 \times 10^{8}$ spleen cells either from unmodified $B N$ donors, from LEW-E unr. BN donors, or from both types of donors. Anti LEW-E hemagglutinins were elicited by 4 weekly i.p. immunizations with $1 \times 10^{*} 2500 \mathrm{rad} X$-irradiated LEW spleen cells. Panel A, anti LEW $\| \mathrm{gM}$ hemagglutinins; panel B, anti LEW IgG hemagglutinins. Open bars, unmodified BN recipients; horizontally shaded bars, recipients of splenocytes from unmodified BN donors; obliquely shaded bars, recipients of splenocytes from LEW-E unr. BN donors; vertically shaded bars, recipients of equal doses of splenocytes from unmodified and LEW-E unr. BN donors. Vertical lines indicate SEM.

rats (group 6) in $\mathrm{X}, \mathrm{R}$ BN rats given normal $\mathrm{BN}$ splenocytes (groups 1 and 2) anti LEW IgG hemagglutinins appeared delayed after i.p. immunization with X-irradiated LEw splenocytes. Both groups of $\mathrm{BN}$ rats showed comparable IgG hemagglutinin titers at one week after the 4 th immunization. It is clear that one week after 
the 4th immunization with $\mathrm{X}$-irradiated LEW splenocytes $\mathrm{X}, \mathrm{R}$ BN rats given spleen cells from LEW-E unr. BN rats (groups 3 and 4) showed a clearcut depression of IgG hemagglutinins when compared to controls (groups 1 and 2$)(P=0.13)$. $\mathrm{X}, \mathrm{R}$ BN rats given a mixture of spleen cells from LEW-E unr. BN rats and normal $B N$ rats (group 5) also showed a marked decrease in IgG hemagglutinins after i.p. immunization with $\mathrm{X}$-irradiated LEW splenocytes when compared to controls (groups I and 2) $(P=0.036)$. IgM hemagglutinin responses on the other hand were not clearly influenced, although this response was delayed for one week in $X, R$ BN recipients of splenocytes from LEW-E unr. donors (groups 3 and 4) compared to all other groups. Taken together, these findings indicate that spleen cells of LEW-E unr. BN rats contain a cell population(s) that suppresses anti LEW-E IgG antibody production in adoptive transfer experiments.

In the next experiment we tried to ascertain if the suppressive effect on anti LEW-E IgG antibody responses as noticed in the first experiment was mediated by $\mathrm{T}$ lymphocytes. To avoid an effect of X-irradiation on the immune response elicited after spleen cell transfer unmodified BN rats were used as recipients of spleen cells from LEW-E unr. and unmodified $\mathrm{BN}$ rats. $\mathrm{T}$ lymphocytes were isolated from spleen cell suspensions by passage over nylon wool columns; $6 \mathrm{BN}$ rats received $5 \times 10^{7}$ splenic T cells from LEW-E unr. BN donors and three $\mathrm{BN}$ rats received $5 \times 10^{7}$ splenic $\mathrm{T}$ lymphocytes from unmodified $B N$ rats age-matched with the LEW-E unr. BN donors. Anti LEW hemagglutinin responses were elicited by three infusions of $1 \times 10^{9}$ LEW-E administered at two-week intervals. As shown in Fig. V.5 the findings from the first experiment were essentially reproduced in this model of adoptive transfer. Primary anti LEW IgM hemagglutinin responses were identical in $B \mathrm{~N}$ recipients of $\mathrm{T}$ lymphocytes obtained from unmodified and LEW-E Unr. BN rats. At one and two weeks after the third immunization anti LEw-E $\operatorname{lgG}$ - and secondary $\operatorname{lgM}$ antibody responses of $B N$ recipients of $T$ cells from $L E W-E$ unr. BN donors were significantly suppressed compared to the responses in BN rats supplemented with $\mathrm{T}$ cells from control donors (IgM : $P=0.012$ and $P=0.012$ respectively, $\operatorname{lgG}: P=0.012$ and $P=0.024$ respectively). In order to determine the specificity of the suppression of the hemagglutinin response to LEW splenocytes by adoptive transfer 
of splenic $T$ cells from LEW-E unr. rats, BN rats were given splenic T lymphocytes obtained from unmodified and LEW-E unr. BN donors and next challenged with $1 \times 10^{9}$ SRBC instead of LEW-E. The kinetics of the anti SRBC hemagglutinating antibody responses were identical in recipients of splenocytes from either type of donors. Thus, adoptive transfer of splenic $T$ lymphocytes from

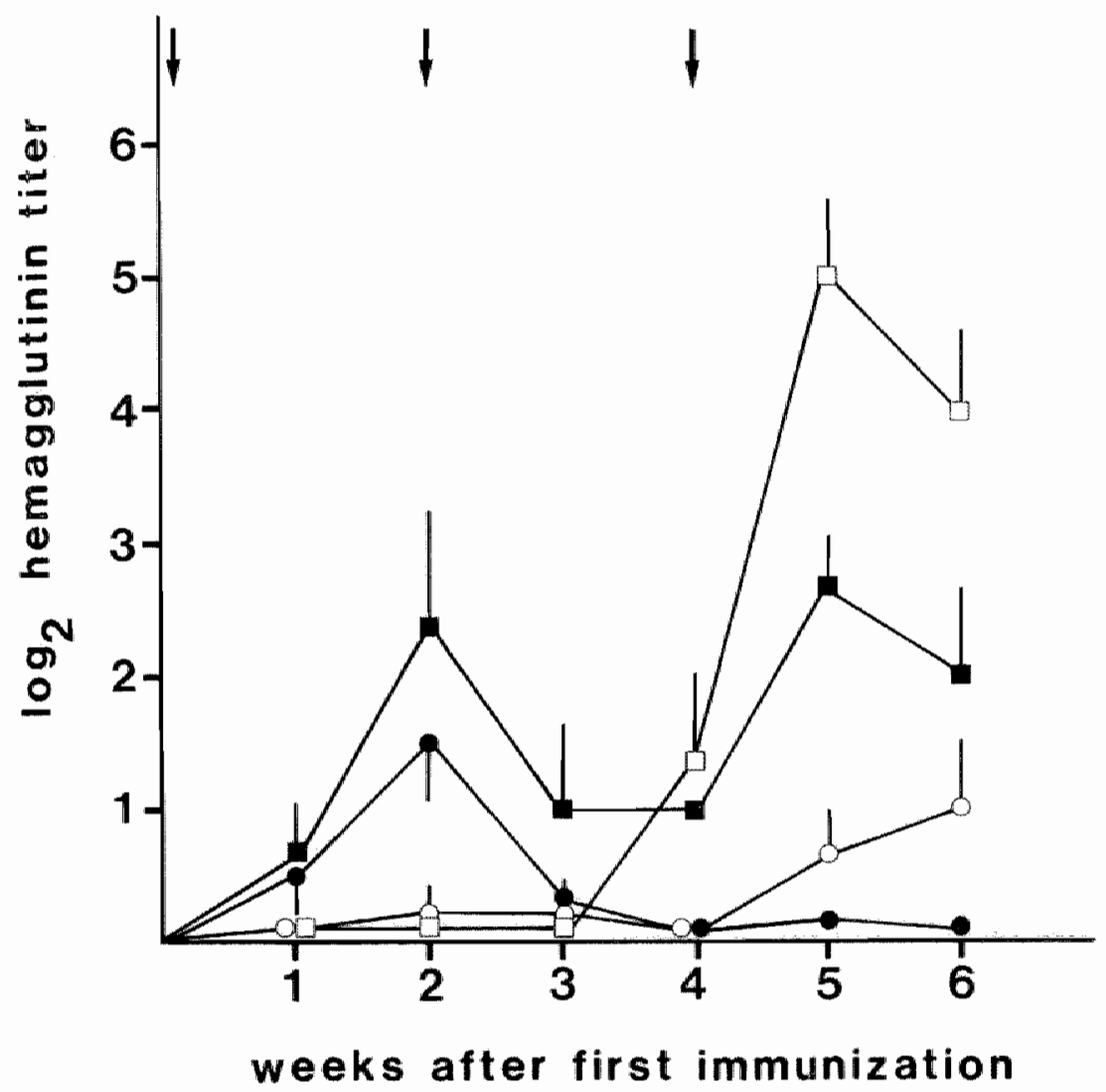

Fig. V.5. Effect of adoptive transfer of splenic $T$ cells from $L E W-E$ unr. BN rats on anti LEW hemagglutinin production by $B N$ recipients.

Six BN rats received $5 \times 10^{7}$ splenic T lymphocy tes from LEW-E unr. BN rats (circles) and three $\mathrm{BN}$ rats received $5 \times 10^{7}$ splenic $\mathrm{T}$ lymphocytes from unmodified BN donors (squares). Anti LEW hernagglutinins were elicited by three biweekly infusions of $1 \times 10^{g}$ LEW-E $(\downarrow)$. $\varpi, 0$, IgG hemagglutinins. Vertical bars represent SEM. 
LEW-E unr. BN rats into syngeneic recipients suppressed anti LEW-E antibody responses in these rats but did not influence responsiveness to SRBC.

\section{Discussion}

The results obtained in this study indicate that unresponsiveness to LEW-E-associated antigens induced by infusion of $1 \times 10^{10} \mathrm{LEW}-\mathrm{E}$ in one month old $\mathrm{BN}$ rats was 1) antigen specific, 2) not likely to be due to clonal deletion or -abortion 3) at least controlled in part by suppressor $\mathrm{T}$ lymphocytes and 4) possibly also caused by (reversible) inactivation of antigen-specific B cells ( $/ 0)$.

Involvement of suppressor T lymphocytes was suggested by the last experiment in which unresponsiveness to LEW-E was adoptively transferred from LEW-E unr. BN rats to unmodified BN recipients by nylon wool non-adherent spleen cells. However, this experiment did not unequivocally demonstrate that suppressor $T$ cells mediated unresponsiveness to LEW-E in $\mathrm{BN}$ rats in vivo for two reasons. First, nylon wool non-adherent spleen cells contain about $5 \%$ B lymphocytes (22, and Chapter III, Section 7.2.1) and second, the macrophages from the spleen were retained on the nylon wool collumns; macrophages can mediate immunosuppression in vitro $(8,36,47)$. It is unlikely however that $\mathrm{B}$ lymphocytes or macrophages caused unresponsiveness to LEW-E in BN rats. B lymphocytes are thought to act in an immunosuppressive fashion by means of secreting antigen-specific antibody $(33,40)$; since hemagglutinin titers in sera of $\mathrm{BN}$ recipients of nylon wool non-adherent lymphocytes did not exceed the titers of sera of controls, depression of hemagglutinin responses in the former recipients is unlikely to be mediated by antibody produced by adoptively transferred B lymphocytes. Also no such antibody was demonstrable in adoptive transfer experiments where $X, R$ rats were reconstituted with whole spleen cell suspensions from LEW-E unr. BN donors. Next, cells of the mononuclear phagocyte series have been shown to adhere to nylon wool as well (16). Macrophages have been shown to act as suppressor cells in severall in vitro systems, but their action always resulted in aspecific suppression of immune responsiveness $(8,36,47)$. Because aspecific suppression of humoral responsiveness was not detected in LEW-E unr. BN rats, splenic macrophages 
from LEW-E unr. BN rats were not likely to have exerted an aspecific immunosuppressive effect.

In both adoptive transfer experiments IgG, but not IgM hemagglutinin responses to $X$-irradiated LEW splenocytes were suppressed by spleen cells from LEW-E unr. BN rats. Since IgG, but not IgM antibody production to $\mathrm{T}$ cell-dependent antigens - including transplantation antigens - depends on the activation of helper $T$ cells ( 30 ) our observations may in part be explained by assuming that suppressor $\mathrm{T}$ cells blocked the induction of helper $\mathrm{T}$ cells. It is remarkable that $X, R$ BN recipients of spleen cells from LEW-E unr. BN rats were able to produce anti LEW-E IgG antibody. Possible explanations for this finding include antibody formation by injected bone-marrow cells 'homed to the recipients bone-marrow bringing them out of reach of suppressor cells (37); "dilution' of B and T cells in the lymphoid organs of the recipient making a number of B cellls inaccessible for suppressor $T$ cell factors (42) and breaking' of suppression by helper $T$ cells differentiated from the syngeneic bone-marrow inoculum.

On the other hand, the B cell population of LEW-E unr. BN rats with specificity for LEW-E-associated antigens might also be affected directly as suggested by two observations. First, in contrast to the results obtained by adoptive transfer experiments, primary $\operatorname{IgM}$ responses to LEW-E were rarely observed in recipients of $1 \times 10^{10} \mathrm{LEW}-\mathrm{E} / 100 \mathrm{~g}$ body weight; and second, spleen cells from LEW-E unr. BN rats transferred to $X, R$ BN rats caused these recipients to respond in a delayed fashion with $\operatorname{IgM}$ hemagglutinins to immunizations with LEW splenocytes. The delayed anti LEW-E IgM antibody responses may either reflect reversable B cell tolerization $(10,12)$ or alternatively activation of $\mathrm{B}$ cells differentiated from the bone-marrow inoculum used to reconstitute $\mathrm{X}$-irradiated BN rats.

The fact that transfer of nylon wool adherent spleen cells from unmodified BN rats to LEW-E unr. BN recipients did generally not restore anti LEW-E IgM antibody responses to X-irradiated LEW splenocytes may be due to inactivation of $B$ cells in this population by LEW-E still present in the host at the time of transfer (Cf. Fig. V.2B). Although these observations leave the possibility that $B$ cell inactivation existed in LEw-E unr. BN rats this was 
excluded to be of an irreversible type (clonal deletion of -abortion) because LEW skin grafts transplanted to LEW-E unr. BN rats elicited anti LEW hemagglutinin responses.

\section{Summary}

Experiments described in this Chapter were performed to elucidate which of the many known immunoregulatory circuits were involved in the maintainance of unresponsiveness to LEW-E-associated antigens in LEW-E unr. BN rats. Suppression was shown to be antigen-specific and to be transferable by splenic $T$ lymphocytes, but not with serum from LEW-E unr. BN rats to unmodified syngeneic recipients.

Adoptive transfer of spleen cells from LEW-E unr. BN rats to $X, R$ $B N$ rats or of splenic $T$ cells from $L E W-E$ unr. BN rats to unmodified BN recipients suppressed anti LEW-E IgG and secondary IgM responses but did not affect primary IgM hemagglutinin responses. These observations suggested suppressor $\mathrm{T}$ cells to interfere with the activation of helper $T$ cells in LEW-E unr. BN rats. On the other hand, primary $\operatorname{IgM}$ responses were only rarely observed in $\mathrm{BN}$ rats infused with $1 \times 10^{10}$ LEW-E/100 g body weight and appeared delayed in $X, R$ BN recipients of spleen cells from LEW-E unr. donors. Thus, $B$ cells residing in LEW-E unr. BN rats and having specificity for LEW-E-associated antigens may be inactivated as well, albeit in a reversible fashion for LEW skin grafted onto LEW-E unr. BN rats invariably "broke" the unresponsiveness. 


\section{References}

1 Aguet, M., Andersson, L. C., Andersson, R., Wight, E., Binz, H., and Wigzel., $H$.: Induction of specific immune unresponsiveness with purified mixed leukocyte culture-activated $T$ lymphoblasts as immunogens. J. Exp. Med. $147:$ 50, 1978.

2 Basten, A., Mlller, J. F. A. P., Loblay, R., Johnson, P., Gamble, J., Chia, E, Pritchard-Briscoe, H., Callard, R., and McKenzie, I. F. C. : T cell-dependent suppression of antibody production. I. Characteristics of suppressor T cells following tolerance induction. Eur. $J$. Immunol. 8: 360, 1978.

3 Bullingham, R. E., Brent, L., and Medawar, P. B. : Quantilative studies on tissue transplantation immunity. III. Actively aquired tolerance. Philos Trans. Roy. Soc. London 239: 357, 1956.

4 Brideau, R. J., Carter, P. B., MCMaster, W. R., Mason, D. W., and Willdams, A. F. : Two subsets of rat $\mathrm{T}$ lymphocytes defined with monoclonal antibodies. Eur. J. Immunol. 10:609, 1980.

5 Burnet, F. M. : The Clonal Selection Theory of Aquired Immunity, Cambridge University Press, Cambridge, 1959.

6 CAntor, H., Shen, F. W., and Boyse, E. A. : Separation of helper T cells from suppressor $T$ cells expressing different Ly components. II. Activation by antigen : after immunization, antigen-specific suppressor and helper activities are mediated by distinct $\mathrm{T}$ cell subclasses. $J$. Exp. Med. 143: $\Vdash 39 \rrbracket, 1976$.

7 Chutna, J., Hasek, M., Holan, V., and Sladecek, M.: Induction ol specific transplantation tolerance with blood serum in newborn and adult rats. Eur. J. Immunol. $7: 298,1977$.

8 Corvallan, J. R. F., and Howard, J. C. : Primary in vitro antibody formation in the rat: partial chatacterization and properties of an inhibitor cell present in normal spleen. Eur. J. Immunol. 8: 331, 1978.

9 DANCHN, A. : The specification of the immune response: a general selective model. Mol. Immunol. 16: 515, 1979.

10 Desarmard, C. : Reversal of B-cell immunization or tolerization by specific enzymatic degradation of the antigen. Ann. Immunol. $129 \mathrm{C}$ : $871,1978$.

18 DesaYmard, C., and WaLdman, H.: Evidence for the inactivation of precursor $\mathrm{B}$ cells in high dose unresponsiveness. Narure 264:780, 1976.

12 Diener, E, and FeldmanN, M.: Mechanisms at cellular level during induction of high zone tolerance in vitro. Cell. Immunol. $5: 130,1972$.

13 Feldmann, M., and Diener, E.: The effect of antibody fragments. J. Immunol. $108: 93,1972$. 
14. Fernandez, $C$, and Möller, $G$.: Specific antibodies are responsible for the low dose suppression of the immune response to thymusindependent antigens. Scand. J. Immanol. $7: 331,1978$.

15 Gershon, R. K., and Kondo, K.: Infectious immunological tolerance. Inimunology $21: 903,1971$.

16 HANDwercer, B. S., and Schwartz, R. H. : Separation of murine lymphoid cells using nylon wool columns. Recovery of the B cell-enriched population. Transplantarion $18: 544,1974$.

17 Herzenberg, L. A.; BLACK, S. J., and Herzenberg, L. A. : Regulatory circuits and antibody responses. Eur. J. Immwn. 10: 1, 1980.

18 Heslop, B. F., and Heslop, H. E. : Allogeneic red blood cells fail to induce hatemagglutinating antibodies or cellular alloimmunity in rats and are immunosuppressive. Transplantation 28:144, 1979.

19 Hutchinson, I. V. : Antigen-reactive cell opsonization (ARCO) and its role in antibody-mediated immune suppression. Immonol. Rev. 49: 167. 1980 .

20 Hutchinson, I. V., and ZoLA, H. : Antigen-reactive cell opsonization: A mechanism of antibody-mediated immune suppression. Cell. Immumol. $36: 171,1978$.

21 JERNE, N. K. : The immune system : a web of V-domains. Harvey Lect. 70 : $113,1975$.

22 Julius, M. H., Simpson, E., and Herzeniberg, L. A. : A rapid method for the isolation of functional thymus-derived murine lymphocytes. Eur. J. Immumol. 3: 645, 1973.

23 KaAtrari, S., Scibienski, R. J., and Benjamini, E. : The immuno-regulatory role of antigen-antibody complexes. I. Assessment of B and T-cell responses. Immunology $40: 9,1980$.

24 KEOWN, P. A., and DESCAMPS, B. : Improved renal allograft survival after blood transfusion: A nonspecific, erythrocyte-mediated immunoregulatory process? Lancet I : 20, 1979.

25 KöLSCH, E., STumpF, R., and WERER, Gi. : Low zone tolerance and suppressor T cells. Transplant. Rew. 26:56, 1975.

26 Letvin, N. L., Fox, I. J.; Greene, M. I., Benacerraf, B., and Germain R. N. : Immunologic effects of whole body ultraviolet (UV) irradiation. II. Defect in splenic actherent cell antigen presentation for stimulation of $T$ cell proliferation. $J$. Immunol. $125: 1402,1980$.

27 MATtingLy, J. A., and Waksman, B. H. : Immunologic suppression after oral administration of antigen. 1 . Specific suppressor cells formed in rat Peyer's patches after oral administration of sheep erythrocytes and their systemic migration. J. Immunol. 121:1878, 1978.

28 MCKearn, T. J., Stuart, F. P., and Fitch, F. W. : Anti-idiotypic antibody 
in rat transplantation immunity. I. Production of anti-idiotypic antibody in animals repeatedly immunized with alloantigens. $J$. Immonol. II3: 1876,1974 .

29 Metcalf, E. S., Schrater, A. F., and Klinman, N. R. : Murine models of tolerance inductions in developing and mature B cells. Immonol. Rev. 43:143, 1979.

30 Mrtohell, G. F. : In The Lymphocyte: Structure and Funcrion. J. J. Marchalonis (ed.), p. 232, Dekker, New York, 1975.

31 Moretta, L., Webr, S. R., Grossi, C. E., Lidyard, P. M., and Cooper, M. D. : Functional analysis of two human T-cell subpopulations: help and suppression of $B$ cell responses by $T$ cells bearing receptors for IgM or IgG. J. Exp. Med. 146:184, 1979.

32 Morgan, E. L., and Tempelis, C. H. : The requirement for the Fo portion of antibody in antigen-antibody complex-mediated immuno-suppression. J. Immunol. 120: 1669, 1978.

33 Morris, A., and Möller, $G$. : Regulation of cellular antibody synthesis. Effect of adoptively transferred antibody-producing spleen cells on cellular antibody synthesis. J. Immunol. 101 : 439, 1968.

34 Nossal, G. J. V., Pike, B. L., Teak, J. M., Layton, J. E., Kay, T. W., and BATTYE, F. L. : Cell fractionation methods and the target cells for clonal abortion of B lymphocytes. Immunol. Rev. 43: 185, 1979.

35 Obermarnschend, J., and Kölsch, E. : Direct blockade of antigen-reactive B lymphocytes by immune complexes. An 'off' signal for precursors of IgM producing cells provided by the linkage of antigen and $\mathrm{Fc}$ receptors. Immunology 35: 151, 1978.

36 RAFF, H. Y., and HinRICHs, D. J.: Suppressor cell influence in selected strains of inbred rats. III. Evidence for non-specific suppression by a lymphocyte macrophage cooperation. Cell. Immunol. 29: 118, 1977.

37 RoziNG, J., Brows, N. H. C., and BENNER, R. : B-lymphocyte differentiation in lethally irradiated and reconstituted mice. 111. The influence of splenectomy on the recovery of the B-cell population. Cell. Immunal $3 \mathrm{I}$ : $340,1977$.

38 SAbet, T., Newlin, C., and Friedman, H. : Effects of RES blockade' on antibody-formation. I. Suppressed cellular and humoral haemolysin responses in mice injected with carbon particles. Immanology 16: $433,1969$.

39 SECOND international workshop on alloantigenic systems in the rat: combined report on reference testing of anti-T-lymphocyte alloantisera. Transplantant. Proc. 11: 1648, 1979.

40 Stockinger, B., Botzenhardi, U., and Lemmel. E.-M. : On the feedback regulation of humoral immune response. $\mathrm{C}$. Exidence for 'B suppressor cells'. Immunology $36: 87,1979$. 
41 SY, M.-S., BaCh, B. A., Dohi, Y., Nisonoff, A., Benacerraf, B., and GReENE, M. I. : Antigen and receptor-driven regulatory mechanisms. I. Induction of suppressor T cells with anti-idiotypic antibodies. J. Exp. Med. $150: 121.6,1979$.

42 TADA, T., and OKumura, K.: The role of antigen-specific $T$ cell factors in the immune response. Adv. Immunol. $28: 1,1979$.

43 TADA, T., TANiguchi, $M$., and TAkemori, $T$. : Properties of primed suppressor T cells and their products. Transplant. Rev. 26:106, 1975.

44 WrWEs, J., PARKs, D. E., and WEIGLE, W. O. : Immunologic unresponsiveness after gastric administration of human $\gamma$-globulin : antigen requirements and cellular parameters. J. Immunol. $125: 1811,1980$.

45 WAYNE STREILEIN, J. : Neonatall tolerance: towards an immunogenetic definition of self. Immunol. Rev. $46: 125,1979$.

46 Weigle, W. O. : Cyclical production of antibody as a regulatory mechanism in the immune response. $A d v$. Immunol. $21: 87,1975$.

47 Weiss, A., and FITCH, F. W. : Suppression of the plaque-forming cell response by macrophages present in the normal rat spleen. $J$. Immunol. $120: 357,1978$. 


\section{THE EFFECT OF AN ESTABLISHED ANTI LEW-E $\| \mathrm{gM}$ ANTIBODY RESPONSE ON THE REJECTION OF LEW RENAL GRAFTS BY BN RATS}

\section{Introduction}

Transfusion of whole blood from third party donors prior to transplantation of a kidney in man is generally accepted to have a beneficial effect on the survival of the graft $(44,48)$. Transfusion of whole third party blood has also been demonstrated to enhance canine renal allograft survival (41). Prolongation of kidney allograft survival was achieved in immunosuppressed monkeys provided the blood transfusions were tissue-typed and matched with the kidney donor (15) and in rats if the transfused blood was of donor strain origin $(16,34)$. In dog, rat and man blood transfusions may sensitize the recipient unwantedly and cause hyperacute or accelerated ant body-mediated rejection of kidney grafts $(18,21,29,33)$. The effect of sensitization of a prospective kidney graft recipient by blood transfusions in terms of accelerated or delayed renal allograft rejection in man is difficult to predict at least for four reasons :

1. Transfusion of whole blood may elicit antibodies to Class I antigens (HLA-A and $B$ ), to Class II antigens (HLA-D(R)), and to monocyte-associated antigens all of which may be present on the surface of the kidney graft's endothelial cells $(26,36,59)$. There is no consensus on the association of antibody specifity and their capacity to enhance or reject a renal graft. Studies in rodents e.g. favoured antibodies to Class II antigens to be most effective in enhancing graft survival $(11,12,52)$ but antibodies to Class I antigens have been shown to be effective in that respect as well (13, 22,28 ). On the other hand, antibodies to Class II antigens have been reported to be associated with accelerated rejection of renal grafts in man $(19,53)$.

2. Preexisting antibodies to any given specificity or combination of specificities may cause rejection or enhancement depending on 
the antigen density on the (endothelial) target cells as well as on the immunoglobulin class in which these antibodies reside. These factors may determine the ability of the antibody bound to the graft to activate complement $(31,35)$ and their efficiency to mediate antibody-dependent cellular cytotoxicity $(24,30)$.

3. Transfusions of whole blood may not only modulate the HVG response by means of antibody but may also interfere with cellular mechanisms such as the induction of cytotoxic suppressor T cells $(48,57)$.

4. Immunosuppressive therapy is administered to recipients of human renal allografts.

The studies described in this Chapter and the next one were designed to examine the effect of recipient sensitization with donor Class I antigens in an animal model since HLA-A and B matching in man has been shown by several groups to be associated with prolonged cadaver graft survival in immunosuppressed recipients $(5,9,27,43,45)$. This finding suggested that an immune responseinclusive preexisting antibodies - to donor Class I antigens may injure renal allografts. In this study we took advantage of the observation that in the rat Class $\mathrm{I}$ antigens are expressed on the surface of both erythrocytes $(58)$ and endothelial cells $(7,47)$ and that $\mathrm{BN}$ rats manufacture antibodies to Class $I$ antigens after immunization with LEW-E (Chapter IV). The effect of an IgM antibody response to LEW-E on the rejection of LEW kidneys has been described separately from the effect of IgG antibodies since in contrast to $\operatorname{lgG}$ - rat $\operatorname{lgM}$ does not activate homologous complement $(8,49)$ and may be ineffective in mediating antibodydependent (K-) cell cytotoxicity $(23,5 I)$.

\section{Experimental protocol}

Anti LEW-E IgM antibody responses were elicited in three month old $\mathrm{BN}$ rats by one infusion of $1 \times 10^{8} \mathrm{LEW}-\mathrm{E}$ and hemagglutinin titers were determined from serum samples obtained just prior to transplantation. LEW kidneys were grafted to BN anti LEW-E IgM (IgM-BN) responders between 11 and 15 days after infusion of LEW-E. The immune response elicited by LEW kidneys in IgM-BN hosts was compared to that of LEW kidneys residing in unmodified BN 
recipients using graft function, HVG humoral and cellular immune responses and graft histology as parameters.

\section{Survival of $L E W$ renal grafts in IgM-BN hosts}

Compared to LEW kidneys transplantated into unmodified BN hosts an established BN anti LEW-E IgM antibody response did not influence the renal function of LEW renal grafts as judged by the serum urea concentration up to the 6 th day post-operatively (Fig. VI.1). At the 5th or 6th day after transplantation LEW renal grafts inserted into unmodified $\mathrm{BN}$ rats ceased to function as shown by an abrupt increase in the serum urea concentration of the host.

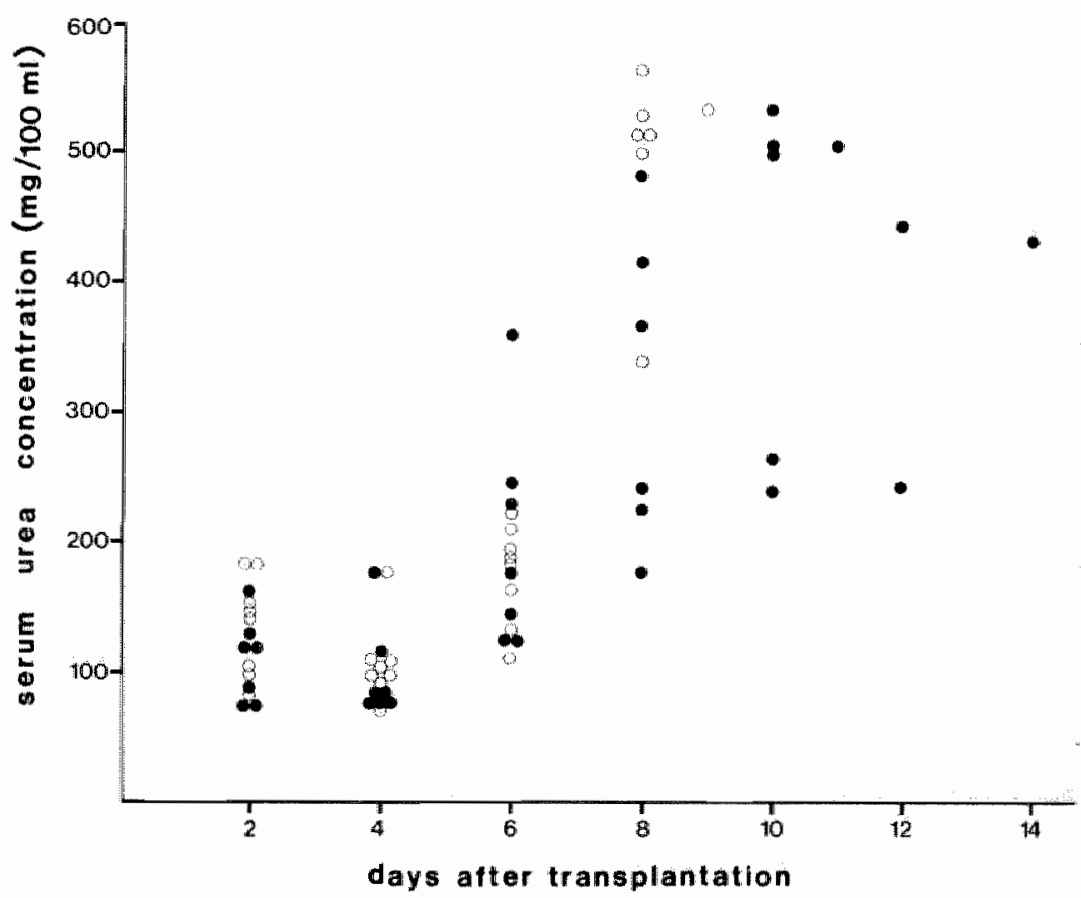

FIG. VI.1. Serum urea concentrations of unmodified and IgM-BN hosts of LEW kidneys.

- IgM-BN hosts of LEW kidneys; 0 , unmodified BN hosts of LEW kidneys. A serum urea concentration exceeding $400 \mathrm{mg} / 100 \mathrm{ml}$ was equated with rejection. 
On the 8th day after transplantation serum urea concentrations exceeded $400 \mathrm{mg} / 100 \mathrm{ml}$ in 7 out of 8 instances; one recipient had a serum urea concentration of $338 \mathrm{mg} / 100 \mathrm{ml}$. The serum urea concentration in $\mathrm{IgM}-\mathrm{BN}$ hosts of LEW kidneys also started to increase at the 6th day post-transplantation but the rise in serum urea concentration was not as steep. Hence, LEW kidneys residing in IgM-BN hosts were rejected in a slightly delayed fashion (mean rejection time (MRT) 9.3 days) which was significantly different from the MRT of 7.1 days observed with LEW kidneys transplanted into unmodified BN hosts $(P<0.04)$.

\section{Immunopathology of LEW kidneys rejected by $\operatorname{Ig} M-B N$ hosts}

Six LEW kidneys rejected by unmodified BN hosts and 7 LEW kidneys rejected by IgM-BN hosts were available for histological analysis (Table VI.I). All of these grafts were obtained by sacrificing the recipients when the urea concentration exceeded $400 \mathrm{mg} / 100 \mathrm{ml}$.

LEW kidneys rejected by unmodified BN hosts showed a vascular rejection characterized by patchy renal cortical necrosis and glomerular tuft necrosis in 5 out of 6 instances (Plate I, II). Only one out of 7 LEW kidneys rejected by IgM-BN rats showed such lesions (Table VI.1); precisely in this recipient BN anti LEW-E IgG antibody was demonstrable with a significant titer in the serum prior to sacrifice. Both LEW kidneys residing in unmodified as well as in $\operatorname{IgM}-\mathrm{BN}$ hosts showed comparable margination of mononuclear cells in the peritubular capillaries. The extravascularinterstitial mononuclear cell infiltrate in LEW kidneys rejected by IgM-BN rats was more extensive compared to that in LEW kidneys rejected by unmodified BN rats (Table VI.1, Plates III, IV and V).

PLATE I. LEW renal allograft rejected by an unmodified $B N$ recipient (HE, $\times 400)$. Patchy renal cortical necrosis is particularly well seen subcapsularly. Notice the necrotic proximal tubules; marginating leukocytes are observed in the peritubular capillaries.

PLATE 1I. LEW renal allograft rejected by an unmodified BN recipient (HE, $\times 400)$. Fibrinoid deposits are seen in the afferent arteriole $(D)$ and in the capillaries of a glomerulus in the outer cortex. These deposits were associated with patchy cortical necrosis (see Plate $\mathbb{1}$ ). 


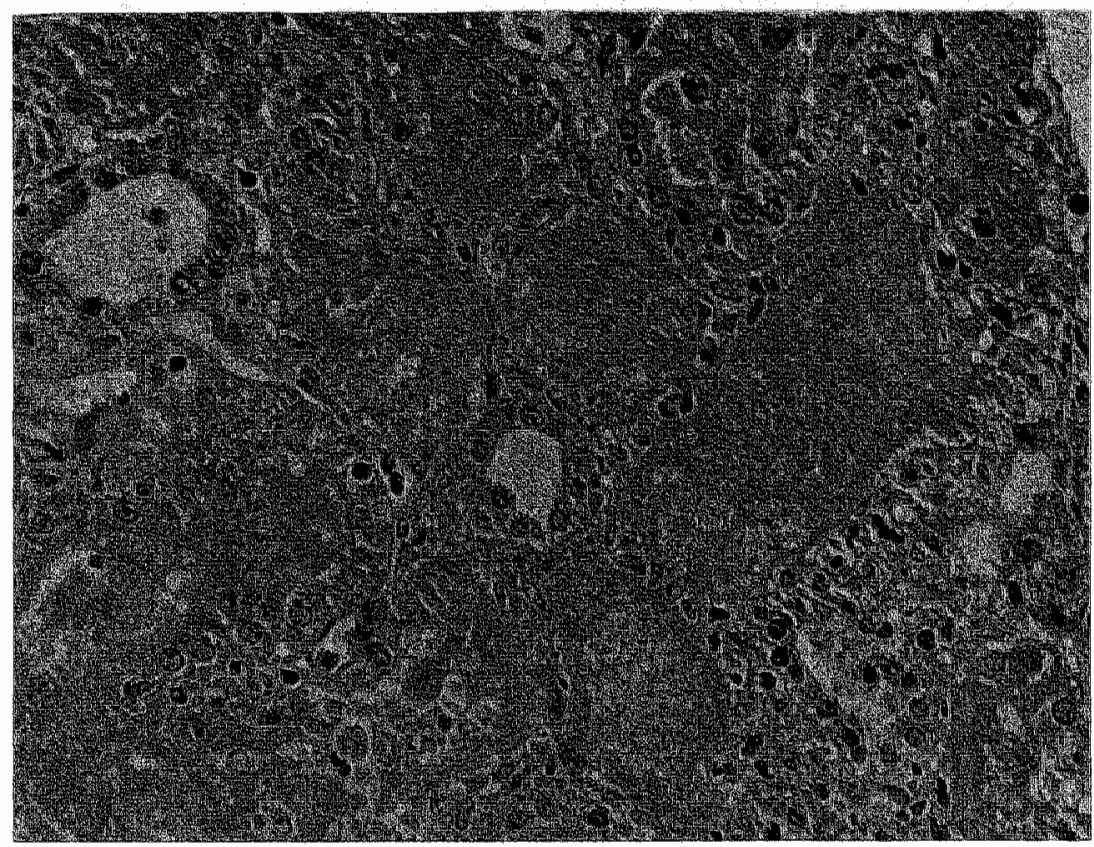

Plate I. For legend see p. 106.

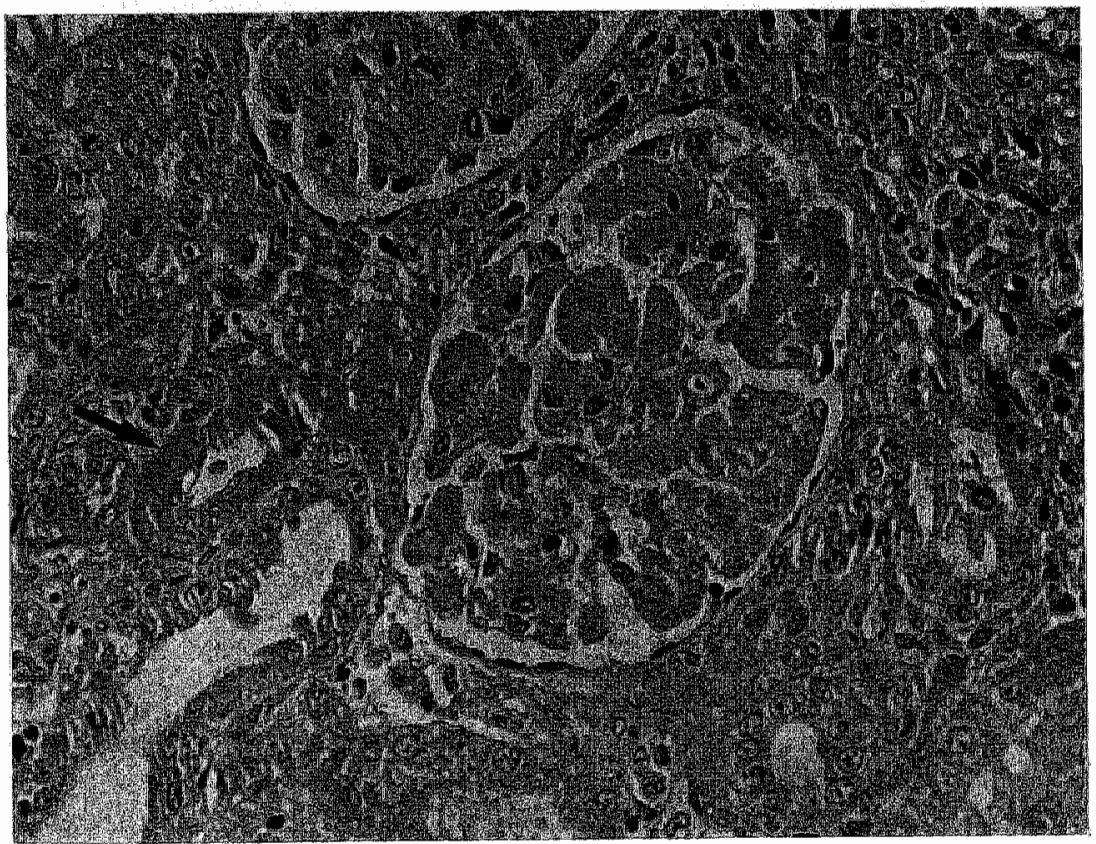

Plate 1I. For legend see p. 106. 


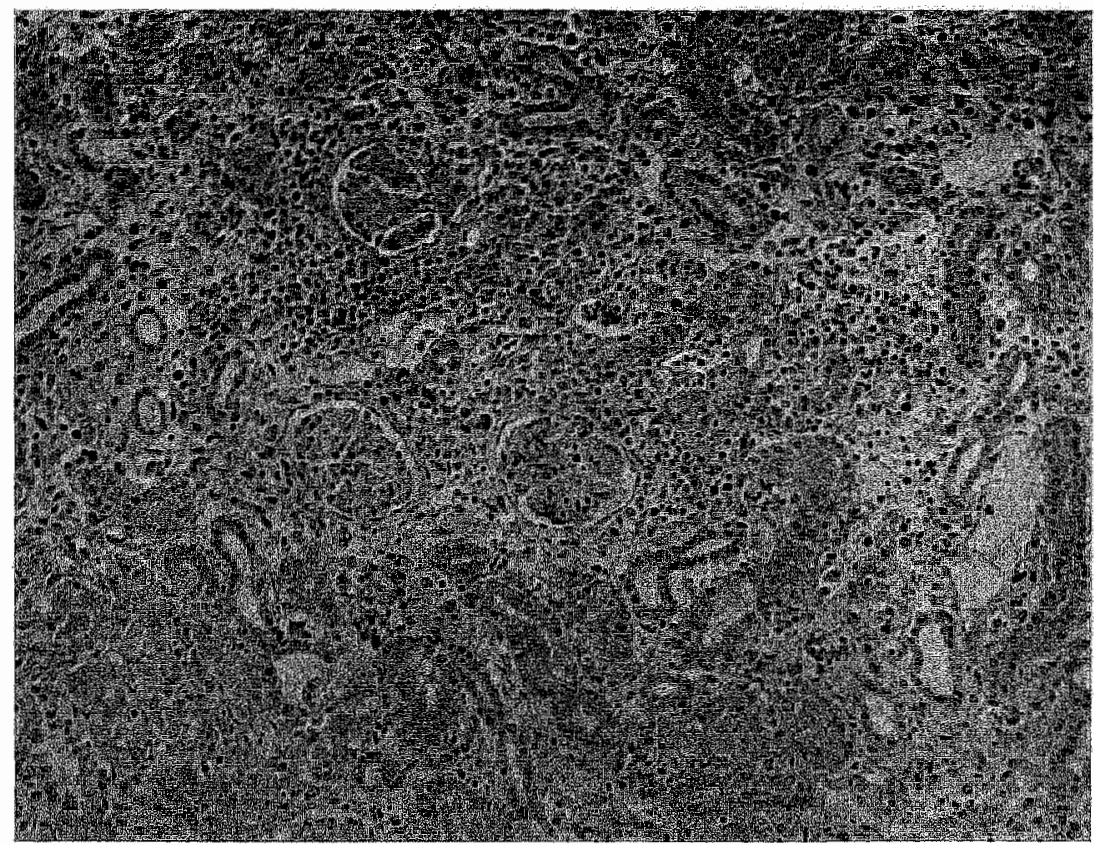

Plate IIT. For legend see p. 109.

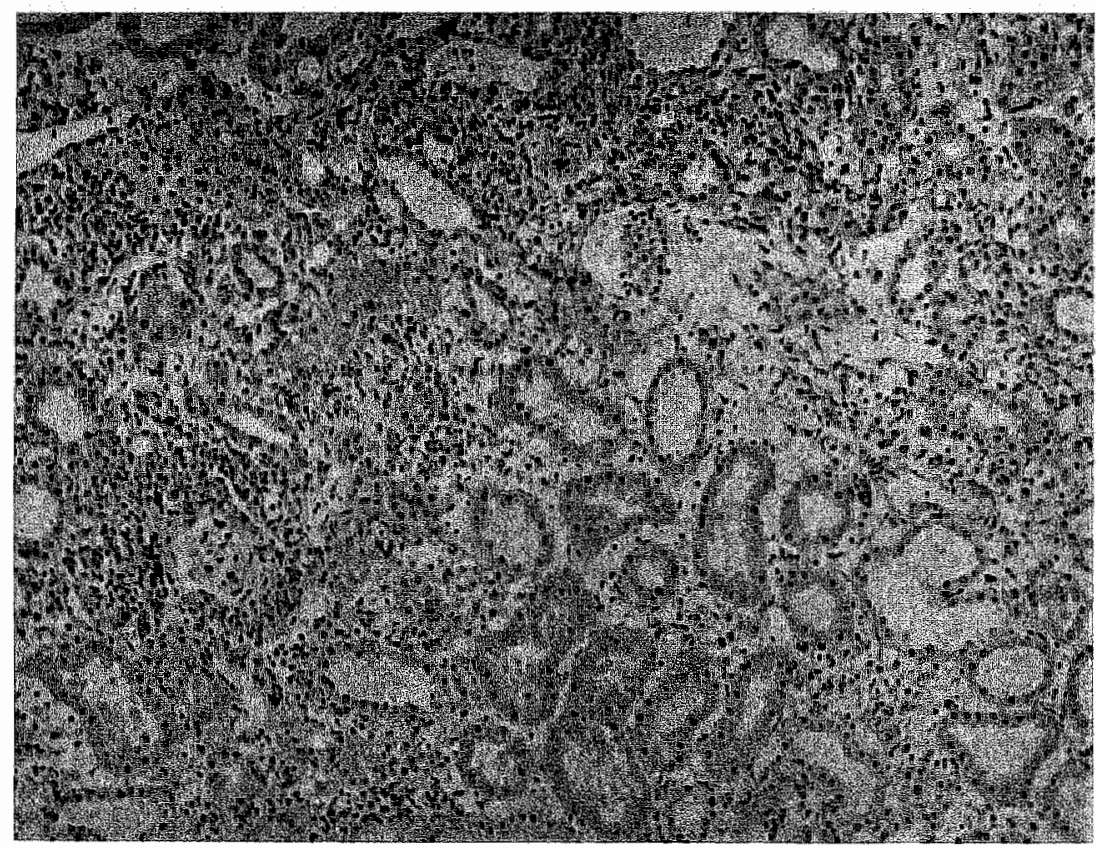

Plate IV. Fon legend see p. 109. 


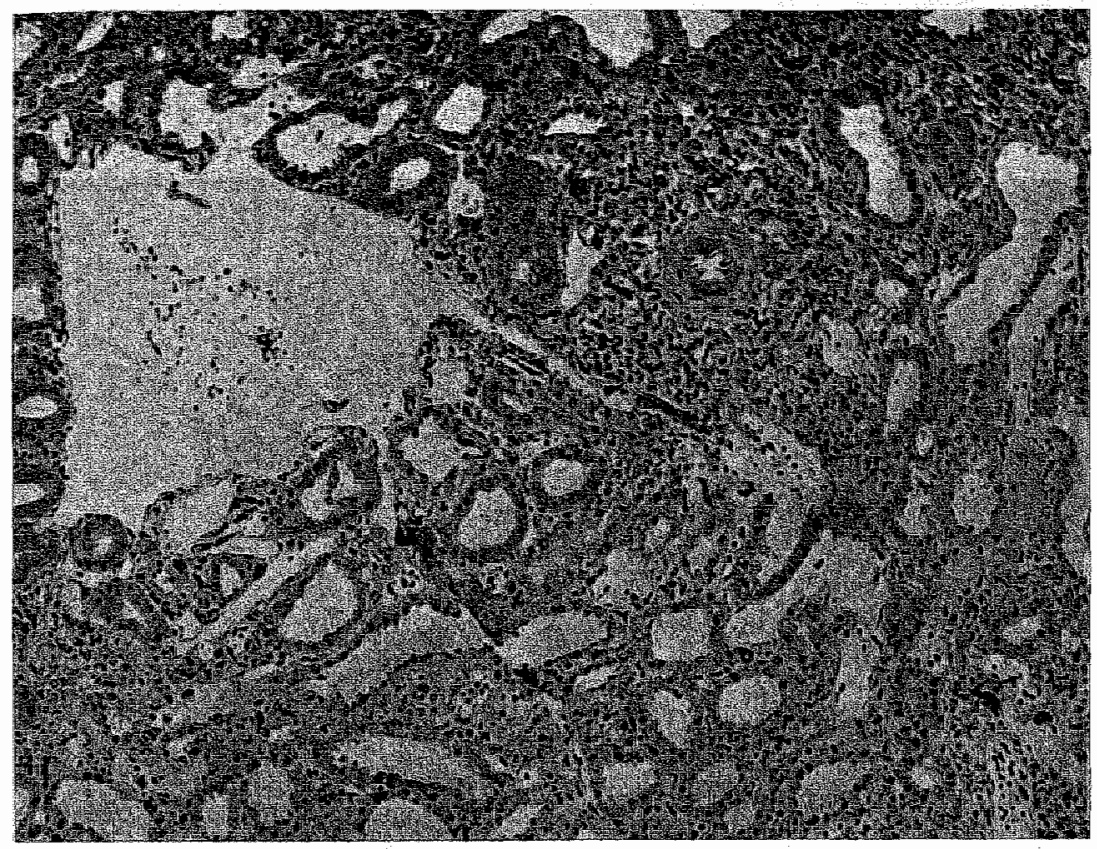

PLATE V. LEW renal allograft rejected by an IgM-BN recipient $(H E, \times 250)$. A well-developed, interstitially located mononuclear cell infiltrate is observed periarterially.

PLATE III. LEW renal allograft rejected by an unmodified BN recipient. (HE, $\times 120$ ). Severe interstitial edema is obserwed focally. Notice the well developed mononuclear cell infiltrate periglomerularly. Elsewhere in this kidney fibrinoid deposits and patchy cortical necrosis were seen (see Plates I and II).

PLATE IV. LEW renall allograft rejected by an IgM-BN recipient (HE, $\times 250)$. Interstitial edema is clearly seen in the absence of fibrinoid deposits in the afferent arterioles or glomeruli. Notice the well-developed interstitially located mononuclear cell infiltrate and the margination of these cells in the peritubular capillaries. 
By means of indirect immunofluorescence $\operatorname{IgM}$ was shown to be deposited along the glomerular capillary walls of all LEW renal grafts rejected by both unmodified and IgM-BN rats (Plate VI).

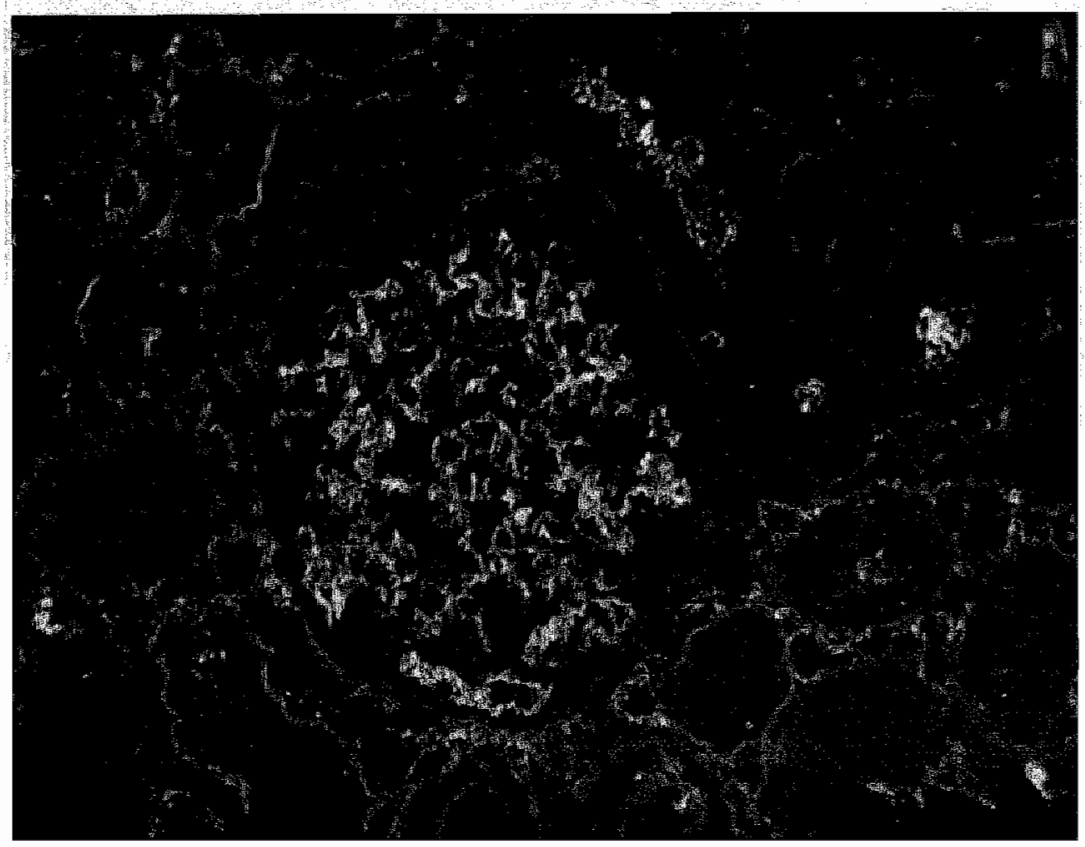

PLATE VI. LEW renal allograft residing for 5 days in an unmodified BN host (Indirect immunofluorescence technique, $\times 400$ ). IgM is deposited along the glomerular capillaries in an interrupted linear-like pattern. Deposition of IgM along the peritubular capillaries may indicate specific binding of $I \mathrm{gM}$ antibodies to the endothelium since background fluorescence for $\operatorname{lgM}$ was usually very low (see Plate VII).

Immunofluorescence detected along the peritubular capillary walls (Plate VI) may indicate binding of IgM antibodies to endothelial cells $(7,47)$ since aspecific background fluorescence was usually negligible (Cf. Plate VII). Deposition of IgG was not observed in the glomeruli of LEW kidneys rejected by IgM-BN hosts and frequently clearly seen in the glomeruli of LEW grafts rejected by unmodified BN rats. Because of the high background fluorescence however the presence or absence of small quantities of $\mathrm{IgG}$ deposits along the glomerular and peritubular capillary walls could not be demonstrated unequivocally. 
THE EFFECT OF ANTI LEW-IE IgM ANTIBODY

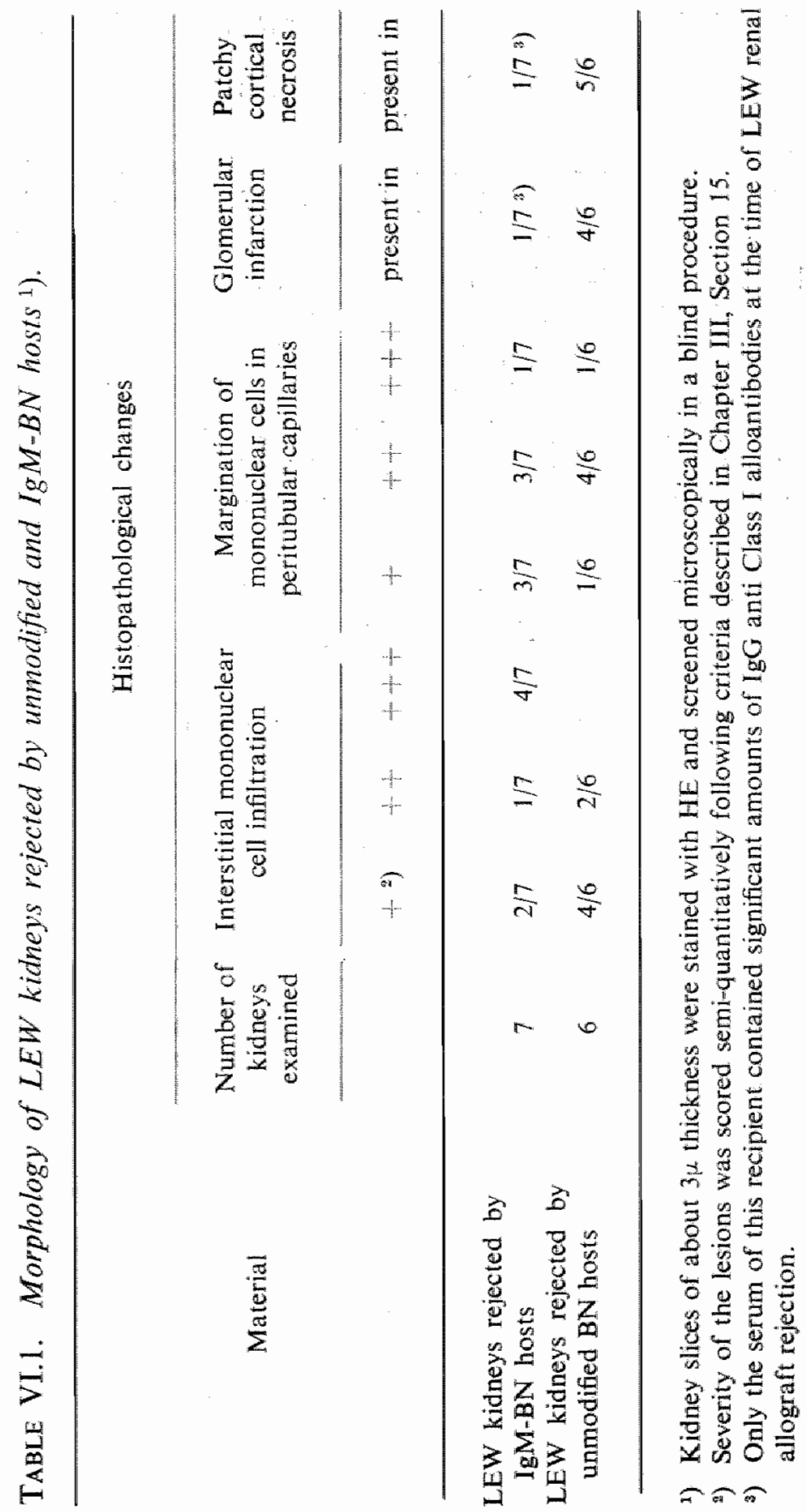


5 Cytoroxic $T$ cell response of $\mathrm{Ig} M-B N$ rats to $L E W$ renal grafts

Rejection of first set vascularized allografts is considered to be mediated in part by cytotoxic T lymphocytes (32). Thus, cytotoxic T cell responses were measured from the 4 th to the 10 th day posttransplantation in unmodified and IgM-BN hosts of LEW kidneys in order to establish whether or not enhanced survival of LEW renall grafts in IgM-BN hosts was due to a delay in the generation of cytotoxic T lymphocytes. For that purpose, nylon wool nonadherent cells were harvested from the spleens of BN recipients of LEW kidneys and assayed for cytotoxicity using ${ }^{51} \mathrm{Cr}$-labeled LEW thymocytes as targets. Spleen cell. suspensions from unmodified as well as IgM-BN hosts of LEW kidneys yielded comparable numbers of nylon wool non-adherent cells (Table VI.2).

TABLE VI.2. Yield of nylon wool non-adherent cells from the spleens of $\operatorname{Ig} M-B N$ unmodified $B N$ recipients of $L E W$ kidneys.

\begin{tabular}{ccc}
\hline \multirow{2}{*}{$\begin{array}{c}\text { Days after } \\
\text { transplantation }\end{array}$} & \multicolumn{2}{c}{ Number of cells harvested $\times 10^{-7}$ (mean \pm SD) } \\
\cline { 2 - 3 } & Unmodified BN & IgM-BN \\
\hline & & \\
5 & $13.0 \pm 6.3$ & $16.1 \pm 3.7$ \\
6 & $14.7 \pm 6.1$ & $17.8 \pm 2.4$ \\
7 & $16.8 \pm 7.5$ & $17.9 \pm 4.8$ \\
8 & $24.1 \pm 6.8$ & $18.1 \pm 2.7$ \\
9 & $10.5 \pm 4.8$ & $14.2 \pm 4.0$ \\
10 & $20.4 \pm 5.1$ & $19.1 \pm 5.3$ \\
& $14.6 \pm 3.4$ & $17.2 \pm 4.5$ \\
\hline
\end{tabular}

At the 4th day after transplantation $\mathrm{T}$ lymphocyte-mediated cytotoxicity was demonstrable in unmodified as well as in IgM-BN recipients of LEW renal grafts using LEW thymocytes as targets. In IgM-BN hosts $\mathrm{T}$ cell-mediated cytotoxicity increased thereafter to reach an acme on the 7th post-operative day; later the cytotoxic potential declined (Fig. VI.2). The kinetics of T lymphocytemediated cytotoxicity of unmodified recipients of LEW kidneys 
differed somewhat from the kinetics observed in IgM-BN hosts of LEW kidneys since a first acme of cytotoxicity was reached on the 5th day post-transplantation and a second one on day 7 after transplantation (Fig. VI.2). However, since the magnitude of the

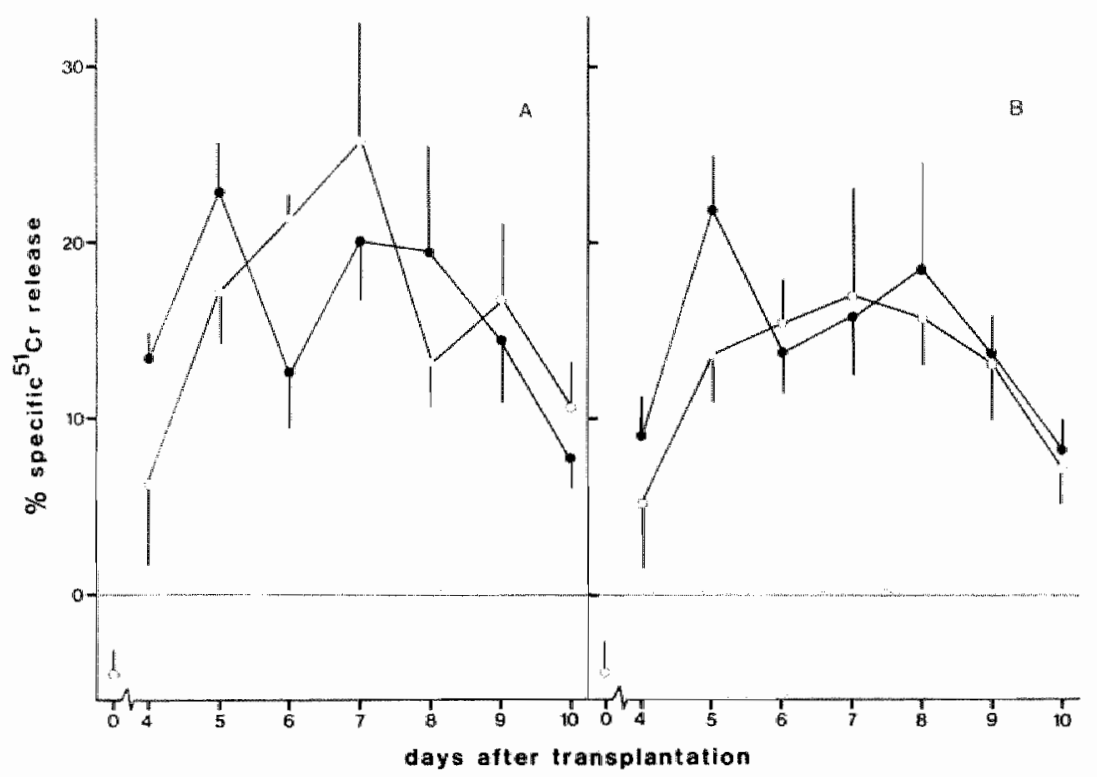

FIG. VI.2. Kinetics of the $T$ cell-mediated cytotoxic response of unmodified and IgM-BN hosts of LEW kidneys.

Splenic $T$ lymphocytes were isolated from the spleens of unmodified (e) and IgM-BN (O) hosts of LEW kidneys and assayed for their cytotoxic capacity on ${ }^{-1} \mathrm{Cr}$-labeled LEW thymocytes. Panel $\mathrm{A}$, effector : farget cell ratio $=$ $100: 1$; panel B, effector : target cell ratio $=200: 1$. Each point represents the mean cytotoxicity measured in $4 \mathrm{BN}$ hosts of LEW kidneys. Vertical bars represent SEM.

cytotoxic response in IgM-BN rats was only significantly lower than that in unmodified BN recipients of LEW kidneys at day 5 posttransplantation at an effector to target cell ratio of $200: 1$ $(P<0.05)$ the kinetics of the entire cytotoxic $\mathrm{T}$ cell responses in both groups of BN recipients of LEW kidneys were not considered to differ significantly. 


\section{Alloanibody response of $J g M-B N$ rats to $L E W$ renal grafts}

The finding that $\mathrm{T}$ lymphocyte-mediated cytotoxic responses elicited by LEW renal allografts in unmodified and $\mathrm{IgM}-\mathrm{BN}$ recipients of LEW kidneys did not differ significantly suggested the possibility that enhanced survival of LEW kidneys in IgM-BN hosts was due to a modified antibody response in these recipients. Therefore, alloantibody responses of graft recipients to donor Class I and Class II antigens were measured by means of hemagglutination and antibody-mediated complement-dependent cytotoxicity assays respectively. Cytotoxicity assays were performed on LEW Iymph node cells after removal of antibody to Class I antigens by absorption of BN anti LEW kidney alloantisera with LEW-E until void of hemagglutinins. In order to differentiate between IgM and IgG cytotoxic antibody the assay was performed using both guinea pig and rat complement since rat $\operatorname{IgM}$ antibodies fail to activate isologous complement in contrast to IgG antibodies (49). Antisera from $4 \operatorname{lgM}-\mathrm{BN}$ as well as from three unmodified recipients of LEW renal grafts were assayed at the 8 th day post-transplantation at the time of rejection of LEW kidneys by IgM-BN hosts.

In terms of cytotoxicity antisera harvested from IgM-BN hosts of LEw kidneys differed both qualitatively and quantitatively from antisera obtained from unmodified $\mathrm{BN}$ recipients. Using rat serum as a source of complement, whole serum from IgM-BN hosts of LEW kidneys lysed a higher percentage of LEW target cells than serum obtained from unmodified BN recipients of LEW grafts (Fig. VI.3A, top). After absorption with LEW-E cytotoxicity of serat from unmodified $\mathrm{BN}$, but not of IgM-BN recipients of LEW renal grafts was largely reduced (Fig. VI.3 B, top). These findings indicated that IgG cytotoxic antibodies were present in sera from both groups of recipients but were directed mainly to donor Class II antigens in IgM-BN and to donor Class I antigens in unmodified BN hosts of LEW kidneys. In the presence of guinea pig complement sera from both groups of recipients were about equally cytotoxic; cytotoxicity was only slightly reduced by absorption with LEW-E (Fig. VI.3 bottom panels). Thus, IgM and IgG cytotoxic antibodies were concluded to be directed almost exclusively to donor Class II antigens in IgM-BN recipients of LEW kidneys whereas in unmodified $\mathrm{BN}$ hosts $\operatorname{IgM}$ cytotoxic antibodies were probably mainly 


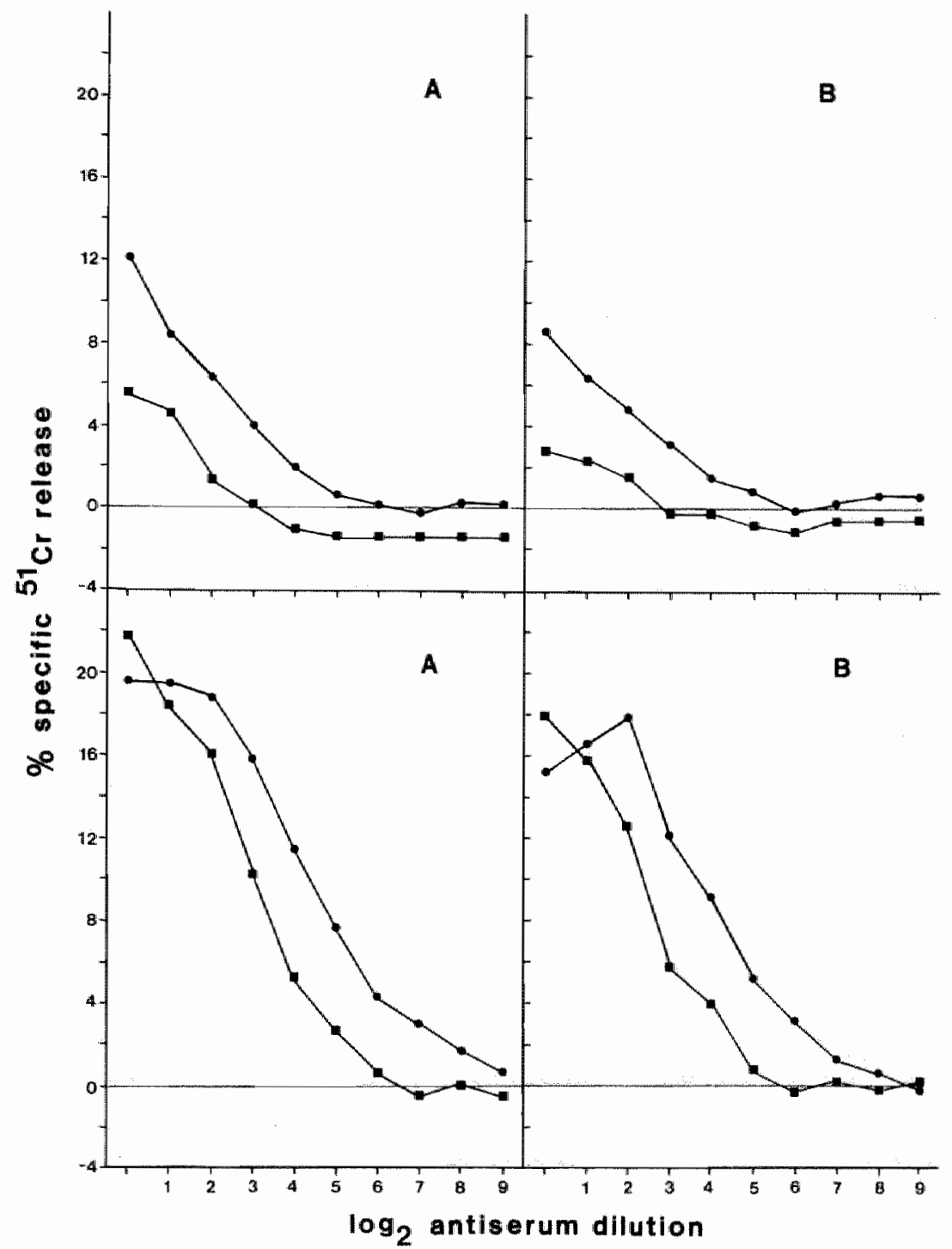

FrG. V1.3. Cytotoxic antibodies in sera obtained from unmodified and IgM-BN hosts of LEW kidneys

Sera obtained from three unmodified ( $D$ ) and $4 \mathrm{IgM}-\mathrm{BN}$ hosts (C) of LEW kidneys at 8 days after transplantation were assayed for cytotoxic antibodies on ${ }^{~} \mathrm{Cr}$-labeled LEW lymph node cells. Upper panels, in the presence of rat complement; lower panels, in the presence of guinea pig complement. A, neat antisera; $B$, antisera after absorption with LEW-E. 
directed to donor Class II antigens and IgG cytotoxic antibodies to donor Class I antigens.

The kinetics of $\operatorname{IgM}$ and $\operatorname{IgG}$ hemagglutinin production in unmodified and $\operatorname{IgM-BN}$ hosts of LEW renal grafts were in agreement with the findings described above. IgM hemagglutinins were first demonstrable in unmodified $\mathrm{BN}$ recipients of LEW kidneys on the 6th day post-operatively and increased in titer thereafter; IgG hemagglutinins were demonstrable commencing on the 8 th day after transplantation (Fig. VI.4). The titers of IgM hemagglutinins measured just prior to transplantation of LEW kidneys in IgM-BN recipients dropped to 0 within 96 hours after transplantation. At the 8 th or 10th day post-operatively $\operatorname{IgM}$ hemagglutinins were again demonstrable in sera of three out of 7 recipients although at low titers only. One IgM-BN recipient excepted that manufactured

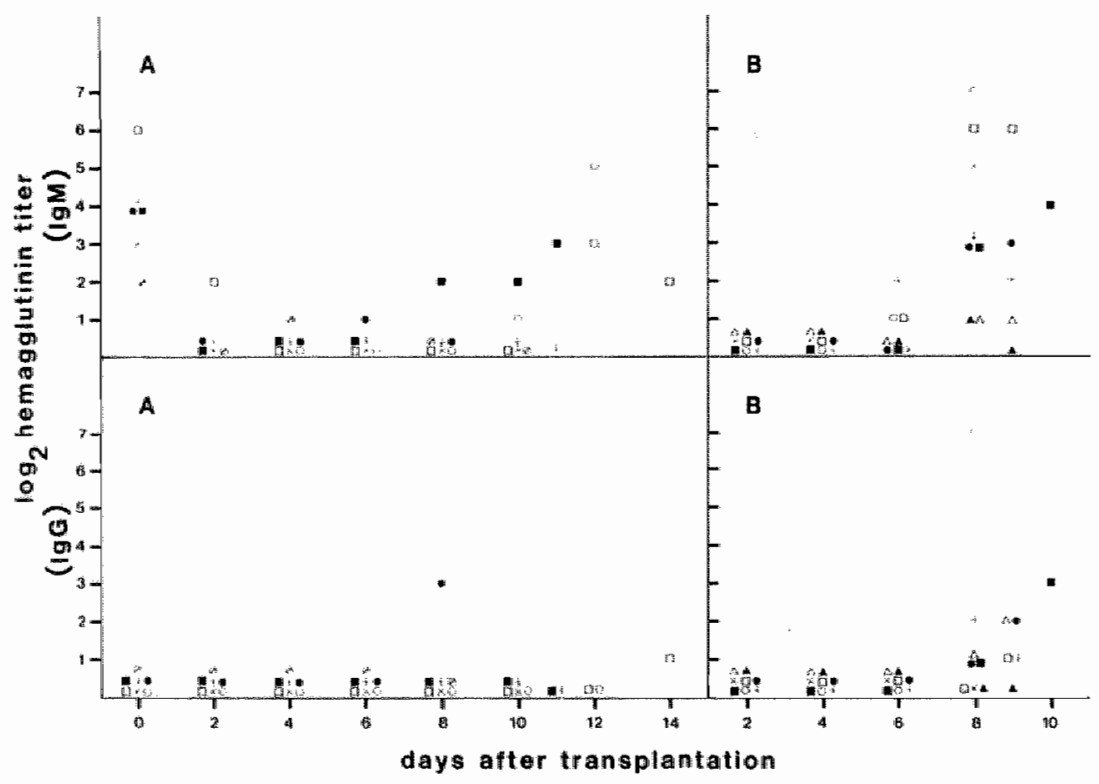

FIG. VI.4. Kinetics of anti LEW-E hemaggiutinin production in ummodified and $\operatorname{Ig} M-B N$ hosts of LEW kidneys.

Anti LEW IgM hemagglutinins (upper panels) and IgG hemagglutinins (lower panels) were monitored in sera from $\operatorname{IgM-BN}(\mathrm{A})$ and unmodified BN (B) hosts of LEW kidneys. Identical symbols in upper and lower panels refer to one serum sample. 
IgG hemagglutinins on day 8 after transplantation none of the IgM-BN recipients of LEW renal grafts developed significant titers of $\mathbb{I g G}$ hemagglutinins (Fig. VI.4).

\section{Binding of BN anti LEW-E IgM antibodies to LEW renal grafts}

In order to decide whether the absence of IgG antibody responses to donor Class I antigens in IgM-BN recipients of LEW renal grafts was brought about by a decrease in graft immunogenicity the binding of BN anti LEW-E IgM antibody to the LEW graft was assessed. Conceptually, graft immunogenicity might have been reduced because of binding of preexisting $\operatorname{lgM}$ antibodies to donor antigens exposed on the endothelial cells of the LEW kidney.

First, syngeneic BN as well as allogeneic LEW kidneys were grafted into IgM-BN rats and the hemagglutinin titers in the blood were monitored for 48 hours. Both syngeneic and LEw renal grafts caused a decrease in hemagglutinin titers although the decrease

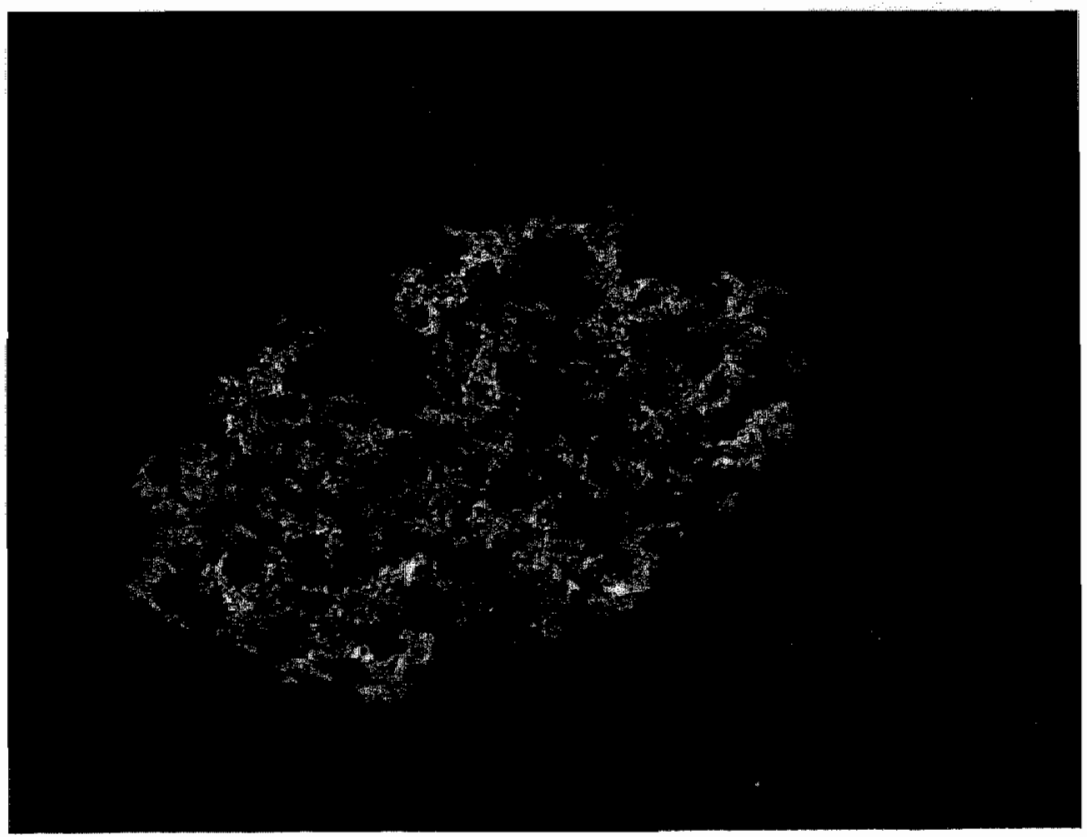

Plate VII. LEW remal allograft residing for 24 hours in an IgM-BN host (Indirect immunofluorescence technique, $\times 550$ ). IgM is deposited allongside the glomerular capillaries. 
brought about by syngeneic kidneys appeared less compared to LEW grafts (Table VI. 3). Next, binding of IgM immunoglobulins to the vasculature of the graft was assessed by indirect immunofluorescence. LEW renal grafts removed at 24 and 48 hours after transplantation showed clearcut deposition of $\operatorname{IgM}$ along the glomerular capillary walls (Plate VII). Recipient kidneys left in situ and LEW kidneys removed from unmodified BN hosts before the 5th post-operative day were always negative. Thus, binding of anti LEW-E IgM antibody could be involved in reduction of immunogenicity of LEW renal grafts inserted into IgM-BN recipients.

TABLE VI.3. Effect of insertion of $L E W$ and BN kidney grafts on the hemagglutinin titers in $\operatorname{Ig} M-B N$ host ${ }^{1}$ ).

\begin{tabular}{ccccc}
\hline Recipient & $\begin{array}{c}\text { Kidmey donor } \\
\text { strain }\end{array}$ & $\begin{array}{c}\text { Hours of } \\
\text { residence }\end{array}$ & $\begin{array}{c}\text { Titer }^{2} \text { ) prior } \\
\text { to } \\
\text { transplantation }\end{array}$ & $\begin{array}{c}\text { Titer at } \\
\text { termination of } \\
\text { the experiment }\end{array}$ \\
\hline & LEW & 3 & 16 & 4 \\
1 & LEW & 24 & 32 & 16 \\
2 & LEW & 48 & 16 & 0 \\
3 & LEW & 48 & 64 & 4 \\
4 & BN & 48 & 8 & 4 \\
6 & BN & 48 & 256 & 64 \\
\hline
\end{tabular}

1) LEW and BN kidneys were inserted into IgM-BN recipients in which IgM hemagglutinin titers were determined just prior to and at 3,24 or 48 after transplantation.

y) IgM themagglutinin titers were determined by the direct hemagglutination assaty.

8 Effect of $B N$ anti $L E W-E$ IgM antibodies on the recirculation of LEW lymphocytes

BN rats sensitized by one infusion of $1 \times 10^{8}$ LEW-E to produce anti LEW IgM hemagglutinins readily respond to a second infusion of LEW-E with IgG hemagglutinins (Chapter IV). Since anti LEW-E IgM antibody responses were delayed and $\operatorname{IgG}$ antibody responses suppressed in most IgM-BN recipients of LEW kidneys, sensitization 
of the recipient for an anamnestic anti LEW hemagglutinin response by the LEW renal graft was interfered with. 'Passenger' leukocytes coming out of a renal graft and homing to the recipient's lymphoid organs (50) have been suggested to play a major role in the early sensitization of the recipient $(17,55)$. Therefore renal allograft immunogenicity might have been modified by opsonization of mobile passenger lymphocytes by BN anti LEW-E IgM alloantibodies. In order to examine this hypothesis $6 \mathrm{IgM}-\mathrm{BN}$ rats and three unmodified $\mathrm{BN}$ rats were given $1 \times 10^{7}{ }^{51} \mathrm{Cr}$-labeled LEW thoracic duct lymphocytes i.v. Of these 6 IgM-BN rats two were given a LEW renal allograft and one a $\mathrm{BN}$ renal allograft 1.5 to 3.5 hours prior to the infusion of the ${ }^{51} \mathrm{Cr}$-labeled thoracic duct lymphocytes. LEW renal allografts were inserted because these grafts may interfere with the opsonization of the labeled LEW lymphocytes by BN anti LEW-E IgM alloantibody by virtue of the fact that LEW renal grafts bind these alloantibodies as well. The BN renal isograft was inserted as a control for the influence of the

TABLE VI.4. Effect of preexisting anti LEW-E IgM antibody on the disiribution of LEW lymphocytes in $B N$ rats ${ }^{1}$ ).

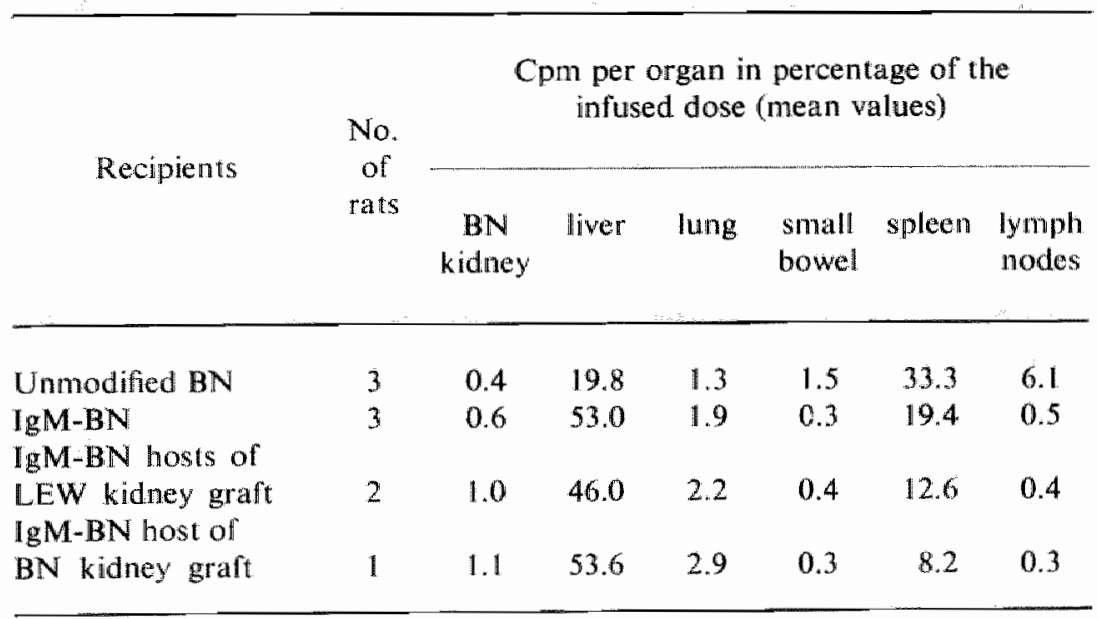

1) Ten million ${ }^{51} \mathrm{Cr}$-labeled LEW thoracic duct cells were infused into unmodified and $\operatorname{lgM}-\mathrm{BN}$ rats. Two out of $6 \mathrm{IgM}-\mathrm{BN}$ rats used were grafted with a LEW kidney just prior to infusion of LEW thoracic duct cells; one $\operatorname{IgM}-\mathrm{BN}$ rat received a syngeneic kidney. 
surgical procedure. All IgM-BN rats were sacrificed 24 hours postoperatively and the radioactivity in various organs was determined.

Distribution of LEW thoracic duct cells in IgM-BN hosts was markedly different from that observed in unmodified BN rats. Compared to the distribution of LEW lymphocytes in unmodified BN rats migration of LEW thoracic duct cells to the lymph nodes, spleen, and small bowel was significantly reduced in $\operatorname{IgM}$-BN rats $(P<0.005)$. The presence of a LEW or BN kidney graft in the IgM-BN recipients did not alter the distribution pattern as found in non-grafted IgM-BN rats (Table VI.4). This experiment suggested that mobile 'passenger lymphocytes' coming out of LEW kidneys residing in IgM-BN hosts do not contribute to the sensitization of these recipients because they are opsonized by BN anti LEW-E IgM alloantibodies and trapped in the liver ( 8 ).

\section{Discussion}

Rejection of LEW renal allografts by IgM-BN rats commenced at the same time after transplantation as the rejection of LEW kidneys by unmodified $\mathrm{BN}$ rats but lacked the vigour of the latter thus bringing about a slightly enhanced renal allograft survival. This lack of vigour was not associated with a diminution of cellmediated cytotoxicity nor with a diminished cytotoxic antibody response to Class II alloantigens but with an absence of $\mathrm{IgG}$ alloantibodies to Class I alloantigens in 6 out of 8 instances.

These observations are unique and cannot be compared with existing information on active $(25,42)$ and passive $(6,10,38,39$, $5 l, 56)$ enhancement models of rat renal allografts for three reasons. First, in most models of active and passive enhancement of rat renal allografts, recipients were sensitized with both Class I and Class II antigens and at least in passive enhancement models the prolonged renal allograft survival has been reported to be associated with a delayed elicitation of cellular cytotoxicity $(6,10)$ and with a suppression of the cytotoxic antibody response to Class II antigens (56). Second, in a study on active enhancement of rat renal allografts with Class I alloantigens a markedly prolonged renal allograft survival was observed (28); in that study the immune response of the sensitized recipient of the renal allograft was not measured. Finally, the strain combination worked with by us is 
unusual since almost invariably LEw rats are used as recipients ( 6 , $25,42,56)$ and not as donors.

The enhanced survival of LEW renal grafts in IgM-BN recipients. is unlikely to be caused by suppressed $T$ cell-mediated immunity for both in vitro cytotoxicity of immune spleen cells from IgM-BN recipients of LEW kidneys and the mononuclear infiltrates in the LEW kidneys inserted into IgM-BN recipients did not differ from non-sensitized controls. IgM antibodies to Class I alloantigens are capable of binding to renal endothelial cells (7) and cytotoxic $T$ cells are most likely directed to Class I alloantigens (2). Nevertheless it is unlikely that $\operatorname{IgM}$ antibodies to Class I alloantigens protected the graft against injury by cytotoxic $\mathrm{T}$ lymphocytes with a similar specificity $(14,20)$ by virtue of the fact that they blocked antigenic sites since $\mathrm{BN}$ anti LEW-E IgM antibodies disappeared. from the blood of sensitized BN rats 48 hours after insertion of a LEW renal allograft and about two days before cytotoxic T lymphocytes became demonstrable; this observation together with the fact that antigen-bound early $\operatorname{IgM}$ alloantibodies are rapidly degraded in vivo (7) makes it very unlikely that a blockade of $T$ cell immunity by target cell-bound IgM alloantibodies played a role in the diminished vigour of the rejection which has its onset at the 5 th day post-operatively.

There is on the other hand good evidence that the decreased vigour of rejection of LEW kidneys by IgM-BN hosts is caused by a suppression of anti Class I alloantibody synthesis. First, hemagglutination assays showed that anti LEW-E IgM antibody responses developed in a delayed and depressed fashion in $\operatorname{IgM}-B \mathrm{~N}$ recipients of LEW kidneys compared to unmodified controls and that anti LEW-E IgG alloantibody responses were absent from IgM-BN recipients of LEW kidneys in 6 out of 8 instances at the time of LEw renal allograft rejection. The absence of $\operatorname{IgG}$ alloantibody to Class I donor antigens was confirmed in antibody-mediated complement-dependent cytotoxicity assays which showed at the same time that cytotoxicity of alloantibodies against Class II antigens in sera of IgM-BN recipients of LEW kidneys was equal to or exceeded that of unmodified controls. Second, histological study of seven LEW kidneys rejected by IgM-BN hosts showed the presence of vasculonecrotic lesions precisely in one kidney rejected by an IgM-BN recipient manufacturing significant amounts of anti 
LEW-E IgG. Unfortunately, the LEW kidney rejected by the IgM-BN host responding with anti LEW-E IgG antibody with a low titer was not available for histological evaluation. How the interference with the anamnestic response to Class $\mathbb{I}$ antigens in $\operatorname{IgM}-\mathrm{BN}$ recipients of LEW kidneys is brought about is not clear although opsonization of 'mobile passenger leukocytes' undoubtedly occurs. If however the lack of a passenger lymphocyte-mediated allogeneic effect (3) in IgM-BN recipients of LEW kidneys accounted for the depression of humoral responsiveness to donor Class I antigens the 'allogeneic factor" must have influenced specifically this humoral immune response of the host for the humoral response to Class II antigens was not influenced. For this hypothesis no evidence in favour or against - exists in the literature. An alternative hypothesis addresses itself to the shedding of IgM antibody-Class I antigen complexes from the surface of the endothelial target cells which may circulate in the recipient (46). Although immune complexes containing $\mathrm{IgG}$ antibody have been shown to suppress immune responses specifically (40) $\mathrm{IgM}$ antibody-antigen complexes are probably not able to act in a similar fashion because $\mathrm{Fc}$ receptors of cells capable of suppression of immune responses do not bind the $\mathrm{Fc}$ portion of $\operatorname{IgM}(4,37,5 I)$. In addition, due to its large dimensions IgM molecules are not likely to recirculate from the blood plasma into the interstitial fluid, let alone when complexed with antigen (7). Thus, it is difficult to imagine how antigen-IgM antibody complexes could suppress antibody responses to donor Class I antigens that are most likely to develop in the splenic parenchyma.

Although depression of antibody responses to LEW Class II antigens in IgM-BN recipients of LEW kidneys cannot be satisfactory explained it may well account for the prolongation of kidney graft survival in these recipients. Anti donor IgG antibody has been suggested to mediate vasculitis in the graft which in turn contributed significantly to rejection ( $I$ ). The failure to observe glomerular and cortical necrosis in LEw kidneys rejected by IgM-BN rats correlated precisely with the absence of $\operatorname{IgG}$ antibody responses to donor Class $I$ antigens. This finding is in agreement with a role for anti donor Class I antibody in mediating vasculonecrotic lesions in renal allografts. It should be noticed that $\operatorname{IgG}$ antibodies to donor Class II antigens demonstrable in sera from IgM-BN 
hosts of LEW kidneys by cytotoxic assays were obviously unable to substitute for IgG antibody to donor Class I antigens in mediating vasculitis. This may reflect a low density of Class $\mathbb{\|}$ antigens on vascular endothelial cells (47) but it does not exclude the possibility that IgG antibody to Class I antigens acts in concert with IgGr antibody to Class 11 antigens in mediating vasculonecrotic lesions in unmodified rejection ( $3 I)$.

In spite of the absence of anti LEW IgG hemagglutinin responses in IgM-BN hosts of LEw kidneys rejection occurred within 14 days, indicating that $\operatorname{lgG}$ antibody-mediated vasculitis is not the sole mechanism capable to effect rejection of renal grafts residing in IgM-BN hosts. The nature of the mechanism(s) mediating rejection in the absence of $\operatorname{IgG}$ antibody to donor Class I antigens was not elucidated.

\section{Summary}

Rejection of LEW renal grafts residing in unmodified and IgM-BN recipients started at the same time post-operatively but proceeded more slowly in IgM-BN hosts. LEW renal grafts residing in unmodified and IgM-BN rats elicited cellular immune responses and IgM antibody responses to LEW Class III antigens in an identical fashion. Prolonged survival of LEW kidneys in IgM-BN rats was most likely to be due to absence of IgG antibody to donor Class I antigens. The same IgG antibodies appear to account for the vasculonecrotic lesions observed in LEW kidneys rejected by unmodified BN hosts. The mechanisms by which antibody responses to LEW Class II antigens were depressed in IgM-BN rats remain to be determined.

Although the absence of IgG antibodly brought about the slightly prolonged survival of LEW renal grafts in IgM-BN hosts it did not prevent the grafts from being rejected. Thus, mechanisms acting independently from $\operatorname{IgG}$ antibody to Class I antigens are capable to effect rejection of LEW renal grafts residing in IgM-BN hosts. 


\section{References}

1 Abeas, A. K., Corson, J. M., Carpenter, C. B., Salvanek, E. G., MerilL, J. P. and DAMNIN, G. J. : Immunologic enhancement of rat renal allografts. II. Immunohistology of acutely rejecting and passively enhanced grafts. Am. J. Paihol. 75: 271, 1974.

2 Alter, B. J., Schendel, D. J., BACH, M. L., BACH, F. H., Klein, J., and STIMPFLINO, J. H.: Cell-mediated lympholysis: Importance of serologically defined H-2 regions. J. Exp. Med. 137: 1303, 1973.

3 Altman, A, Cardenas, J. M., Bechtold, T. E, and Katz, D. H.: The biological effects of allogeneic effect factor on $T$ lymphocytes. I. The mitogenic activity and the autonomous induction of cytotoxic T lymphocytes by AEF. J. Immunol. 124: 105, 1980.

4 Andersson, B., Skoglund, A. C., and Rosen, A. : Functional characterization of mouse T lymphocytes with IgM-Fc receptors. $J$. Immunol. 123. $1936,1979$.

5 Asher, N. L., Simmons, R. L., Fryd, D., Noreen, H., and Najarian, J. S.: Effect of HLA-A and B matching on success of cadaver grafts at a single center. Transplantation 28: 172, 1979.

6 Biesecker, J. L., Fitch, F. W., Rowly, D. A., and Stuart, F. P. : Cellular and humoral immunity after allogeneic transplantation in the rat. 1II. The effect of passive antibody on cellular and humoral immunity after allogeneic renal transplantation. Transplantation $16: 432$, 1973.

7 BREDA VRIESMan, P. J. C. VAN, and FELdman, J. D. : y M alloantibodies elicited by first-set renal allografts: in vivo and in vitro studies. J. Immunol. $108: 1188,1972$.

8 Breda Vruisman, P. J. C. van, Swanen-Sterag, L., and Vlek, L. F. M. : Cytotoxic and enhancing properties of early $\gamma \mathrm{M}$ alloantibodies elicited by first set renall allografts. Transplantation $20: 385,1975$.

9 Broyer, M., Gagnadoux, M. F., Beurton, D., Pascal, B., Busson, M., and Hors, J. : Importance of HLA-A,B matching in kidney transplantation in children. Transplantation $30: 310,1980$.

10 Burgos, H., French, M. E., and Batchelor, J. R. : Humoral and cellmediated immunity in rats with enhanced kidney allografts. Transplantation $18: 328,1974$.

11 DAvies, D. A. L., and Alkins, B. J. : What abrogates heart transplant rejection in immunological enhancement? Nature 247: 294, 1974.

12 Davies, D. A. L., and Staines, N. A. : A cardinal role for I-region antigens (Ia) in immunological enhancement, and the clinical complications. Transplant. Rev. 30:18, 1976. 
13 Davis, W. C., and MCKenziE, I. F. C. : Immunological enhancement can be mediated by anti-la and anti-K,D antibodies. Tronsplantation $29: 77,1980$.

14 EpstelN, S. L., OzATO, K, and SACHS, D. H. : Blocking of allogeneic cell-mediated lympholysis by monoclonal antibodies to $\mathrm{H}-2$ antigens. J. Immumol. $125: 129,1980$.

15 Es, A. A. van, Marquet, R. L., Rood, J. J. Van, Kallf, M. W., and BALNER, H. : Blood transfusions induce prolonged kidney allograft survival in rhesus monkeys. Lancet $I: 506,1977$.

16 FABre, J. W., and Morris, P. J. : The effect of donor strain blood pretreatment on renal allograft rejection in rats. Transplantation 14: $608,1972$.

17 Fabre, J. W., and Morris, P. J. : The role of passenger leukocytes in the rejection of renal allografts of the rat. Transplantation 15:631, 1973.

18 Fabre, J. W., Bishop, M., Sen, T., McKenzie, J., Williams, K. A., Denton, T. G., Millard, P. R., and Moriris, P. J. : A study of three protocols of blood transfusion before renal transplantation in the dog. Transplantation 26:94, 1978.

19 Fauchet, R., Genetet, B., Campion, J.-P., Watelet, J., Minet, J., CARTIER, F., and LAUNOIS, B. : Occurrence and specificity of anti-B lymphocyte antibodies in renal allograft recipients. Transplantation 30 : 114,1980 .

20 Feighery, C. $F_{n}$, and Stastny, P. : Cell-mediated cytotoxicity against HLA-D-region products expressed in monocytes and B-lymphocytes. 1. Blocking by unlabeled cells and inhibition by antisera. Immunogenerics $10: 31,1980$.

21 Gailiunas, P. Jr., Suthantiran, M., Bush, G. J., Carpenter, C. B., and Garovor, M. R.: Role of humoral presensitization in human renal transplant rejection. Kidney Iht. $17: 638,1980$.

22 Gallico, G. G., Butcher, G. W, and Howard, J. C. : The role of subregions of the rat major histocompatibility complex in the rejection and passive enhancement of renal allografts. $J$ Exp. Med. $149: 244$, 1979.

23 Garovor, M. R., Strom, T. B., Gribik, M., and Carpenter, C. B.: Antibody-dependent lymphocyte-mediated cytotoxicity (Ab-LMC), definition of the ' $\mathrm{K}$ cell' in the rat. Transplantation $22: 367,1976$.

24 Ghebreaniwit, B., Medicus, R. G., and Müller-Eberhard, H. J. : Potentiation of antibody-dependent cell-mediated cytotoxicity by target cell-bound C3b. J. Immunol. 123: 1285, 1979.

25 Guttmann, R. D., Lindquist, R. R., Kawabe, K., and Ockner, S. A. : Renal transplantation in the inbred rat; further obserwations on the 
induction of enhancement by active immunization. Transplantarion 13 : 15, 1972 .

26 HAYRY, P., WILLEBRAND, E. VON, and ANDERSSON, L. C. : Expression of HLA-A,B,C and -DR locus antigens on human kidney endothelial, tubular and glomerular cells. Scand. J. Immunol. II: 303, 1980.

27 HOOFF, J. P. VAN, HOOFF-EUKENBOOM, Y. E. A. VAN, KALFF, M. W. GRAEFF, J. DE, and ROOD, J. J. VAN: Kidney graft survival, clinical course, and HLA-A, B and D matching in 208 patients transplanted in one center. Transplant. Proc. $11: 1291,1979$.

28 JEEKEL, J., DONGEN, J. VAN, MAjoOR, G., and HARDER, F. : Enhancement of rat renal allograft with antibodies directed against erythrocyteassociated antigens (EAA). Transplant. Proc. 9: 969, 1977.

29 Kissmeyer-Nielsen, F, Olsen, S., Petersen, V. P., and Fueldborg, O. : Hyperacute rejection of kidney allografts associated with pre-existing humoral antibodies against donor cells. Lancet I: 662, 1966.

30 LAMON, E. W. Shaw, M. W., GoOdson, S., Lidin, B., Walia, A. S., and Fuson, E. W. : Antibody-dependent cell-mediated cytotoxicity in the Moloney sarcoma virus system : differential activity of $\operatorname{lgG}$ and $\operatorname{lgM}$ with different subpopulations of lymphocytes. J. Exp. Med. 145 : $302,1977$.

31 Linscort, W. D. : Effect of celi surface antigen density on immunological enhancement. Nature 228: 824, 1970.

32 Maclennan, I., Balowin, W. M. III, and Tilney, N. L. : The effect of T-cell depletion on host responses to organ allografts. Transplant. Proc. II: 1435, 1979.

33 MArquet, R., and Heystek, G. : The induction and abolition of specific immunosuppression of heart allografts in rats by use of donor blood and cyclophosphamide. J. Immumol. 115: 405, 1975.

34 Marquet, R. L., Heystek, G. A., and Tinbergen, W. J. : Specific inhibition of organ allograft rejection by donor blood. Transplant. Proc. 3 : 708,1971 .

35 Medoyesi, Gi. A., Füst, G., Gergely, J., and BazIN, H. : Classes and subclasses of rat immunoglobulins: interaction with the complement system and with staphylococcal protein A. Immunochemistry 15: 125,1978 .

36 MORAEs, J. R., and STASTNY, P. : Eight groups of human endothelial cell alloantigens. Tissue Antigens $8: 273,1976$.

37 Moretta, L., Webr, S. R., Grossi, C. E., Lydrard, P. M., and Cooper, M. D. : Functional analysis of two human T-cell subpopulations: help and suppression of $B$ cell responses by $T$ cells bearing receptors for IgM or IgG. J. Exp. Med. 146: 184, 1977. 
38 Mullen, Y., and HuldemanN, W. H.: Kidney transplantation genetics and enhancement in rats. Transplant. Proc. $3: 669,1971$.

39 Mullen, Y., Raison, R., and HildemanN, W. : Cytotoxic vs. immunoblocking effects of specific alloantibodies - Effects of $\operatorname{lgM}, \mathrm{IgG}$ and $\operatorname{lgG}_{2}$ on rat kidney graft survival. Transplantation 24: 99, 1977.

40 OberbarnscheIDT, J., and KöLSch, E. : Direct blockadje of antigenreactive B-lymphocytes by immune complexes. An 'off' signal for precursors of IgM-producing cells provided by the linkage of antigen and Fo receptors. Immunology $35: 151,1978$.

41 Obertop, H., Bijnen, A. B., Vriesendorp, H. M., and Westbroek, D. L. : Prolongation of renal allografts survival in DLA tissue-typed beagles after third-party blood transfusions and immunosuppressive treatment. Transplantation $26: 255,1978$.

42 OCKNer, S. A., Guttmann, R. D., and Lindouist, R. R. : Renal transplantation in the inbred rat. XIII. Modification of rejection by active immunization with bone marrow cells. Transplantation 9: 30, 1970.

43 Opelz, G., and Terasaki, P. I. : Studies on the strength of HLA antigens in related donor kidney transplants. Transplantation 24:106, 1977.

44 Opelz, G., and Terasaki, P. I. : Dominant effect of transfusions on kidney graft survival. Transplantarion 29: 153, 1980.

45 Oriol, R., Opelz, G., Chun, C., and Terasaki, P. I. : Combined effects of HLA matching and age in renal transplantation. Transplantation 29 : 125,1980 .

46 Palosuo, T., Kano, K., Anthone, S., Gerbasi, J. R., and Milgrom, F. : Circulating immune complexes after kidney transplantation. Transplantation $21: 312,1976$.

47 Paul, L. C., Mllford, E. L., Paradysz, J. M., and Carpenter, C. B. : Alloantigens on the endothelium of rat kidneys. Transplant. Proc., in press.

48 ROOD, J. J. VAN, and BALNer, H., and MORRIS, P. J. : Blood transfusion and transplantation. Transplantation $26: 275,1978$

49 Ruszkiewicz, M. : Complement-activating properties of some rat alloantibodies. Transplantation $20: 227,1975$.

50 Schilfgaarde, R. Van, Hermans, P., Terpstra, J. I. , and Breda VriesMAN, P. J. C. VAN : Role of mobile passenger lymphocytes in the rejection of renal and cardiac allografts in the rat. Tramsplantarion 29 : 209,1980 .

51 Shaw, S., Pichler, W. J., and Nelson, O. L. : Fe receptors on human $T$ lymphocytes. III. Characterization of subpopulations involved in cell-mediated lympholysis and antibody-dependent cellular cytotoxicity. J. Immunol. 122 : 599, 1979. 
52 Sollulou, J. P., Carpenter, C. B., D'Apice, A. J., and Strom, T. B. : The role of non-classical, $\mathrm{Fc}$ receptor-associated, Ag-B antigens (Ia) in rat allograft enlancement. J. Exp. Med. $143: 405,1975$.

53 Soullnou, J. P., Peyrat, M. A, and Guenel, J. : Association between treatment-resistant kidney-allograft rejection and post-transplant appearance of antibodies to donor B lymphocyte alloantigens. Lancet $l$ : 354,1978 .

54 Strom, T. B., Carpenter, C. B., Garovoy, M. Abbas, A. K., Corson, J. M., and Soullibou, J. P. : Modification of the rat alloimmune response by enhancing antibodies and the role of blocking factors in the survival of renal grafts. Transplantation $20: 368,1975$.

S5 Stuart, F. P., Bastien, E., Holter, A., Fitch, F. W., and Elkins, W. L. : Role of passenger leukocytes in the rejection of renal allografts. Transplant. Proc 3: 461, 1971.

56 Suthantran, M., Catto, G. R. D., Kaldany, A., George, K., Garovoy, M. R., Strom, T. B., and CARpenter, C. B. : Differential antibody response to $\mathrm{Ag}-\mathrm{B}$ (A-region) and $\mathrm{Ia}$ (B-region) antigens during enhancement of rat renal allografts. Transplantation $28: 4,1979$.

57 Thomas, J., Thomas, F., and Lee, H. M. : Studies of lymphocyte-dependent antibody in human chronic renal allograft rejection. Transplant. Proc. 9: 85, 1977.

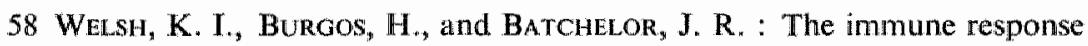
to allogeneic rat platelets: Ag-B antigen in matrix form lacking Ia. Eur. J. Immunol. $7: 267,1977$.

59 Williams, K. A., Hart, D. N. J., Fabre, J. W., and Morris, P. J. : Distribution and quantitation of HLA-A, B, C and DR (Ia) antigens on human kidney and other tissues. Transplantation 29: 274, 1980. 
CHAPTER VII

\section{THE EFFECT OF AN ESTABLISHED ANTI LEW-E IgG ANTIBODY RESPONSE ON THE REJECTION OF LEW RENAL GRAFTS BY BN RATS}

\section{Introduction}

The role of $\operatorname{IgG}$ antibodies in renal allograft rejection is probably different from that of IgM antibodies. IgG, but not IgM antibodies have been suggested to be associated with the acute vasculitis observed in terminally rejected first set allografts $(1,40)$. Vasculitis may be caused by $\operatorname{IgG}$-, and not by $\operatorname{IgM}$ antibodies because of the different biological characteristics of antibodies residing in each immunoglobulin class. IgG antibodies are purported to be superior to IgM antibodies in activating homologous complement (38) and in mediating antibody-dependent cellular cytotoxicity (ADCC) (35). On the other hand, passive enhancement studies showed IgG antibodies to be far more effective than IgM antibodies in inducing prolonged survival of renal allografts (12).

The present study takes advantage of the fact that IgG antibodies to LEW-E-associated antigens - including antibodies to Class I antigens - could be reproducibly elicited in BN rats. Therefore, the effect of an established IgG response to LEW-E on the rejection of LEW renal grafts by BN rats has been studied.

\section{Experimental protocol}

IgG antibody responses to LEW Class I antigens were elicited by three biweekly infusions of $1 \times 10^{8}$ LEW-E administered to BN rats commencing at two to three months of age. LEW kidneys were inserted into $\mathrm{BN}$ ant $\mathrm{LEW}-\mathrm{E} \mathbb{I g G}(\mathrm{IgG}-\mathrm{BN})$ responders at 11-15 days after the last infusion of LEw-E.

\section{Survival of LEW renal grafts in IgG-BN hosts}

Both the onset and the endpoint of rejection of LEW renal grafts as judged by the serum urea concentration were observed earlier 
in most IgG-BN hosts when compared to the kinetics of rejection in unmodified BN recipients. Serum urea concentrations exceeded $215 \mathrm{mg} / 100 \mathrm{ml}$ on day 4 post-transplantation in three out of 7 IgG-BN recipients and were over $252 \mathrm{mg} / 100 \mathrm{ml}$ on day 6 after

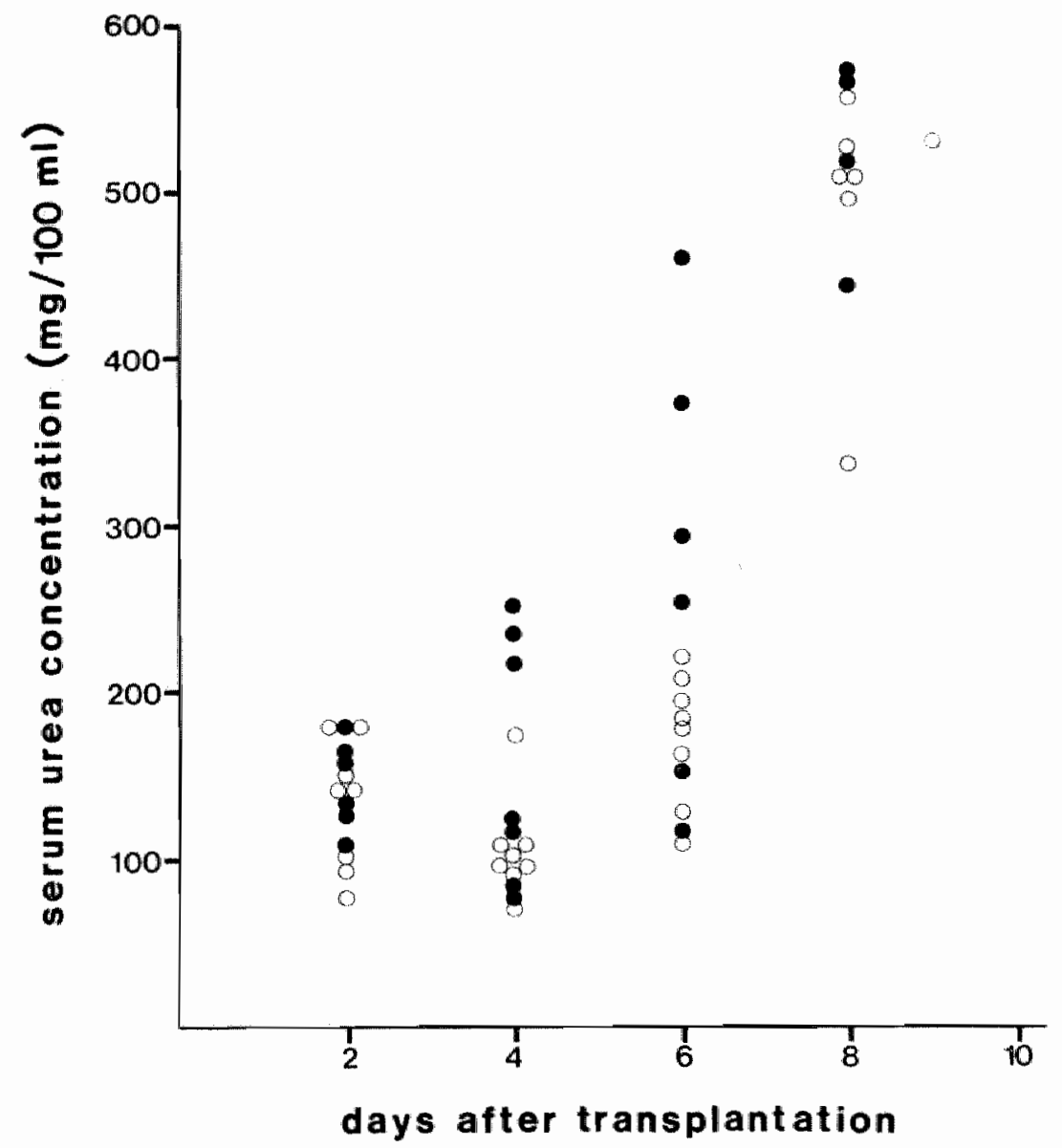

FIG. VII.I. Serum urea concentrations of unmodified and $\lg G-B N$ hosts of LEW kidneys.

- IgG-BN hosts of LEW kidneys; 0 , unmodified BN hosts of LEW kidneys. A serum urea concentration exceeding $400 \mathrm{mg} / 100 \mathrm{ml}$ was equated with rejection. The serum urea concentration of one IgG-BN recipient was not measured on day 2 after transplantation but was as low as $73 \mathrm{mg} / 100 \mathrm{ml}$ on day 4. 
transplantation in 5 out of 7 IgG-BN recipients. For comparison, serum urea concentrations in all unmodified recipients of LEW kidneys were less than $178 \mathrm{mg} / 100 \mathrm{ml}$ on day 4 , and less than $225 \mathrm{mg} / 100 \mathrm{ml}$ on day 6 post-operatively (Fig. VII.1). Thus, the onset of rejection was as early as three or 4 days after transplantation for three IgG-BN hosts of LEW kidneys and on the 5th or 6th day post-operatively for the remaining IgG-BN recipients. The MRT of LEW kidneys residing in IgG-BN recipients was shortened to 6.6 days when compared to the MRT of 7.1 days for LEW grafts residing in unmodified BN hosts; the difference between the MRT's of both groups of kidney graft recipients was statistically significant $(P<0.02)$.

\section{Immunopathology of LEW kidneys rejected by IgG-BN hosts}

Five LEW kidneys rejected by IgG-BN rats and 6 LEW kidneys rejected by unmodified BN hosts were available for histological analysis. These kidneys derived from recipients that where sacrificed because the serum urea concentration exceeded $400 \mathrm{mg} / 100 \mathrm{ml}$ of serum and from IgG-BN recipients that had died from uremia. Kidneys taken from IgG-BN recipients that had died because of uremia showed severe autolysis in two instances and were discarded. Thus the graft morphology of three LEW kidneys rejected by IgG-BN recipients was compared with the morphology of 6 LEW kidneys rejected by unmodified BN hosts in a blind procedure (Table VII.1). LEW kidneys rejected by IgG-BN rats showed little interstitial mononuclear cell infiltrate. Margination of mononuclear cells (lymphocytes and monocytes in the peritubular capillaries) was present in all instances (Plates VIII and IX) and

PLATE VIII. LEW renal allograft rejected by an IgG-BN recipient (HE, $\times 120$ ). In the cortico-medullary area extensive margination of mononuclear cells in the peritubular capillaries is observed.

PLATE IX. LEW renal allograft rejected by an IgG-BN recipient (HE, $\times 450$ ). High-power view of the cortico-medullary area shown in Plate VIII. Mononuclear cells resembling monocytes and lymphocytes have marginated in the peritubular capillaries. 


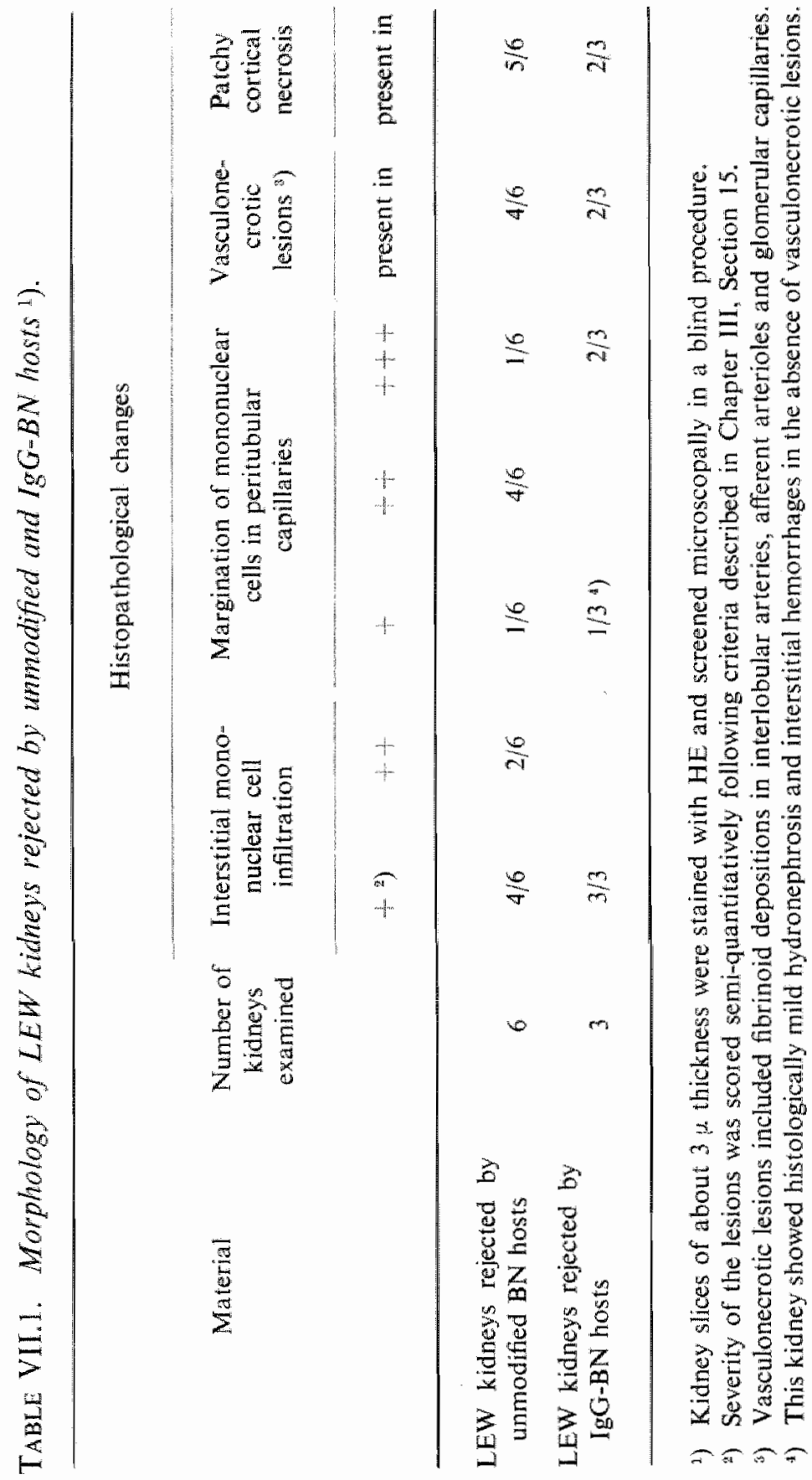




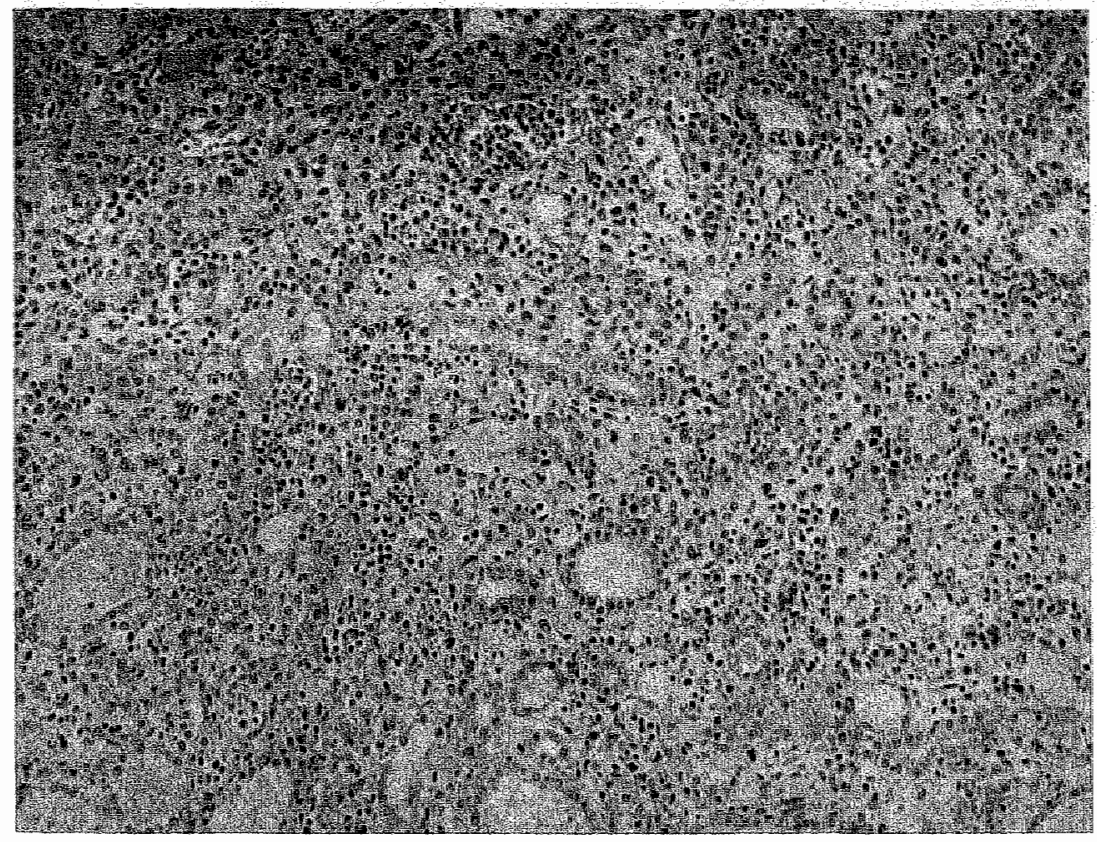

Plate VII. For legend see p. 131.

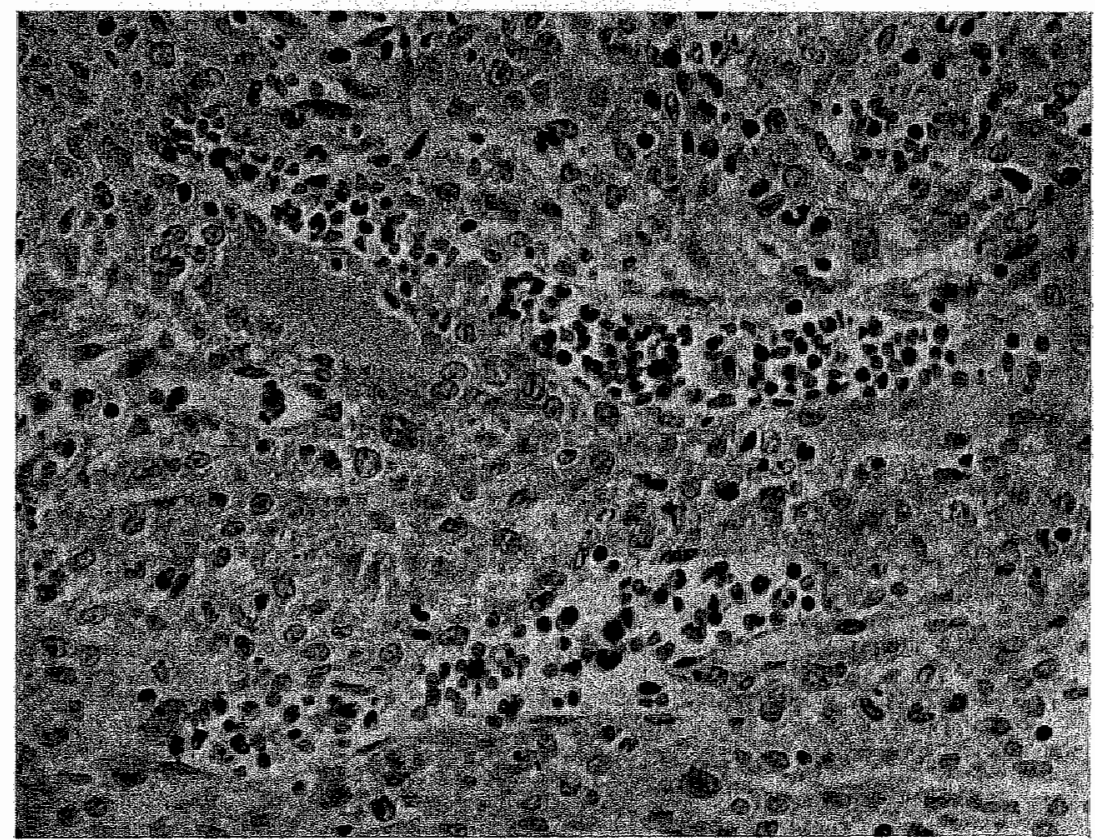

Plate IX. For legend see p. 131. 
comparable to or more pronounced than the margination observed in LEW kidneys rejected by unmodified BN hosts. LEW kidneys rejected by IgG-BN host showed fibrinoid deposits in the afferent arterioles and focal/locally in the glomerular capillaries, particularly in the outer renal cortex in two out of three instances; this was associated with patchy renal cortical necrosis (Plates $\mathrm{X}, \mathrm{XI}$,

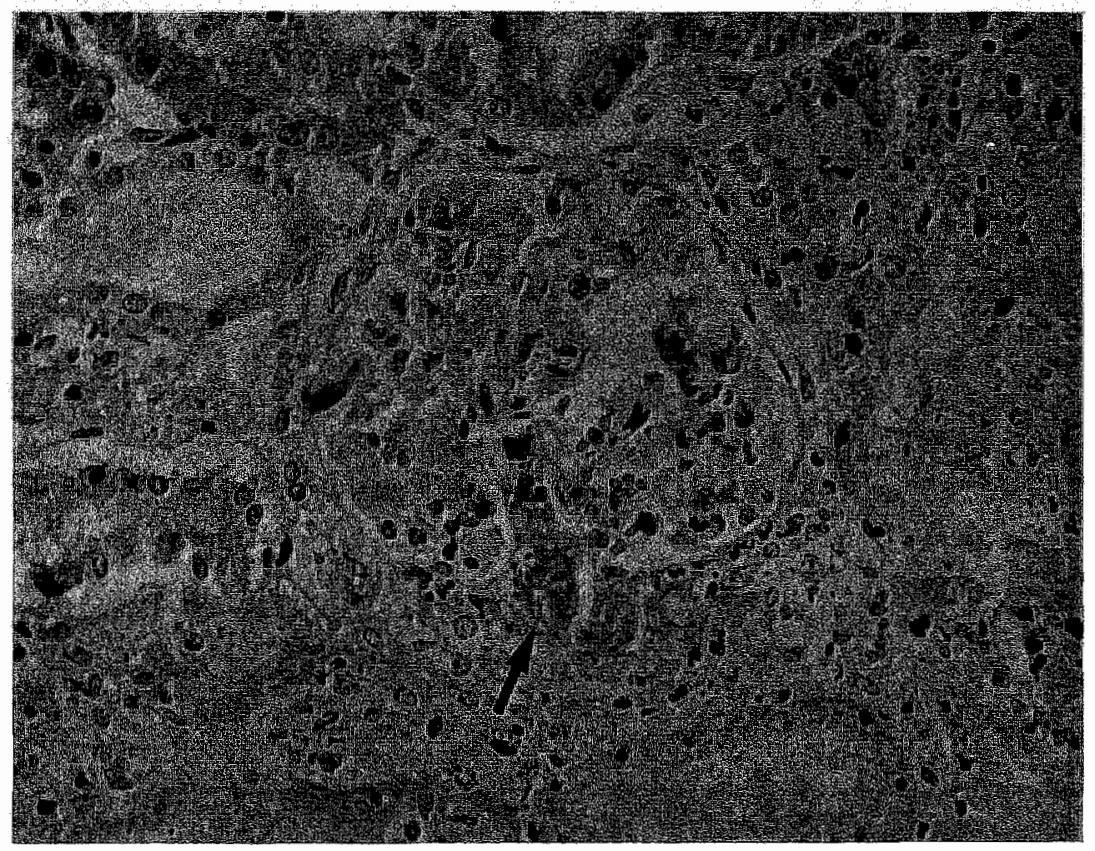

PLATE X. LEW renal allograft rejected by an IgG-BN recipient (HE, $x 400$ ). Fibrinoid deposits are clearly seen in the afferent arteriole $(b)$ and in the glomerular capillaries.

and XII). Similar lesions were also observed in LEW kidneys rejected by unmodified hosts. Fibrinoid necrosis of interlobair arteries was seen in LEW kidneys rejected by unmodified as well as by IgG-BN responders (Plate XIII; Table VII.1). Thus, the vascular lesions observed in LEW kidneys rejected by IgG-BN hosts did not differ from those observed in LEW kidneys rejected by unmodified BN hosts. The interstitial cellular infiltrate in LEW kidneys rejected by unmodified BN recipients however was far more developed compared to the interstitial infiltrate of LEW kidneys rejected by 


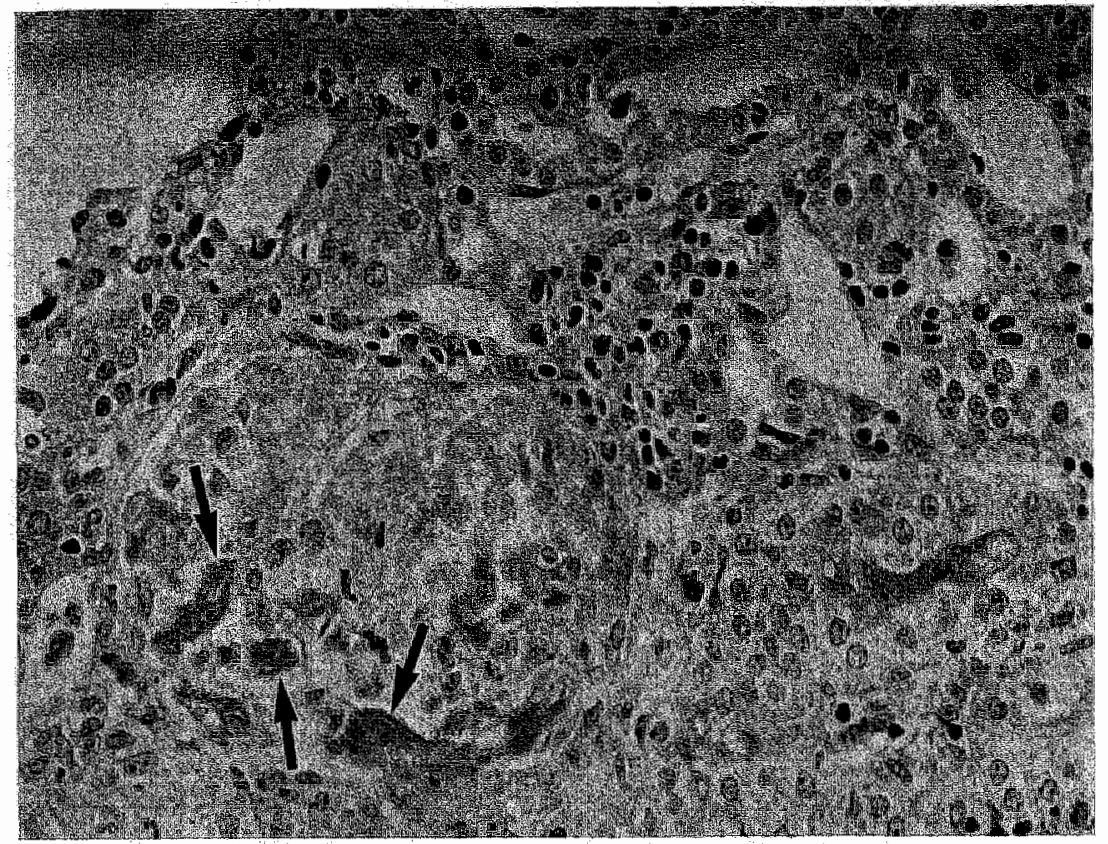

PLATE XI. For legend see p. 136.

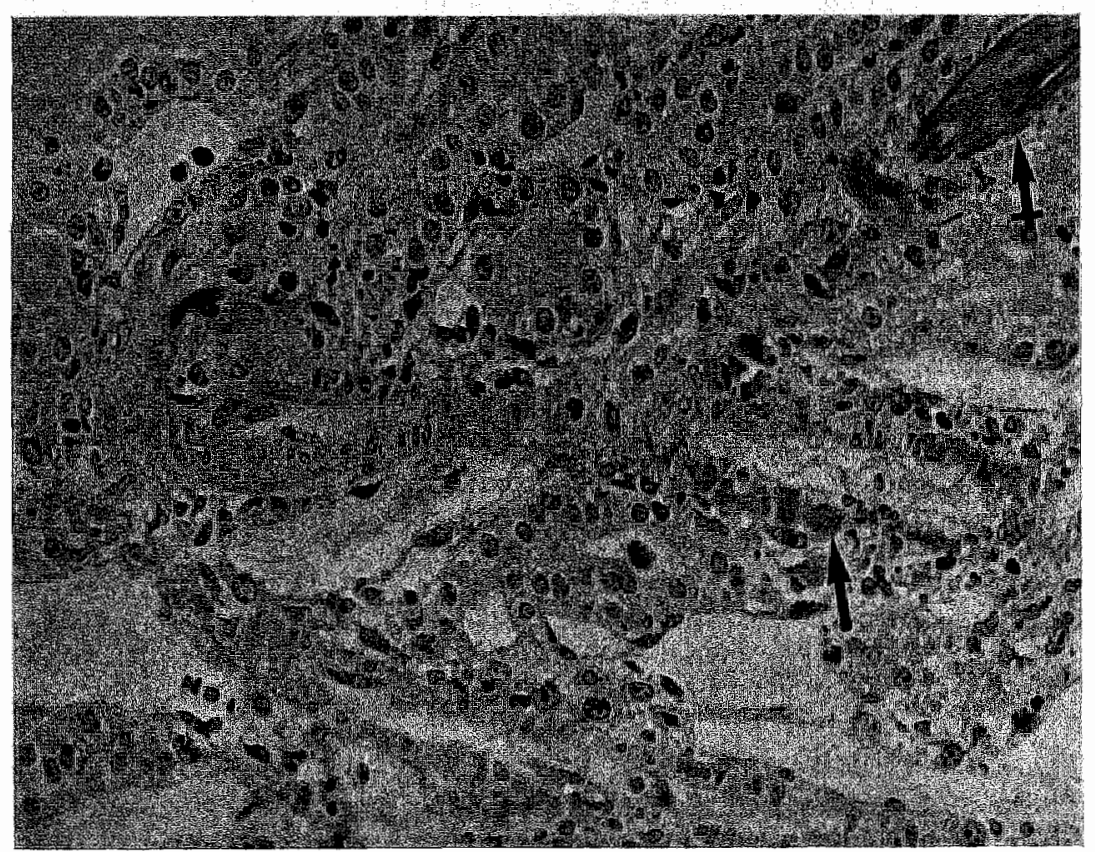

Plate XIII. For legend see p. 136. 


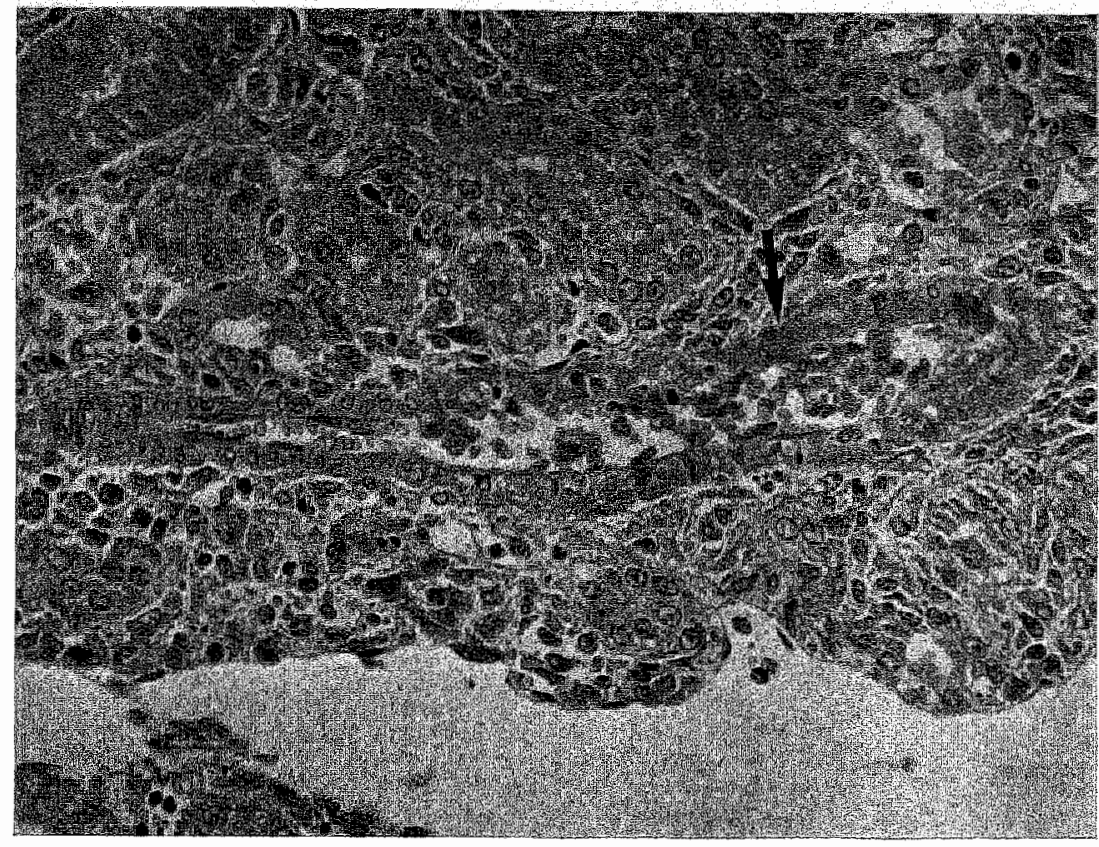

PLATE XIII. LEW renal allograft rejected by an unmodified $B N$ recipient $(\mathrm{HE}, \times 400)$. Fibrinoid deposits are seen in the media of an interlobular artery $(0)$.

$\operatorname{IgG}-\mathrm{BN}$ recipients. The presence of immunoglobulin deposits in LEW kidneys rejected by unmodified $\mathrm{BN}$ as well as $\mathrm{IgG-BN}$ hosts was assessed by indirect immunolluorescence. IgM as well as IgG (Plate XIV) inmunoglobulins were deposited in an interrupted linear pattern along the glomerular capillary walls in LEW kidneys rejected by both types of hosts.

PLATE XI. LEW renal allograft rejected by an IgG-BN recipient (HE, $\times 400$ ). Notice the fibrinoid deposits in the glomerular capillaries $(\downarrow)$.

PLATE XII. LEW renal allograft rejected by an $I g G-B N$ recipient (HE, $\times 400$ ). Fibrinoid deposits are clearly seen in the media of an interlobular artery ( () and in an afferent arteriole $(+)$. 


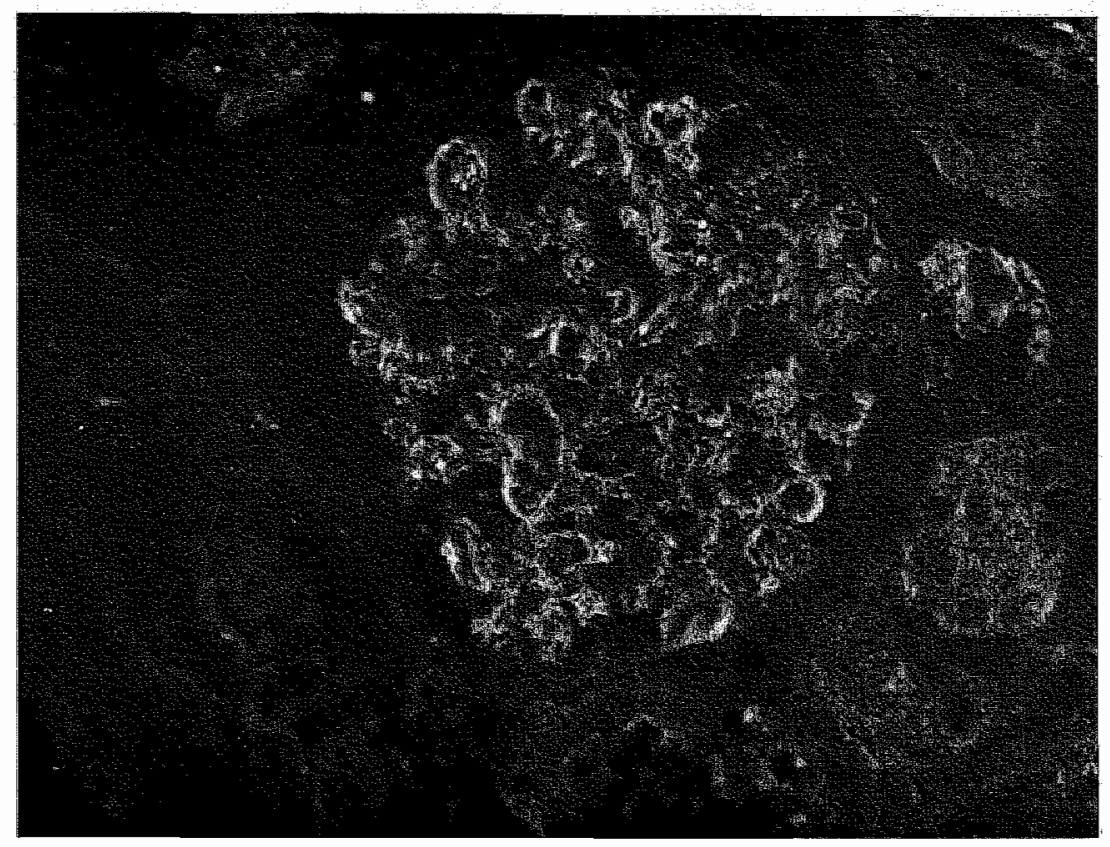

PLATE XIV. LEW renal allograft rejected by an $\operatorname{IgG-BN}$ recipient (Indirect immunofluorescence technique, $\times 500$ ). IgG is deposited alongside the glomerular capillaries in a somewhat interrupted linear-like pattern.

\section{Cytotoxic $T$ cell response of $\operatorname{Ig} G-B N$ rats to $L E W$ renal grafts}

In order to decide by which mechanism(s) $\lg \mathrm{G}-\mathrm{BN}$ recipients rejected their LEW kidneys, spleens were removed from these recipients from the 4 th to 10 th day postoperatively and splenic T lymphocyte-mediated cytotoxicity against LEW thymocyte target cells was measured. T lymphocytes were purified by passage over nylon wool columns; spleens from IgG-BN as well as unmodified BN hosts of LEW renal grafts yielded comparable numbers of splenocytes up to the 9th day post-operatively (Table VII.2). Prior to insertion of LEW kidneys cytotoxic T lymphocytes were not demonstrable in the spleens of IgG-BN rats (Fig. VII.2). In IgG-BN hosts of LEW kidneys cytotoxic $T$ lymphocytes became clearly demonstrable on the 7 th day post-operatively and increased in numbers or efficiency of lysis up to the 9 th day post-transplantation. Compared to splenic $\mathrm{T}$ lymphocyte-mediated cytotoxicity of un- 
TABLE VII.2. Yield of nylon wool non-adherent cells from the spleens of IgG-BN and unmodified BN recipients of $L E W$ kidneys.

\begin{tabular}{|c|c|c|}
\hline \multirow{3}{*}{$\begin{array}{l}\text { Days after } \\
\text { transplantation }\end{array}$} & \multicolumn{2}{|c|}{ Number of cells harvested $\times 10^{-7}($ mean $\pm \mathrm{SD})$} \\
\hline & \multirow[t]{2}{*}{ Un modified $B N$} & \multirow{2}{*}{$\operatorname{Ig} G-B N$} \\
\hline & & \\
\hline 4 & $13.0 \pm 6.3$ & $11.4 \pm 3.2$ \\
\hline 5 & $14.7 \pm 6.1$ & $15.0 \pm 2.9$ \\
\hline 6 & $16.8 \pm 7.5$ & $18.3 \pm 5.5$ \\
\hline 7 & $24.1 \pm 6.8$ & $15.1 \pm 1.1$ \\
\hline 8 & $10.5 \pm 4.8$ & $17.5 \pm 8.7$ \\
\hline 9 & $20.4 \pm 5.1$ & $12.0 \pm 1.1$ \\
\hline 10 & $14.6 \pm 3.4$ & $12.0 \pm 1.4$ \\
\hline
\end{tabular}

modified BN recipients of LEW kidneys the generation of cytotoxic $T$ lymphocytes in IgG-BN recipients of LEW kidneys was clearly delayed by at least two days; thus the magnitude of the splenic $T$ lymphocyte-mediated cytotoxicity at the 5 th day postoperatively in IgG-BN recipients of LEW kidneys was well below $(P<0.005$ at effector to target cell ratio's of $200: 1$ and $100: 1$ ) the $T$ cellmediated cytotoxicity of unmodified BN hosts of LEW kidneys.

\section{Binding of $B N$ ani $L E W-E \lg G$ antibodies to $L E W$ renal grafts}

The results presented above suggested that antibody rather than cytotoxic $\mathrm{T}$ lymphocytes played a prominent role in the rejection of LEW kidneys by $\operatorname{lgG}-\mathrm{BN}$ responders for three reasons. First, rejection was accelerated compared to rejection of LEW kidneys by unmodified BN hosts; second, rejection preceded the appearance of cytotoxic $T$ lymphocytes; and third, the lesions in the graft, specifically the fibrinoid deposits in the vasculature, appeared to be antibody-mediated (1); this assumption is supported by the immuno-fluorescence studies of rejected grafts.

In order to demonstrate that BN anti LEW-E IgG antibodies did bind to LEW kidneys in vivo pair-labeled binding studies were performed in lieu of immunofluorescence studies; this was done 


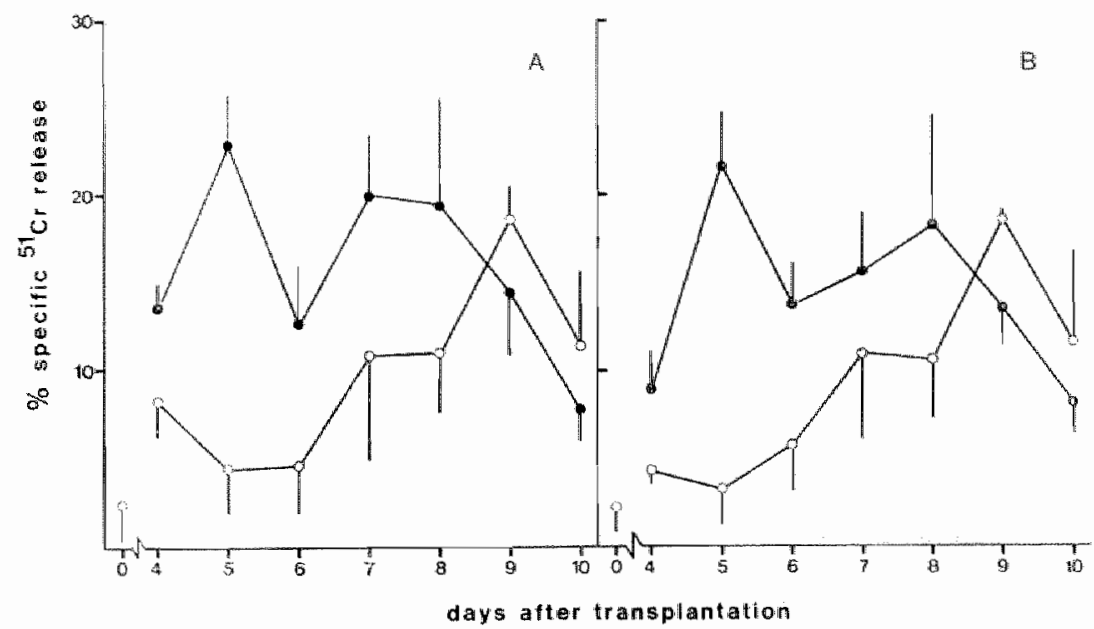

Fig. VII.2. Kinetics of the $T$ cell-mediated cytoroxic response of ummodified and $\operatorname{IgG-BN}$ hosts of LEW kidneys.

Splenic $\mathrm{T}$ lymphocytes were isolated from the spleens of unmodified and IgC-BN $(O)$ hosts of LEW kidneys and assayed for their cytotoxic capacity on "Cr-labeled LEW thymocytes. Panel A, effector : target cell ratio $=100: 1$, panel B, effector: target cell ratio $=200: 1$. Fach point represents the mean cytotoxicity measured in 4 BN hosts of LEW kidneys. Vertical bars represent SEM.

because $\mathrm{Fc}$ receptors within the kidney (19) may aspecifically bind IgG and consequently may cause errors in the interpretation of immunofluorescence studies. For pair-labeled binding studies IgG was isolated from BN anti LEw-E IgG alloantibody containing antiserum and normal BN serum. Pure IgG preparations were obtained when judged by immunoelectrophoresis against rabbit anti rat serum antisera. IgG preparations thus prepared contain mainly $\mathrm{IgG}_{24}$ and $\mathrm{IgG}_{2 \sharp}$ subclasses $(6)$; most of the BN anti LEW-E IgG hemagglutinins were shown to reside in this fraction (7). The radio-labeled IgG preparations were over $90 \%$ precipitable with $20 \%$ trichloroacetic acid and had a specific acitivity of $1 \mu \mathrm{Ci} / \mu \mathrm{kg}$ for ${ }^{131}\left[-\mathrm{lgG}\right.$ and of $5 \mu \mathrm{Ci} / \mu \mathrm{g}$ for ${ }^{125} \mathrm{~J}-\mathrm{IgG}$. In order to determine the percentage of alloantibody within the BN anti LEW-E IgG preparations binding studies with BN and LEW erythrocytes were performed (Table VII.3). In antigen excess $0.13 \%$ of BN anti LEW-E IgG bound specifically to LEW erythrocytes. Next the pair-labeled 
TABLL VII.3. Specific binding of BN anti LEW-E IgG antibody to $L E W-E^{1}$ ).

Incubation Specific uptake $\quad$ per $5 \times 10^{\circ}$

LEW-E in \% of initially added dose

$\begin{array}{ll}\text { first } & 0.09 \\ \text { second } & 0.04 \\ \text { third } & 0.00\end{array}$

i) $117 \mathrm{ng}$ of $125 \mathrm{BN}$ anti LEW-E IgG antibody together with $142 \mathrm{ng}$ of 134 normal BN IgG were added to $5 \times 10^{\circ} \mathrm{BN}-\mathrm{E}$ and $\mathrm{LEW}-\mathrm{E}$ in a total volume of $1.0 \mathrm{ml}$. After $20 \mathrm{~min}$ at $0^{\circ} \mathrm{C}$ the erythrocytes were pelleted and the supernatants were again added to $5 \times 10^{\circ} \mathrm{BN}-\mathrm{E}$ and LEW-E respectively. This procedure was repeated once more.

2) Specific uptake was calculated by subtracting the binding of ${ }^{1: 31} \mathrm{IgG}$ from the binding of ${ }^{126} \mathrm{I}-\mathrm{IgG}$; if specific binding of ${ }^{125} \mathrm{I}-\mathrm{IgG}$ by $\mathrm{BN}$ erythrocytes was observed (up to $0.02 \%$ of the dose) then this was subtracted from the specific binding of ${ }^{12} \mathrm{I}-\mathrm{IgG}$ by LEW-E.

mixture was infused into normal BN recipients of LEW kidneys. Six $\mu \mathrm{g}$ of ${ }^{125}$ I-labeled $\mathrm{BN}$ anti LEW IgG preparation was infused which is about $8 \mathrm{ng}$ of specific antibody and probably less than the binding capacity of one kidney. Up to $0.09 \%$ of the infused 185I BN anti LEW-E IgG bound specifically to the LEW graft after 6 to 24 hours (Table VII.4). This is less than the $0.13 \%$ binding observed in in vitro binding studies but not in contradiction with conditions of relative antigen excess since alloantibody bound to the endothelial antigens show a much reduced half-life $(8)$. All specific binding to the LEW renal graft could be removed by prior absorption of the paired labeled mixture with LEW erythrocytes added in calculated antigen excess.

\section{Alloantibody response of $\operatorname{Ig} G-B N$ rats to $L E W$ renal grafis}

Although BN anti LEW-E IgG antibodies were shown to be capable of binding to LEW renal grafts and are also capable of activating homologous complement $(18,38)$ they did not cause hyperacute rejection of LEW renall allografts. Consequently, if IgG antibody 
TABLE VII.4. In vivo binding of $B N$ anti $L E W-E$ antibody to $L E W$ renal grafts in $B N$ rats $^{1}$ ).

\begin{tabular}{cccc}
\hline $\begin{array}{c}\text { Time of sacrifice } \\
\text { after transplantation } \\
\text { (hours) }\end{array}$ & $\begin{array}{c}\text { Absorption with } \\
\text { LEW-E prior to } \\
\text { infusion }\end{array}$ & $\begin{array}{c}\text { Specific uptake by one } \\
\text { kidney in \% of infused } \\
\text { dose }\end{array}$ \\
& LEW graft & BN kidney \\
\hline 6 & - & 0.09 & 0.01 \\
24 & + & 0.00 & 0.00 \\
& - & 0.07 & 0.00 \\
\hline
\end{tabular}

1) Mixtures of ${ }^{125}$-labeled BN anti LEW-E IgG antibodies and 13x-mabeled non-immune $B N$ IgG were infused into $B N$ recipients of $L E W$ renal grafts; one BN kidney was left untouched. When desired the paired labeled nixture was absorbed with LEW-E in antigen excess. The number of LEW-E needed was determined by means of in vitro binding studies (Table VII. 3).

were to mediate the accelerated rejection of LEW renal allografts in IgG-BN recipients 'help' has to be recruted. Conceptually, the help may be additional (IgG) antibody against the same or another specificity since the density of IgG molecules on a target cell has been shown in vitro to influence complement fixation (28). Alternatively, 'help' may be provided by specifically activated and aspecific effector cells of ADCC that might become more efficient by high density coating of target cells with IgG antibody $(20,26,33)$. Therefore, the kinetics of anti LEW-E hemagglutinin responses as well as the magnitude of cytotoxic antibody responses were measured in $\mathrm{IgG}-\mathrm{BN}$ recipients of LEW renal grafts. Anti LEW-E IgG hemagglutinin titers decreased in all IgG-BN recipients of LEW renal grafts within 48 hours after transplantation and increased thereafter in 6 out of $7 \mathrm{IgG}-\mathrm{BN}$ hosts (Fig. VIT.3). BN anti LEW-E IgG hemagglutinins decreased also in IgG-BN recipients of syngeneic BN kidneys although less compared to the decrease observed after insertion of a LEW kidney (Table VII.5). 
TABLE VII.5. Effect of insertion of LEW and BN kidney grafts on the hemagglutinin titers in $\lg G-B N$ hosts ${ }^{1}$ ).

\begin{tabular}{lcrrrrr}
\hline $\begin{array}{l}\text { Kidney donor } \\
\text { strain }\end{array}$ & $\begin{array}{c}\text { Hours of } \\
\text { residence }\end{array}$ & $\begin{array}{c}\text { Titer prior to } \\
\text { transplantation }\end{array}$ & $\begin{array}{c}\text { Titer at termination } \\
\text { of the experiment }\end{array}$ \\
& & & & & & \\
IgM ${ }^{2}$ ) & IgG ${ }^{3}$ ) & IgM & IgG \\
LEW & 4 & 2 & 8 & 0 & 2 \\
LEW & 12 & 0 & 32 & 0 & 16 \\
LEW & 12 & 0 & 64 & 0 & 16 \\
LEW & 24 & 0 & 32 & 0 & 16 \\
LEW & 24 & 4 & 64 & 0 & 8 \\
LEW & 48 & 2 & 16 & 0 & 8 \\
LEW & 48 & 2 & 32 & 0 & 4 \\
BN & 48 & 0 & 8 & 0 & 4 \\
BN & 48 & 0 & 8 & 0 & 4 \\
\hline
\end{tabular}

1) LEW and $B N$ kidneys were inserted into $\operatorname{IgG-BN}$ recipients in which $\operatorname{IgM}$ and $\operatorname{IgG}$ hemagglutinins were determined just prior to and at $4,12,24$, or 48 hours after transplantation.

a) IgM hemagglutinin titers were determined by the direct hemagglutination assay.

$\left.{ }^{3}\right)$ IgG hemagglutinin titers were determined by the indirect hemagglutination assay.

After about the 4th day post-operatively $\operatorname{lgM}$ hemagglutinins were also demonstrable in IgG-BN recipients of LEw kidneys (Fig. VII.3). Alloantibody-dependent complement-mediated cytotoxicity assays confirmed and extended the results quoted above. Cytotoxic antibodies to donor antigens were measured from three unmodified $\mathrm{BN}$ and 4 IgG-BN recipients of LEW kidneys on the 6th day post-operatively. This day was choosen since LEW kidneys were rejected by IgG-BN hosts in about 6 days. Whole antisera were assayed for cytotoxicity to LEW lymph node cells before and after removal of antibody to Class I antigens by absorption with LEW-E. Both guinea pig and rat serum were used as sources of complement (Cf. Chapter VI, Section 6). 


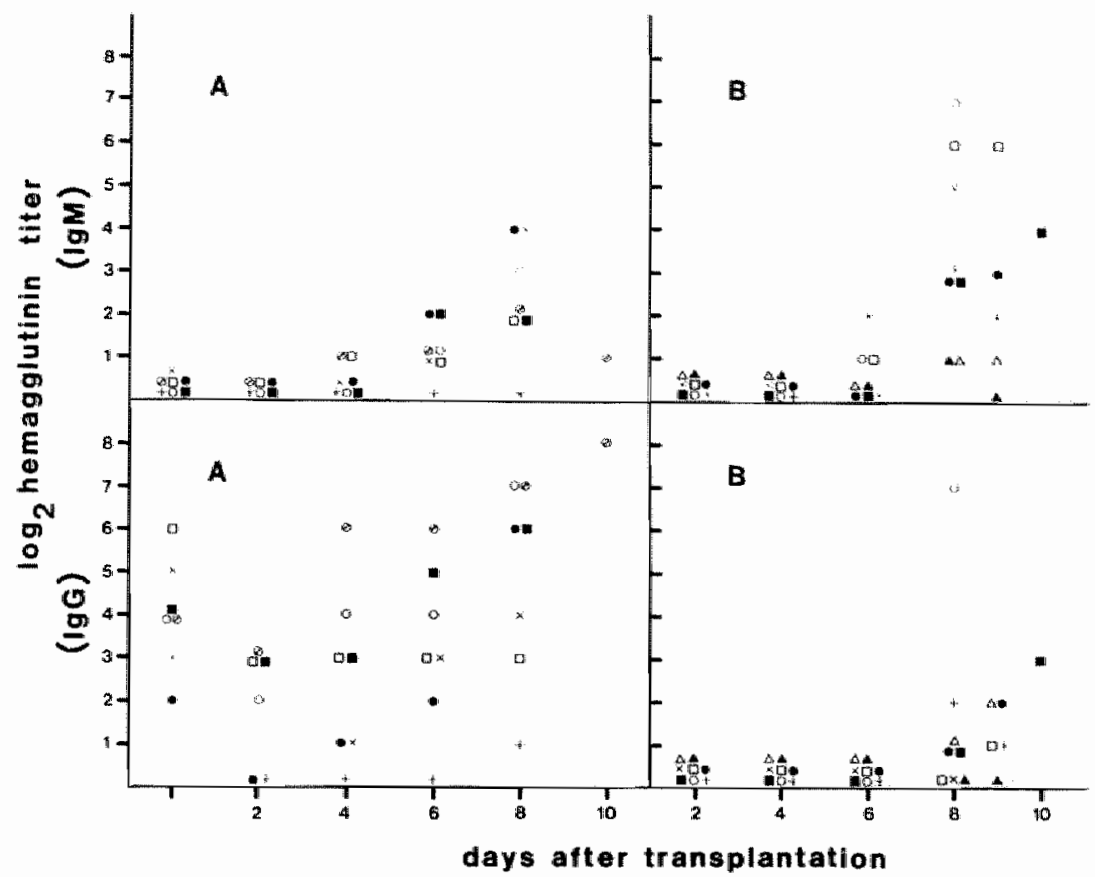

FIG. VII.3. Kinetics of anti LEW-E hemagglutinin production in unmodified and IgG-BN hosts of LEW kidneys.

Anti LEW IgM hemagglutinins (upper panels) and IgG hemagglutinins (lower panels) were monitored in sera from $\operatorname{lgG}-\mathrm{BN}$ (A) and unmodified BN (B) hosts of LEW kidneys. Identical symbols in upper and lower panels refer to one serum sample.

Whole sera from both groups of BN recipients of LEW kidneys were equally cytotoxic to LEW target cells when tested in the presence of guinea pig serum; cytoxicity of the BN anti LEW kidney sera from both groups of $\mathrm{BN}$ recipients was reduced to the same extent after absorption with LEW-E (Fig. VII.4, bottom panels). In the presence of rat complement cytotoxicity of sera obtained from IgG-BN hosts of LEW renal grafts exceeded somewhat the cytotoxicity observed in sera from unmodified BN hosts of LEW kidneys (Fig. VII.4A, top); the cytotoxic capacity of both groups of alloantisera in the presence of rat complement was almost eliminated after absorption with LEW-E (Fig. VII.4B, top). These results show that alloantisera harvested on the $6 \mathrm{th}$ post-operative day 


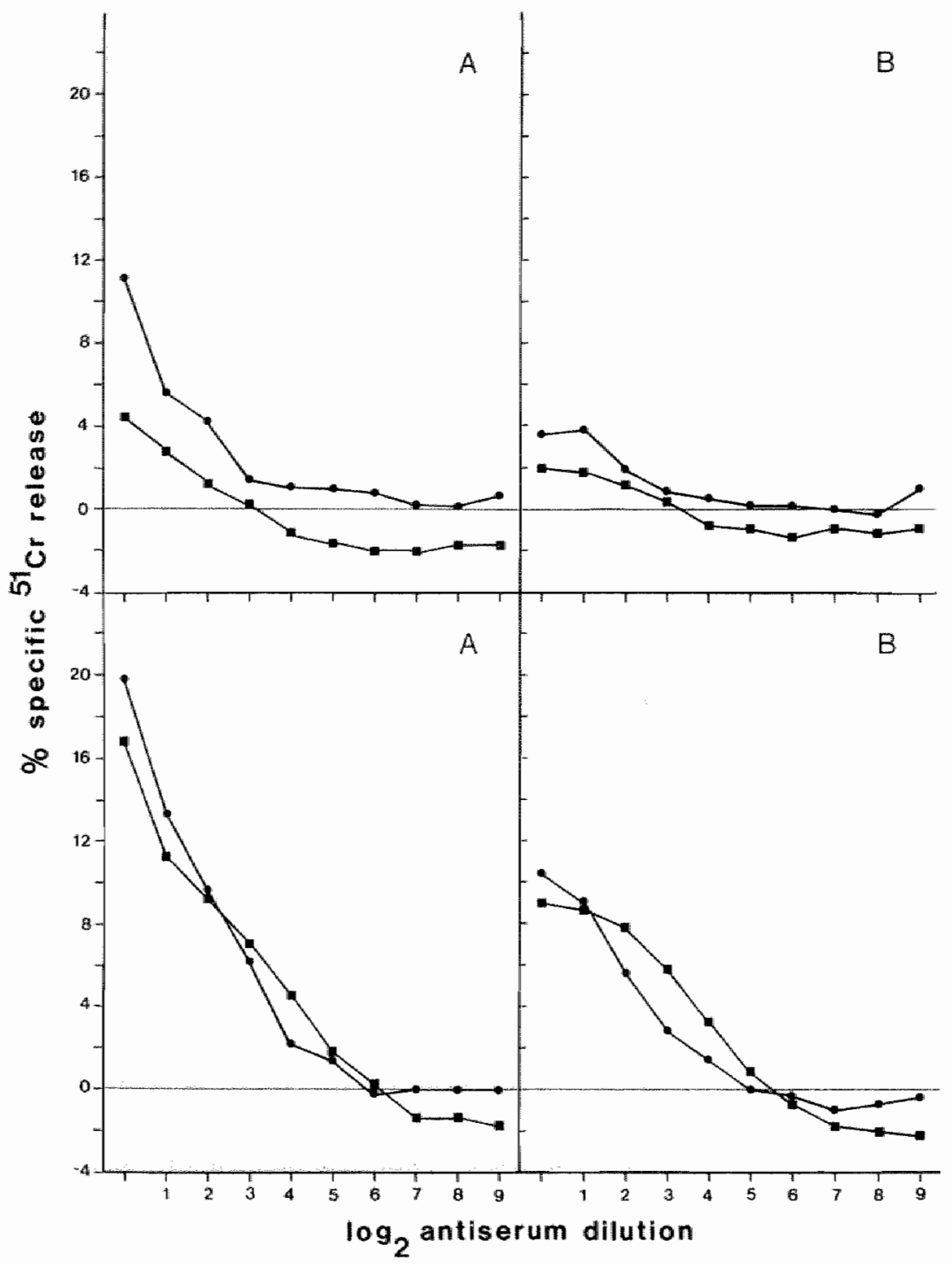

FIG. VII.4. Cytotoxic antibodies in sera obtained from unmodified and $\operatorname{Ig} G-B N$ hosts of LEW kidneys.

Sera obtained from three unmodified ( $\square$ ) and $4 \mathrm{IgG}-\mathrm{BN}$ hosts (-) of LEW kidneys at 6 days after transplantation were assayed for cytotoxic antibodies on "iCr-labeled LEW lymph node cells. Upper panels, in the presence of rat complement; lower panels, in the presence of guinea pig complement. A, neat antisera; $B$, antisera after absorption with LEW-E. 
from IgG-BN rats differed somewhat from the alloantisera harvested from unmodified BN hosts of LEW kidneys since IgG-BN recipients of LEW kidneys possessed more cytotoxic IgG antibodies directed to donor Class I antigens compared to unmodified BN recipients of LEW kidneys. Antibodies to donor Class II antigens were present in sera derived from both groups of recipients since the sera were cytotoxic to LEW target cells after removal of Class II alloantibodies and probably of the IgM class for the cytotoxicity was for the major part xenogeneic complement-dependent.

\section{Discussion}

The main results from this study are twofold : 1) LEW kidneys transplanted to IgG-BN recipients were neither 'enhanced' nor destroyed hyperacutely but were rejected in a slightly accelerated fashion compared to controls; and 2) Accelerated rejection occurred in spite of the fact that $T$ lymphocyte-mediated cytotoxicity was markedly decreased.

It is well established that passive transfer of hyperimmune anti donor antisera at the time of surgery may cause enhanced or reduced survival of organ allografts (12); the effect observed depends on the species and strain combination selected, on the organ or tissue transplanted, and on antibody specificity and affinity as well as on the immunoglobulin class in which these antibodies reside. In inbred rats hyperimmune alloantisera - raised by immunizing recipient strain rats repeatedly with donor lymphoid cells with or without donor-type skin grafts - have been shown to enhance the survival of renal allografts in $\mathrm{F}_{1}$ to parent $(17,30,40)$ or fully allogeneic donor-recipient combinations (3I). The antibodies effective in these models of passive enhancement were taken to be of the IgG class since the sera they resided in were obtained by hyperimmunization. In addition, early studies have shown that IgG fractions obtained from hyperimmune antisera to donor antigens caused enhancement of allografts but the IgM fractions from these hyperimmune sera were associated with accelerated rejection when passively transferred to the recipients (32). With regard to the subclass of the $\operatorname{IgG}$ antibodies capable of inducing passive enhancement, $\operatorname{IgG}_{1}$ antibodies were initially thought to be superior to $\mathrm{IgG}_{2}$ antibodies in a tumor allograft system, 
suggesting the inability of $\lg G_{1}$ antibodies to activate complement and thus to give enhancement by covering the antigens of the graft (43). The same group of investigators subsequently showed that $\operatorname{IgG}_{2 \mathrm{~A}}$ antibodies were also capable to enhance tumour growth provided that only small quantities of $\operatorname{IgG}_{2 A}$ antibodies were passively transferred. Thus, depending on the quantity of $\operatorname{lgG}_{2 A}$ antibodies administered to the recipient enhanced and stunted tumour growth could be obtained in this model (16). Similar observations were reported for rat renal allografts : passive transfer of $\operatorname{IgG}_{2 \mathrm{~A}}$ antibodies isolated from hyperimmune anti donor serum induced progressively more prolonged graft survival as the strength of the histocompatibility barrier crossed (and thus the MHC antigen density in the graft) decreased (32). It has now been demonstrated that $\operatorname{IgG}$ antibodies present in one population could not be separated in an enhancing and a cytotoxic moiety when separated by physico-chemical methods (24). Thus, it appears that enhancing antibodies reside predominantly in the $\operatorname{lgG}$ class but expression of the enhancing properties appears to be determined by the antigen density in the target organ and by the antibody-to-antigen ratio.

These findings are in agreement with and predicted by a model of Linscotr developed on the basis of an in vitro model (28). Using a hapten (arsinilic acid) coupled to the surface of erythrocytes and anti arsenilate antibodies he showed that the antigen density on the target cells determined whether or not complement-fixing $\mathrm{lgG}$ antibodies mediated lysis of the target cells in the presence of complement. When the $\operatorname{lgG}$ antibodies were prevented from forming closely associated doublets because of a low antigen density on target cells or because an insufficient amount of antibody was added to target cells having a high antigen density then no target cell lysis occurred.

When the results from the study of LinsCotT (28) are used to explain the different effects of IgG antibodies on graft survival, then specificity of the antibodies can be predicted to play an important role as well because the density of donor antigens (e.g. Class I and Class (I antigens) may vary for each donor strain and for each organ used for transplantation. In the rat, enhancement of heart and kidney allografts was shown to be mediated mainly, if not exclusively by antibodies to Class II antigens $(14,39)$. Since 
Class Il antigens probably play an important role in sensitizing the recipient to the graft (4) enhancement may be suggested to be brought about by binding of antibodies to donor Class II antigens expressed on 'passenger' leukocytes (23), on 'allogeneic effect. factor' (3) and on the endothelial cells of the graft (34). However, simple masking of donor Class II antigens could not mediate enhancement since $F(a b)_{2}$ fragments of enhancing antibodies were ineffective in this respect $(6,46)$.

There is also evidence that $\operatorname{lgG}$ antibodies to donor Class 1 antigens residing in hyperimmune alloantisera may enhance allografts. In the mouse a slight but statistically significant prolongation of skin allograft survival has been observed by infusing small amounts of IgG antibodies to donor Class I antigens - obtained by acid elution of antibodies absorbed onto highly purified donor erythrocytes - at the time of skin grafting and in the early postoperative period (44). Preliminary reports suggest that passive transfer of antibodies to donor Class I antigens may also enhance rat renal (25) and mouse cardiac (15) allografts.

The finding that the $\mathrm{Fc}$ fragment of anti donor $\operatorname{lgG}$ antibody is needed for induction of enhancement together with the observation that (allo-)antigen-reactive cells are capable of binding immune complexes led to the hypothesis that donor-specific antigenreactive cells may be eliminated after opsonization by binding of donor antigen complexed with (IgG) antibody $(22,23)$. According to this model antibodies to donor Class II antigens can be predicted to enhance more efficiently than antibodies to donor Class I antigens without excluding an (additional) role for the latter (4).

Since BN rats were immunized in such a fashion as to produce IgG antibody to LEW Class I antigens prior to insertion of a LEW kidney and secondary antibody responses readily developed in these recipients, opsonization of antigen-reactive cells was clearly not applicable to our model. Thus, direct interaction of Class I antigens expressed on the endothelial cells of the Lliw graft and anti LEW-E IgGr antibodies is more likely to be operative in our model than opsonization of antigen-reactive cells. The model of LinscotT (28) and results obtained by others (2l) predict that LEW kidneys inserted into $\mathrm{IgG}$-BN recipients would be rejected hyperacutely or in an accelerated fashion for three reasons. First, the physico-chemical characteristics of the antibodies showed 
them to reside in the $\operatorname{lgG}_{2}$ subclass; antibodies residing in this subclass fix homologous complement well $(18,38)$. Second, LEW donors and $\mathrm{BN}$ recipients differed over the full $\mathrm{MHC}$ barrier including loci coding for Class I antigens, thus presumably providing a high density of Class I antigens in the graft. Third, as monitored by hemagglutination assays on sera from IgG-BN hosts of LEW kidneys, anti LEW-E IgG antibodies were in antibody excess except for the second day after transplantation.

In contrast to the prediction outlined above LEW kidneys were not rejected hyperacutely by IgG-BN hosts. Hyperacute rejection was not prevented by interference of early postoperative azotemia with inflammatory reactions (5) for LEW renal grafts inserted into unilaterally nephrectomized IgG-BN recipients showed no histological signs of hyperacute rejection when removed at one or two days after transplantation (Data not shown).

Both LEW kidneys rejected by unmodified $\mathrm{BN}$ and by IgG-BN recipients showed histologically vasculonecrotic lesions in the arteries, the afferent arterioles, and the glomeruli. It is unlikely that these lesions were caused by cytotoxic $\mathrm{T}$ lymphocytes since their generation was severely depressed in IgG-BN hosts at the time of onset of LEW renal graft rejection. Depression of cellular immunity may have been caused by suppressor cells acting on delayed-type hypersensitivity reactions and generated in the course of a humoral immune response to LEW Class I antigens $(36,37)$. Anti donor antibodies of the $\mathrm{IgM}$ class were unlikely to be involved either in the induction of vasculonecrotic lesions since these antibodies failed to cause such lesions in LEW kidneys grafted into IgM-BN recipients (Chapter VI). Therefore, our data as well as those of others $(I, 40)$ suggest vasculonecrotic lesions in the graft to be caused by $\operatorname{lgG}$ antibodies. The failure of $\mathrm{IgG}$ antibodies to donor Class I antigens to induce vasculitis in the graft in the immediate post-operative period may be explained in two fashions which are not mutually exclusive.

First, the quantity of BN anti LEW-E IgG available for binding to the graft in the early post-operative period maly have been insufficient to create the number of IgG doublets necessary to activate complement. Delivery of antibody to the graft could be hampered by the diminished renal flow in the early period after transplantation as reflected by the transient post-operative azotemia 
in the recipient. This argument may hold particularly for the peritubular capillaries since clearance of ${ }^{131}$ I-labeled hippuran was shown to be severely curtailed during the first three days after transplantation (42). It is less likely to be a valid argument for the smaller interlobular arteries and afferent arterioles that are well perfused even in acute vasomotor nephropathy (13). The fact however that the vasculonecrotic lesions were only encountered in the outer renal cortex - a region known to be exquisitely sensitive to ischaemia to which it responds more rigorously by decreasing blood flow than the inner cortex $(10)$-- suggests that the hypothesis outlined above cannot be dismissed readily. Consequently, accelerated rejection of LEw kidneys may be explained to result from improvement of renal flow on the 4th day after transplantation together with increasing serum titers for anti LEW-E IgG hemagglutinins, creating the conditions necessary to bring about IgG antibody-mediated vasculonecrotic injury.

According to the second explanation the density of Class II antigens in the graft is supposed to be too low to induce vasculitis even in the presence of excess IgG antibodies to these antigens. Density of antibody coating of the graft endothelium may be enhanced by antibodies to additional specificities e.g. donor Class II and monocyte-associated antigens (29). However, since antibody to Class II antigens was shown to be predominantly of the $\operatorname{lgM}$ class these antibodies are not likely to have contributed to improved activation of complement on the surface of donor-type target cells $(9,38)$. Alternatively, these antibodies may act in conjunction with IgG antibodies to donor Class I antigens in order to increase the susceptibility of the graft for ADCC reactions $(2,27,45)$. Antibodies to specificities other than donor Class I and Class II antigens have not been determined in this study. Assuming them to exist and to be of the $\operatorname{IgG}$ class already at 5 days after transplantation these antibodies may have cooperated with IgG antibodies to donor Class I antigens in complement activation.

Both explanations for the accelerated rejection of LEW kidneys by $\operatorname{IgG}$-BN hosts rely on the continuous presence of $\operatorname{lgG}$ antibodies to donor Class $I$ antigens in antibody excess in these recipients. Anti LEW-E IgG antibody titers had decreased two days after insertion of LEW kidneys into $\mathrm{JgG}-\mathrm{BN}$ recipients but were restored within two to 4 days and finally even exceeded the titer present prior to transplantation in 4 out of 7 instances. This strong response 
may reflect activation of antigen-specific memory cells or may be due to the presence of a Lew graft in these rats acting as an in vivo immunoadsorbent. $\lg G$ antibodies may exert a negative feed-back on their own production as well as on the production of $1 \mathrm{gM}$ antibodies to the same specificity (4l). Transient elimination of this feed-back by binding of $\lg G$ antibodies to the graft may explain both the secondary $\operatorname{IgM}$ and increased $\operatorname{IgG}$ responses to $L E W-E$ associated antigens observed after transplantation of LEW kidneys to $\operatorname{lgG}-\mathrm{BN}$ recipients.

\section{Summary}

LEW renal allograits grafted into $\operatorname{lgG}-B N$ recipients were rejected in a slightly accelerated fashion when compared with controls. Also the onset of rejection was observed earlier in $\operatorname{lgG}$-BN hosts of LEW kidneys; together with the vasculonecrotic lesions observed histologically in rejected kidneys $\operatorname{IgG}$ antibodies to donor Class I antigens present during residence of the LEW kidneys in IgG-BN recipients were considered most likely to have brought about curtailed renal allograft survival.

In spite of the presence of IgG antibodies to donor Class I antigens at the time of insertion of LEW kidneys into IgG-BN responders hyperacute rejection or enhanced survival of these grafts was not observed. Failure to observe immunological enhancement of LEW kidneys residing in $\operatorname{IgG}-\mathrm{BN}$ hosts was supposed to be due to the sensitized state of the host for donor Class I antigens preventing opsonization of non-sensitized antigen-reactive host lymphocytes to occur.

Although antibodies to donor Class 1 antigens in $\mathrm{IgC}-\mathrm{BN}$ rats were complement-fixing LEW kidneys were not rejected hyperacutely by these rats. "This finding suggested that "help" was needed in conjunction with the IgGr antibodies in order to reject LEW renal allogratis in an accelerated fashion. 'Help' was not likely to be provided by cytotoxic T lymphocytes since cell-mediated cytotoxic responses were markedly suppressed up to the time of renal allograft rejection. Alternatively, 'help' may have been provided by improvement of renal flow a few days post-operatively. Increase of renal flow may enhance opsonization of somatic cells in the graft which in turn facilitates the injurious attack by complement and ADCC effector cells. 


\section{References}

1 Abbas, A. K., Corson, J. M., Carplenter, C. B., Calwanek, E. G., MERRIEL., J. P., and DAMMIN, G. J. : Immunological enhancement of rat renal allografts. I. Comparative morphology of acutely rejecting and passively enhanced grafts. Am. J. Pathol. $75: 255,1974$.

2 Andersson, B., Skoglund, A.-C, and Rosen, A.: Functional characterization of mouse $\mathrm{T}$ lymphocytes with $\operatorname{IgM}-\mathrm{Fc}$ receptors. I. Siludies on ADCC and helper cell function. $J$. Immunol. $123: 1936,1979$.

3 Armerding, D., Sachs, D. H., and Katz, D. H. : Activation of T and B lymphocytes in vitro. III. Presence of la determinants on allogeneic effect factor (AEF), J. Exp. Med. 140: $1717,1974$.

4 Bach, F. H., BACH, M. L., and Sondel, P. M. : Differential function of major histocompatibility complex antigens in T-lymphocyte activation. Nature 259: 273, 1976.

5 BALCH, H. H. : The effect of severe battle injury and posttraumatic renal failure on resistance to infection. Am. Surg. $142: 145,1975$.

6 Bloch, K. J., Morse, H. C. IlI, and Austen, F. K. : Biological properties of rat antibodies. I. Antigen binding by four classes of anti DNP antibodies. J. Immunol. 101: 650, 1968.

7 BREDA VRIesman, P. J. C. VAN: Personal communication.

8 Breda VRIESman, P. J. C. VAN, and Feldman, J. D. : YM alloantibody elicited by first set renal allografts: in vivo and in vitro studies. J. Immunol. 108 : 1188, 1972.

9 Breda Vriesman, P. J. C. van, Swanen-Sierag, L., and Vlek, L. F. M. : Cytotoxic and enhancing properties of early $\gamma M$ alloantibodies elicited by first set renal allografts. Transplantation 20:385, 1975.

10 CANNON, P. J.: The kidney in heart failure. Now. Eng. I. Med. 296: $26,1977$.

11 Capel, P. J. A., Tamboer, W. P. M., WaAl, R. M. W. de, Jansen, J. L. J., and KOENE, R. A. P.: Passive enhancement of mouse skin allografts by antibody is $\mathrm{FC}$ dependent. Transplantation $/ 22: 421,1979$.

12 CARpenter, C. B., D'ApICE, A. J. F., and Abras, A. K. : The role of antibodies in the rejection and enhancement of organ allografts. Adv. Immunol. $21: 1,1976$.

13 CONGER, D. W., and SCHRIER, R. W. : Renal hemodynamics in acute renal failure. Ann. Rev. Phys. 42: 603, 1980.

14 DAvies, D. A. L., and ATHENs, B. J. : What abrogates heart transplant rejection in immunological enhancement? Nature $247: 294,1974$.

15 Davis, W. C. : Enhancement of heart allograft survival across the H-2 complex. Transplant. Proc. 9: 937, 1977. 
16 Duc, H. T., KinskY, R. G., and Vorsin, G. A. : Ia vs. K/D antigens in immunological enhancement of tumour allografts. Transplantation 25 : $182,1978$.

17 FABrE, J. W., and Morkis, P. J.: Passive enhancement of rat renal allograft with only partial cover of the incompatible AgB specificities. Transplantation 18: 429, 1974.

18 Füst, G., Medgyesi, G. A., BaziN, H., and Gergely, J. : Differences in the ability of rat IgG subclasses to consume complement in homologous and heterologous serum. Immunol. Letters I: 249, 1980.

19 Grlfand, M. C., Frank M. M., Green, 1 , and Skin, M. L. : Binding sites for immune complexes containing $\operatorname{lgG}$ in the renal interstitium. Clin. Immunol. Immunopathol. 13: 19, 1979.

20 Ghebrehiwit, B., Medicus, R. G., and Müller-Eberhard, H. J. : Potentiation of antibody-dependent cell-mediated cytotoxicity by target cell bound C $3^{\mathrm{b}} . J$. Immunol. $123: 1285,1979$.

21 Gutrman, R. D., Forbes, R. D. C., Cramer, D. V., and Gill, T. J. III : Cardiac allograft rejection and enhancement in natural recombinant rat strains. Transplantation 30:216, 1980.

22 Hutchinson, I. V., and ZOLA, H. : Antigen-reactive cell opsonization (ARCO). A mechanism of immunological enhancement. Transplantation $23: 464,1977$.

23 Hutchinson, I. V., and ZOLA, H. : Opsonic activity of "anti la" like enhancing antisera. Transplantation 23: 513, 1977.

24 Janssen, J. L. J., Koene, R. A. P., Kamp, G. J. V., GerlaG, P. G. G., and Wudeveld, P. G. A. B. : Enhancement and hyperacute rejection of skin graft in the mouse. Failure to separate cytotoxic from enhancing antibodies from alloantiserum with physico-chemical methods. J. Immunol. 1/4: 1557, 1974.

25 Jeekel, J, DONGeN, J VAN, Majoor, G., and Harder, F. : Enhancement of rat renal allograft with antibodies directed against erythrocyteassociated alloantigens. Transplant. Proc. 9: 969, 1977.

26 Keany, M., MCPhiall, S., Jodouin, C.-A., and Richter, M. : The antibody-dependent cell-mediated cytotoxic reaction. II : The effect of the concentration of anti-target cell antibodies on the identity of the human eflector cells. Immunoiogy $40: 205,1980$.

27 Lamon, E. W., Shaw, M. W., Goodson, S., Lidin, B., Walia, A. S., and Fuson, E. W. : Antibody-dependent cell-mediated cytotoxicity in the Moloney sarcoma virus system : differential activity of $\mathrm{IgG}$ and IgM with different subpopulations of lymphocytes. J. Exp. Med. 145 : $302,1977$.

28 Linscorr, W. D. : Effect of cell surface antigen density on immunological enhancement. Nature 228: 824, 1970. 
29 Moraes, J. R., and Stastny, P. : A new antigen system expessed in human endothelial cells. J. Clin. Inv. $60: 449,1977$.

30 Morris, R., and LUCAS, Z. J. : Immunological enhancement of rat kidney grafts : evidence for peripheral action of homologous antiserum. Transplant. Proc. 3 : 697, 1971.

31 Mullen, Y., and Hildemann, W. H. : Kidney tramsplantation genetics and enhancement in rats. Transplant. Proc. $3: 669,1971$.

32 MUllen, Y., Raisin, R, and Huldemand, W. : Cytotoxic versus immunom blocking effects of specific alloantibodies. Transplantation $24: 99,1977$.

33 Northof, H., KLUGE, A., and ResCH, K. : Antibody-dependent cellular cytotoxicity (ADCC) against human erythrocytes, mediated by blood group alloantibodies : a model for the role of antigen density in target cell lysis. Z. Immun. -Forsch. 154: 15, 1978.

34 Paul, L. C., Milford, E. L., Paradysz, J. M., and Carpenter, C. P. : Alloantigens on the endothelium of rat kidneys. Transplant. Proc. : in press.

35 Perlmann, P., Perlmann, H., and Wigzell, H. : Lymphocyte mediated cytotoxicity in vitro. Induction and inhibition by humoral antibody and the nature of the effector cells. Transplant. Rev. 13: 91, 1972.

36 Ramshaw, I. A., Bretscher, P. A., and Parish, C. R. : Regulation of the immune response. I. Suppression of delayed type hypersensitivity by $\mathrm{T}$ cells from mice expressing humoral immunity. Eur. J. Immunol. 6 : $674,1976$.

37 Ramshaw, I. A., Bretscher, P. A., and Parish, C. R. : Regulation of the inmune response. II. Repressor $\mathrm{T}$ cells in cyclophosphamideinduced tolerant mice. Eur. J. Immunol. $7: 180,1977$.

38 Ruskiewicz, M. : Complement activating properties of some rat alloantibodies. Tramsplantation 20:227, 1975.

39 Soullilou, J. P., Carpenter, C. B., d'Apice, A. J. F., and Strom, T. B. : The role of nonclassical, $F$ c receptor associated $\mathrm{AgB}$ antigens (Ia) in rat allograft enhancement. J. Exp. Med. 143: 405, 1976.

40 Strom, T. B., Carpenter, C. B. Girovoy, M. R. Abbas, A. K., Corson, J. M., and Soullilou, J. P. : Modification of the rat alloimmune response by enhancing antibodies and the role of blocking factors in the survival of renal grafts. Transplantation $20: 368,1975$.

41 UHR, J. W., and MöLler, G. : Regulatory effect of antibody on the immune response. Adv. Immunol. $8: 81,1968$.

42 Vlek, L. F. M., and Breda VRtesman, P. J. C. Van : Personal communication.

43 Volsin, G. A., KINSKY, R., JANSEN, F., and BerNARD, C.: Biological 
properties of antibody classes in transplantation immune sera. Transplantarion $8: 618,1969$.

44 WAL, R. M. W. DE, CAPEL, P. J. A., and KOENE, R. A. P. : The role of ant $H-2 K$ and $H-2 D$ alloantibodies in enhancement and acute allo-

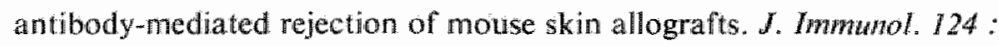
$719,1.980$.

45 WALKER, W. S. : Mediation of macrophage cytolytic and phagocytic activity by antibodies of different classes and class specific Fc receptors. J. Immunol. 119: 367, 1977.

46 Winearls, C. G., Fabre, II. W., Millard, P. R., and Morris, P. J. : A quantitative comparison of whole antibody and $F(a b)_{2}$ in kidney allograft enhancement. Transplantation 28: 36, 1979. 


\section{THE EFFECT OF HUMORAL UNRESPONSIVENESS TO LEW-E ON THE REJECTION OF LEW RENAL GRAFTS BY BN RATS}

\section{Introduction}

Studies presented in this thesis as well as by others (19) indicated that neither hyperacute rejection nor marked enhancement of rat renal allograft survival can be obtained by introducing antibodies directed to donor Class I antigens prior to transplantation. On the other hand, particularly $\operatorname{IgG}$ antibodies to donor antigens have been shown to contribute to acute renal allograft rejection (l). To assess the importance of the contribution of antibody responses to LEW Class I antigens in the rejection of LEW kidneys by BN rats LEW kidneys were grafted into $\mathrm{BN}$ rats made unresponsive to LEW-Eassociated antigens by infusion of large amounts of LEW-E.

\section{Experimental protocol}

As shown in Chapter IV, unresponsiveness of BN rats to LEW-E could be reproducibly induced by infusion of $1 \times 10^{10} \mathrm{LEW}-\mathrm{E}$ in one month old recipients. However, since $\mathbb{L E W}-\mathrm{E}$ unr. BN rats of 1.5 month of age were too small to be used as recipients of renal allografts, unresponsiveness was maintained by one or two further infusions of $1 \times 10^{10} \mathrm{LEW}-\mathrm{E}$ administered at two-week intervals. LEW kidneys were inserted between 12-16 days after the last infusion of LEW-E.

\section{Anti LEW immune responses in LEW-E unt. BN rats}

LEW-E unr. BN rats were screened at 14 days after the last infusion of $1 \times 10^{10}$ LEW-E for anti LEW cytotoxic $T$ cells and antibodies. In serum from BN rats infused with LEW-E neither hemagglutinating antibodies nor antibodies cytotoxic for LEW lymph node cells could be detected. T lymphocytes isolated from the spleens of 


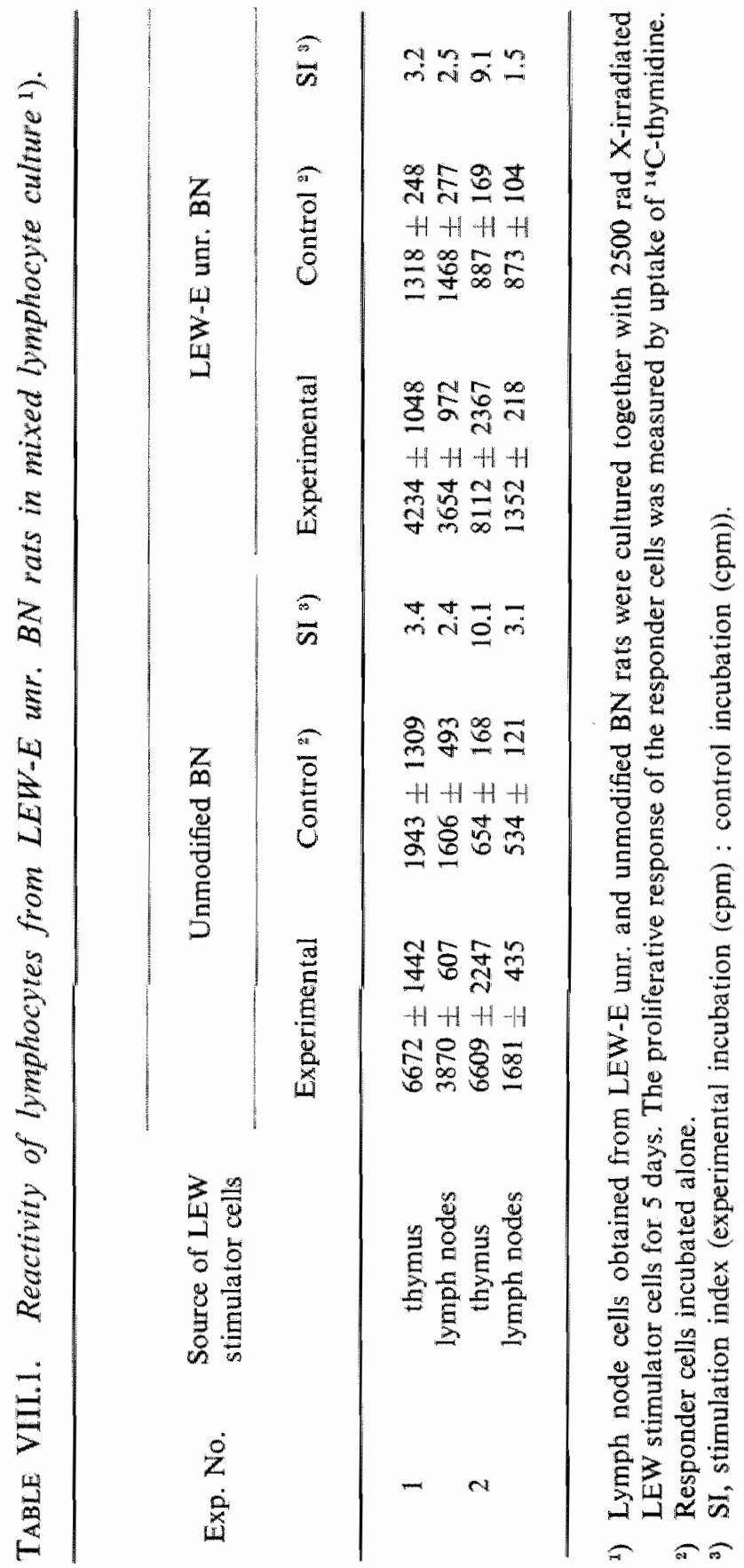


LEW-E unr. BN rats did not effect specific ${ }^{51} \mathrm{Cr}$ release from PHAstimulated LEW lymphoblasts.

In order to determine whether infusions of LEW-E into BN rats affected the cellular responsiveness of these recipients against LEW antigens, lymphocytes from LEW-E unr. BN rats were tested in oneway mixed lymphocyte cultures for their proliferative capacity against LEW thymocytes and lymph node cells. The proliferative response of lymphocytes obtained from $\mathrm{BN}$ rats at 14 days after the third infusion of $1 \times 10^{10}$ LEW-E was identical to that of controls (Table VIII.I).

4 Survival of LEW and WISTAR renal allografts in LEW-E unr. $B N$ hosts

LEW kidneys inserted into BN rats at 12-16 days after the second or third infusion of $1 \times 10^{10} \mathrm{LEW}-\mathrm{E}$ enjoyed a markedly prolonged survival as compared to LEW kidneys grafted into unmodified BN rats. Enhancement of graft survival was specific for LEW kidneys since WISTAR kidneys grafted into LEW-E unr. BN recipients were acutely rejected (Table VIII.2).

Renal function of LEW kidneys residing in LEW-E unr. BN recipients did not differ from controls as judged by the host serum urea concentration up to the 6th day post-transplantation after which controls rejected their grafts in an acute fashion. Although function of LEW renal grafts residing in LEW-E unr. BN recipients usually deteriorated between the 10th and 21 st day after transplantation 13 out of 16 grafts survived this rejection episode; 11 renal grafts had stable function thereafter up to the 50 th post-operative day (Fig. VIII.1).

5 Alloantibody responses of $L E W-E$ unr. BN rats to $L E W$ renal grafts

Both LEW kidneys grafted into unmodified $\mathrm{BN}$ rats and WISTAR kidneys inserted into LEW-E unr. BN recipients elicited hemagglutinins. In contrast, anti LEW hemagglutinins were not detected in serum samples from LEW-E unr. BN recipients of LEW kidneys obtained over the entire post-operative period (Table VIII.2). In order to exclude that small amounts of hemagglutinating anti- 


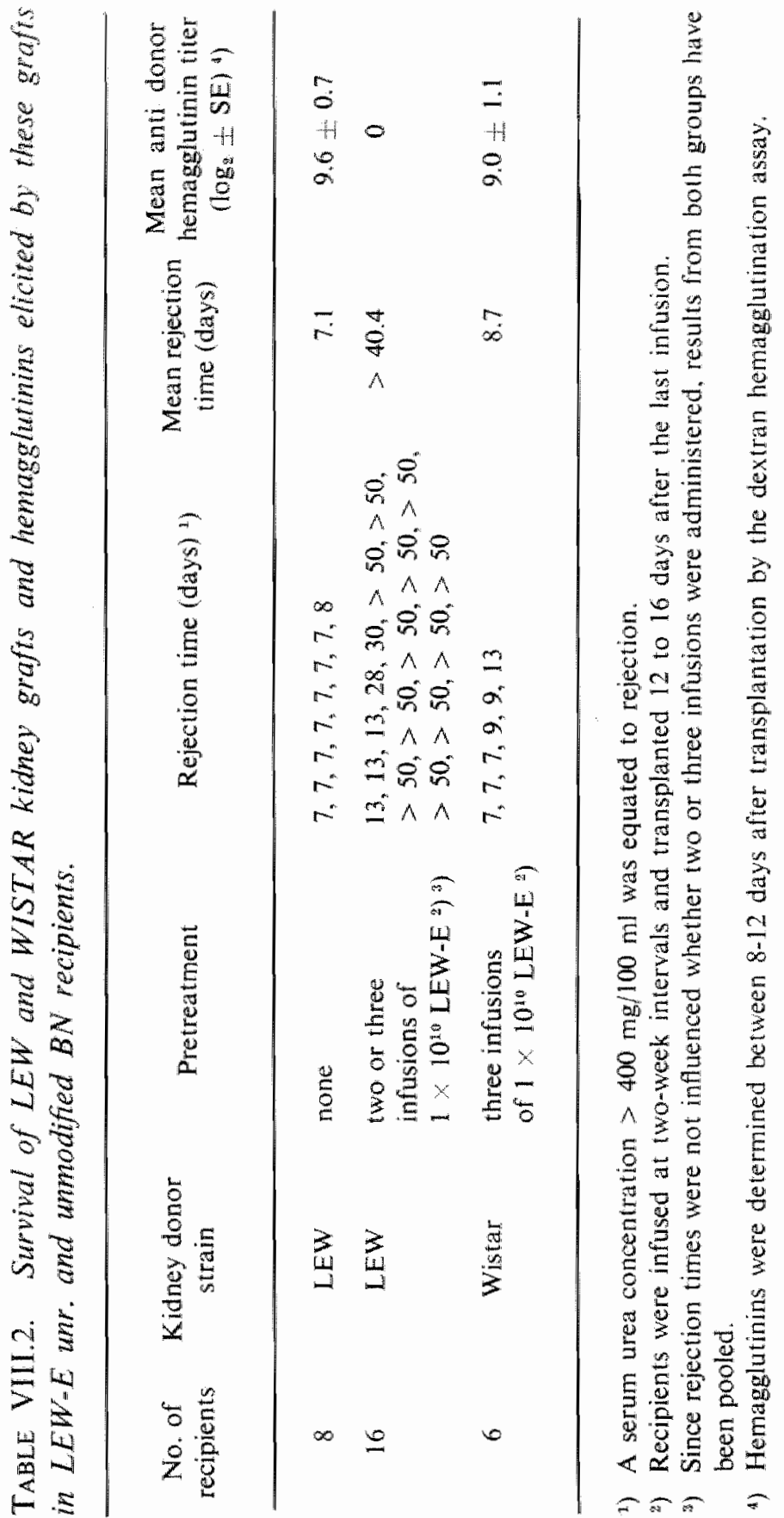




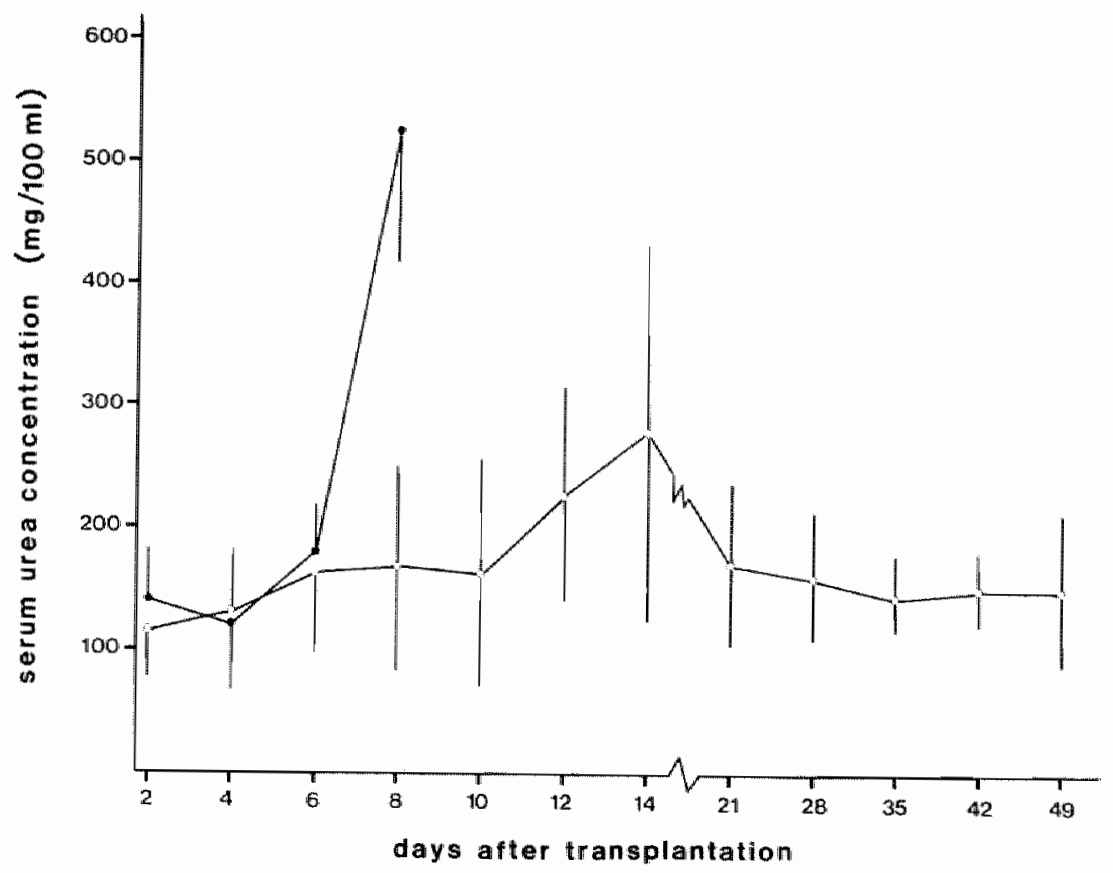

FIG. VIII.1. Serum urea concentrations of unmodified and $L E W-E$ unr. BN hosts of LEW kidneys.

Mean serum urea concentrations are presented of unmodified (๑) and LEW-E unr. (O) BN hosts of LEW kidneys. Vertical bars represent SD. The rejection times of the kidneys are presented in Table VIII.2.

body produced by LEW-E unr. BN recipients of LEW renal grafts were not detected in the serum because they had been absorbed by the graft LEW kidneys were removed from LEW-E unr. and unmodified $\mathrm{BN}$ recipients on the 5 th and 7 th day after transplantation and examined for the presence of $\lg M$ and $\lg G$ antibodies by means of indirect immunofluorescence. IgM antibody deposits were faintly demonstrable on day 5 and clearly seen on day 7 post-transplantation in the glomeruli of control kidneys but not clearly detectable in LEW kidneys removed from LEW-E Unr. BN recipients. IgG antibodies were only detected in the glomeruli of LEW grafts residing in unmodified $B N$ hosts on day 7 after transplantation. 


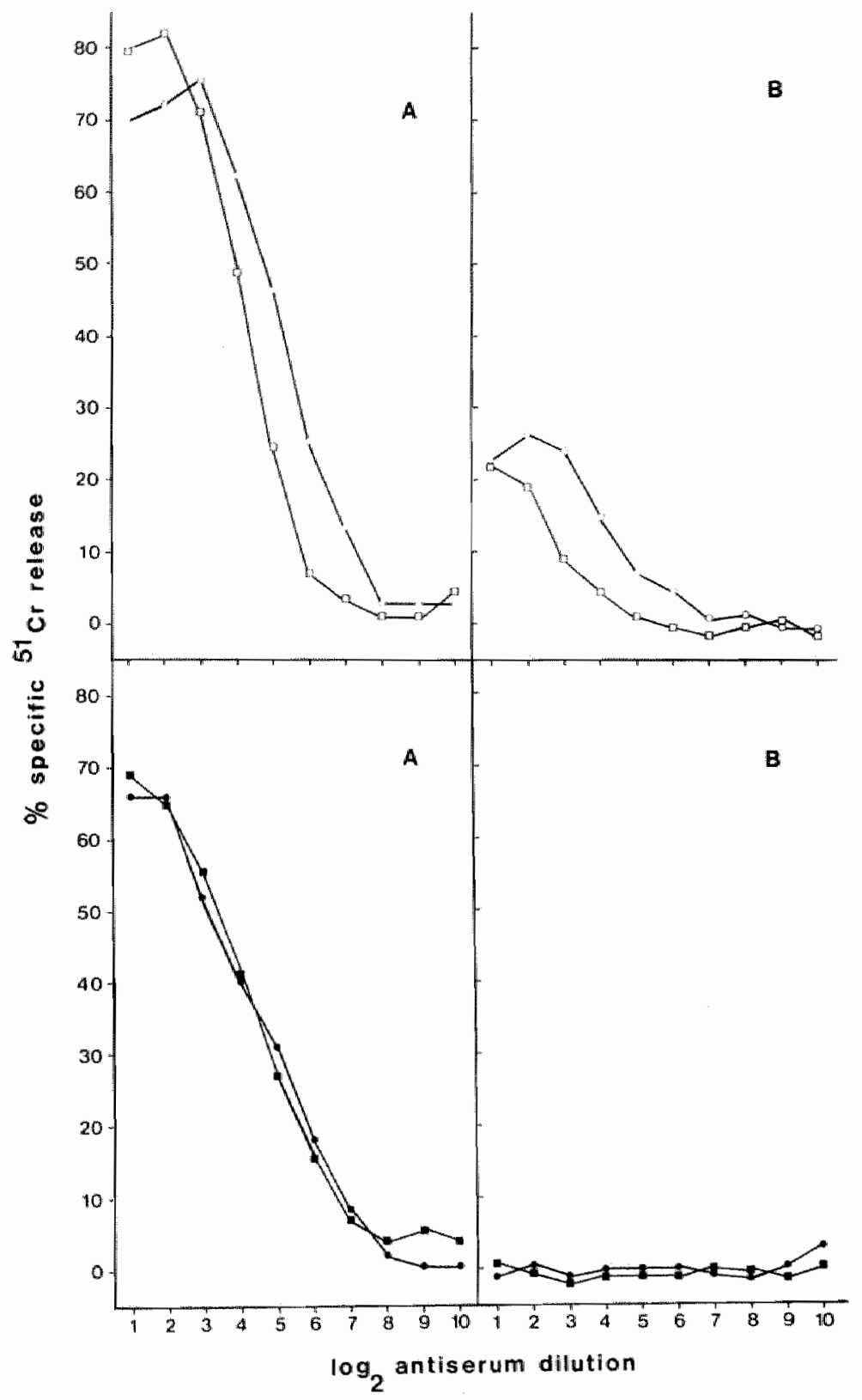




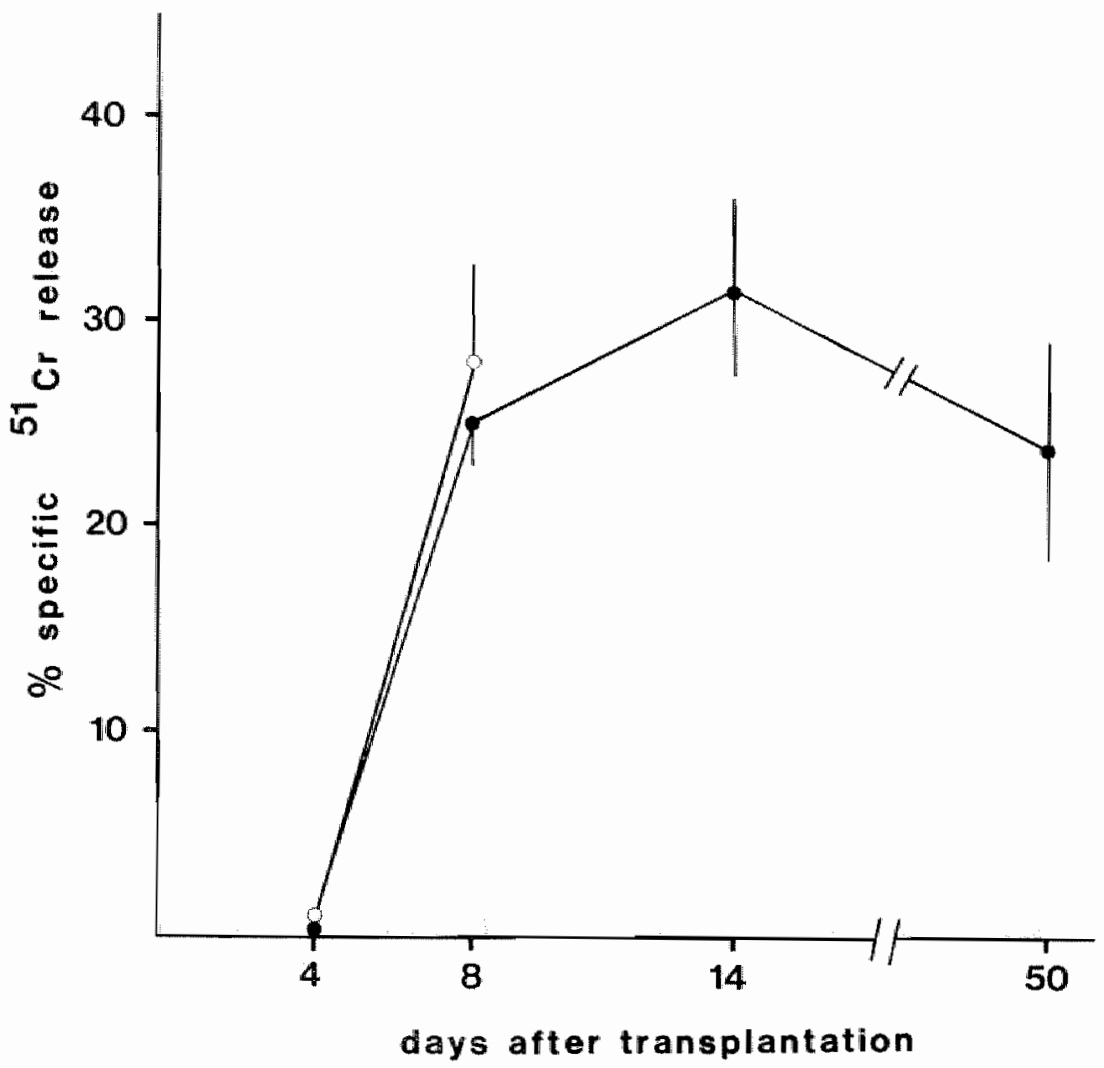

Fig. VIII.3. Kinetics of cytotoxic antibody production in LEW-E unr. BN hosts of LEW kidneys.

Sera obtained from 8 unmodified (O) and 8 LEW-E unr. (1) BN hosts of LEW kidneys were assayed for guinea pig complement-dependent cytotoxic antibodies on ${ }^{51} \mathrm{Cr}$-labeled LEW Iymph node cells. Vertical bars represent SD.

FIG. VIII.2. Cyrotoxic antibodies in sera obtained from unmodified and LEW-E unr. BN hosts of LEW kidneys.

Serum obtained from an unmodified (upper panels) and a LEW-E unr. (lower panels) BN host of a LEW kidney were assayed for guinea pig conplement-dependent cytotoxic antibodies on "Cr-labeled LPS-stimulated lymphoblasts (A) and PHA-stimulated lymphoblasts (B). , O, Neat antisera; 2. 0 , antisera after absorption with LEW-E. 
Lymphocytotoxic alloantibodies were measured in sera from LEW-E unr. BN recipients of LEW kidneys in order to establish that humoral unresponsiveness was restricted to LEW-E-associated alloantigens only. The cytotoxic capacity of these sera was compared to that of sera from unmodified BN recipients of LEW kidneys after absorption of the latter sera with LEw-E. Absorptions with LEW-E reduced the cytotoxic capacity of sera from unmodified, but not of LEW-E unr. BN recipients (Fig. VIII.2). Antibodies cytotoxic for LEW lymph node cells were demonstrable in sera from both groups of recipients at the 8th day post-transplantation and remained present in sera from hosts with surviving grafts up to the time of sacrifice at 50 days after transplantation (Fig. VIII.3).

In order to establish if antibodies elicited by LEW grafts in BN recipients were directed to la-like antigens sera from these recipients were also tested in the antibody-dependent cytotoxicity assay using PHA- and LPS-stimulated lymphoblasts as target cells. In the mouse Ia antigens have been shown to be present on LPS-stimulated lymphoblasts but to be absent from PHA-stimulated lymphoblasts (14). As shown in Fig. VIII.2, cytotoxic antibodies raised by LEW kidneys in LEW-E unr. BN hosts lysed LPS-stimulated lymphoblasts but could not damage PHA-stimulated lymphoblasts, indicating these antibodies to be directed against LEW Class II antigens only.

\section{Cellular inmune responses of $L E W-E$ unr. BN rats to $L E W$ renal grafts}

To decide whether or not the enhanced survival of LEW kidneys grafted into LEW-E unr. BN recipients was due to decreased cellular immunity the cellular response of unmodified and LEW-E unr. BN recipients against LEW kidneys was compared both in vitro and in vivo. Cellular immune responses were studied on day 5 after transplantation since this day was just prior to the onset of acute rejection of LEW kidneys by unmodified BN recipients. Since early post-operative uremia may influence cellular immune responses (I7) kidney graft recipients to be used for studies on cellular immunity were only unilaterally nephrectomized.

In vitro, cell-mediated cytotoxicity of splenic $T$ lymphocytes for LEW Con-A and PHA-stimulated lymphoblasts was measured. 
Splenic effector $\mathrm{T}$ cells obtained from unmodified as well as LEW-E unr. $\mathbb{B N}$ recipients of LEW kidneys lysed a comparable percentage of both types of LEW target cells (Fig. VIII.4). In vivo, cellular immune responses were compared by studying the histology of 6 LEW renal grafts removed from unmodified and 6 grafts removed from LEW-E unr. BN hosts at the 5th day post-transplantation. No differences in histology between LEW kidneys removed from recipients from both groups could be observed qualitatively or semi-quantitatively.

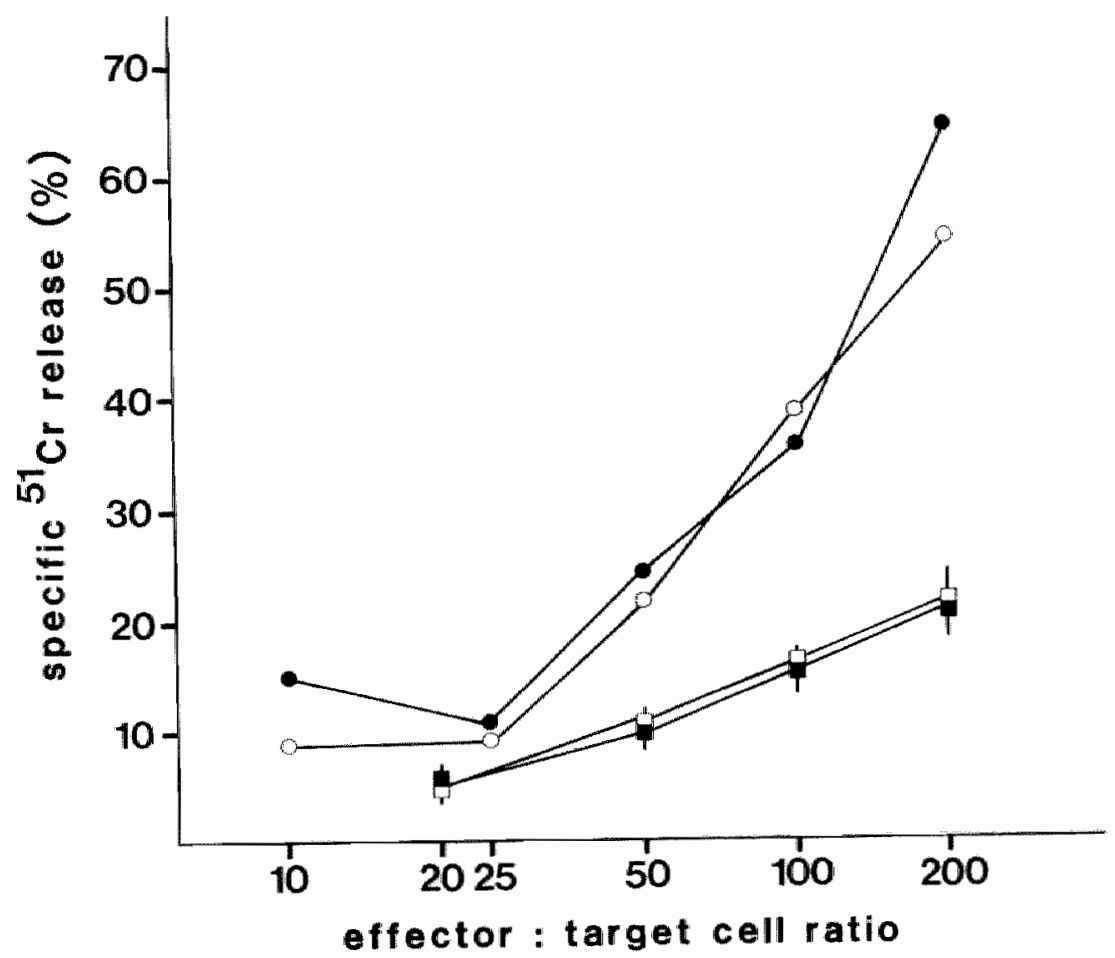

FIG. VIII.4. Cytotoxic capacity of splenic $T$ cells from unmodified and $L E W-E$ unr. BN hosts of LEW kidneys.

$T$ lymphocytes were isolated from the spleens of unmodified and LEW-E unr. BN hosts of LEW kidneys at 5 days post-transplantation and assayed for their cytotoxic capacity on " $\mathrm{Cr}$-labeled PHA- (circles) and Con-A(squares) stimulated lymphoblasts. $O, \square$, unmodified BN hosts of LEW kidneys; $\bullet$, LEW-E unr. BN hosts of LEW kidneys. Vertical bars represent SEM. 
7 Induction of acute rejection of a $L E W$ kidney residing in a $L E W-E$ unr. BN rat

Results obtained thus far in this study favored an important role for antibody to LEW Class 1 antigens in the rejection of LEW kidneys by BN rats. Formal proof for an obligatory contribution of antibody to Class I antigens to graft rejection should include an experiment showing that passive administration of antibody to Class I antigens would induce rejection of a LEw kidney otherwise expected to enjoy prolonged survival.

For the execution of a preliminary experiment serum was obtained from two unmodified BN recipients of LEW kidneys at 8 days after transplantation. A crude $\gamma$-globulin preparation was produced by $\left(\mathrm{NH}_{4}\right)_{2} \mathrm{SO}_{4}$ precipitation as described as the first step in the purification of rat $\mathrm{lgG}$. The precipitate was dissolved in PBS and dialysed against PBS; the final solution had a volume of $5.5 \mathrm{ml}$ and contained $28.1 \mathrm{mg}$ protein/ml. Hemagglutinin titers of this preparation were 512 for $\operatorname{IgM}$ and 8 for IgG.

Commencing at the 5th day after transplantation aliquots of $1.0 \mathrm{ml}$ of the BN anti LEW kidney $\gamma$-globulin preparation were slowly infused at approximately 6-hour intervals into a LEW-E unr. BN host of a LEW kidney. After the third infusion of BN anti LEW kidney antibodies the serum urea concentration of the recipient rose steeply and exceeded $400 \mathrm{mg} / 100 \mathrm{ml}$ on day 7 after transplantation. In a separate experiment, administration of $658 \mathrm{mg} \gamma$-globulins (prepared in the same fashion from serum of unmodified $B N$ rats) over a 43-hour period to a LEW-E unr. BN host of a LEW kidney was shown not to effect a significant rise in serum urea concentration in the recipient (Fig. VIII.5). Thus, administration of $B N$ anti LEW kidney antibody to LEW-E unr. BN rats is tentatively concluded to abrogate the acceptance of LEW kidneys by these recipients.

\section{Discussion}

This study addressed itself to the observation that LEW kidneys transplanted into LEW-E unr. BN rats failed to elicit hemagglutinating alloantibody and enjoyed a markedly prolonged survival. The repeated infusions of LEW-E did not suppress the immune responsiveness of the recipients non-specifically (12) as indicated by three observations. First, lymphocytes taken from LEW-E-infused 


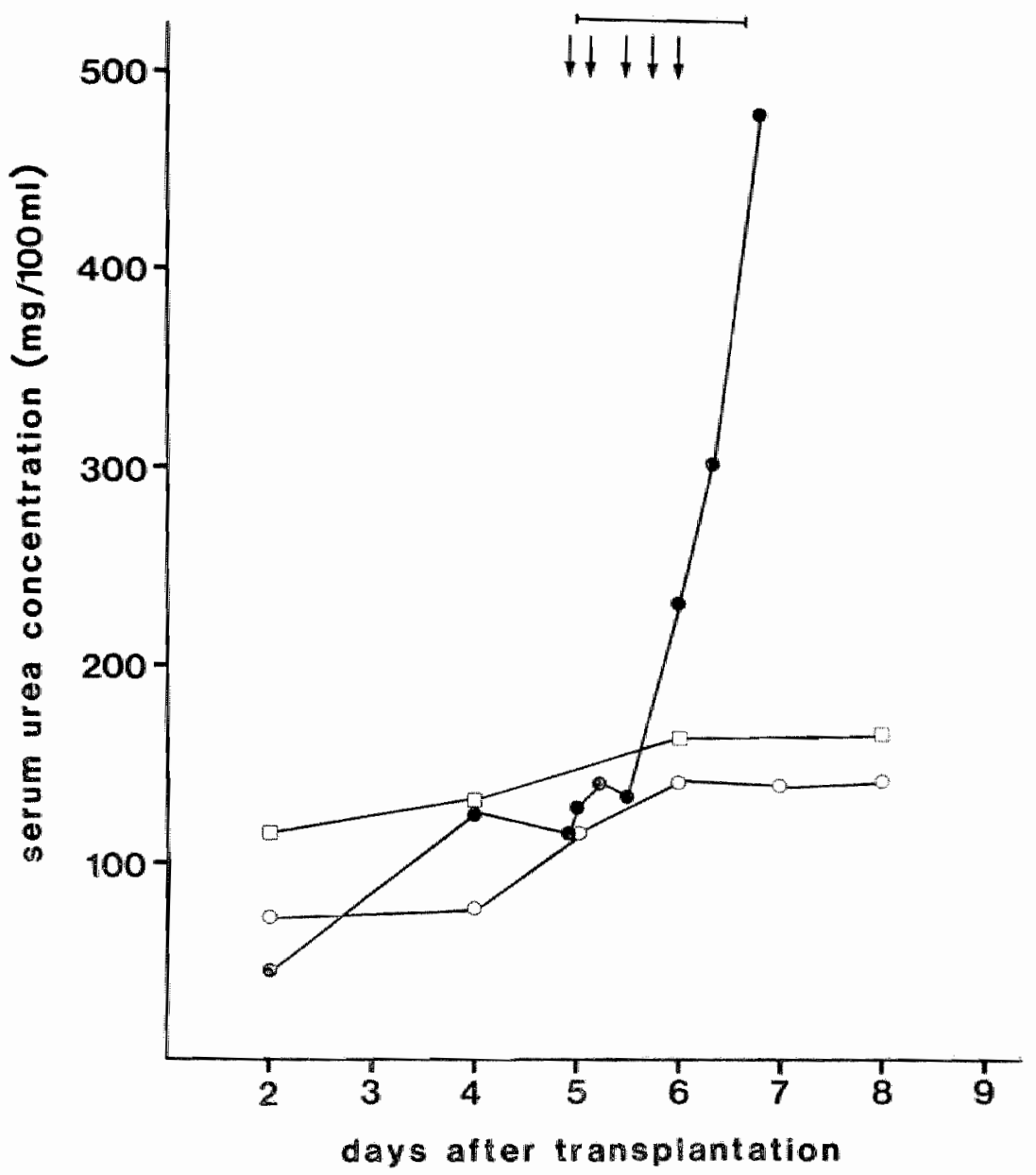

Fig. VIII.5. Effect of infusion of BN anti LEW kidney antibody on the survival of a $L E W$ kidney residing in $L E W-E$ unr. $B N$ host.

A LEW-E unr. BN hosi of a LEW kidney received 5 infusions $(1)$ of $1.0 \mathrm{ml}$ crude Y-globulin preparation isolated from BN ant $L$ LEW kidney antisera (-). Another LEW-E unr. BN host of a LEW kidney received Y-giobulins isolated by the same procedure from normal $B N$ serum by continuous infusion over a 2-day period $(-)(O)$. For comparison, the mean serum urea concentration of $16 \mathrm{LEW}-\mathrm{E}$ unr. BN hosts of LEW kidneys has been reproduced from Fig. VIII.1. (U). 
BN rats responded in a normal fashion to LEW stimulator cells in unilateral MLC. Next, LEW kidneys inserted into these rats elicited lymphocytotoxic antibody responses to donor Class II antigens and cell-mediated immune responses quantitatively identical to those elicited in controls. Finally and most importantly WISTAR kidneys grafted to LEW-E unr. BN rats elicited hemagglutinins and were rejected acutely. Thus, insertion of LEw kidneys grafted to LEW-E unr. BN rats did not 'break" the humoral responsiveness to LEW-E-associated antigens and thereby probably eliminated their capacity to reject LEW kidney grafts acutely.

Others have also observed a beneficial effect on rat renal allograft survival by pretreating recipients with platelets (22) or erythrocyte suspensions (9). Infusions of AUGUST platelets into AS rats have been shown to enhance the survival of subsequently inserted (AS $\times$ aUGUST) $F_{1}$ kidney grafts in these recipients (2). Prolongation of renal graft survival was ascribed to enhancement by undetected non-saturating amounts of anti platelet antibodies resulting in elimination of immunocompetent cells with specificity for donor Class I transplantation antigens $(10)$. The prolongation of $\mathrm{BN}$ renal allograft survival observed after infusion of $8 \times 10^{2}$ BN-E into WAG/RJ rats 14 days prior to grafting with a BN kidney was thought to be mediated by antibodies directed to erythrocyte-associated antigens (II).

Although small amounts of anti donor antiserum may suffice to induce passive enhancement of renal allografts (5) it was unlikely that antibody-mediated enhancement was operational in prolonging the survival of LEW kidneys residing in LEW-E-infused hosts for several reasons. First, by means of indirect immunofluorescence we failed to demonstrate immunoglobulin deposition in LEW kidneys residing in LEW-E unr. BN rats within 5 days post-transplantation. In addition, using a sensitive hemagglutination assay anti LEW hemagglutinins were not detected in LEW-E unr. BN rats prior to transplantation. Failure to demonstrate hemagglutinins was not due to binding of antibody eventually elicited to LEW-E in these LEW-E-infused BN hosts since the half-life of $1 \times 10^{10}$ LEW-E and $B N-E$ was identical in one month old $\mathrm{BN}$ rats (Chapter $\mathrm{V}$, Section 3 ). Second, the decrease in the cytotoxic antibody response to Class II antigens (20) and the delayed appearance of cell-mediated cytotoxic responses $(3,4)$ observed in a number of passive enhancement 
models for rat renal allografts was not observed in our model. In contrast, antibody responses to donor Class II antigens as well as T cell-mediated cytotoxicity elicited by LEW kidneys residing in LEW-E unr. and unmodified BN rats were quantitatively identical. Finally, BN rats have been shown to be relatively insensitive to induction of active enhancement ( 7 ).

The prolonged LEW renal allograft survival brought about by infusing $B N$ recipients with LEW-E appears not to be unique for this organ or the strain combination used for DA skins grafted on DA-E-infused BS recipients failed to elicit hemagglutinins in a number of instances and enjoyed a slightly enhanced survival (9). The marginal effect on skin graft survival times may be due to the prevalence of peripheral sensitization of the host by skin allografts primarily resulting in delayed hypersensitivity as compared to renal allografts sensitizing the host predominantly by the intravascular route (21). The observation that infusion of LEW rats with $1 \times 10^{7}$ $\mathrm{BN}-\mathrm{E} 7$ days prior to insertion of a (LEW $\times \mathrm{BN}) \mathrm{F}_{1}$ heart allograft caused only a marginal prolongation of graft survival (13) is not contradictory to our results since infusion of $1 \times 10^{8} \mathrm{BN}-\mathrm{E}$ into LEW rats failed to elicit specific unresponsiveness (Chapter IV, Section 2.1).

Comparison of graft histology and in vitro $\mathrm{T}$ cell-mediated cytotoxicity did not reveal quantitative differences of cellular immune responses to LEW renal grafts in LEW-E unr. and control $\mathrm{BN}$ recipients. Although we cannot rule out the possibility that the specificity of cellular immune responses was altered in LEW-E Unr. recipients of LEW kidneys this is unlikely for two reasons. First, $T$ lymphocytes from LEW-E unr. and unmodified BN hosts of LEW kidneys were equally cytotoxic to both Ia-positive Con-A-stimulated and Ia-negative PHA-stimulated LEW lymphoblasts (15). Second, cytotoxic $T$ lymphocytes from both sources could not damage target cells derived from LEW. $1 \mathrm{~N}$ rats which carry the $\mathrm{RTI}^{\mathrm{n}}$ haplotype on the LEW genetic background, excluding the involvement of lymphocyte-associated target antigens encoded by minor histocompatibility loci (I8) (Data not shown).

Most likely therefore the failure of LEW-E unr. BN rats to reject LEW kidneys acutely was due to the absence of hemagglutinating antibody. This assumption was supported by the finding that a LEW kidney residing in a LEW-E unr. BN host could be rejected acutely provided BN anti LEW kidney antibodies were passivelly 
administered from the 5th post-operative day. Although the antibodies infused were most likely to be directed in part to Class II antigens as well, these antibodies were shown not to mediate rejection of LEW kidneys residing in LEW-E unr. BN hosts. Antibodies to LEW-E-associated antigens may be needed for acute rejection of renal grafts by BN recipients to occur by acting in adjunct to antibodies to donor Class II antigens (16) and kidney-specific antigens $(8)$ to raise the susceptibility of the graft to complementmediated or antibody-dependent cell-mediated (6) effector mechanisms.

\section{Summary}

In addition to the lack of antibody responses to LEW-E-associated antigens in LEW-E unr. BN rats, these rats were shown also to be void of cytotoxic antibodies and $T$ cells to LEW target cells. The magnitude of the proliferative response of lymphocytes taken from LEW-E unr. BN rats in unilateral MLC against LEW stimulator cells was identical to that of lymphocytes obtained from unmodified BN rats.

LEW renal grafts inserted in LEW-E unr. BN rats showed a markedly prolonged survival which was specific since WISTAR renal grafts were acutely rejected by these recipients. LEW kidneys grafted to unmodified and LEW-E unr. BN rats elicited cytotoxic antibody responses to Class II antigens and cellular immune responses of identical magnitude and specificity. On the other hand, LEW renal grafts evoked hemagglutinating antibodies in unmodified $\mathrm{BN}$ rats but failed to "break" unresponsiveness to LEW-E-associated antigens in LEW-E unr. BN hosts.

These observations suggested the failure of LEW-E unr. BN rats to reject LEW renal grafts acutely to be due to the absence of antidonor Class I antibody responses in these recipients. This assumption was corroborated by two findings. First, wisTAR renal grafts elicited anti donor Class $I$ antibody responses in LEW-E unr. BN rats and were rejected acutely, and second, passive administration of BN anti LEW kidney antibodies -- including anti LEW hemagglutinins - to a LEW-E unr. BN host of a LEW kidney from day 5 post-transplantation effected acute rejection of this kidney. Thus, antibodies to LEw Class I antigens were concluded to play an obligatory role in the rejection of LEW kidney grafts by $B N$ rats. 


\section{References}

1 abbas, A. K., Corson, J. M., Carpenter, C. B., Galvanik, E. G., Merrili, J. P.s and DAMMIN, G. J. : Immunologic enhancement of rat renal allografts. II. Immunohistology of aculely rejecting and passively enhanced grafts. Am. J. Pathol. 75: 271, 1974.

2 BATChelor, I. R., WELSH, K. I., and BurGos, H. : Immunologic enhanoement. Transplant. Proc. 9: 931, 1977.

3 Biesecker, J. L., Fitch, F. W., Rowley, D. A., and Stuart, F. P.: Cellular and humoral immunity after allogeneic transplantation in the rat. III. The effect of passive antibody on cellular and humoral immunity after allogeneic renal transplantation. Transplantation 16 : 432,1973 .

4 Burgos, H., French, M. E., and Batchelor, J. R. : Humoral and cell-mediated immunity in rats with enhanced kidney allografts. Tramsplantarion $18: 328,1974$.

5 FArre, J. W., and Morris, P. J. : Dose response studies in passive enhancement of rat renal allografts. Transplantation $15: 397,1973$.

6 Giarovor, M. R., Strom, T. B., Gribik, M., and Carpenter, C. B.: Antibody-dependent lymphocytemediated cytotoxicity (Ab-LMC), definition of the ' $\mathrm{K}$ cell' in the rat. Transplantation 22: 367, 1976 .

7 Guttmann, R. D. : In vitro correlates of nejection. II. Rat mixed Iymphocyte reactivity in vitro and cardiac allograft acute rejection, hyperacute or accelerated rejection, and prolongation by active immunizaticn. Transplantation 23:153, 1977.

8 HART, D. N. J., and FABre, J. W. : Kidney-specific alloantigen system in the rat. Characterization and role in transplantation. $J$. Exp. Med. 151: 651,1980 .

9 HESLOP, B. F., and HESLOP, H. E. : Allogeneic red blood cells fail to induce hemagglutinating antibodies or cellular alloimmunity in rats and are immunosuppressive. Transplantation $28: 144,1979$.

10 Hutchinson, I. V. : Antigen-reactive cell opsonization (ARCO) and its role in antibady-mediated immune suppression. Immunol. Rev. 49: 167,1980

11 JeEkel, J., DONGEN, J. VAN, MAJOOR, G., and HARder, F. : Enhancement of rat renal allograft with antibodies directed against erythrocyleassociated antigens (EAA). Trantsplant. Proc. 9: 969, 1977.

12 KEOWN, P. A., and DEsCAMPs, B.: Improved renal allograft survival after blood transfusion: A nonspecific erythrocyte-mediated immunoregulatory process? Lancet $I: 20,1979$.

13. Lauchart, W., Alkins, B. J., and Davies, D. A. L.: Only B lymphocyles 
induce active enhancement of rat cardiac allografts. Transplantation 29 : $259,1980$.

14 Nabholz, M., Young, H., Rijnbeek, A., Boccardo, R., David, C. S, Meo, T., Miggiano, $V_{.,}$and SCherfler, D. C. : I-region-associated determinants : expression on mitogen-stimulated lymphocytes and detection by cytotoxic T cells. Eur. J. Immunol. $5: 594,1975$.

I5 Niederhöber, J. E., Frelinger, J. A., Dine, M. S., Shoffener, P., DUGAN, E., and Shreflek, D. C. : Effects of anti La-sera on mitogenic responses. 11. Differential expression of the la marker on Phytohenagglutinin- or Concanavalin A-reactive T-cells. J. Exp. Med. 143: 372, 1976.

16 Pallo, L. C., Milford, E. L., Paradysz, J. M., and Carpenter, C. B. : Alloantigens on the endothelium of rat kidneys. Transplant. Proc., in press.

17 RASKOVA, J., and MORRISON, A. B. : A decrease in cell-mediated immunity in uremia associated with an increase in activity of suppressor cells. Am. J. Parthol. $84: 1,1976$.

18 Snek, T., Marshak-Rothstein, A., and. Wilson, D. B. : Sudies on the MHC-linked 'CT' alloantigenic systems in rats. 1. Neither an SD nor an LD gene product Immunogenetics 9: 165, 1979.

19 Soullilou, J. P., Carpenter, C. B., D’Apice, A. J. F., and Strom, T. B. : The role of non-classical, Fc receptor-associated, $\mathrm{Ag}-\mathrm{B}$ antigens (Ia) in rat allograft erhancement. J. Exp. Med. 143: 405, 1976.

20 Suthantiran, M., Catto, G. R. D., Kaldany, A., George, K., Garavor, M. R., Strom, T. B., and CARpenter, C. B. : Differential antibody responses to $\mathrm{Ag}-\mathrm{B}$ (A region) and $\mathrm{Ia}$ ( $\mathrm{B}$ region) antigens during enhancement of rat renal allografts. Transplantation $28: 4,1979$.

21 TURK, J. L. : Response of lymphocytes to antigen. Tramsplantation 5 : $952,1967$.

22 WeLSH, K. I., BURGos, H., and BATCHELOR, J. R. : The immune response to allogeneic rat platelets; Ag-B antigen in matrix form lacking la. Enr. J. Immunol 7: 267, 1977. 


\section{SUMMARY}

This thesis addresses itself to the role of alloantibodies in the rejection of renal allografts in the rat. The rat was chosen since the availability of inbred strains of rats and microchirurgical techniques allow renal transplantation to be carried out in this species in a reproducible manner. The alloantigenic systems of the rat possibly involved in renal allograft rejection have been reviewed in Chapter 11 . The rat major histocompatibility complex includes the RTI.A and RTI.B regions - which can be compared to the HLA-A,B and HLA-D loci of man - coding for Class 1 and Class II antigens respectively. Class I histocompatibility antigens reside on all nucleated cells and in the rat also on erythrocytes. Hence, by infusing BN rats with LEW-E immune responses can be elicited selectively directed to LEw Class 1 antigens. Studies were designed in such a fashion that both the effect of unresponsiveness and responsiveness in terms of antibody production to Class I antigens on renal allograft rejection could be investigated. Thus, in contrast to the approach of others who studied the role of antibodies to donor Class I antigens on renal allograft rejection in rats by passive administration of these antibodies we actively immunized prospective renal graft recipients against donor Class I antigens. Models of active immunization appear to be more pertinent to the clinical situation for patients awaiting a renal graft may have been sensitized to donor antigens by blood transfusions, pregnancies or organ grafts.

Two major problems had to be overcome in order to sensitize rat recipients of renal allografts to donor Class 1 antigens prior to transplantation. The first one was of a technical nature : although rat erythrocytes express Class $I$ antigens on their surface in the absence of Class II antigens and were therefore suitable immunogens, the erythrocytes had to be cleared of peripheral blood leukocytes. The latter possess both Class I and Class II antigens on their surface and thus might sensitize the kidney graft recipients for donor Class II antigens as well. The procedures developed for the purification of rat erythrocytes, the demonstration of the efficiency of the purification procedure - yielding erythro- 
cyte suspensions containing less than one leukocyte per $1 \times 10^{8}$ erythrocytes - and the hemagglutination assays worked out to detect antibody formation against allogeneic rat erythrocytes represent a major part of Chapter III.

The second problem derived from the fact that rat erythrocytes had been shown by several other investigators to be non-immunogenic to allogeneic recipients. LEW-E however readily elicited hemagglutinin responses in allogeneic BN recipients. In order to exclude that we were studying an unique strain combination we extended our investigations on this subject by determining immune responsiveness to allogeneic erythrocytes in a number of different rat strain combinations and an in depth analysis of the specificity of BN anti LEW-E antibodies was made. Chapter IV describes the results of these studies which showed that both IgM and IgG hemagglutinin responses could be elicited by three consecutive infusions of $1 \times 10^{8}$ LEW-E into adult $\mathrm{BN}$ rats. Antibodies to LEW-E were shown to be directed to LEW Class I antigens and in addition to a minor alloantigenic system which could not be identified on the basis of the known alloantigenic systems of the rat. Further, these studies led to the conclusion that Class I antigens presented on congenic erythrocytes are immunogenic as shown by theil capacity to elicit $\operatorname{lgM}$ alloantibodies. The production of $\operatorname{IgG}$ hemagglutinins by $\mathrm{BN}$ rats in response to LEW-E however appeared to be restricted to this rat strain; these IgG antibody responses were hypothesized to be brought about by synergy of donor Class I antigens and minor alloantigens acting together in stimulating the immune system of $\mathrm{BN}$ rats, or alternatively to be due to control by immune response gene(s) located outside the RTI gene region.

In the course of the studies on the immunogenicity of allogeneic erythrocytes it was noticed that depending on the dose of LEW-E infused and the age of the recipient, immune responses as well as unresponsiveness in terms of antibody formation could be elicited reproducibly in $\mathrm{BN}$ rats. Thus, it emerged that administration of $1 \times 10^{10}$ LEW-E to BN rats one month of age or a dose of $1 \times 10^{10}$ LEW-E/ $100 \mathrm{~g}$ recipient weight did not elicit anti LEW hemagglutinin responses. Studies on the mechanism(s) involved in the maintenance of unresponsiveness to LEW-E in these recipients are described in Chapter V. Unresponsiveness was shown to be antigen-specific 
and to be transferable to unmodified BN rats by means of T lymphocytes isolated from the spleens of LEW-E unr. BN rats. These results indicated that antigen-specific suppressor $T$ lymphocytes were involved in the maintainance of unresponsiveness to LEW-E-associated antigens in LEW-E unr. BN rats.

Next, the effect of sensitization of prospective $B N$ recipients of LEW kidneys with LEW-E was studied. Protocols were selected yielding $B N$ rats actively responding to $\mathrm{LEW}-\mathrm{E}$ with $\mathrm{IgM}$ antibody or with $\mathrm{IgG}$ antibody and $\mathrm{BN}$ rats unresponsive to LEW-E-associated antigens in terms of alloantibody production.

In Chapter VI the effect of an existing BN anti LEW-E IgM antibody response on LEW renal graft rejection is presented. Graft rejection. was observed to commence at the same time in both unmodified and $\operatorname{IgM-BN}$ hosts but proceeded more slowly in IgM-BN rats yielding slightly prolonged survival times in these hosts. Histology of LEw grafts rejected by IgM-BN hosts was markedly different from that of LEW kidneys rejected by unmodified BN rats: the vasculonecrotic lesions usually present in the latter material were absent from 5 out of 6 kidneys rejected by IgM-BN hosts. Since absence and presence of vasculonecrotic lesions was associated with the absence or presence of anti LEW-E IgG antibody responses in this experiment $\mathrm{IgG}$ antibodies to Class I antigens were tentatively concluded to mediate vasculonecrotic lesions in the graft. On the other hand, it was clear that IgG antibody to donor Class 1 antigens did not play an obligatory role in renal allograft rejection : all LEW grafts were rejected by IgM-BN recipients within 14 days after transplantation even in the absence of anti LEW IgG hemagglutinins.

The fate of $\mathrm{LEw}$ kidneys inserted into $\mathrm{IgG}-\mathrm{BN}$ recipients is the subject of Chapter VII. The onset of rejection of the renal allografts was found to be slightly accelerated compared to controls; also the survival of these grafts was slightly curtailed. Since vasculonecrotic lesions were noticed in kidneys rejected by $\mathbb{I g G - B N}$ hosts acceleration of rejection was considered to be due to a vasculitis mediated by IgG antibodies to LEW Class I antigens residing on the endothelial cells of the graft. The fact that these complement-fixing IgG antibodies failed to reject LEW kidneys in a hyperacute fashion suggested that 'help' had to be provided to the IgG' antibodies to donor Class I antigens in order to cause a vasculitis. The 'help' 
appeared not to be provided by cytotoxic T lymphocytes for in vitro assays showed the $\mathbb{T}$ lymphocyte-mediated cytotoxicity in IgC-BN hosts of LEW kidneys to be markedly reduced compared to controls when measured at the time of onset of renal allograft rejection. Which mechanism(s) constitute the "help" we do not know but improvement of renal flow a few days post-operatively is argued to be one possibility.

Chapter VIII deals with the effect of established unresponsiveness to LEW-E-associated antigens in $\mathrm{BN}$ rats on the rejection of subsequently inserted LEW renal grafts. Infusion of large doses of LEW-E into BN rats prior to transplantation did not induce detectable cellular or humoral responses to LEW Class I antigens; neither the proliferative response of lymphocytes from these recipients to LEW stimulator cells in vitro was interfered with.

Survival of LEW kidneys in LEW-E unr. BN rats was markedly enhanced. Prolongation of LEW allograft survival was specific since LEW-E unr. BN rats rejected WISTAR renal allografts acutely. Cytotoxic antibody responses to LEW Class $I 1$ antigens and the cytotoxic $T$ cell response to LEW Class I antigens were identical in LEW-E unr. and unmodified BN hosts of LEW kidneys. However, LEW kidneys did not 'break' humoral unresponsiveness to LEW-Eassociated antigens in LEW-E unr. BN hosts suggesting antibodies to these antigens to play an important role in the rejection of LEW renal allografts. This assumption was corroborated by the finding that WISTAR kidneys elicited anti WISTAR hemagglutinins in LEW-E unr. BN rats.

Taken together, the results from this study indicate antibodies to donor Class I antigens to play an obligatory role in the acute rejection of LEW renal grafts by BN recipients. IgG antibodies to donor Class I antigens appear to be most effective by mediating a necrotizing vasculitis in the graft. However, (delayed) rejection of LEW kidneys by $\operatorname{lgM}-\mathrm{BN}$ rats in the absence of $\mathrm{gg}$ antibody to donor Class I antigens suggests IgM antibodies with this specificity to be effective as well, albeit not by the induction of vasculonecrotic lesions. A role for cytotoxic $T$ cells and antibody to donor Class II antigens in delayed rejection of LEW renal grafts by $\lg \mathrm{M}-\mathrm{BN}$ rats has not been formally excluded but is unlikely since LEW kidneys inserted into LEW-E unr. BN rats enjoyed a markedly prolonged survival in spite of the fact that these host-versus-graft. responses were not influenced in these recipients. 


\section{SAMENVATTING}

Het onderzoek gepresenteerd in dit proefschrift heeft tot doel de rol op te helderen die antilichamen spelen bij de afstoting van niertransplantaten door ratten. De rat werd als proefdier gekozen ondat, dank zij het beschikbaar zijn van ingeteelde rattenstammen en mikrochirurgische technieken, in deze diersoort niertransplantaties op een reproduceerbare wijze kunnen worden verricht. De alloantigene systemen van de rat die een rol zouden kunnen spelen bij de afstoting van niertransplantaten zijn samengevat in een literatuuroverzicht (Hoofdstuk 1I). Hierin wordt o.a. beschreven dat het belangrijkste komplex van genen die koderen voor de histocompatibiliteits-antigenen ( $\mathrm{MHC}$ ) in de rat ten minste twee gebieden omvat: het RTI.A en het RTI.B gebied. Deze gebieden zijn vergelijkbaar met de HLA-A,B en HLA-D loci van de mens en koderen respektievelijk voor Klasse I en Klasse II antigenen. Klasse I histocompatibiliteits-antigenen komen voor op alle kernhoudende cellen en bij de rat ook op erythrocyten. In BN ratten kunnen dus, door LEW-E intraveneus in te spuiten, antilichamen worden opgewekt welke tegen Klasse I antigenen gericht zijn maar niet tegen Klasse 11 antigenen, daar deze niet op de erythrocyt voorkomen. Het onderzoek werd zó opgezet dat zowel het effekt van reaktiviteit als van non-reaktiviteit met betrekking tot antilichaamproduktie op de afstoting van niertransplantaten kon worden onderzocht. Dus in tegenstelling tot de benadering van anderen die de rol van antilichamen tegen donor Klasse I antigenen bij de afstoting van niertransplantaten bestudeerden door deze antilichamen passief toe te dienen hebben wij toekomstige ontvangers aktief tegen Klasse I antigenen gesensitiseerd. Modellen warin aktieve immunisatie wordt toegepast sluiten beter an op de klinische situatie waarin patienten in afwachting van een niertransplantaat gesensitiseerd kunnen worden tegen donor Klasse I antigenen door bloedtransfusies, zwangerschappen of orgaantransplantaten.

Twee belangrijke problemen moesten overwonnen worden om ontvangers van allogene niertransplantaten vóór transplantatie te kunnen sensitiseren tegen donor Klasse I antigenen. Het eerste 
was van technische aard: de erythrocyten die gebruikt werden voor immunisaties dienden geen leukocyten te bevatten aangezien deze laatsten zowel Klasse I als Klasse II antigenen op hun oppervlak hebben en derhalve de ontvangers van niertransplantaten ook tegen Klasse II antigenen zouden kumnen sensitiseren. De procedures die ontwikkeld werden voor de zuivering van ratte-erythrocyten, het aantonen van de efficiëntie van de zuiveringsprocedure die erythrocytensuspensies opleverde met minder dan 1 leukocyt per $1 \times 10^{8}$ erythrocyten - en de hemagglutinatietechnieken die werden uitgewerkt om antilichaamvorming tegen allogene ratteerythrocyten te kunnen aantonen maken een belangrijk deel uit van Hoofdstuk III.

Het tweede probleem vond haar oorzaak in het feit dat verschillende andere onderzoekers hadden aangetoond dat ratte-erythrocyten niet immunogeen waren voor allogene ontvangers. LEW-E riepen evenwel hemagglutinine-responsen op in allogene BN ontvangers. Om uit te sluiten dat een unieke kombinatie van stammen werd gebruikt breidden we ons werk op dit gebied uit door het immunologisch reaktievermogen tegen allogene erythrocyten in een aantal verschillende combinaties van rattestammen te bepalen en door de specificiteit van $B N$ anti LEW-E antilichamen nader te analyseren. Hoofdstuk IV beschrijft de resultaten van deze onderzoeken welke aantoonden dat zowel IgM als IgG hemagglutinineresponsen konden worden opgewekt door volwassen BN ratten drie maal opeenvolgend intraveneus in te spuiten met $1 \times 10^{8} \mathrm{LEW}-\mathrm{E}$. Antilichamen tegen LEW-E bleken tegen LEW Klasse I antigenen gericht te zijn en bovendien tegen een alloantigeen systeem dat niet geîndentificeerd kon worden als één van de bekende alloantigene systemen in de rat. Verder leidde dit onderzoek tot de konklusie dat Klasse $\mathrm{I}$ antigenen gepresenteerd op congene erythrocyten immunogeen zijn, zoals bleek uit hun vermogen $\operatorname{lgM}$ alloantilichamen op te wekken. De produktie van $\operatorname{lgG}$ antilichamen door BN ratten tegen LEW-E leek echter specifiek voor de BN stam; van deze IgG antilichaam-respons wordt verondersteld dat deze teweeg gebracht wordt door synergie van donor Klasse I antigenen en 'minor' alloantigenen bij gelijktijdige stimulatie van het immuunsysteem van BN ratten of, als alternatief, dat IgG antilichaamproduktie onder kontrole staat van 'immunn-respons genen' die buiten het gebied van de RT1 genen gelegen zijn. 
Tijdens het bestuderen van de immunogeniciteit van allogene erythrocyten viel op dat, afhankelijk van de hoeveelheid LEw-E die werd geïnfundeerd en van de leeftijd van de ontvanger, reproduceerbaar zowel antilichamen konden worden opgewekt alsook een onvermogen om met antilichamen te reageren. Zo werd gevonden dat toediening van $I \times 10^{10}$ LEW-E aan één maand oude BN ratten, of een hoeveelheid van $1 \times 10^{10}$ LEW-E/100 g lichaamsgewicht aan volwassen BN ontvangers, geen anti LEW hemagglutinine respons opwekte. Onderzoeken naar het mechanisme(n) betrokken bij het in stand houden van de non-reaktiviteit tegen LEW-E in deze ontvangers zijn beschreven in Hoofdstuk V. Aangetoond werd dat dit niet-reageren antigeen-specifiek was en dat het middels $T$ lymfocyten geïsoleerd uit de milten van LEW-E unr. BN ratten overdraagbaar was aan onbehandelde $\mathrm{BN}$ ratten. Deze resultaten gaven aan dat antigeen-specifieke suppressor $\mathrm{T}$ lymphocyten betrokken waren bij het in stand houden van de non-reaktiviteit tegen LEW-E-geassociëerde antigenen in LEW-E unr. BN ratten.

Vervolgens werd het effekt van sensibilisatie van toekomstige BN ontvangers van LEW nieren met LEW-E bestudeerd. Protokollen werden gekozen waarmee $\mathrm{BN}$ ratten konden worden verkregen die aktief reageerden tegen LEW-E door produktievan IgM antilichamen of $\mathrm{IgG}$ antilichamen dan wel een specifiek onvermogen vertoonden om met antilichamen tegen LEW-E te reageren.

In Hoofdstuk VI wordt het effekt van een bestaande BN anti LEW-E IgM antilichaamrespons op de afstoting van LEW niertransplantaten gepresenteerd. Gekonstateerd werd dat transplantaat-afstoting terzelfder tijd begon in onbehandelde en $\operatorname{lgM}-\mathrm{BN}$ gastheren maar dat deze langzamer verliep in IgM-BN ratten, wat in enigszins verlengde overlevingstijden in deze gastheren resulteerde. De histologie van LEW nieren welke waren afgestoten door IgM-BN gastheren verschilde wan die van LEW nieren afgestoten door onbehandelde $\mathrm{BN}$ ratten : de fibrinoide necrose van de arterièn, glomerulaire lis necrose en lokale nierschorsnecrose welke gewoonlijk aanwezig waren in het laatstgenoemde materiaal waren afwezig in 5 van de 6 nieren die werden afgestoten door $\operatorname{lgM-BN}$ gastheren. Daar de aanwezigheid en afwezigheid van deze 'vasculonecrotische laesies" in dit experiment samen viel met de aanwezigheid of afwezigheid van anti LEW-E IgG antilichamen werd gekonkludeerd dat IgG antilichamen tegen Klasse I antigenen mede de 
'vasculo-necrotische laesies' in het transplantaat teweeg brengen. Het was ook duidelijk dat IgG antilichamen tegen donor Klasse I antigenen geen vereiste zijn voor de afstoting van een allogeen niertransplantaat : alle LEW nieren werden door IgM-BN ontvangers binnen 14 dagen afgestoten ook als er geen anti LEW IgG hemagglutininen aanwezig waren.

Het lot van LEW nieren geimplanteerd in IgG-BN ontvangers is het onderwerp van Hoofdstuk VII. Het begin van de afstoting van de allogene niertransplantaten viel, in vergelijking met kontrôles, wat vroeger: ook was de overleving van deze transplantaten enigszins verkort. Omdat "vasculo-necrotische laesies' werden opgemerkt in nieren welke door IgG-BN gastheren waren afgestoten werd aangenomen dat de versnelde afstoting het gevolg was van een vasculitis veroorzaakt door IgG antilichamen tegen LEw Klasse I antigenen welke vóórkomen op de endotheliale cellen in het transplantaat. Het feit dat deze complement-bindende $\operatorname{IgG}$ antilichamen niet in staat waren tot hyperakute afstoting van LEW nieren was een aanwijzing dat "hulp" moest worden geboden aan de IgG antilichamen tegen Klasse $I$ antigenen teneinde een vasculitis te veroorzaken. 'Hulp' leek niet geboden te worden door cytotoxische $T$ lymphocyten daar uit in vitro bepalingen bleek dat de cytotoxiteit teweeg gebracht door T Jymphocyten in IgG-BN gastheren opmerkelijk verlaagd was ten opzichte van kontrôles wanneer deze gemeten werd ten tijde van het begin van de afstoting van de niertransplantaten. Welk mechanisme(n) hulp verleent is niet duidelijk maar argumenten worden aangedragen die verbetering van de doorstroming van de nier enkele dagen na transplantatie als éen der mogelijkheden aangeven.

Hoofdstuk VIll behandelt het effekt van een bestaande nonreaktiviteit tegen LEW-E-geassociëerde antigenen in $B N$ ratten op de afstoting van LEW nieren die naar deze ratten getransplanteerd werden. Infusie van grote hoeveelheden LEW-E in BN ratten vóór transplantatie riep geen aantoonbare cellulaire of humorale reakties tegen LEW Klasse I antigenen op; ook de proliferatieve respons van lymfocyten van deze ontvangers tegen LEW stimulator cellen in vitro werd er niet door beïnvloed.

De overleving van LEW nieren in LEW-E Unr. BN ratten was opmerkelijk verlengd. De verlenging van de overleving van de LEW allogene transplantaten was specifiek, aangezien LEW-E unr. BN 
ratten allogene WISTAR niertransplantaten akuut afstootten. De cytotoxische antilichaam respons tegen LEW Klasse II antigenen en de cytotoxische $T$ cel respons tegen LEw Klasse I antigenen waren identiek in LEW-E unr. en onbehandelde BN gastheren van LEW nieren. De humorale non-reaktiviteit tegen LEW-E-geassociëe, de antigenen in LEW-E unr. BN gastheren werd door LEW nieren echter niet 'doorbroken', wat aannemelijk maakte dat antilichamen tegen deze antigenen een belangrijke rol spelen in de afstoting van Lew niertransplantaten. Deze veronderstelling werd gesteund door de waarneming dat WISTAR nieren wèl anti WISTAR hemagglutininen opwekten in LEW-E unr. BN ratten.

Tesamen genomen duiden de resultaten van deze studie er op dat antilichamen tegen Klasse I antigenen van de donor een vereiste zijn voor de akute afstoting van LEW niertransplantaten door BN ontvangers. IgG antilichamen tegen donor Klasse I antigenen lijken het meest effektief te zijn in dit opzicht doordat deze een necrotiserende vasculitis in het transplantaat teweeg brengen. De (vertraagde) afstoting van LEW nieren door IgM-BN ratten in de afwezigheid van $\operatorname{IgG}$ antilichamen tegen Klasse $\mathrm{I}$ antigenen van de donor duidt er echter op dat IgM antilichamen die deze specificiteit bezitten ook effektief zijn, alhoewel niet door het veroorzaken van "vasculo-necrotische laesies". Een rol voor cytotoxische $T$ cellen en antilichamen tegen donor Klasse II antigenen in de vertraagde afstoting van LEW niertransplantaten door IgM-BN ratten werd formeel niet uitgesloten maar is onwaarschijnlijk, omdat LEW nieren welke in LEW-E unr. BN ratten geïmplanteerd werden een opmerkelijk verlengde overleving ten deel viell ondanks het feit dat deze reakties van de gastheer tegen het transplantaat in deze ontvangers niet werden beïnvloed. 